\title{
ESTUDO CEFALOMÉTRICO DAS ALTERAÇÕES DENTO-ESQUELÉTICAS DA MÁ OCLUSÃO DE CLASSE II, DIVISÃO 1 TRATADA COM O APARELHO DE HERBST E COM O APARELHO EXTRABUCAL DE TRAÇÃO OCCIPITAL
}

\section{ANA CARLA RAPHAELLI NAHÁS}

Tese apresentada à Faculdade de Odontologia de Bauru, da Universidade de São Paulo, como parte dos requisitos para obtenção do título de Doutora em Odontologia, área de Ortodontia. 


\section{ESTUDO CEFALOMÉTRICO DAS ALTERAÇÕES DENTO-ESQUELÉTICAS DA MÁ OCLUSÃO DE CLASSE II, DIVISÃO 1 TRATADA COM O APARELHO DE HERBST E COM O APARELHO EXTRABUCAL DE TRAÇÃO OCCIPITAL}

\section{ANA CARLA RAPHAELLI NAHÁS}

Tese apresentada à Faculdade de Odontologia de Bauru, da Universidade de São Paulo, como parte dos requisitos para obtenção do título de Doutora em Odontologia, área de Ortodontia.

Orientador:

Prof. Dr. José Fernando Castanha Henriques 
Nahás, Ana Carla Raphaelli

$\mathrm{N} 14 \mathrm{e}$ Estudo cefalométrico das alterações dento-esqueléticas da má oclusão de Classe II, divisão 1 tratada com o aparelho de Herbst e com o aparelho Extrabucal de tração occipital / Ana Carla Raphaelli Nahás. - Bauru, 2004.

194p.mais apêndices: il.; 29,7cm.

Tese (Doutorado) - Faculdade de Odontologia de Bauru. USP.

Orientador: Prof. Dr. José Fernando Castanha Henriques

Autorizo, exclusivamente para fins acadêmicos e científicos, a reprodução total ou parcial desta tese, por processos fotocopiadores e/ou meios eletrônicos.

Assinatura do autor(a):

Data:

Aprovado pelo Comitê de Ética em Pesquisa da FOB-USP em 28/08/2002. Aprovado pela Comissão Nacional de Ética em Pesquisa em 16/04/2003. 


\section{ANA CARLA RAPHAELLI NAHÁS}

28 de agosto de 1974

Nascimento.

São Paulo - SP

Deoclécio Nahás e

Filiação.

Maria Lúcia Raphaelli Nahás

$1993-1996$

Curso de Graduação em Odontologia - Universidade do Sagrado Coração de Jesus, USC - SP.

$1998-2000$

Curso de Pós-Graduação em Odontologia, na área de Ortodontia, em nível de Mestrado, na Faculdade de Odontologia de Bauru, da Universidade de São Paulo, USP SP.

$2001-2004$

$2002-2003$

Associações

APCD - Associação Paulista de Cirurgiões-Dentistas.

SBPqO - Sociedade Brasileira de Pesquisa Odontológica.

Curso de Pós-Graduação em Odontologia, na área de Ortodontia, em nível de Doutorado, na Faculdade de Odontologia de Bauru, da Universidade de São Paulo, USP SP.

Visiting-scholar no Departamento de Ortodontia da Faculdade de Odontologia, da Universidade de Toronto, CA.

\section{de}


"Três paixões, simples porém dominantemente fortes, governaram minha vida: a ânsia de amar, a busca pelo conhecimento, e a insuportável pena pelo sofrimento alheio."

Bertrand Russell, 1956 


\title{
Dedico este trabalho
}

\author{
Ao meu pai, Prof. Dr. Deoclécio Nahás (in memoriam), \\ meu grande mestre e minha maior fonte de inspiração da \\ Odontologia, que sempre me fez acreditar em todos os \\ benefícios desta profissão!
}

Quem me dera, um dia, poder ensinar a Odontologia com tanta Plenitude!

Quem me dera, um dia, poder ensinar a Odontologia com tanto Amor!

Quem me dera, um dia, poder ensinar a Odontologia com tanta Integridade!

\section{Pai,}

Obrigada por todos os ensinamentos transmitidos, que sempre me guiarão na estrada da vida! 
Dedico também este trabalho com meu mais profundo afeto

À minha querida mãe, Maria Lúcia, pelo amor e dedicação que sempre me dispensou.

Agradeço o constante apoio nesta conquista que, com certeza, É NOSSA!

Às minhas irmãs, Ana Lúcia e Carmen Lúcia, e aos meus cunhados, Roberto e Roberto José, pela alegria, amizade, e carinho sempre transmitidos!

E ao Cesar Augusto Magalhães Benfatti, pelo apoio, ajuda e incentivo constante em minha jornada! 


\section{Agradeço}

ao Departamento de Ortodontia,

da Faculdade de Odontologia de Bauru,

em ter me recebido com carinho e respeito. 
Meus sinceros agradecimentos aos Professores Doutores

Décio Rodrigues Martins,

José Fernando Castanha Henriques,

Guilherme dos Reis Pereira Janson,

Marcos Roberto de Freitas,

Arnaldo Pinzan e

Renato Rodrigues de Almeida,

pela maravilhosa convivência, por todos os ensinamentos e confiança em mim depositada. 


\section{Agradeço em especial,}

Ao meu estimado orientador, Prof. Dr. José Fernando Castanha Henriques, pela oportunidade e experiência que obtive, ao longo destes três anos, no desenvolvimento e amadurecimento desta pesquisa e apoio concedido à minha viagem ao exterior, tornando possível realizar parte da tese no Canadá.

Professor,

muito obrigada pela amizade, compreensão e voto de confiança!

Meu eterno reconhecimento...

Ao Prof. Dr. Guilherme dos Reis Pereira Janson,

Admiração e respeito,

participação fundamental na elaboração da análise estatística desta pesquisa,

meu sincero agradecimento. 
Minha gratidão,

Ao Departamento de Ortodontia, da Faculdade de Odontologia da Universidade de Toronto, Canadá, em especial, aos Professores Doutores

\section{Bryan D. Tompson e}

\section{Donald G. Woodside}

Pela oportunidade no enriquecimento desta pesquisa e contribuição ímpar na minha formação ortodôntica.

Muito obrigada por terem acreditado em mim e honrado-me com suas amizades!

À secretária do Centro de pesquisa Burlington Growth Centre,

Annette Nyga e

à pós-graduanda, Evangelia Chatzistavrou,

Pela ajuda constante, compreensão e carinho durante a minha permanência no Canadá. 
Agradeço ainda

Aos funcionários da Disciplina de Ortodontia: Vera Lúcia Rodrigues Purgato, Tereza Cristina Alves Camaforte Ducatti, Luiz Sérgio Vieira, Maria José dos Santos Formenti, Daniel Francisco Rascão Selmo e Thiago Braga Ferreira dos Reis pela orientação, ajuda inestimável e carinho recebido;

Aos pacientes da amostra de I.H.G pela disponibilidade e compreensão à pesquisa;

Ao Prof. Dr. Marcos Roberto de Freitas pela utilização da amostra do aparelho de Herbst, o qual apoiou o Prof. Dr. Alexandre Moro, durante o seu curso de Doutorado, a formá-la;

Ao Prof. Dr. Alexandre Moro pela eficiência e disponibilidade na orientação dos pacientes da amostra de Herbst;

Aos meus queridos amigos do Curso de Doutorado em Ortodontia Adriano Lia Mondelli, Ana Claudia de Castro Ferreira Conti, Daniela Gamba Garib Carrera, Danilo Furquim Siqueira, Fausto Silva Bramante, Karyna Martins do Valle, Karina Santana Cruz, Paulo Eduardo Guedes Carvalho e Renata Rodrigues de Almeida-Pedrin pela convivência inesquecível durante todos estes sete anos. Vocês contribuíram permanentemente na minha formação pessoal e profissional;

À amiga Daniela Gamba Garib Carrera pela ajuda na avaliação dos pacientes da amostra de IHG durante a minha permanência no exterior;

A todos os amigos de Pós-Graduação e estagiários desta Faculdade, pelos momentos gostosos que passamos e que deixarão saudades;

A todos os professores do Curso de Pós-Graduação em Ortodontia, pelos ensinamentos e experiências compartilhados;

Aos alunos do Curso de Mestrado em Ortodontia, do ano de 2001, Analu Giampietro Brandão, Angela Rita Pontes Azevedo, Celso Tinôco Cavalcanti, 
Cristina Yuka Hassunuma, Daniele Balestra Lunardi, Karina Jerônimo Rodrigues Santiago de Lima, Leniana Santos Neves, Rodrigo Hermont Cançado pela perseverança ao tratar os pacientes da amostra de IHG;

Aos alunos do Curso de Doutorado em Ortodontia, do ano de 2003, Analu Giampietro Brandão, Célia Regina Maio Pinzan Vercelino, Fabrício Pinelli Vallarelli, Fernanda Angelieri, José Eduardo Prado de Souza, Karina Maria Salvatore de Freitas, Karina Jerônimo Rodrigues Santiago de Lima, Leniana Santos Neves, Rejane Targino Soares Beltrão, Ricardo Lima Navarro, Rodrigo Hermont Cançado pela amizade constante;

Aos alunos do Curso de Mestrado em Ortodontia, do ano de 2003, Rafael Henriques, Adriana Crepaldi, Marcus Crepaldi, Darwin Vaz de Lima, Marcos Janson, Fernando Torres, Fernando Pedrin, Kelly Chiqueto, Paula Oltramari, Renata Castro, Sérgio Stelita, Alexandre Nakamura, Lívia Freitas pelo carinho recebido;

Aos colegas de profissão Leonardo Oshiro e Alexandre Nakamura pelos trabalhos em conjunto e ajuda fornecida;

A todos os funcionários da biblioteca da FOB pela solicitude, em especial Salvador, Ademir, César e Rita;

A todos os funcionários da Pós-Graduação, em especial Giane, Aurélio e Letícia, pela ajuda e dinamismo; e

Aos que participaram diretamente na elaboração deste trabalho com destreza e paciência:

Daniel Francisco Rascão Selmo pela configuração das figuras e ajuda na formatação,

Prof. Hélio Requeira da Conceição pela correção gramatical e

Prof. Roberto Pereira Lauris pela correção da análise estatística. 


\section{Agradecimentos Institucionais:}

À Faculdade de Odontologia de Bauru, da Universidade de São Paulo, representada pela sua Diretora, a Prof. Dra. Maria Fidela de Lima Navarro,

Ao Prof. Dr. José Carlos Pereira, Presidente da Comissão de Pós-Graduação da Faculdade de Odontologia de Bauru,

À Coordenação de Aperfeiçoamento de Pessoal de Nível Superior (CAPES) pela concessão dos recursos financeiros no Brasil e no Canadá.

\section{E meu especial agradecimento}

Aos meus avós maternos, Luiz e Maria, pelo amor e estímulo ao longo destes anos;

Às famílias Nahás e Raphaelli, tios, tias e primos, o meu muito obrigada pela força e carinho recebidos de todos;

À família Magalhães Benfatti pela consideração e respeito;

Às minhas eternas amigas Mariana Mondelli, Claudia Maio Gagliarde e Vanessa Mendes pela amizade sincera que cultivo a cada dia;

E a todos que, de uma forma ou outra, me ajudaram nesta caminhada.

"Em ti, Senhor, se encontram todas as minhas fontes" 


\section{SUMÁRIO}

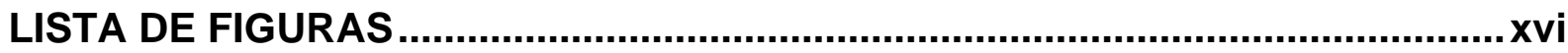

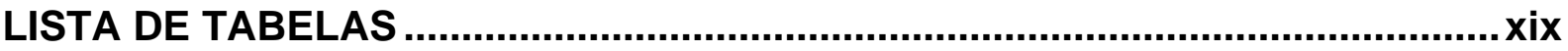

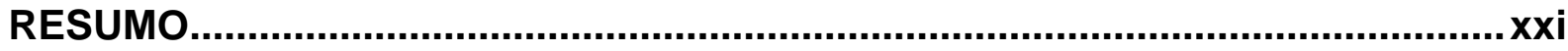

1 - INTRODUÇÃO

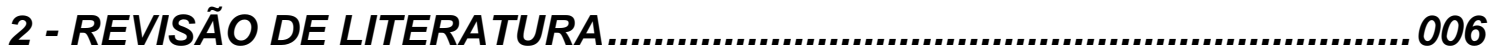

2.1 - Evolução Craniofacial das Más Oclusões de Classe II......................006

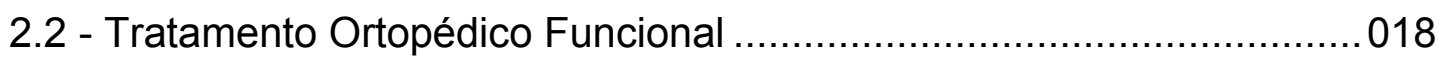

2.2.1- Aparelho de Herbst ........................................................... 018

2.2.2 - Evidências Experimentais em Animais ..................................048

2.2.2.1 - Protrusão Mandibular e Crescimento Condilar................... 049

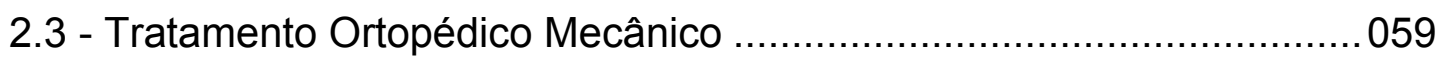

2.3.1 - Aparelho Extrabucal de Tração Occipital .................................. 059

2.4 - Comparação entre os dois Aparelhos .............................................073

3 - PROPOSIÇÃO

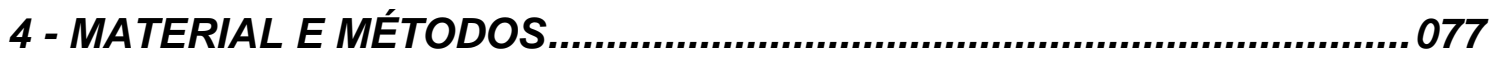

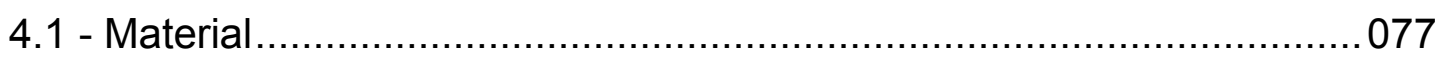

4.1 .1 - Grupos Experimentais ........................................... 077

4.1.2 - Grupos Controles ...................................................... 078

4.1.3 - Desenho dos Aparelhos e Protocolo de Tratamento .................. 080

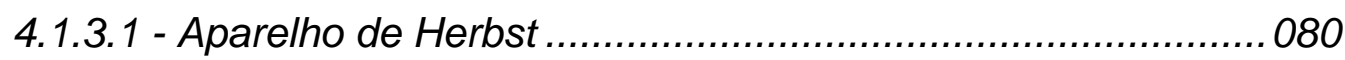

4.1.3.2 - Aparelho Extrabucal de Tração Occipital ............................ 083 
4.2 - Métodos.

085

4.2.1 - Radiografias Cefalométricas ......................................... 085

4.2.2 - Elaboração do Cefalograma............................................. 086

4.2.3 - Erro do Método ............................................................ 104

4.2.4 - Análise Estatística....................................................... 104

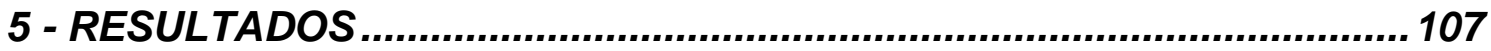

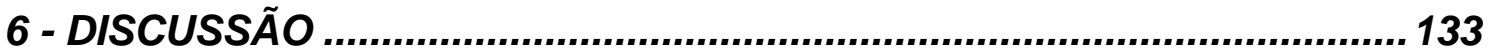

6.1 - Aspectos da Amostra ..................................................... 135

6.2 - Aspectos da Metodologia ................................................... 142

6.3 - Interpretação e Discussão dos Resultados .................................... 143

6.4 - Considerações Finais............................................................... 158

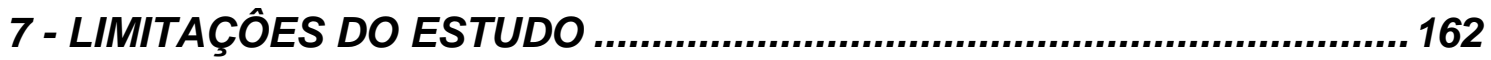

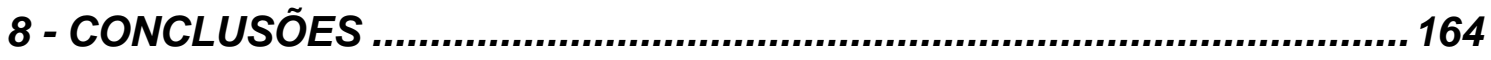

REFERÊNCIAS BIBLIOGRÁFICAS ......................................................... 168

ABSTRACT

APÊNDICE 


\section{LISTA DE FIGURAS}

FIGURA A - Aparelho Expansor tipo Hyrax; foto oclusal superior 082

FIGURA B - Aparelho de Herbst; foto intrabucal frontal 082

FIGURA C - Aparelho de Herbst; foto intrabucal lateral 083

FIGURA D - Arco facial; foto intrabucal frontal 084

FIGURA E - Aparelho Extrabucal de tração occipital; foto extrabucal lateral 085

FIGURA 1 - Delimitação das estruturas dento-esqueléticas e do perfil tegumentar 088

FIGURA 2 - Demarcação dos pontos de referência no desenho anatômico; a demarcação e enumeração destes pontos seguiram a seqüência pré-estabelecida pelo programa de análise cefalométrica DFP, Toronto, CA 091

FIGURA 3 - Linhas e planos de referência que constituíram o traçado de orientação dos cefalogramas

FIGURA 4 - Grandezas lineares e angulares na avaliação dos componentes maxilar, mandibular e relação maxilomandibular

FIGURA 5 - Grandezas lineares e angulares na avaliação do componente vertical.

FIGURA 6 - Grandezas lineares e angulares na avaliação do componente dento-alveolar superior.

FIGURA 7 - Grandezas lineares e angulares na avaliação do componente dento-alveolar inferior. 
FIGURA 8 - Grandezas lineares na avaliação da relação

Interdentária

FIGURA 9 - Grandezas lineares e angulares na avaliação do componente tegumentar

FIGURA 10 - Componente Maxilar $\left({ }^{\circ}\right)$ - S.N.A 114

FIGURA 11 - Componente Maxilar (mm) - Co-A 114

FIGURA 12 - Componente Mandibular $\left({ }^{\circ}\right)$ - S.N.B 115

FIGURA 13 - Componente Mandibular (mm) - Co-Gn 115

FIGURA 14 - Relação Maxilomandibular $\left({ }^{\circ}\right)$ - A.N.B; N.A.Pog 116

FIGURA 15 - Componente Vertical $\left(^{\circ}\right)$ - PoOr.PP; PoOr.GoMe; PoOr.PO 116

FIGURA 16 - Componente Vertical (mm) - ENA-Me; N-Me; S-Go

FIGURA 17 - Componente Dento-alveolar Superior $\left(^{\circ}\right)$ - 1.NA; 1.PP; $\underline{6} . P P$

FIGURA 18 - Componente Dento-alveolar Superior (mm) - 1-NA; 1-PP; $\underline{6}-\mathrm{PP} ; \underline{1}$-SPerpPO; $\underline{6}-\mathrm{SPerpPO}$ 118

FIGURA 19 - Componente Dento-alveolar Inferior $\left(^{\circ}\right)$ - 1.NB; 1.GoMe;

6.GoMe 118

FIGURA 20 - Componente Dento-alveolar Inferior (mm) - 1-NB; 1-GoMe; 6-GoMe; 1-SPerpPO; 6-SPerpPO 119

FIGURA 21 - Relação Interdentária (mm) - Sobressaliência; Relação Molar 119

FIGURA 22 - Componente Tegumentar $\left(^{\circ}\right)$ - Ângulo Nasolabial 120 
FIGURA 23 - Componente Tegumentar (mm) - Ls-PrnPog'; Li-PrnPog'

FIGURA 24 - Componente Maxilar $\left({ }^{\circ}\right)$ - S.N.A 125

FIGURA 25 - Componente Maxilar (mm) - Co-A 125

FIGURA 26 - Componente Mandibular $\left(^{\circ}\right)$ - S.N.B 126

FIGURA 27 - Componente Mandibular (mm) - Co-Gn 126

FIGURA 28 - Relação Maxilomandibular $\left({ }^{\circ}\right)$ - A.N.B; N.A.Pog 127

FIGURA 29 - Componente Vertical $\left({ }^{\circ}\right)$ - PoOr.PP; PoOr.GoMe; PoOr.PO 127

FIGURA 30 - Componente Vertical (mm) - ENA-Me; N-Me; S-Go 128

FIGURA 31 - Componente Dento-alveolar Superior $\left(^{\circ}\right)$ - 1.NA; 1 .PP; $\underline{6} . P P$ 128

FIGURA 32 - Componente Dento-alveolar Superior (mm) - 1-NA; 1-PP; $\underline{6}-\mathrm{PP} ; \underline{1}$-SPerpPO; $\underline{6}-\mathrm{SPerpPO}$ 129

FIGURA 33 - Componente Dento-alveolar Inferior $\left({ }^{\circ}\right)$ - 1.NB; 1.GoMe; 6.GoMe 129

FIGURA 34 - Componente Dento-alveolar Inferior (mm) - 1-NB; 1-GoMe; 6-GoMe; 1-SPerpPO; 6-SPerpPO 130

FIGURA 35 - Relação Interdentária (mm) - Sobressaliência; Relação Molar 130

FIGURA 36 - Componente Tegumentar $\left(^{\circ}\right)$ - Ângulo Nasolabial 131

FIGURA 37 - Componente Tegumentar (mm) - Ls-PrnPog'; Li-PrnPog' 131 


\section{LISTA DE TABELAS}

TABELA 1 - Cálculo do erro do método intra-examinador. Erro casual

(Dahlberg), erro sistemático (teste t pareado) e o

coeficiente de correlação de Pearson

TABELA 2 - Comparação intergrupos (Grupo 1 e Grupo Controle 1) na fase pré-tratamento, $\mathrm{T}_{1}$ (teste $\mathrm{t}$ )

TABELA 3 - Alterações do tratamento com o aparelho de Herbst (teste t pareado)

TABELA 4 - Alterações normais com o crescimento no Grupo Controle 1, em período de tempo compatível com o Grupo 1 (teste t pareado)

TABELA 5 - Comparação entre as alterações do tratamento com o aparelho de Herbst e as alterações do Grupo Controle 1 (teste $\mathrm{t}$ )

TABELA 6 - Comparação intergrupos (Grupo 2 e Grupo Controle 2) na fase pré-tratamento, $\mathrm{T}_{1}$ (teste $\mathrm{t}$ ).

TABELA 7 - Alterações do tratamento com o aparelho Extrabucal (teste t pareado)

TABELA 8 - Alterações normais com o crescimento no Grupo Controle 2, em período de tempo compatível com o Grupo 2 (teste t pareado) 123

TABELA 9 - Comparação entre as alterações do tratamento com o aparelho Extrabucal e as alterações do Grupo Controle 2 (teste $\mathrm{t}$ ). 124 
RESUMO 


\section{RESUMO}

Realizou-se um estudo cefalométrico, em telerradiografias, objetivando-se determinar os efeitos no complexo craniofacial de pacientes com más oclusões de Classe II, divisão 1 submetidos ao tratamento com o aparelho de Herbst com cantiléver e ao tratamento com o aparelho Extrabucal de tração occipital. Para tanto, utilizou-se uma amostra composta por quatro grupos, sendo dois experimentais e dois controles. Os grupos experimentais originaram-se da Faculdade de Odontologia de Bauru - USP, sendo 25 pacientes tratados com o aparelho ortopédico funcional, com a idade inicial média de 12,01 anos e 25 pacientes tratados com o aparelho ortopédico mecânico, com a idade inicial média de 10,28 anos. Os grupos controles, pareados cronologicamente aos grupos experimentais, foram compostos por pacientes não tratados ortodonticamente, oriundos do arquivo de documentações denominado Burlington Growth Centre, localizado na Faculdade de Odontologia da Universidade de Toronto.

Para cada componente dos quatro grupos, obtiveram-se as telerradiografias ao início $\left(\mathrm{T}_{1}\right)$ e ao final $\left(\mathrm{T}_{2}\right)$ do período de tratamento ou de observação, sendo traçadas manualmente e digitalizadas para um programa de cefalometria. A comparação estatística entre os grupos experimentais e seus respectivos grupos controles evidenciou que ambas as terapias corrigiram, a curto prazo, a má oclusão inicial, porém com mecanismos específicos de correção. Resumidamente, o aparelho de Herbst repercutiu em maiores alterações dentoalveolares, em decorrência da perda substancial de ancoragem dentária, mesializando os molares inferiores e vestibularizando os incisivos inferiores, enquanto que o aparelho Extrabucal apresentou um efeito ortopédico mais proeminente sobre o complexo craniofacial, alterando a tendência de deslocamento em sentido anterior da maxila.

Ambas as terapias restringiram o desenvolvimento normal no sentido vertical dos dentes póstero-superiores, contribuindo decisivamente para a correção da relação molar de Classe II e manutenção do padrão de crescimento craniofacial dos pacientes. Este achado acorda com a literatura quanto à similaridade de ação 
desses dois mecanismos terapêuticos, porém discorda quanto ao efeito inibitório dos molares superiores no sentido sagital, ou mesmo de distalização, pelo aparelho de Herbst relatado em trabalhos anteriores. 
1- INTRODUÇÃO 


\section{INTRODUÇÃO}

As más oclusões de Classe II caracterizam-se por um desequilíbrio no sentido ântero-posterior entre as bases ósseas, tendendo a um retrognatismo mandibular ${ }^{2,3,7,9,47,59,78,190}$. Esta discrepância maxilomandibular, originária de diversos fatores etiológicos, desencadeia problemas estéticos e funcionais, justificando o grande número de pacientes apresentando este quadro nas clínicas ortodônticas de todo o mundo ${ }^{74,160}$. Objetivando principalmente a correção desta complexa má oclusão, interagindo o arcabouço dentário em uma oclusão de Classe I e reduzindo a convexidade esquelética a uma arquitetura facial ideal, os profissionais contemporâneos se dispõem de um arsenal de tratamentos, destacando-se os aparelhos fixos, os aparelhos ortopédicos mecânicos e os funcionais.

Embora existam diferentes filosofias de tratamento da má oclusão de Classe II, ainda hoje pouco se sabe como os aparelhos existentes realmente funcionam, quais sistemas tissulares são influenciados e, principalmente, a magnitude e a consistência desses efeitos. Por exemplo, ainda se questiona a influência dos aparelhos ortopédicos funcionais sobre o crescimento mandibular, já que uma das maiores alterações esqueléticas nos pacientes com esta má oclusão é a retrusão mandibular ${ }^{84,100}$. O conflito entre opiniões quanto à real influência da matriz funcional ou do controle preponderante genético sobre o crescimento craniofacial é um dos fatores que estimulam a realização incansável de novos estudos, envolvendo variados tipos de aparelhos.

Apesar da diversidade, os aparelhos funcionais são similares entre si quanto ao seu modo de ação, promovendo uma alteração postural na mandíbula, posicionando-a anteriormente. Exemplificando esta categoria, enquadra-se o aparelho de Herbst, desenvolvido inicialmente por Emil Herbst ${ }^{76}$, nos primórdios do século passado, e reintroduzido por Hans Pancherz ${ }^{124}$, em 1979, caracterizando-se por um mecanismo telescópico bilateral com pistão e tubo fixado no arco dentário superior e no inferior ${ }^{93}$. Algumas vantagens são inerentes a esse aparelho como: independe da cooperação do paciente; mínima interferência com a fala e com a estética; facilidade de confecção, ativação e aceitação do paciente. O aparelho de 
Herbst, quanto à sua adaptação à cavidade bucal, pode ser bandado ou colado nos arcos dentários, podendo ser ou não associado aos fios ortodônticos. Como não há partes removíveis nesse aparelho, o fator cooperação do paciente não se torna um problema, repercutindo numa previsibilidade maior do tempo de tratamento e da obtenção de resultados ${ }^{25,114,116}$.

Uma outra questão relevante é se as alterações observadas com os aparelhos funcionais são específicas a esta modalidade terapêutica ou se outro tratamento ortodôntico é capaz de promover efeitos semelhantes. Por exemplo, os incrementos verificados no crescimento mandibular em pacientes com más oclusões de Classes II, utilizando aparelhos ortopédicos funcionais, são comparáveis aos observados com a utilização de forças extrabucais? O sistema de forças, em sentido posterior e superior, aplicado no complexo maxilar bem como nos molares superiores pelo aparelho de Herbst é comparável ao do aparelho Extrabucal de tração occipital $^{127,130,134,138}$ ? O casquete de Interlandi, difundido entre os clínicos como I.H.G., exemplifica esta categoria de forças extrabucais, classificando-se dentro da ortopedia mecânica.

Estas observações são fundamentais, pois questionam se distintas terapias provocam efeitos característicos e próprios, ou se diferentes modalidades de tratamento afetam o crescimento facial de maneira semelhante. Dependendo de qual destas afirmações seja substanciada, podem-se estabelecer os critérios que determinam a instituição de um ou de outro tratamento, pois se cada aparelho provoca efeitos característicos e individuais, a escolha da terapia a ser utilizada pode estar relacionada ao padrão craniofacial de cada paciente e não às preferências pessoais do clínico. Sabe-se que o sucesso do tratamento depende do preciso diagnóstico e apropriada indicação terapêutica ${ }^{72}$.

Em função de todos os fatores discorridos anteriormente que ainda estimulam assíduos debates, corroborando com divergências ou concordâncias de opiniões dentro da Ortopedia Funcional e Mecânica dos maxilares, propõe-se avaliar a influência dos tratamentos convencionais com o aparelho de Herbst e com o aparelho Extrabucal de tração occipital no complexo craniofacial, de pacientes com más oclusões de Classe II divisão 1 de Angle, em fase de crescimento. O diminuto 
número de trabalhos que envolvem as duas formas de tratamento, confrontando as alterações decorrentes de seus diferentes princípios biomecânicos, vem a ser enriquecido com o atual estudo, contribuindo para um melhor discernimento terapêutico. 
2- REVISÃO DE LITERATURA 


\section{REVISÃO DE LITERATURA}

Em função de uma miríade de trabalhos publicados, abrangendo diversas modalidades de tratamento da má oclusão de Classe II de Angle, a atual revisão de literatura se concentrará em aspectos pertinentes ao assunto desta pesquisa, de maneira simples, específica e de caráter didático, para que o leitor se direcione e compreenda o objetivo primordial de tal estudo.

\subsection{Evolução Craniofacial das Más Oclusões de Classe II}

O entendimento dos eventos inerentes ao crescimento e desenvolvimento craniofacial proporciona a correção ortodôntica das más oclusões, em função da observação dos locais e períodos em que se desencadeiam. Um diagnóstico preciso, um planejamento adequado e um tratamento eficiente são requisitos fundamentais para o êxito terapêutico e encontram-se altamente dependentes dos conhecimentos sobre as inúmeras alterações dento-esqueléticas que ocorrem durante os diferentes períodos de crescimento.

O estudo do crescimento e desenvolvimento craniofacial obteve um grande impulso com o advento da cefalometria, tornando possível aos pesquisadores a condução de estudos longitudinais. Trabalhos clássicos surgiram, como os de BJÖRK $^{20,21}$ e BJÖRK; SKIELLER ${ }^{22,23}$ que, por meio de implantes metálicos, pesquisaram exaustivamente o crescimento craniofacial. As pesquisas em torno das alterações cefalométricas da oclusão normal foram crescendo desde então, porém o padrão de crescimento anormal, na presença da má oclusão, não recebeu a mesma atenção. A dificuldade se deu ao fato de que os indivíduos, com más oclusões de Classe II, divisão 1, por exemplo, quando se apresentam aos ortodontistas prosseguem para o tratamento, tornando difícil a obtenção de documentações por um período razoável de tempo. Adicionalmente, a coletânia longitudinal desses dados não é simples, uma vez que esses pacientes seriam seguidos apenas para o propósito de pesquisa. 
Mesmo com a dificuldade em se obter amostras de más oclusões não submetidas ao tratamento ortodôntico, incessantes pesquisas científicas ainda são elaboradas com o intuito de caracterizá-las e de verificar a eficácia de diversos tratamentos, utilizando-as como controles aos pacientes experimentais. Essa repercussão se dá ao fato de que a má oclusão de Classe II está se tornando cada vez mais freqüente na população e, principalmente, desafiante aos clínicos.

Compulsando a literatura, esta secção visa a abordar alguns trabalhos que estudaram e descreveram as características e o comportamento craniofacial longitudinal de pacientes que apresentavam más oclusões de Classe II, não tratados com a ortodontia e ortopedia funcional, que compuseram unicamente ou não as amostras desses estudos.

RIEDEL $^{159}$, em 1952, estudou as relações da maxila e da mandíbula com a base do crânio e a relação maxilomandibular. A amostra selecionada foi constituída de 52 adolescentes e adultos (18 anos a 36 anos de idade) e 24 crianças ( 7 anos a 11 anos de idade) que apresentavam oclusões normais; 38 integrantes com más oclusões de Classe II, divisão 1 de Angle, 10 com más oclusões de Classe II, divisão 2 e 9 com más oclusões de Classe III. Grandezas cefalométricas angulares e lineares foram obtidas a partir das telerradiografias. A posição relativa ânteroposterior da maxila em relação à base do crânio foi medida pelo ângulo entre a linha Sela-Násio e o ponto A (S.N.A). Nenhuma diferença significante existiu entre os pacientes apresentando oclusões normais e más oclusões dentárias. Evidenciou-se uma tendência da maxila em se tornar mais protruída com o crescimento, ao se comparar os adolescentes com os pacientes adultos. Mediu-se a posição relativa ântero-posterior da mandíbula em relação à base do crânio pelo ângulo Sela-Násio ao ponto B (S.N.B). Verificou-se uma retrusão mandibular nas más oclusões de Classe II, divisão 1 de Angle, ao se comparar com as oclusões normais, tornando-se esse osso menos retruído com o crescimento. Diagnosticou-se a relação maxilomandibular, subtraindo-se o ângulo S.N.B do ângulo S.N.A, onde em oclusões normais, se mostrou ser de aproximadamente $2^{\circ}$. A inclinação do incisivo superior com a base do crânio não se diferenciou entre os pacientes com oclusões normais e más oclusões de Classe II, divisão 1; entretanto, evidenciou-se uma protrusão dos dentes ântero-superiores em relação ao plano facial nas classes II. 
$\mathrm{KLOEHN}^{88}$, em 1953, discorreu brilhantemente sobre os períodos de tratamento das más oclusões, bem como a sua real influência sobre o crescimento ósseo pré-determinado geneticamente. Analisando-se a má oclusão de Classe II, observou um relacionamento mesial dos dentes superiores, ao qual coloca esses elementos dentários num relacionamento funcional anormal, contribuindo para uma deformidade facial. Constatou, também, que a mandíbula, às vezes, se mostra bem desenvolvida, porém com uma discrepância no relacionamento de outros ossos faciais ou cranianos, a que é conectada, não podendo ser modificada pelos aparelhos. Alegou que os recursos terapêuticos disponíveis para a correção das más oclusões de Classe II não aumentariam o crescimento mandibular, excedendo a sua velocidade de crescimento normal, nem alterariam o seu padrão. Pelas análises efetuadas em casos finalizados, foi a movimentação dos dentes inferiores que compensou a discrepância esquelética, protruindo e mesializando os mesmos de modo expressivo. Concluiu-se que a filosofia do tratamento na dentadura mista restringe-se ao crescimento ósseo alveolar e erupção dentária, produzindo, desse modo, uma oclusão estável e que o melhor período para se tratar, bem como o melhor tratamento, estão intimamente relacionados à individualização de cada caso, não seguindo cegamente regras gerais.

Objetivando a determinação dos efeitos de vários procedimentos terapêuticos sobre as estruturas dentofaciais, RICKETTS ${ }^{155}$, em 1960, incluiu na sua amostra grupos controles, sem intervenção ortodôntica, para uma comparação direta com os casos tratados ortodonticamente. Baseado em análises cefalométricas, provenientes de radiografias obtidas longitudinalmente (com a idade inicial média de 8,1 anos, por três anos de acompanhamento) verificou que, nos 24 pacientes com más oclusões de Classe II, divisão 1 não intervindos, o plano mandibular diminuiu suavemente $\left(-0,5^{\circ}\right)$; o plano palatino permaneceu constante; o ponto A movimentou suavemente para a anterior; os incisivos superiores movimentaram para anterior; a convexidade facial melhorou (devido ao crescimento mandibular, pois a maxila mostrou uma tendência em crescer em sentido anterior, juntamente com a erupção dos incisivos superiores); os incisivos inferiores erupcionaram e retruíram em relação à sínfise mentoniana; os molares inferiores erupcionaram $(1,5 \mathrm{~mm})$ e mesializaram $(0,1 \mathrm{~mm})$; e os molares superiores também mesializaram $(2,0 \mathrm{~mm})$. O autor enfatiza a 
importância em se analisar, em estudos científicos, pacientes com más oclusões em crescimento, sem nenhuma intervenção ortodôntica ou mesmo ortopédica, no afã de se constatarem os benefícios das diversas modalidades terapêuticas.

Realizou-se um estudo radiográfico longitudinal com a implantação de pinos metálicos intra-ósseos na mandíbula (pinos de tântalo), em 1963, por BJÖRK $^{20}$, propiciando a obtenção de pontos fixos de orientação. A amostra compreendeu 45 jovens dinamarqueses do gênero masculino, com diferentes tipos de más oclusões, dos 5 aos 22 anos de idade, objetivando-se analisar o comportamento do osso mandibular com o passar dos anos. Fundamentado nos dados obtidos, pela técnica de sobreposição dos traçados, realizada anualmente, houve a ocorrência de um crescimento perióstico acentuado na porção inferior da sínfise durante a adolescência (principalmente nos casos com crescimento condilar no sentido vertical); a direção do crescimento condilar apresentou uma variação interindividual, porém sendo distribuída simetricamente (crescimento na direção vertical em alguns casos, enquanto que em outros, na direção horizontal); quando do crescimento condilar no sentido vertical, o ângulo goníaco diminuía e todos os dentes inferiores erupcionavam em sentido anterior e, quando do crescimento no sentido horizontal, o ângulo goníaco aumentava e os dentes ântero-inferiores erupcionavam em sentido posterior. Adicionalmente, salientou marcantes diferenças quanto à velocidade de crescimento condilar entre pacientes em fases anterior à pubescência e durante esse período. Em fases mais precoces, o côndilo apresentou um crescimento de 3mm/ano, decrescendo até atingir, em média, 1,5mm/ano, por volta dos 11,7 anos, enquanto que, em fases mais avançadas, o côndilo apresentou um crescimento condilar de $5 \mathrm{~mm} / \mathrm{ano}$ aos 14,5 anos.

MARSCHNER; HARRIS ${ }^{97}$, em 1966, mostraram-se confusos quanto à real possibilidade de estimular ou não o crescimento mandibular, em seu potencial máximo, com a utilização de aparelhos ortopédicos. Para tanto, com o objetivo de comparar o crescimento mandibular em pacientes com más oclusões de Classe II não tratados com aqueles submetidos às terapias ortopédicas, selecionaram 23 pacientes, do gênero masculino, entre 5 e 13 anos, para o grupo controle com documentações anuais, e 12 meninos, tratados com o aparelho Ativador de Andresen, entre 9 e 12 anos de idade, para o grupo experimental. Antes da 
apresentação dos resultados obtidos, os autores relembraram aos leitores que os grupos componentes da amostra não puderam ser totalmente pareados, devendo ser cautelosos nas interpretações. Constataram que, com o emprego do aparelho ortopédico, houve uma aceleração na velocidade de crescimento mandibular, ao observarem que, nos pacientes com más oclusões não tratados ortopedicamente, o aumento no comprimento mandibular efetivo não foi tão expressivo. Os autores discutiram ser esta resposta possível de ser influenciada pelo potencial genético de crescimento de cada paciente.

Em 1970, ODEGAARD ${ }^{121}$ estudou, cefalometricamente, com o auxílio de implantes metálicos, o comportamento longitudinal do crescimento condilar em 25 pacientes, sendo 13 do gênero masculino e 12 do feminino, que apresentavam todos os tipos de más oclusões. Mediante as observações efetuadas, a amostra apresentou uma tendência facial retrognática e uma forte correlação do crescimento condilar com o ângulo goníaco. O ângulo goníaco, quando agudo, por exemplo, associava-se a um crescimento mandibular direcionado mais no sentido vertical e anterior. Verificou-se que a direção do crescimento condilar não é dependente das variáveis cefalométricas S.N.B, S.N.Pog, N.S.Ba, SN.GoMe, pois estas determinam a relação da mandíbula com a anatomia craniana. Aconselhou-se realizar a predição do crescimento mandibular baseada na morfologia mandibular e não na posição da mandíbula em relação ao crânio.

Com o propósito de estudar e descrever as características esqueléticas associadas à má oclusão de Classe II, divisão 1 dentária, clinicamente caracterizada por uma posição posterior aparente dos primeiros molares permanentes inferiores e incisivos centrais superiores protruídos, ROTHSTEIN ${ }^{163}$, em 1971, examinou 335 telerradiografias de jovens com idades esqueléticas de 10, 12 e 14 anos, equivalentes às idades cronológicas entre 8 e 15 anos. Verificou que as associações esqueléticas, em casos de protrusão dentária superior, geralmente inlcuem: a) um maior comprimento da base craniana anterior com o ângulo da base do crânio obtuso; b) uma maxila grande com o complexo orbitomalar mais anteriormente localizado; e c) um plano palatino inclinado no sentido anti-horário. Verificou-se, adicionalmente, que o crescimento geral da face é direcionado mais para a anterior do que para a inferior. 
Seguindo a mesma metodologia de análise com pinos intra-ósseos, BJÖRK; SKIELLER ${ }^{22}$, em 1972, estudaram longitudinalmente por seis anos o comportamento do osso maxilar e do mandibular, além das estruturas dentárias, de nove meninas e 12 meninos apresentando diversos tipos de más oclusões. Perante os achados, observaram que a mandíbula e a maxila, na maioria dos pacientes, sofreram uma rotação no sentido anti-horário, caracterizando o desenvolvimento facial com uma rotação no sentido anterior. O plano palatino mostrou-se estável, independente da direção e magnitude da rotação maxilar. Confirmaram-se algumas correlações entre certas mensurações, como, por exemplo: alta correlação entre a rotação mandibular, o ângulo goníaco e a intensidade e direção do crescimento condilar; correlação do plano oclusal com a rotação das duas bases apicais; e correlação do aumento da sobressaliência durante o crescimento com grande inclinação em sentido anterior dos molares superiores. Entretanto, não houve correlação dos incisivos superiores e inferiores com a rotação de ambos os maxilares, refletindo a grande influência funcional. Evidenciou-se uma maior correlação entre as alterações nos maxilares e a direção de erupção dos incisivos e molares superiores, do que com os incisivos e molares inferiores.

Cento e nove casos com más oclusões de Classe II, divisão 1 , foram comparados cefalometricamente com 40 casos com oclusões normais por HITCHCOCK ${ }^{78}$, em 1973. O grupo com más oclusões foi composto por 57 componentes do gênero feminino e 52 do masculino, com a idade variando de 7 a 28 anos, obtendo-se a média de 13 anos. Os resultados revelaram que o ângulo S.N.A não se mostrou significantemente diferente entre os grupos, enfatizando ser a Classe Il caracterizada, na maior parte dos casos, pela retrusão mandibular. As mensurações que se seguem mostraram diferenças estatisticamente significantes entre os grupos: na Classe II, o ângulo S.N.B se mostrou menor; o ângulo A.N.B, o eixo $\mathrm{Y}$ de crescimento e a sobressaliência se mostraram maiores. Adicionalmente, se verificou que existe uma correlação entre as mensurações SN.PO e SN com o plano facial e que não existe uma correlação entre SN.PO e SN.PM em más oclusões e oclusões normais. O autor concluiu que se obtém o sucesso no tratamento por modificar os dentes superiores e se possível o padrão esquelético, especificamente a mandíbula. 
A má oclusão de Classe II foi dividida em grupos por MOYERS; RIOLO; GUIRE; WAINRIGHT; BOOKSTEIN ${ }^{118}$, em 1980, definindo seis subtipos que foram denominados de A, B, C, D, E e F, baseados em variáveis no sentido horizontal.
A. Protrusão dentária superior (pseudo Classe II);
B. Protrusão maxilar;
C. Maxila e mandíbula retrognatas com dupla protrusão dentária;
D. Maxila e mandíbula retrognatas com protrusão dentária superior;
E. Protrusão da maxila com dupla protrusão dentária, e
F. Retrognatismo mandibular.

O tipo $\mathrm{F}$ foi o mais freqüente na amostra. Verificaram-se, ainda, cinco tipos quanto às variáveis no sentido vertical, possibilitando, desta forma, a identificação de quinze combinações entre os tipos horizontais e verticais, com características distintas. Esse estudo baseou-se em telerradiografias de 57 norte-americanos que apresentavam a má oclusão de Classe II. Os autores enfatizaram a importância em se delinear o tipo de Classe II que o paciente apresenta para se indicar, com precisão, o tratamento necessário.

Acreditando que a escolha do tratamento deve estar em função do problema individual e não da preferência do profissional, McNAMARA JÚNIOR ${ }^{100}$, em 1981, examinou uma população com má oclusão de Classe II com o objetivo de determinar a natureza e a freqüência com que determinados componentes dentoesqueléticos aparecem nesta má oclusão. Radiografias em norma lateral de 277 crianças, 153 do gênero masculino e 124 do feminino, com uma idade média de nove anos, foram avaliadas. De modo geral, verificaram que, na maioria dos casos, a mandíbula apresentava-se numa posição retrusiva, a maxila e os dentes ânterosuperiores mostravam-se de modo variável e o componente vertical, apenas na metade dos casos, visto pelo AFAl e pelo plano mandibular, mostrou-se excessivo. Baseado na sua revisão de literatura e nos resultados alcançados, o autor conclui que a retrusão da mandíbula é a característica mais comum nesta má oclusão e que a Classe II não se mostra de uma única forma e sim como resultado de numerosas combinações dos componentes esqueléticos e dentários. O autor sugere tratamentos que alterem a quantidade e a direção do crescimento mandibular, como sendo mais 
apropriados na maior parte dos casos, do que aqueles que restrigem o desenvolvimento maxilar.

Em 1983, ANDERSON; POPOVICH ${ }^{2,3}$ conduziram dois estudos cefalométricos de caráter longitudinal em telerradiografias de crianças e jovens caucasianos, não tratados ortodonticamente, provenientes do arquivo Burlington Growth Centre, Universidade de Toronto. No primeiro, os autores concentraram-se cientificamente em humanos que apresentavam o ângulo da base do crânio aumentado (N.S.Ba), no afã de se verificar alguma relação desta característica em pacientes com tendência à má oclusão de Classe II de Angle. Utilizaram-se radiografias aos 4, 8, 12 e 16 anos. Mediante os resultados obtidos, verificaram que as crianças, com o ângulo da base do crânio mais aberto, apresentavam a má oclusão de Classe II 45\% mais freqüentes. Os autores alegaram que a posição posterior do côndilo mandibular, como resultado da flexão aumentada da base craniana, é um dos muitos fatores que podem estar envolvidos com a caracterização da má oclusão de Classe II. No segundo estudo, propuseram investigar a posição relativa ântero-posterior da maxila e da mandíbula em relação à base do crânio em uma amostra de 117 pacientes do gênero masculino e 99 pacientes do gênero feminino. Setenta por cento possuíam a má oclusão de Classe I de Angle (148 indivíduos) e 30\%, a Classe II (68 indivíduos). A má oclusão de Classe II compreendeu 37 pacientes do gênero masculino e 31 do gênero feminino. Utilizaramse radiografias aos 8, 12 e 16 anos de idade. Observaram que, nas más oclusões de Classe II, a maxila e a mandíbula apresentavam-se posicionadas mais para posterior em relação ao crânio, com valores mais pronunciados para a mandíbula, do que nas más oclusões de Classe I. Resumidamente, os autores concluíram que os pacientes com más oclusões de Classe II de Angle mostram uma posição mais posterior das bases apicais em relação ao crânio (especialmente a mandíbula) e uma maior abertura do ângulo da base craniana. Esta abertura é sugerida como resultado da própria posição relativa mais retrusiva da mandíbula em relação à maxila.

Nesse mesmo ano, BJÖRK; SKIELLER ${ }^{23}$ trouxeram à luz do conhecimento os eventos mandibulares que ocorreram na face durante o seu crescimento e desenvolvimento, estudados por um período de 25 anos. A associação da análise cefalométrica com implantes metálicos permitiu constatar, em pacientes 
apresentando oclusões normais e más oclusões, composições variadas de rotações mandibulares. O corpo mandibular normalmente rotaciona para a anterior, com relação à base craniana, durante o crescimento. Verificou-se também que a posição e inclinação dos incisivos inferiores variam de acordo com o padrão de crescimento individual.

Também no ano de 1983, WHITE ${ }^{201}$ examinou em telerradiografias uma amostra de 34 pacientes, não tratados, que apresentavam uma relação molar de plano terminal reto na dentadura mista (idade inicial média de 8,3 anos). Acompanhou estes pacientes até a fase final de dentadura mista e início da dentadura permanente (idade final média de 13,2 anos), onde se pôde observar, nesse período, o alcance da relação molar de Classe I em 24 pacientes, relação molar de Classe II em três e sete pacientes que ainda permaneceram na relação molar de plano terminal reto. Nos dez pacientes, onde os molares não foram ajustados idealmente, verificou-se um deslocamento tardio no sentido mesial de meia cúspide dos molares inferiores em média de $1 \mathrm{~mm}$, contrapondo-se com os molares superiores num movimento mesial médio de $2,3 \mathrm{~mm}$. Constatou que a mandíbula cresceu mais em relação à maxila, em média de $1,6 \mathrm{~mm}$, no grupo que alcançou a relação molar. Nesse estudo, o padrão de crescimento mandibular diferencial provou ser um fator muito mais significante no processo de ajuste da relação molar do que a própria mesialização dos molares inferiores. O autor sugere mais pesquisas sobre o fato de o crescimento ser ou não a causa mais próxima da mudança oclusal e alerta o clínico quanto às conseqüências morfológicas provenientes do crescimento craniofacial no desenvolvimento da má oclusão e seu subseqüente tratamento.

O comportamento do crescimento craniofacial de 20 jovens do gênero masculino com oclusões normais foi comparado cefalometricamente com o de 20 jovens, também do gênero masculino, apresentando más oclusões de Classe II, divisões 1 e 2, por BUSCHANG; TANGUAY; TURKEWICZ; DEMIRJIAN; La PALME ${ }^{31}$, em 1986. Utilizaram-se séries completas de telerradiografias, obtidas aos $11,12,13$ e 14 anos de idade. Os resultados mostraram que o plano palatino não mostrou um padrão de crescimento significante ou qualquer alteração, mantendo constante seu valor médio durante os quatro anos de pesquisa. Houve uma similaridade entre os grupos para $80 \%$ das medidas avaliadas. Sete das nove 
medidas lineares e cinco das seis angulares não resultaram em diferenças estatísticas, o que levou os autores a sugerirem que os valores padrão das grandezas cefalométricas poderiam ser aplicados para ambos os grupos, bem como a amostra controle dos estudos do tratamento da má oclusão de Classe II poderia ser constituída de pacientes com oclusões normais. Ressaltaram, ainda, que a taxa de avanço mandibular com a idade e a diminuição do ângulo A.N.B são semelhantes, tendendo à retificação do perfil e que a diferença entre a oclusão normal e a má oclusão de Classe II repousa no tamanho mandibular, caracteristicamente menor no último grupo, e na maior discrepância ântero-posterior encontrada em pacientes com Classe II.

Em um estudo dedicado à avaliação das alterações dentofaciais da má oclusão de Classe II, divisão 1 sem tratamento, CARTER ${ }^{32}$, em 1987, selecionou 30 indivíduos, sendo 15 componentes do gênero masculino e 15 do feminino. A primeira radiografia foi obtida entre 10 e 14 anos e a segunda de quatro a sete anos mais tarde, sem ultrapassar a idade de 20 anos. Os resultados cefalométricos confirmaram a manutenção da relação desarmônica entre as bases apicais durante o período de observação. O gênero masculino apresentou um aumento do comprimento mandibular três vezes maior em relação ao feminino e um crescimento mandibular mais expressivo, o que fez com que o ângulo A.N.B diminuísse em $1^{\circ}$ neste grupo, durante o período observado que foi de cinco anos. Mediante estes dados, o autor verificou que o período de observação incluiu o pico de crescimento pubescente para o gênero masculino, associando ao fato de que o crescimento continua por mais tempo neste gênero. Por sua vez, o gênero feminino apresentou um comportamento de crescimento mais vertical, provavelmente pelo menor crescimento na altura do ramo, embora ambos os gêneros tenham demonstrado uma tendência de fechamento do plano mandibular. A altura facial ântero-inferior aumentou em ambos os gêneros. Observou também uma pequena tendência, no gênero masculino, de redução da sobressaliência; entretanto, a inclinação dos incisivos superiores e inferiores tendeu a se manter com o crescimento, com ligeira vestibularização dos inferiores para o gênero feminino. A extrusão ocorreu para os molares e para os incisivos, sendo que, no arco superior, foram os molares que expressaram maior extrusão, e no inferior, foram os incisivos. Os molares, em geral, mesializaram durante o crescimento, como indicado pelas medidas em relação à linha SPerp. 
Mencionou-se que a variação individual se fez presente no estudo, não podendo nunca descartá-la em estudo cefalométricos.

Nesse mesmo ano, KERR; HIRST ${ }^{87}$ realizaram um estudo cefalométrico longitudinal, com radiografias em norma lateral aos 5, 10 e 15 anos de idade, de 85 jovens que apresentavam oclusões normais e más oclusões de Classe I e II. Os resultados deste estudo evidenciaram que as características craniofaciais dos indivíduos com oclusões normais e más oclusões de Classe II tornaram-se mais definidas com o passar da idade. Adicionalmente, com a obtenção dos dados provenientes das três radiografias, permitiu-se afirmar que o ângulo da base craniana provou ser o melhor diferenciador entre os grupos, com o valor desta mensuração aos cinco anos sendo uma ferramenta acurada de previsibilidade do tipo oclusal aos 15 anos, em 73\% dos pacientes. Comparando-se pacientes com oclusões normais e más oclusões de Classe II, o ângulo da base do crânio apresentou-se maior nestes últimos pacientes.

Em 1988, BUSCHANG; TANGUAY; DEMIRJIAN; La PALME; TURKEWICZ ${ }^{30}$ propuseram investigar a velocidade e a direção de crescimento mandibular de pacientes com oclusões normais e de pacientes com más oclusões de Classe II, divisão 1, dos 6 aos 15 anos de idade. Um total de 42 pacientes compôs o grupo com más oclusões, e um total de 71 pacientes compôs o grupo com oclusões normais. Uma diferença pequena, porém significante, na velocidade de crescimento, foi observada entre os grupos, sendo menor em pacientes com más oclusões em relação aos pacientes com oclusões normais. Verificou-se nos pacientes com más oclusões uma tendência de direção de crescimento orientada mais verticalmente que nos pacientes com oclusões normais, porém não estatisticamente significante. Adicionalmente, observou-se que a direção de crescimento, sendo ela no sentido horizontal ou vertical, tornou-se mais acentuada com o tempo. Por exemplo, pacientes com más oclusões de Classe II e com a direção de crescimento vertical tenderam a aumentar a discrepância ântero-posterior quando comparados com pacientes que possuíam uma direção de crescimento horizontal, sendo que estes últimos obtiveram uma resposta mais satisfatória com o tratamento. 
Com o propósito de verificar a existência de alguma relação entre a direção de crescimento mandibular e certas medidas cefalométricas em pacientes com más oclusões de Classe II de Angle não tratados ortodonticamente, MOONEN ${ }^{113}$, em 1991, selecionou uma amostra de 21 pacientes do gênero masculino e 13 do feminino, provenientes do arquivo Burlington Growth Centre, Universidade de Toronto. $\mathrm{T}_{1}$ e $\mathrm{T}_{2}$ corresponderam às idades cronológicas de 12 e 16 anos para o gênero masculino e 10 e 14 anos para o feminino, com um intervalo de quatro anos entre as tomadas, englobando o pico máximo de crescimento pubescente. Perante a inexistência de correlação entre 13 mensurações e a direção de crescimento mandibular (S-N.Gn), o autor descarta a previsibilidade do crescimento nos pacientes de Classe II.

URSI; McNAMARA JÚNIOR ${ }^{190}$, em 1997, verificaram as características dos pacientes apresentando más oclusões de Classe II, não submetidos a qualquer tipo de terapia, para se estabelecer parâmetros que possam ser utilizados como referência quando se avaliam terapias que visem à correção desta má oclusão. Neste sentido, selecionaram dois grupos, o primeiro com 29 jovens apresentando má oclusão de Classe II e outro com 30 jovens com oclusão "normal". De maneira geral, o grupo com Classe II apresentou, em relação ao grupo de oclusão "normal", a maxila posicionada de maneira semelhante no sentido ântero-posterior e a mandíbula mais retrognática, embora dimensionalmente equilibrada. Associaram este retrognatismo à altura ântero-inferior aumentada, com um vetor de crescimento craniofacial mais vertical. Em relação às alterações dento-alveolares, observaram os incisivos e molares superiores mais extruídos e os incisivos inferiores mais protruídos e extruídos nos jovens com Classe II em relação aos que apresentavam oclusão "normal".

Perante a prévia abordagem, observa-se uma diversidade de achados, podendo ser explicada, pelo menos em parte, pelas diferentes mensurações cefalométricas empregadas nas análises bem como a diferença entre os padrões populacionais. Contudo, a maioria dos autores concorda que a retrusão mandibular esquelética, quanto ao seu real tamanho ou quanto à sua posição relativa, é um importante componente na configuração da má oclusão de Classe II de Angle, divisão 1 , juntamente com uma protrusão dentária superior. $O$ desenvolvimento 
vertical excessivo, particularmente a altura facial anterior, também pode ser um componente significante ${ }^{100}$.

\subsection{Tratamento Ortopédico Funcional}

A ortopedia funcional dos maxilares vem, ao longo do tempo, firmando-se e consolidando-se como uma excelente forma de tratamento dos distúrbios estruturais e funcionais do Sistema Estomatognático. O aspecto principal da sua filosofia de tratamento das más oclusões, que a diferenciou da clássica movimentação ortodôntica, é o estímulo ou a restrição do crescimento ósseo pela utilização de forças naturais, originárias de trabalhos musculares ${ }^{108,171}$. Em outras palavras, com a utilização dos aparelhos ortopédicos funcionais, equilibram-se os músculos da mastigação, modificando concomitantemente e de forma gradativa a forma até alcançar o equilíbrio morfo-funcional, ou mesmo, ao se corrigir a discrepância esquelética, alterando o relacionamento espacial maxilomandibular, normaliza-se o desequilíbrio muscular bucofacial ${ }^{51,88,146}$.

Contudo, os trabalhos científicos mais recentes têm sugerido que o termo "funcional" não deva ser associado à atividade muscular, e sim às forças tissulares visco-elásticas ${ }^{197}$, pois se tem mostrado que o crescimento condilar, ou mesmo a remodelação óssea da articulação temporomandibular, como resultado do posicionamento anterior da mandíbula com estes aparelhos, não estão relacionados às contrações musculares ${ }^{177}$. Apesar da grande evolução científica e tecnológica, ainda há dicotomia de opiniões quanto às terminologias designadas aos tratamentos e quanto às reais respostas esqueléticas e dentárias com a utilização dos diversos aparelhos ortopédicos funcionais.

\subsubsection{Aparelho de Herbst}

O exímio professor alemão Emil Herbst ${ }^{76,132}$, no início do século passado, idealizou um aparelho fixo para o avanço mandibular e correção da Classe II, sem a necessidade da colaboração direta do paciente na sua utilização. A característica de 
avanço contínuo da mandíbula 24 horas por dia, impedindo-a de retroceder por um sistema telescópico bilateral com pistões e tubos, é o que o diferenciou da maioria dos outros aparelhos ortopédicos funcionais da época ${ }^{93}$. Esse mecanismo ficou conhecido universalmente como o Aparelho de Herbst, interpretado como um aparelho de ortopedia funcional fixo. Contudo, este aparelho entrou no esquecimento pela comunidade ortodôntica até a década de 70 , quando o pesquisador sueco Hans Pancherz ${ }^{205}$ o reintroduziu, despertando novamente grande interesse clínico ${ }^{172}$. A partir de então, ocorreu um grande avanço literário relatando pesquisas com o emprego desse aparelho por prestigiados nomes da Ortodontia, reportando as alterações dento-esqueléticas durante e posteriormente ao tratamento ${ }^{99,180}$.

PANCHERZ ${ }^{124}$, em 1979, empenhou-se em verificar os efeitos dentoesqueléticos da utilização do aparelho de Herbst, em jovens do gênero masculino com más oclusões de Classe II, divisão 1 de Angle. Os pacientes apresentavam-se em fase de crescimento, sem terem alcançado o pico máximo de crescimento puberal. Dez pacientes receberam o aparelho por seis meses, mantendo a mandíbula em uma posição protruída 24 horas/dia, com os incisivos superiores e inferiores numa posição de topo a topo e dez pacientes compuseram o grupo controle, sem algum tipo de tratamento pelo mesmo período de tempo. O aparelho de Herbst utilizado compôs-se por um mecanismo telescópico bilateral, onde o tubo se fixava à banda do primeiro molar superior permanente e o pistão à banda do primeiro pré-molar inferior. A ancoragem parcial superior, proposta neste estudo, compreendeu um fio por palatino nas duas hemiarcadas conectando o primeiro molar superior ao primeiro pré-molar superior, enquanto que a ancoragem inferior compreendeu um fio por lingual ligando os primeiros pré-molares inferiores. Em seis meses de tratamento, os resultados baseados na cefalometria e em análises de modelos mostraram uma normalização da condição oclusal. O comprimento mandibular (Co-Pog) aumentou em média 3,2mm nos pacientes tratados, enquanto que nos pacientes controles somente $1 \mathrm{~mm}$. Este resultado esclareceu a dúvida principal do pesquisador quanto ao possível estímulo no crescimento condilar com a utilização desse aparelho. Adicionalmente, verificou-se a redução do ângulo S.N.A (suavemente) e da convexidade facial, o aumento do ângulo S.N.B e da altura facial ântero-inferior, enquanto que o plano mandibular permaneceu inalterado. $\mathrm{O}$ autor concluiu que o sucesso do tratamento com o aparelho de Herbst deveu-se aos vários 
fatores já citados anteriormente e que esse estaria mais indicado nos casos que apresentassem mandíbula retrognática e incisivos inferiores lingualizados.

A análise eletromiográfica dos músculos temporal e masseter em decorrência do avanço mandibular, com o mesmo tipo de aparelho de Herbst utilizado anteriormente, foi a proposta de estudo de PANCHERZ; ANEHUSPANCHERZ ${ }^{133}$, em 1980. Trataram-se, por seis meses, dez pacientes do gênero masculino com más oclusões de Classe II, divisão 1 de Angle e idade inicial média de 12,08 anos. Colocaram-se eletrodos bilateralmente sobre os músculos masseter e temporal e as fases de estudo compreenderam períodos não só anteriores à terapia, como posteriores. Alcançaram-se relações normais de Classe I em todos os pacientes e observaram que mudanças morfológicas induzidas pelo tratamento, como a redução do ângulo A.N.B, principalmente pela alteração sagital da base apical inferior, podem afetar a função muscular e, possivelmente, explicar o aumento na atividade eletromiográfica dos músculos masseter e temporal durante a terapia.

Seguindo o seu método de análise, em 1981, PANCHERZ ${ }^{125}$ avaliou o mesmo grupo de pacientes, 12 meses após o tratamento com o aparelho de Herbst. Dentre os pacientes constituintes, sete apresentaram um relacionamento sagital normal dos arcos dentários e três apresentaram uma recidiva parcial, o que ele acreditou ser devido à intercuspidação instável após o tratamento. Não se observaram mudanças desfavoráveis no relacionamento sagital do osso mandibular após o tratamento, enquanto que o aumento no comprimento mandibular mostrou-se estável. O autor concluiu que, com o crescimento mandibular, o remodelamento dentofacial contribuiu para a correção da má oclusão de Classe II e que a intercuspidação dentária foi necessária para a manutenção da estabilidade dos casos tratados.

A dúvida quanto ao possível aumento do crescimento mandibular com o auxílio de aparelhos ortopédicos funcionais repercutiu na realização de duas pesquisas clínicas, com a utilização do aparelho de Herbst, na Faculdade de Odontologia da Universidade de Toronto. 
Um deles, MERCER ${ }^{110}$, em 1981, propôs avaliar os efeitos quantitativos e qualitativos do aparelho de Herbst no complexo dentofacial em adolescentes com más oclusões de Classe II, divisão 1 de Angle. O grupo experimental foi composto de sete pacientes, sendo quatro do gênero masculino e três do feminino, com a idade inicial média de 13,08 anos. Trataram-se os pacientes com o aparelho de Herbst tipo esplinte metálico, confeccionado a partir de uma liga de cromo-cobalto, com ancoragem parcial superior e inferior. Apresentavam retrognatismo mandibular, sobremordida profunda e foram tratados por seis meses com o aparelho. Já o grupo controle consistiu de 18 pacientes provenientes do arquivo Burlington Growth Centre, Universidade de Toronto, sendo 12 do gênero masculino e seis do feminino, durante os seis meses equivalentes ao grupo experimental. Quando instalados os aparelhos, os dentes anteriores apresentavam-se de topo. A avaliação cefalométrica obtida das radiografias laterais e oblíquas em $45^{\circ}$, antes e após o período estipulado, mostrou que o comprimento mandibular aumentou em média 3,03 $\mathrm{mm}$ no grupo experimental, enquanto 1,58mm no grupo controle. Apesar da significância estatística desta grandeza linear (Co-Pog), o autor enfatiza que o erro da medida mostrou-se considerável enquanto que os aumentos individuais no comprimento mandibular apresentaram-se bem variáveis. Resultados extras mostraram que $\overline{1}-\mathrm{NB}$ aumentou em média 2,96mm no grupo experimental e $0,06 \mathrm{~mm}$ no grupo controle; a AFAI aumentou em média $1,28 \mathrm{~mm}$ no grupo experimental, enquanto que $0,65 \mathrm{~mm}$ no controle, porém não estatisticamente significante; o comprimento da unidade maxilar diminuiu em média $0,23 \mathrm{~mm}$ no grupo experimental, enquanto que, no controle, 0,85mm de aumento; o FMA diminuiu $0,1^{\circ}$ no grupo experimental, enquanto que, no controle, aumentou $0,05^{\circ}$, porém não estatisticamente significante; e, finalizando, a medida S.N.Pog aumentou $1,83^{\circ}$ no grupo experimental e aumentou $0.06^{\circ}$ no controle.

Em 1982, HUTCHISON ${ }^{83}$ examinou a estabilidade das mudanças esqueléticas e dentárias produzidas pelo posicionamento contínuo anterior da mandíbula com o aparelho de Herbst, na mesma amostra de adolescentes em crescimento utilizada por Mercer $^{110}$. O grupo controle, por sua vez, compôs-se de 14 pacientes não tratados ortodonticamente, sendo seis do gênero feminino e oito do masculino, e com a idade inicial média de 12,08 anos, provenientes do arquivo Burlington Growth Center, Universidade de Toronto. Obtiveram-se radiografias em 
norma lateral e oblíquas em $45^{\circ}$ ao início, ao final (seis meses de tratamento) e póstratamento (mínimo de 6,5 meses a 10 meses). Mediante os resultados obtidos, os pacientes tratados exibiram aumentos significantes nas mensurações Co-Gn (apenas nas telerradiografias), SN.PP, S.N.B, $\overline{1} . N B, \overline{1}-\mathrm{NB}$, posição ântero-posterior dos primeiros molares inferiores e diminuições também significantes nas mensurações Co-ENA, SN.GoMe, N.A.Pog, A.N.B, sobremordida, sobressaliência, 1-NA e posição dos primeiros molares superiores no sentido vertical e sagital. Entretanto, não se observaram diferenças significantes entre os grupos quanto às mensurações Co-Gn (nas radiografias oblíquas em $45^{\circ}$ ), S.N.A, 1.NA e posição no sentido vertical dos primeiros molares inferiores. $O$ autor salienta a não-diferença quanto ao comprimento mandibular provenientes de radiografias oblíquas em $45^{\circ}$, e que o crescimento no pogônio foi expresso no sentido horizontal como resultado do controle da dimensão vertical.

Em uma diferente abordagem clínica, SARNAS; PANCHERZ; RUNE; SELVIK ${ }^{174}$, em 1982, estudaram o efeito do aparelho de Herbst, tipo bandado com ancoragem total inferior, em um paciente do gênero masculino com microssomia hemifacial. Previamente ao tratamento, aos 14 anos de idade, os maxilares apresentavam-se deslocados para posterior e para o lado afetado enquanto que o crescimento favorecia o aumento no grau de retrognatismo e assimetria facial. Em observações sucessivas, por um período de dois anos, o tratamento com o aparelho de Herbst reduziu a retrognatia e a assimetria por redirecionar o crescimento facial e deslocar os maxilares para a anterior e para o lado não afetado. Os autores sugeriram que a correção da má oclusão foi em decorrência da remodelação dentoalveolar e do deslocamento dos maxilares.

No mesmo ano, PANCHERZ ${ }^{126}$ propôs avaliar quantitativamente as mudanças esqueléticas e dentárias, em pacientes que se submeteram ao tratamento ortodôntico com o emprego do aparelho de Herbst, necessárias à correção da má oclusão de Classe II, divisão 1 de Angle. O grupo experimental consistiu de 22 pacientes, sendo 19 do gênero masculino e três do gênero feminino, com a idade inicial média de 12,08 anos, tratados durante um período de seis meses. Selecionaram-se 20 pacientes como grupo controle, sendo 17 do gênero masculino e 3 do feminino com a idade inicial média de 11,16 anos, apresentando a mesma má 
oclusão e morfologia esquelética inicial do grupo experimental. Preconizou-se, neste estudo, o mesmo aparelho utilizado pelo autor em 1979, porém em quatro casos, estendeu-se a ancoragem inferior até a região dos primeiros molares inferiores. Os incisivos apresentavam-se numa relação de topo a topo com o aparelho, posicionando os arcos dentários numa relação molar de Classe I ou mesmo sobrecorrigidos. Constituindo a análise cefalométrica, quatro mensurações dentárias são destacadas: posição ântero-posterior dos incisivos centrais superior e inferior (distância linear entre os pontos localizados nas incisais dos incisivos e a perpendicular ao plano oclusal, passando pelo ponto S) e a posição ântero-posterior dos primeiros molares superior e inferior (distância linear entre os pontos localizados nas mesiais dos molares e a perpendicular ao plano oclusal, passando pelo ponto $S$ ). Avaliando-se as grandezas cefalométricas angulares e lineares estabelecidas, por meio das telerradiografias iniciais e finais ao período de tratamento e ao de observação, pode-se concluir que a melhora alcançada no relacionamento molar e incisal dos pacientes tratados foi um resultado aproximado de mudanças esqueléticas e dentárias. A correção da sobressaliência (média de 5,2mm) resultou do aumento no comprimento mandibular e da vestibularização dos incisivos inferiores e a melhora na relação molar $(6,7 \mathrm{~mm})$ em decorrência do aumento no comprimento mandibular, distalização dos molares superiores e mesialização dos molares inferiores. O deslocamento condilar para a anterior, o redirecionamento do crescimento maxilar e a lingualização dos incisivos superiores tiveram somente uma pequena contribuição na melhora do relacionamento molar e incisal. Salientou-se ainda a existência de uma relação direta entre a quantidade de avanço mandibular no início do tratamento e os efeitos terapêuticos na oclusão e no crescimento mandibular.

Em 1985, PANCHERZ; HÄGG ${ }^{137}$, expuseram os seus pontos de vista quanto à eficácia do aparelho de Herbst, levando em consideração a época de instalação do aparelho. Setenta pacientes, sendo 52 do gênero masculino e 18 do feminino, de 10 a 16 anos com más oclusões de Classe II de Angle, compuseram o grupo experimental tratados por um período médio de 7,1 meses. Já o grupo controle compôs-se de 23 pacientes, todos do gênero masculino, de nove a 14 anos, analisados por um período médio de 6,2 meses. Os resultados mostraram que o efeito ortopédico era mais significativo, sobrepujando as compensações dentárias, 
quando o aparelho era instalado na época do pico de crescimento estatural e viceversa - as compensações dentárias predominaram quando o aparelho era instalado após o pico de crescimento estatural.

PANCHERZ ${ }^{127}$, em 1985, selecionou 22 pacientes, que apresentavam más oclusões de Classe II na dentadura mista, tratados com o aparelho de Herbst, com o intuito de resumir os efeitos biológicos desta terapêutica e discutir a sua aplicação clínica. Utilizou-se o aparelho de Herbst tipo bandado, com a ancoragem parcial em ambos os maxilares na maioria dos casos. Após um período médio de tratamento de seis meses, ao se comparar com um grupo controle composto por 20 pacientes, verificou-se a correção da relação molar, bem como da sobressaliência nos pacientes tratados. O autor alega essas correções às mudanças dentárias e às mudanças esqueléticas como: vestibularização dos incisivos inferiores e manutenção dos superiores; distalização dos molares superiores e mesialização dos inferiores; restrição do crescimento maxilar e estímulo do crescimento mandibular; aumento do comprimento mandibular; intrusão dos incisivos inferiores e dos primeiros molares superiores e extrusão dos molares inferiores. Como resultado das mudanças dentárias, a altura facial ântero-inferior foi aumentada. Contudo, o autor relatou que o aumento dessa altura foi temporário, pois após reexaminar os pacientes 12 meses pós-tratamento, a altura era coincidente com a do grupo controle. Por fim, resumiram-se algumas características clínicas e radiográficas de um bom perfil de paciente para a indicação do aparelho de Herbst: mandíbula retrognata, padrão de crescimento facial no sentido horizontal, altura facial ântero-inferior reduzida ou normal, dentes alinhados e boa relação entre os arcos dentários, ao encaixá-los no sentido sagital.

Em 1986, PANCHERZ; HANSEN ${ }^{138}$ avaliaram, quantitativamente, as alterações dento-esqueléticas estimuladas pelo aparelho de Herbst em 40 pacientes com más oclusões iniciais de Classe II, divisão 1 de Angle. Prescreveram a ancoragem parcial em 16 pacientes e a total em 24 pacientes e os resultados cefalométricos, obtidos de telerradiografias, foram analisados no início, no final, seis meses e doze meses após o tratamento. No final do período experimental, quando da remoção da aparatologia, sete pacientes apresentaram uma relação molar de Classe I e 33 pacientes apresentaram uma sobrecorreção desta relação. A melhora 
na relação sagital, verificada pela relação molar e incisivo, resultou de mudanças esqueléticas e dentárias. A relação interdentária, verificada pela sobressaliência, foi reduzida em média $6,9 \mathrm{~mm}$, com $2,2 \mathrm{~mm}$ de crescimento mandibular a mais que o maxilar, 2,3mm de retrusão dos incisivos superiores e $2,4 \mathrm{~mm}$ de protrusão dos incisivos inferiores. A relação molar, por conseguinte, foi melhorada em média 6,3mm, com influência de 2,0 mm de distalização dos molares superiores, 2,1 $\mathrm{mm}$ de mesialização dos molares inferiores, além da diferença de crescimento constatada entre os ossos basais. Os autores concluíram que as mudanças dentárias na maxila, bem como na mandíbula, foram basicamente resultados de perda de ancoragem durante a utilização do aparelho ortopédico fixo, e que o tipo de ancoragem empregado não influenciou na quantificação dessas perdas de ancoragem, mostrando-se similares os seus efeitos. Eles acreditaram ser o período de intervenção mais importante na determinação da perda de ancoragem do que o próprio tipo de aparelho, pois os pacientes desta pesquisa que receberam a ancoragem total eram pacientes mais velhos e foram esses que apresentaram maiores movimentações dentárias.

A eficiência de cinco sistemas de ancoragem mandibular no tratamento de más oclusões de Classe II, divisão 1 com o aparelho de Herbst foi motivo de investigação por PANCHERZ; HANSEN ${ }^{139}$, em 1988. Selecionaram-se 65 pacientes, sendo 48 do gênero masculino e 17 do feminino, com idades variando de 10 a 16 anos, tratados com o aparelho funcional fixo por um período médio de sete meses. Avaliações cefalométricas e oclusais foram efetuadas no início e final do tratamento, bem como, 6 e 12 meses pós-tratamento. De acordo com o tipo de ancoragem utilizada no arco inferior, dividiram-se os pacientes em cinco grupos: ancoragem de pré a pré-molar, com um fio por lingual tocando na superfície lingual dos incisivos inferiores (avanço médio inicial de 7,5mm); ancoragem de molar a molar, com um fio por lingual tocando na superfície lingual de todos os dentes (avanço médio inicial de 8,4mm); ancoragem de molar a molar, porém com acrílico por lingual na região dos incisivos e caninos (avanço médio de 7,8mm); ancoragem de molar a molar, porém com braquetes por vestibular de pré a pré-molar (avanço médio de 9,3mm) e, por fim, ancoragem com elástico de Classe III adicionado ao último tipo de ancoragem com braquetes (avanço médio de 8,4mm). Nos 65 pacientes investigados, em sete meses de terapia, resultou-se numa protrusão e vestibularização dos incisivos inferiores $(X=$ 
2,5mm e $9,4^{\circ}$ respectivamente), e também numa mesialização dos molares inferiores $(X=1,9 \mathrm{~mm})$. Constatou-se que, quanto maior o avanço mandibular inicial realizado com o aparelho, maior a movimentação dentária durante o tratamento. Os autores aclamaram, na discussão do trabalho, que a perda de ancoragem inferior é um problema difícil de se controlar no tratamento com o aparelho de Herbst, pois nenhum dos cinco tipos de ancoragem prescritos pôde resistir à tensão colocada na região anterior do arco dentário pelo mecanismo de Classe II. Talvez a severidade da discrepância no sentido ântero-posterior seja também decisiva nas alterações dentárias. Por outro lado, a perda de ancoragem nos molares inferiores mostrou-se menor com a ancoragem de pré a pré-molar, não surpreendendo os resultados, já que esses elementos dentários não se encontravam conectados ao aparelho.

No mesmo ano, HÄGG; PANCHERZ ${ }^{62}$ estudaram a influência da idade cronológica, do período de crescimento em altura e da maturidade esquelética dos pacientes nas alterações dentárias e esqueléticas mandibulares no sentido sagital que ocorreram durante o tratamento com o aparelho de Herbst. Para tanto, utilizaram-se 72 pacientes do gênero masculino, com más oclusões de Classe II, divisão 1 , submetidos à terapia fixa, com o avanço mandibular realizado de forma única, por um período médio de tratamento de 7,2 meses. O nível de maturação dos pacientes durante o tratamento ortodôntico variaram entre três anos antes e três anos após o pico de velocidade em altura. Houve uma associação estatisticamente significante entre o crescimento condilar no sentido sagital e o período de crescimento em altura em que os pacientes se encontravam. $O$ crescimento condilar nos pacientes tratados durante o pico foi duas vezes maior que o observado em pacientes tratados três anos antes ou três anos após. A média da idade cronológica durante esse pico de crescimento foi de 13,9 anos. Com relação à maturidade esquelética, houve também uma associação significante entre o crescimento condilar no sentido sagital e o desenvolvimento esquelético. Os pacientes tratados durante o fechamento inicial da falange média do terceiro dedo obtiveram a maior quantidade de crescimento condilar. Os resultados deste estudo indicaram que a idade cronológica não é um indicador acurado da capacidade do crescimento condilar, e que a avaliação da posição do paciente na curva de crescimento em altura foi um método indireto útil de avaliação da capacidade de crescimento mandibular. Concluiu-se que, pelo menos em homens, há uma associação próxima entre o 
crescimento pubescente máximo em altura (pico) e o crescimento mandibular máximo e que a quantidade de mudança na posição dos incisivos inferiores durante o tratamento instituído não parece estar relacionado às variáveis investigadas, contudo com suave tendência à perda de ancoragem três anos pós-pico de crescimento.

PANCHERZ; MALMGREN; HÄGG; ÖMBLUS; HANSEN ${ }^{140}$, em 1989, avaliaram quantitativamente, em telerradiografias, as alterações dentárias e esqueléticas, que contribuíram para a correção da Classe II, proporcionadas pelo aparelho de Herbst e pelo aparelho de Bass. Selecionaram-se 18 pares de pacientes do gênero masculino, sendo cada par contendo um paciente de cada modalidade de tratamento. O período médio de tratamento em ambas terapias foi de seis meses, com a idade inicial variando entre 10 a 13 anos para os pacientes tratados com o aparelho de Herbst e entre 10 a 15 anos para os pacientes tratados com o aparelho de Bass. O aparelho de Herbst empregado foi o do tipo bandado com ancoragem total superior e inferior, com avanço mandibular realizado de forma única, obtendo uma relação de topo a topo entre os incisivos. Utilizou-se o aparelho de Bass, representado por um aparelho funcional removível associado ao aparelho Extrabucal de tração occipital, com o avanço mandibular reativado por $2 \mathrm{~mm}$ a cada seis semanas. Após o período experimental, nos pacientes tratados com o aparelho ortopédico fixo, a sobressaliência apresentava-se menor, a relação molar melhorada, o plano oclusal inclinado, o ângulo do plano mandibular aumentado, os incisivos superiores mais verticalizados e os incisivos inferiores mais vestibularizados que nos pacientes tratados com a mecânica removível. Concluíram que o tratamento com o aparelho de Herbst é mais rápido e mais consistente, com grande vantagem sobre a utilização do aparelho de Bass por ser fixo e não requerer a cooperação do paciente.

No mesmo ano, VALANT; SINCLAIR ${ }^{194}$ estudaram os efeitos dentoesqueléticos produzidos pelo aparelho de Herbst, tipo esplinte de acrílico removível inferior, utilizado por um tempo médio de tratamento de 10 meses. O grupo experimental incluiu 32 pacientes com más oclusões de Classe II, divisão 1, com 14 componentes do gênero masculino e 18 do feminino, com a idade inicial média de 10,16 anos e o grupo controle foi pareado ao experimental, quanto à má oclusão, idade e gênero. Os dados cefalométricos evidenciaram que a correção da relação 
molar foi alcançada, em média, pela distalização dos molares superiores em 1,5mm, pela restrição do crescimento maxilar em $0,7 \mathrm{~mm}$, pela mesialização dos molares inferiores em 1,6mm e pelo crescimento mandibular em 3,3mm. Com esse tipo de aparelho, os molares superiores apresentaram uma inclinação da coroa para distal em média $6,4^{\circ}$ e os incisivos inferiores mostraram pouca vestibularização. Atribuíram ao aparelho de Herbst a vantagem em se distalizar os molares superiores, o que não era visto, até então, pelos os outros aparelhos funcionais. Os autores assemelharam a ação mecânica do aparelho de Herbst sobre a maxila, em relação à distalização dos molares superiores e restrição do crescimento maxilar, com a mecânica promovida pelo aparelho Extrabucal de tração occipital.

Também no ano de 1989, BAKKE; PAULSEN ${ }^{6}$ propuseram identificar os efeitos da aplicação do aparelho de Herbst em um paciente do gênero masculino com 16,9 anos, que apresentava severa má oclusão de Classe II. Instalou-se inicialmente, por seis meses, o aparelho de Herbst com ancoragem total, com o avanço do mecanismo telescópico por 15mm, seguido por uma mecanoterapia englobando a aparelhagem fixa, o aparelho Extrabucal de tração occipital e novamente o aparelho de Herbst. Mediante os resultados, concluiu-se que a indicação do aparelho de Herbst na correção de extensas sobressaliências pode ser benéfica em pacientes com idades mais avançadas, sendo uma alternativa à cirurgia ortognática, com alterações dento-alveolares e esqueléticas bem sucedidas.

Indagados quanto à adaptação do crescimento craniofacial póstratamento, em pacientes que foram submetidos à correção ortopédica com o aparelho de Herbst, PANCHERZ; FACKEL ${ }^{136}$, em 1990, propuseram estudar os efeitos a curto e a longo prazo desta mecanoterapia. Selecionaram 17 pacientes do gênero masculino com más oclusões de Classe II, divisão 1, anteriores ao surto de crescimento pubescente, que foram investigados no início da terapia (idade inicial média de 12,9 anos), no final (idade inicial média de 13,5 anos) e pós-tratamento (idade inicial média de 16,1 anos). Dentro do protocolo de tratamento, estipulou-se o avanço mandibular numa relação de topo a topo em todos os pacientes, com a obtenção da relação molar de Classe I num período médio de tratamento de sete meses. Observaram, a curto prazo, uma restrição do crescimento maxilar e um estímulo do crescimento mandibular, melhorando a discrepância intermaxilar no 
sentido sagital, contribuindo definitivamente para a melhora do perfil esquelético. Os autores concluíram que, quanto às condições diagnosticadas pós-tratamento, motivo principal de suas pesquisas, o padrão morfogenético herdado pelo paciente é extremamente importante no planejamento terapêutico, pois este acompanha e influencia por toda a vida os entrelaçamentos esqueléticos.

No mesmo ano, McNAMARA JÚNIOR; HOWE; DISCHINGER ${ }^{106}$ compararam os efeitos produzidos pela utilização do aparelho de Fränkel e pelo aparelho de Herbst, tipo esplinte de acrílico, em pacientes que apresentavam más oclusões de Classe II, divisão 1. Selecionaram-se 41 pacientes (22 do gênero feminino e 19 do masculino) tratados com o aparelho de Fränkel por um período médio de 21 meses, com a idade inicial média de 11,5 anos, e 45 pacientes (18 do gênero feminino e 27 do masculino) tratados com o aparelho de Herbst por um período médio de 12 meses, com a idade inicial média de 12 anos. Um grupo controle também foi selecionado, com 21 pacientes (13 do gênero feminino e 8 do masculino) e a idade inicial média de 11,08 anos. Pela análise cefalométrica, com os dados anualizados, pôde-se observar que ambas as terapias produziram efeitos esqueléticos e dento-alveolares no complexo craniofacial, porém em áreas específicas dependendo do aparelho utilizado. Em geral, nem o aparelho de Fränkel, nem o de Herbst, apresentaram um efeito estatisticamente significante sobre 0 crescimento maxilar. Apenas o ponto A foi suavemente movimentado pelo uso do aparelho de Herbst, podendo ser este resultado interpretado pela lingualização dos incisivos superiores. Os molares superiores foram restringidos verticalmente e distalizados no grupo tratado com o aparelho de Herbst em comparação aos demais grupos. Os molares inferiores foram mesializados com o aparelho de Herbst e erupcionados com ambas as terapias e os incisivos inferiores vestibularizados apenas com a mecânica do Herbst. Os dois aparelhos aumentaram o comprimento mandibular e a altura facial ântero-inferior, bem como a altura facial posterior, não influenciando conseqüentemente o ângulo do plano mandibular. Os autores concluíram que as maiores alterações dento-alveolares são obtidas em pacientes que utilizam o aparelho ortopédico dento-suportado que os que utilizam o mucosuportado. 
Em 1991, HANSEN; PANCHERZ; HÄGG67 propuseram avaliar as alterações no complexo dentofacial, a curto (média de sete meses) e principalmente a longo prazo (média de 6,6 anos), com especial referência ao período de crescimento em que os pacientes foram tratados com o aparelho ortopédico funcional de Herbst. Quarenta pacientes, do gênero masculino com más oclusões de Classe II, divisão1, compuseram a amostra, divididos em três grupos de acordo com o período de crescimento em que foram tratados (antes, durante e após o pico de crescimento pubescente). A avaliação clínica e a cefalométrica permitiram diagnosticar a melhora no relacionamento sagital entre os arcos dentários a curto e a longo prazo. As alterações dentárias foram diferenciadas com relação à época de tratamento: os incisivos e molares superiores foram movimentados mais para a posterior nos pacientes que foram tratados durante e após o pico de crescimento; os incisivos inferiores foram movimentados mais para a anterior nos pacientes que foram tratados antes do pico de crescimento; e os molares inferiores foram movimentados mais anteriormente nos pacientes que foram tratados antes e durante o pico de crescimento. Resumidamente, os achados deste estudo revelaram que o período de crescimento, em que os pacientes foram submetidos à terapia ortopédica, não influenciou os resultados a longo prazo. Uma explicação desta similaridade pode ser atribuída ao fato de que o aparelho de Herbst aumenta o crescimento condilar no sentido sagital na mesma quantidade, independente do período de maturação somática em que os pacientes se encontram. Deram importância também à estabilidade oclusal alcançada, mais do que propriamente o padrão de crescimento pós-tratamento, na finalização do tratamento para a obtenção da estabilidade a longo prazo. Concluíram que o período ideal para o tratamento seria na dentadura permanente, ou logo após o pico de crescimento em altura, promovendo estabilidade oclusal e redução no tempo de uso da contenção.

No ano seguinte, HANSEN; PANCHERZ ${ }^{66}$ propuseram avaliar cefalometricamente as alterações no complexo dentofacial, a curto (média de sete meses) e a longo prazo (média de 6,7 anos), em pacientes tratados com o aparelho ortopédico funcional de Herbst, comparados com pacientes que apresentavam o crescimento e desenvolvimento normais. 32 pacientes, sendo 16 do gênero feminino e 16 do masculino, com más oclusões de Classe II, divisão1 e idade inicial média de 12,53 anos, compuseram o grupo experimental e 32 pacientes, pareados quanto à 
idade e gênero, compuseram o grupo controle, que apresentavam excelentes oclusões. Verificou-se que, a curto prazo, o relacionamento sagital entre os arcos dentários melhorou com a mecânica, enquanto que no grupo controle permaneceu inalterado. Essa melhora no grupo experimental foi em decorrência do resultado das alterações dentárias e esqueléticas favoráveis. A longo prazo, o relacionamento basal maxilomandibular é melhorado, mas não normalizado com o tratamento. As alterações dentárias, como parte do resultado do tratamento, podem compensar o relacionamento desfavorável entre as bases neste período.

SCHIAVONI; GRENGA; MACRII ${ }^{176}$, em 1992, estudaram os resultados decorrentes do tratamento da má oclusão de Classe II, utilizando dois tipos de aparelhos de Herbst. A amostra compôs-se de 19 jovens (13 meninos e 6 meninas), sendo dividida em dois grupos de pacientes apresentando padrões de crescimento craniofacial distintos: o grupo mesofacial (11 casos), tratado com o aparelho de Herbst do tipo bandado (seguindo o mesmo desenho preconizado por Pancherz ${ }^{124}$, porém com ancoragem total superior) e o dolicofacial (8 casos) com o aparelho de Herbst do tipo colado (esplintes de acrílicos superior e inferior - mesmo preconizado por $\mathrm{McNamara}^{102}$ ) associado à ancoragem extrabucal de tração alta. Preconizou-se em todos os casos o tempo de tratamento de nove meses, e a idade inicial média era de 11,16 anos. Comparando-se as telerradiografias iniciais e finais do grupo experimental com as teles pareadas cronologicamente do grupo controle, denotaram que todos os casos obtiveram a correção da relação molar de Classe II no tempo de tratamento pré-estabelecido. O aparelho de Herbst do tipo bandado não modificou significantemente o padrão de crescimento nos pacientes mesofaciais, enquanto que o tipo colado associado ao aparelho Extrabucal de tração alta permitiu um maior controle da dimensão vertical no grupo com padrão de crescimento craniofacial no sentido vertical, promovendo uma rotação anti-horária da mandíbula, conforme verificado pelas medidas cefalométricas FMA e SN.GoGn. A melhor estratégia para um exímio tratamento com o aparelho de Herbst é ter conhecimento das diferentes mudanças dentofaciais provocadas pelos diferentes tipos deste aparelho.

No mesmo ano, HÄGG ${ }^{59}$ descreveu minuciosamente um caso tratado com o aparelho de Herbst com ancoragem total, seguido pelo o aparelho Ativador, de uma menina de 9,6 anos de idade. Observou-se cefalometricamente que em dez meses 
de terapia com o aparelho ortopédico fixo, a relação dentária de Classe II converteuse em Classe I, com uma sobrecorreção da sobressaliência. A melhora da relação maxilomandibular (redução do ângulo A.N.B de $11^{\circ}$ para $6^{\circ}$ ) deveu-se ao crescimento anterior aumentado da mandíbula e inibição do crescimento anterior da maxila. Constatou-se, adicionalmente, uma vestibularização acentuada dos incisivos inferiores. O autor concluiu que o incremento do crescimento mandibular alcançado com o aparelho de Herbst foi em decorrência do período de tratamento estipulado, ou seja, durante a velocidade máxima de crescimento mandibular, sendo este identificado pela curva de velocidade em altura que se expressam simultaneamente.

Em virtude da pouca atenção despendida na literatura aos efeitos do tratamento com o aparelho de Herbst sobre a maxila, em 1993, PANCHERZ; ANEHUS-PANCHERZ ${ }^{134}$ investigaram cefalometricamente os efeitos a curto e a longo prazo desta terapia, no complexo maxilar, em jovens que apresentavam inicialmente a má oclusão de Classe II, divisão 1 de Angle. A amostra compôs-se de 34 pacientes do gênero masculino e 11 do feminino, vivenciando o período máximo de crescimento, avaliados longitudinalmente por um tempo médio pós-tratamento de 6,4 anos (de cinco a 10 anos). O desenho do aparelho de Herbst utilizado neste estudo é o mesmo que o autor preconiza em seus estudos antecedentes, com a ancoragem parcial em 19 pacientes (até a região dos pré-molares) e a total em 26 (todos os dentes). Avaliaram-se as telerradiografias no início, no final do tratamento (sete meses) e pós-tratamento (após seis meses e 6,4 anos). Avaliou-se também um grupo controle, equiparado cronologicamente e com as mesmas características esqueléticas, nos períodos de observação inicial e final de tratamento e, para comparar os efeitos pós-tratamento da terapia, consideraram-se as características de um grupo de oclusão ideal. Mediante a obtenção dos resultados, no final do período terapêutico, observaram que, em média, os primeiros molares superiores movimentaram em direção distal $2,1 \mathrm{~mm}$ e foram intruídos $0,7 \mathrm{~mm}$; o plano oclusal superior inclinou em sentido horário $2,0^{\circ}$ e o palatino, $0,2^{\circ}$ e a posição no sentido ântero-posterior da maxila mostrou-se inalterada pela mecânica aplicada. Em contrapartida, no grupo controle, os primeiros molares superiores, em média, movimentaram mesialmente $0,3 \mathrm{~mm}$ e extruíram $0,4 \mathrm{~mm}$; o plano oclusal inclinou em sentido anti-horário $0,4^{\circ}$ e o plano palatino, bem como a maxila, não mostraram diferenças estatisticamente significantes. Durante os seis primeiros meses após a 
retirada do aparelho, verificaram que as mudanças oriundas do tratamento reverteram-se consideravelmente. Durante os seguintes 5,9 anos pós-tratamento, as mudanças esqueléticas e dentárias observadas na base apical superior foram resultadas principalmente do desenvolvimento normal do crescimento: os molares superiores mesializaram e extruíram; o plano oclusal inclinou mais em sentido antihorário; a maxila cresceu em sentido anterior e o plano palatino inclinou para baixo. Entretanto, ao comparar os pacientes de Herbst com os de oclusão ideal pertencentes ao grupo controle no final do período de observação (média de 6,4 anos após a terapia), notou-se que a quantidade de crescimento maxilar sagital foi menor nos casos de Classe II tratados. Não se constatou nenhuma diferença na quantidade de movimento no sentido vertical e sagital dos molares superiores ao se compararem os dois sistemas de ancoragem. No desfecho do trabalho, os autores concluem que o aparelho de Herbst exibe um efeito similar ao do Extrabucal de tração occipital no complexo maxilar, especialmente quanto à distalização dos primeiros molares superiores, porém passível de recidiva.

Comparando as alterações cefalométricas em pacientes com más oclusões de Classe II, divisão 1, tratados com os aparelhos Extrabucal cervical, Fränkel e Herbst, URSI ${ }^{189,191}$, em 1993, propôs verificar os efeitos desses aparelhos sobre o complexo craniofacial. A amostra foi constituída de telerradiografias em norma lateral de 30 pacientes tratados com o aparelho extrabucal, 35 com o regulador de função de Fränkel e 29 com o aparelho de Herbst. Para tanto, selecionou um grupo controle composto por 29 jovens não tratados e com más oclusões iniciais similares. Os resultados permitiram observar um maior crescimento mandibular nos grupos tratados com os aparelhos ortopédicos funcionais, simultaneamente a um aumento no grau de protrusão mandibular, comparando-se com os grupos tratados com o aparelho extrabucal cervical e o controle. O padrão de crescimento craniofacial não foi influenciado em nenhum grupo tratado. Notou-se, também, um incremento das alturas faciais anterior e posterior significantes nos 3 grupos experimentais, concentrado principalmente nos terços inferiores dos pacientes tratados com o regulador de função de Fränkel e com o aparelho de Herbst. Verificando os componentes dento-alveolares, observou uma significante retrusão dos incisivos superiores nos jovens tratados com os aparelhos extrabucal cervical e Fränkel, enquanto as posições horizontal e vertical dos molares superiores 
demonstraram uma maior influência com o aparelho de Herbst. Os incisivos inferiores apresentaram uma discreta tendência à linguoversão com o aparelho extrabucal; no grupo tratado com o Fränkel, essa tendência foi de intensidade similar, porém na direção oposta; e um aumento substancial na protrusão desses dentes, bem como uma expressiva mesialização dos molares inferiores foi constatada com o aparelho de Herbst.

Em 1994, PANCHERZ; ANEHUS-PANCHERZ ${ }^{135}$ avaliaram os efeitos a curto e a longo prazo da utilização do aparelho de Herbst no perfil facial duro e mole de 69 pacientes, de ambos os gêneros, com más oclusões de Classe II, divisão1, tratados por um período de seis a oito meses. Para a comparação dos efeitos durante o tratamento, utilizou-se um grupo controle de 24 componentes, com mesmas morfologias dentofaciais que a apresentada pelo grupo experimental ao início da terapia. Os resultados cefalométricos evidenciaram que, ao final da instituição do aparelho, o ângulo do perfil duro (N.A.Pog), o ângulo do perfil mole, sem incluir o nariz (N'.Sn.Pog') e o ângulo do perfil mole, incluindo o nariz (N.Prn.Pog) aumentaram com a mecânica. O lábio superior, em relação à linha $E$, tornou-se retrusivo em todos os pacientes, enquanto que o lábio inferior tornou-se retrusivo em $60 \%$ dos casos e protrusivo em $40 \%$ dos casos, sem haver diferença significante desta última variável quando comparada com o grupo controle. Houve uma correlação positiva entre as mudanças ocorridas no perfil duro com as mudanças ocorridas no perfil mole (incluindo e excluindo o nariz); uma correlação positiva entre as alterações na convexidade do perfil mole, incluindo e excluindo o nariz; e também uma correlação positiva das alterações do lábio superior com o lábio inferior a curto prazo. Concluiu-se que o aparelho de Herbst retifica os perfis duro e mole de modo consistente, diminuindo a convexidade facial e contribuindo com a estética. Constatou-se que, com o movimento anterior do queixo, o lábio superior foi, conseqüentemente, posicionado mais retrusivamente em relação à linha $E$, enquanto que o lábio inferior seguiu ocasionalmente o movimento mandibular.

SIDHU; KHARBANDA; SIDHU ${ }^{179}$, em 1995, foram estimulados a investigar as alterações dento-esqueléticas decorrentes da utilização do aparelho de Herbst tipo esplinte de acrílico em oito garotas com más oclusões de Classe II, divisão 1 , entre 10 a 12 anos de idade. Para a comparação dos resultados alcançados com a 
terapia de escolha, utilizou-se um grupo controle, pareado ao grupo experimental quanto à idade, gênero, tipo e severidade da má oclusão. Análises cefalométricas foram requisitadas no início do tratamento e após oito meses. Os valores obtidos mostraram que o ângulo S.N.B aumentou em média $2,9^{\circ}$, o ângulo A.N.B diminuiu em média $2,1^{\circ}$ e o S.N.A aumentou em média $0,8^{\circ}$, embora este último não seja estatisticamente significante. A altura facial posterior total aumentou em aproximadamente a mesma quantia da altura facial anterior e o ângulo do plano mandibular reduziu em $0,4^{\circ}$, representando uma rotação anterior suave da mandíbula. A redução da sobressaliência foi expressiva, em média 5,6mm, com uma lingualização dos incisivos superiores e vestibularização dos inferiores. Os dentes ântero-inferiores, além de terem vestibularizados em média 5,30 também intruíram por volta de $1,4 \mathrm{~mm}$ de modo significante. Os autores explicam parte deste achado (intrusão) pela vestibularização dos mesmos devido ao vetor de força aplicada mesialmente sobre esses dentes. Em relação aos primeiros molares, os superiores inclinaram para distal em média $5,6^{\circ}$ e os inferiores protruíram e mesializaram em média 3,8mm e 3,6 respectivamente, contribuindo para a correção da relação molar, além da contribuição do posicionamento anterior mandibular e aumento efetivo no seu comprimento.

No mesmo ano, PAULSEN; KARLE; BAKKE; HERSKIND ${ }^{144}$ reportaram o tratamento com o aparelho de Herbst, por sete meses, de um paciente do gênero masculino com severa má oclusão de Classe II, divisão 1, com 14 anos de idade, em fase pós-pico de crescimento pubescente. Avançou-se a mandíbula por $14 \mathrm{~mm}$, com reativação de $3 \mathrm{~mm}$ no terceiro mês. $A$ análise cefalométrica revelou um aumento no comprimento mandibular de $6 \mathrm{~mm}$, um aumento na altura no ramo mandibular de $4 \mathrm{~mm}$ e uma rotação em sentido anterior da mandíbula de $3^{\circ}$. A lingualização dos incisivos superiores e a vestibularização dos inferiores contribuíram para a correção da sobressaliência e da sobremordida, e a mesialização de $5 \mathrm{~mm}$ dos molares inferiores contribuiu para a correção da relação molar. Três meses após a inserção do aparelho, a ortopantomografia da articulação temporomandibular revelou nova formação óssea, diagnosticada pelo contorno duplo da fossa e do côndilo mandibular, como resultado da remodelação óssea adaptativa. 
Em 1996, RUF; PANCHERZ ${ }^{165}$ avaliaram cefalometricamente a reação individual e os efeitos a curto (sete meses de tratamento) e a longo prazo (cinco anos pós-tratamento) da instituição do aparelho de Herbst no componente vertical, expresso pelo ângulo SN.GoGn, com especial ênfase na característica individual prétratamento desta mensuração (normo, hipo ou hiperdivergente). Trataram-se 80 pacientes, de ambos os gêneros, que apresentavam más oclusões de Classe II e idade inicial média entre 10 a 14 anos. Os resultados mostraram que, mesmo que suaves diferenças nas mudanças do ângulo tenham sido detectadas durante os dois períodos de examinação (a curto e a longo prazo), nenhuma dessas diferenças foram estatisticamente significantes. Logo, a terapia com o aparelho de Herbst não apresentou um efeito significante no ângulo SN.GoGn, com a abertura inicial compensada durante o tratamento ativo e no período de acomodação póstratamento. Mesmo que esse ângulo não tenha sido afetado pela terapia, houve uma grande variação na resposta individual a curto e a longo prazo. No período póstratamento, a diminuição contínua desse ângulo foi presente em quase todos os pacientes, como resultado da função normalizada que permitiu um crescimento e desenvolvimento normais. Fraca correlação foi observada entre a característica inicial do ângulo do plano mandibular e as alterações angulares observadas durante o tratamento.

Averiguando diversos estudos precedentes com a utilização do aparelho de Herbst, PANCHERZ ${ }^{129}$, em 1997, descreveu alguns efeitos terapêuticos a curto e a longo prazo na oclusão e no complexo maxilomandibular. Durante a sua descrição, o autor dá preferência ao aparelho de Herbst nas correções das más oclusões de Classe II, afirmando ser o tratamento mais efetivo nesses casos e indica esta terapia na dentadura permanente ou logo após o pico de crescimento pubescente, alegando que, na dentadura mista, a dificuldade em se alcançar uma intercuspidação estável após o tratamento facilita o aparecimento de recidivas. Durante os seis primeiros meses de terapia, o autor cita algumas alterações como o aumento do comprimento mandibular, a vestibularização dos incisivos inferiores, a inclinação do plano oclusal para baixo, a inibição do crescimento maxilar, a distalização dos dentes pósterosuperiores, o aumento do ângulo goníaco, e a redução da sobremordida decorrente da intrusão dos incisivos inferiores e da extrusão dos molares inferiores. Verificou-se, também, um efeito limitado na relação entre os maxilares no sentido vertical, 
expresso pelas medidas do plano mandibular e do plano palatino, devido à diminuição continuada dessas medidas durante, bem como após o tratamento nos pacientes que apresentavam tanto crescimento vertical como horizontal inicialmente. Mediante essas características, o autor iguala o efeito do aparelho de Herbst no complexo maxilar ao efeito do aparelho Extrabucal de tração occipital. A longo prazo, as mudanças esqueléticas e dentárias relatadas não se distinguiram do crescimento e desenvolvimento normal dos pacientes controles.

Sendo a maioria dos estudos com a utilização do aparelho de Herbst realizada em pacientes no período pré-pico de crescimento pubescente, KONIK; PANCHERZ; HANSEN ${ }^{89}$, em 1997, decidiram também investigar as alterações dentárias e esqueléticas provenientes deste aparelho em pacientes em período póspico de crescimento que apresentavam más oclusões de Classe II, divisão 1 de Angle. A maturidade esquelética baseou-se nas radiografias carpais, com 21 pacientes (15 do gênero feminino e seis do masculino) tratados tardiamente por 7,7 meses em média e 22 pacientes (três do gênero feminino e 19 do masculino) tratados precocemente por 6,2 meses em média. A relação molar de Classe I foi obtida em todos os pacientes dos dois grupos com o aparelho de Herbst, tipo bandado. Os resultados cefalométricos evidenciaram similares alterações esqueléticas em ambos os maxilares nos dois grupos experimentais, porém com alterações dentárias diferenciadas entre eles. A correção da sobressaliência foi $3,3 \mathrm{~mm}$ a mais nos pacientes tratados pós-pico que nos pacientes pré-pico, devido a movimentos dentários mais extensivos na retrusão dos incisivos superiores e na protrusão dos incisivos inferiores. Pôde-se explicar a reação retrusiva dos incisivos superiores pelo fato de que a ancoragem nesses pacientes foi total, envolvendo todos os dentes do arco dentário superior. Concluíram que o tratamento com o aparelho de Herbst foi igualmente eficiente nos dois períodos de tratamento quanto à correção molar de Classe II. Contudo, o tratamento, quando realizado na dentadura permanente, logo após o pico de crescimento, mostrou-se mais vantajoso, mesmo com a perda de ancoragem exuberante, devido ao estabelecimento oclusal mais favorável e redução no período de contenção.

Em 1998, LAl; McNAMARA JÚNIOR ${ }^{92}$ avaliaram as mudanças dentoesqueléticas promovidas durante a primeira fase terapêutica de más oclusões de 
Classe II, divisão 1 pelo aparelho de Herbst, tipo esplinte de acrílico. Selecionaramse 40 pacientes, sendo 20 do gênero feminino com a idade inicial média de 12,5 anos e 20 pacientes do gênero masculino com a idade inicial média de 13,6 anos. Os resultados demonstraram, após um ano de tratamento ortopédico, uma diminuição estatisticamente significante do ângulo A.N.B, acompanhado pela redução do ângulo S.N.A e o aumento do ângulo S.N.B. A relação molar foi corrigida em média $5,7 \mathrm{~mm}$ e a sobressaliência, em média 4,5mm. O comprimento mandibular, representado pela medida Go-Gn, aumentou de modo significante $4,7 \mathrm{~mm}$ em média e as alturas faciais anterior e posterior também aumentaram significantemente, não influenciando, por conseguinte, o ângulo do plano mandibular. Como não se constatou aumento significante na altura facial ântero-inferior, o crescimento diagnosticado na altura facial anterior foi atribuído ao aumento da altura facial ântero-superior. Explicou-se este achado à rotação exercida no plano palatino no sentido horário, devido à ação do aparelho no sentido póstero-superior na região posterior da maxila. O plano oclusal também foi influenciado com essa mecanoterapia, aumentando-o devido à restrição da erupção dos molares superiores e incisivos inferiores e o aumento da altura alveolar inferior, em decorrência da erupção estimulada dos molares inferiores. O aparelho de Herbst induziu a distalização dos molares superiores e a mesialização dos dentes inferiores; contudo, não interferiu na posição dos incisivos superiores. Os autores concluíram que a correção da Classe II, nos pacientes tratados com o aparelho de Herbst, foi em decorrência da combinação de vários fatores, incluindo mudanças esqueléticas e dentárias.

Utilizando como métodos de análise a ressonância magnética e a radiografia de perfil convencional, RUF; PANCHERZ ${ }^{167}$, em 1998, analisaram os três possíveis mecanismos de adaptação da junção temporomandibular (remodelação condilar, remodelação da fossa glenóide e mudanças no relacionamento côndilofossa) quando da projeção mandibular com o aparelho de Herbst. Quinze pacientes, quatro do gênero feminino e 11 do masculino, com más oclusões de Classe II na dentadura permanente compuseram a amostra experimental. A idade inicial média e o tempo de tratamento médio foram de 13,5 anos e sete meses respectivamente e o aparelho de escolha foi o tipo esplinte metálico. Registraram-se, pela ressonância magnética, que os côndilos no início da terapia foram avançados, em direção anterior, em 15 pacientes, enquanto que em seis a 12 semanas de terapia, os 
côndilos apresentavam-se parcialmente reposicionados em direção posterior na fossa glenóide; a quantidade de adaptação da fossa glenóide mostrou-se menor que o processo de remodelação do côndilo; e a posição condilar foi praticamente inalterada pela terapia, porém com grande variação individual. O crescimento condilar efetivo, estudado nas radiografias em norma lateral dos pacientes experimentais e comparados com pacientes portadores de oclusão ideal, mostrou-se em média seis vezes maior na direção horizontal e quatro vezes maior na direção vertical. De forma geral, os autores concluíram que a obtenção do prognatismo mandibular com o aparelho de Herbst pareceu ser, em particular, um resultado do remodelamento do côndilo, bem como da fossa glenóide, enquanto que as mudanças no relacionamento côndilo-fossa foram de menor importância.

Também no ano de 1998, PANCHERZ; RUF; KOHLHAS ${ }^{141}$ analisaram o crescimento condilar efetivo (somatório das remodelações condilar e da fossa glenóide, com a alteração da posição condilar no interior da fossa) e a sua influência na posição do mento, em pacientes tratados com o aparelho de Herbst, tipo bandado. O grupo experimental, com más oclusões de Classe II, foi composto por 59 pacientes do gênero masculino e 39 do feminino e o grupo controle, apresentando oclusões ideais, por 16 pacientes do gênero masculino e 16 do feminino. A análise de radiografias, em norma lateral, permitiu mostrar uma grande influência do tipo de rotação mandibular na direção das alterações da posição do mento. Nos casos com rotação mandibular em sentido anterior, o mento movimentou-se, relativamente, mais para a anterior e nos casos com rotação posterior, o mento movimentou-se mais para a inferior. Em sete meses de tratamento, o crescimento condilar efetivo foi direcionado em sentido posterior, três vezes mais que o encontrado no grupo controle, resultando na movimentação do mento em sentido anterior e inferior. $O$ componente vertical aumentado na posição do mento, em comparação com a alteração condilar, foi certamente o resultado da rotação mandibular em sentido horário, com o avanço mandibular para uma relação de topo dos incisivos.

No ano seguinte, RUF; PANCHERZ ${ }^{168}$ investigaram cefalometricamente as mudanças dento-esqueléticas e do perfil mole em uma nova amostra compreendida por pacientes com más oclusões de Classe II de Angle, tratados também com o mesmo tipo de aparelho. O grupo experimental compreendeu 14 
jovens, 10 do gênero feminino e quatro do masculino, no final do período de crescimento pubescente. Para fins comparativos, escolheram-se 25 adolescentes, sendo 12 deles pertencentes ao gênero feminino e 13 do masculino, tratados anteriormente com o aparelho de Herbst durante o pico máximo de crescimento pubescente. A idade inicial média e o tempo de tratamento médio foram de 16,5 anos e 8,5 meses respectivamente para o grupo experimental e 12,8 anos e 7,1 meses para o grupo controle. A análise cefalométrica compreendeu 16 mensurações, seguindo o mesmo protótipo de análise estabelecido por Pancherz ${ }^{126}$. No final do período terapêutico, com a relação molar corrigida clinicamente, os autores verificaram que, em ambos os grupos, a convexidade facial (tecido duro e mole) foi significantemente reduzida, não mostrando diferença entre as fases de maturidade estudas. A melhora na oclusão no sentido ântero-posterior (correção da sobressaliência e da relação molar) foi alcançada mais por mudanças dentárias do que esqueléticas em ambos os grupos; contudo, o fator esquelético (visto pelo aumento no comprimento mandibular e pelo avanço da base mandibular) foi mais pronunciado no grupo composto por adolescentes, em decorrência da maior velocidade de crescimento mandibular. No grupo composto por jovens, a maior quantidade de mudança dentária ocorreu na mandíbula (mesialização dos molares e vestibularização dos incisivos), compensando a menor resposta esquelética. Mesmo assim, observou-se um aumento no comprimento mandibular nesse grupo experimental, atribuindo-o a possível reativação das células da região precondroblástica e na mecânica fixa do aparelho - avanço mandibular contínuo sem a necessidade da colaboração do paciente. Quanto ao avanço da base apical inferior, os autores discutem um leque de explicações alternativas a este achado, que vai desde o deslocamento do côndilo no interior da fossa até uma possível remodelação da cavidade glenóide. O trabalho conclui que é possível alcançar ótimas adaptações dentofaciais em jovens com a utilização do aparelho funcional fixo, oferecendo uma alternativa à cirurgia ortognática em casos limites de Classe II.

No ano de $1999^{169}$, os mesmos autores utilizaram a ressonância magnética e a telerradiografia para investigar e comparar os mecanismos temporomandibulares adaptativos em adolescentes e adultos, que apresentavam a má oclusão de Classe II, tratados com o aparelho de Herbst. Selecionaram-se 25 adolescentes (12 do gênero feminino e 13 do masculino) com a idade inicial média 
de 12,8 anos e 14 adultos (10 do gênero feminino e quatro do masculino), com a média de 16,5 anos, sendo diferenciados pela maturidade esquelética. Os pacientes adultos se encontravam no final do período de crescimento pubescente, com mínimo ou nenhum crescimento residual, enquanto que os adolescentes se encontravam em fase de aceleração do pico de crescimento pubescente. O aparelho de escolha foi o do tipo esplinte metálico, com o avanço mandibular numa relação de topo entre os dentes anteriores e o tempo de tratamento médio foi de 7,1 e 8,5 meses para os adolescentes e adultos, respectivamente. Todos os pacientes foram corrigidos para uma relação molar de Classe I ou sobrecorrigidos. Em seis a 12 semanas de tratamento $\left(T_{2}\right)$, até o final do período experimental $\left(T_{3}\right)$, sinais de alteração em nível condilar, na região póstero-superior, foram evidentes e persistentes nos pacientes adultos, enquanto que nos adolescentes, esses sinais de alteração se encontravam em seu potencial máximo em $T_{2}$, porém se declinaram em $T_{3}$. De antemão, concluiuse que uma resposta expressiva de crescimento condilar pôde ser evidenciada em todos os pacientes adultos tratados com o aparelho funcional. A remodelação da fossa glenóide, ao longo de sua superfície anterior, em resposta à função mandibular alterada, ocorreu em estágio de tratamento tardio em relação à remodelação condilar. Em ambos os grupos de diferentes estágios de maturidade esquelética, esta remodelação se mostrou mais intensa na região inferior da borda anterior da espinha pós-glenoidal. Essa nova formação óssea pareceu ser induzida por forças tensivas do tecido fibroso posterior do disco articular transmitido ao periósteo. Os autores concluíram que o prognatismo mandibular acompanhado pela terapia funcional fixa em ambos os tipos de pacientes, adolescentes e adultos, parece ser um resultado de remodelação conjunta do côndilo e da fossa glenóide e que esse tratamento pode ser um método alternativo à cirurgia ortognática, com excelentes resultados em pacientes adultos, adicionado ao fato que a articulação temporomandibular é capaz de se adaptar nessas condições.

FRANCHI; BACCETTI; McNAMARA JÚNIOR ${ }^{50}$, em 1999, descreveram alguns requerimentos, de particular interesse, ao se investigarem os efeitos no complexo craniofacial com a utilização dos aparelhos ortopédicos funcionais em pacientes em fase de crescimento. Entre eles, citaram-se: 1- a utilização de indicadores da maturidade esquelética (radiografias carpais; curvas de velocidade de crescimento em altura corporal; estágio do desenvolvimento da vértebra cervical); 2- 
a disponibilidade de grupos controles para a avaliação estatística dos efeitos do tratamento nos pacientes submetidos à terapêutica preconizada (grupos homogêneos quanto à raça, gênero, idade, tipo de má oclusão, estágio de maturidade esquelética e padrão craniofacial nos diferentes estágios de avaliação); e 3- a avaliação das mudanças pós-tratamento. Em seguida, expuseram um estudo realizado com o aparelho de Herbst, tipo esplinte de acrílico, tentando seguir os parâmetros citados anteriormente na elaboração do trabalho, no intuito de verificar os efeitos a curto e a longo prazo desse tipo de tratamento em pacientes com a idade inicial média de 12,8 anos. Após a obtenção dos resultados, constataram que 2/3 da correção oclusal, alcançada em um ano de tratamento, foram em decorrência dos efeitos esqueléticos e apenas 1/3 das adaptações dento-alveolares, sendo ambos os efeitos esqueléticos e dento-alveolares ocorridos principalmente nas estruturas mandibulares. A quantidade de recidiva na relação molar, diagnosticada póstratamento (média de dois anos após a remoção dos aparelhos), pôde ser atribuída à mesialização dos molares superiores.

No mesmo ano, CROFT; BUSCHANG; ENGLISH; MEYER ${ }^{39}$ investigaram os efeitos no complexo dentofacial e na articulação temporomandibular oriundos da terapia ortopédica com o aparelho de Herbst, instituído na dentadura mista. Selecionaram-se 24 pacientes do gênero feminino e 16 do masculino submetidos inicialmente à expansão rápida da maxila, em seguida ao avanço mandibular, com o aparelho de Herbst com cantiléver, por um período de 11 meses, e finalizando-se com uma fase de contenção por tempo médio de 17 meses. Selecionou-se um grupo controle pareado ao experimental quanto à idade, gênero e mensuração do ângulo do plano mandibular. A idade inicial média, ao se instalar o aparelho de Herbst, foi de 9,4 anos. Os resultados tomográficos e cefalométricos, da terapia com o aparelho de Herbst, na dentadura mista, seguida por um período de contenção, mostraram uma significante correção da má oclusão de Classe II, com efeitos dentários e ortopédicos, que se mantiveram durante o período de transição da dentadura. 0 ângulo S.N.A e o A.N.B foram diminuídos em $0,9^{\circ}$ e $1,9^{\circ}$ respectivamente e o ângulo S.N.B aumentado em $1,0^{\circ}$. O efeito ortopédico maxilar foi observado com a restrição do deslocamento do ponto A em 1,2mm. A associação da distalização dos dentes superiores com a mesialização dos dentes inferiores favoreceu a correção da relação molar e da sobressaliência. O efeito ortopédico mandibular resultou num 
redirecionamento (expressivo no sentido posterior) e não num aumento do crescimento condilar, dando suporte ao conceito que os efeitos do tratamento no crescimento sagital condilar é idade dependente. Verificou-se que a posição condilar, no interior da fossa mandibular, não é afetada pelo tratamento, não atribuindo os efeitos do tratamento a uma posição mandibular mais anteriorizada. Concluiu-se que o tratamento efetuado na dentadura mista com o aparelho de Herbst, seguido por um período de contenção, resulta em melhores condições de relacionamento esquelético e dentário em pacientes que apresentavam más oclusões de Classe II, sendo uma opção viável de tratamento.

CRUZ; HENRIQUES; DAINESI; JANSON ${ }^{40}$, em 2000, investigaram a literatura sobre os mecanismos de ação e os efeitos ortopédicos e ortodônticos no complexo craniofacial de cinco diferentes tipos de aparelhos funcionais na correção da má oclusão de Classe II, divisão 1. Entre as diversas modalidades terapêuticas estudadas com afinco, os autores verificaram que o aparelho de Herbst, durante a fase de crescimento ativo do paciente, estimula algumas alterações dentoesqueléticas inerentes à mecânica, tais como: restrição do crescimento maxilar, aumento no comprimento mandibular (Co-Gn), aumento da AFAl e vestibularização dos incisivos inferiores. Atribuíram ao avanço mandibular contínuo e à restrição do crescimento maxilar, a melhora significante da relação maxilomandibular e do perfil facial. Com relação ao componente dento-alveolar, concluíram que a mecânica restringe a erupção bem como distaliza os molares superiores e o avanço contínuo da mandíbula contribui para a mesialização e a extrusão dos molares inferiores; perceberam uma certa divergência entre as publicações consultadas, quanto às alterações no posicionamento dos incisivos superiores. As desvantagens do aparelho de Herbst enquadraram-se na excessiva vestibularização dos incisivos inferiores, no aumento do ângulo goníaco, além da necessidade de um período de contenção, póstratamento, com o aparelho funcional Ativador.

No mesmo ano, URSI; McNAMARA JÚNIOR; MARTINS; URSI ${ }^{192}$, realizaram um estudo cefalométrico em telerradiografias, objetivando determinar o efeito no perfil tegumentar de pacientes apresentando más oclusões de Classe II, tratados com os aparelhos Extrabucal de tração cervical, Fränkel e Herbst. Os grupos experimentais e controle, bem como a metodologia aplicada, foram iguais ao trabalho 
anterior de autoria do primeiro autor, divergindo apenas com relação às grandezas cefalométricas utilizadas. Ao final do período experimental, todos os aparelhos tiveram um efeito positivo sobre a convexidade facial. Ficou evidente uma discreta redução na projeção dos lábios superiores em todos os grupos, sendo o ângulo nasolabial mais influenciado no grupo tratado com o aparelho Extrabucal com um significativo aumento, enquanto que o aparelho de Fränkel determinou a maior verticalização do lábio superior. Já o lábio inferior foi mais protruído pela ação do aparelho de Herbst. Ficou evidente que cada um desses aparelhos afeta o perfil tegumentar de maneira específica e que a indicação de um ou outro deve levar em consideração o arranjo inicial de cada paciente.

Com o propósito de determinar os efeitos exclusivos do tratamento com o aparelho de Herbst e de verificar se o gênero influencia ou não a resposta a este tipo de tratamento, MANFREDI; CIMINO; TRANI; PANCHERZ ${ }^{96}$, em 2001, utilizaram uma amostra experimental retrospectiva de 25 pacientes do gênero masculino, entre 10,7 a 14,5 anos e 25 pacientes do gênero feminino, entre 10,7 a 14,3 anos, com más oclusões de Classe II, divisão 1, tratados por um tempo médio de seis a oito meses. Com a obtenção dos resultados, constataram que o tão falado efeito esquelético de tração occipital do aparelho de Herbst sobre a maxila não se mostrou pronunciado, e que apenas os meninos mostraram uma rotação da maxila no sentido horário. Também neste gênero, observou-se um crescimento mais pronunciado da mandíbula, especificamente na borda posterior do ramo mandibular. A mandíbula apresentou-se protruída de modo significante, diminuindo o ângulo A.N.B em ambos os gêneros. Os autores apoiaram as hipóteses de que a morfologia mandibular está sob forte controle genético enquanto que a dimensão e a posição são mais susceptíveis à influência ortodôntica. Concluiu-se que o aparelho de Herbst influencia a base apical superior, no sentido sagital e vertical, nos pacientes do gênero masculino, e que o reposicionamento anterior da mandíbula, bem como o aumento no comprimento mandibular foram modificados em quase toda a amostra.

Em 2002, MORO; FUZIY; FREITAS; HENRIQUES; JANSON ${ }^{116}$ descreveram detalhadamente os passos clínicos para a utilização do aparelho de Herbst com cantiléver - CBJ ("Cantilever Bite-Jumper"). A abordagem do texto englobou desde o melhor candidato ao avanço anterior da mandíbula por meio deste 
aparelho à sua remoção. Concluíram que, com o desenvolvimento do CBJ, a utilização clínica do aparelho de Herbst foi facilitada, permitindo que o ortodontista atual disponha, dentro do seu arsenal terapêutico ortopédico, de um aparelho resistente, eficiente e que promove resultados previsíveis.

No mesmo ano, DU; HÄGG; RABIE $^{44}$ compararam a efetividade do tratamento da má oclusão de Classe $\mathrm{II}$, divisão 1 entre duas modalidades terapêuticas de controle maxilar e de avanço mandibular. Para tanto, empregou-se o aparelho de Herbst com ou sem a associação do aparelho Extrabucal e com o avanço mandibular realizado de forma gradual versus de forma única. O material da amostra compôs-se de telerradiografias obtidas ao início e ao final do tratamento, de pacientes chineses, dividido em dois grupos experimentais. O primeiro grupo formado por 21 pacientes (oito do gênero masculino e 13 do feminino), com a idade inicial média de 13,3 anos, submetidos ao uso do aparelho de Herbst (tipo esplinte) associado ao uso do aparelho Extrabucal, com o avanço mandibular realizado de forma gradual, por tempo médio de tratamento de 12 meses. O segundo grupo formado por 24 pacientes (12 do gênero masculino e 12 do feminino), com a idade inicial média de 13,2 anos, submetidos ao uso do aparelho convencional de Herbst (tipo bandado acoplado a um parafuso expansor no palato para o aumento de ancoragem e aumento transversal quando necessário), com o avanço mandibular realizado de forma única, por tempo médio de tratamento de 10 meses. No primeiro grupo, a tração extrabucal foi utilizada 12 horas por dia, com uma força de 400-500 gramas por lado e a reativação de $2 \mathrm{~mm}$ conduzida a cada dois meses. $\mathrm{O}$ relacionamento dentário interarcos foi alterado para Classe I ou III, no final do período experimental nos dois grupos. Os resultados cefalométricos mostraram que o efeito do avanço mandibular gradual na posição sagital mandibular foi maior que o efeito do avanço mandibular único. Enfatizou-se que a resposta do crescimento condilar é melhorada quando a mandíbula é reposicionada anteriormente de maneira passo a passo. Adicionalmente, com o avanço gradual, o ângulo do plano mandibular foi fechado de maneira estatisticamente significante, com subseqüente rotação mandibular em sentido anti-horário, favorecendo a posição do pogônio para a anterior, em comparação ao outro grupo, em que o pogônio foi conduzido para posterior. Uma outra razão que diferenciou a rotação do ângulo do plano mandibular entre os grupos foi a intrusão dos molares superiores com o avanço gradual, 
provavelmente devido ao uso do aparelho Extrabucal neste grupo. Restringiu-se o crescimento anterior da maxila no primeiro grupo, demonstrando ser a tração Extrabucal uma ferramenta efetiva no controle do crescimento maxilar durante a terapia com o aparelho de Herbst em adolescentes com más oclusões de Classe II. A melhora no relacionamento sagital maxilomandibular foi duas vezes maior no primeiro grupo, pois se associou à restrição do crescimento maxilar e ao maior avanço mandibular. As alterações dentárias foram, em geral, similares entre os grupos, sem redução da perda de ancoragem dentária com o avanço mandibular gradual, porém com efeitos mais pronunciados na distalização e intrusão dos primeiros molares superiores quando da utilização do aparelho Extrabucal. Concluiuse que o aparelho de Herbst associado à tração extrabucal, com o avanço mandibular realizado de forma gradual, mostrou ter grande influência no relacionamento sagital mandibular, com controle vertical melhorado e com movimentos mais expressivos dos molares superiores.

Com o firme propósito de aquietar a dúvida quanto ao período ideal para a estimulação máxima do crescimento mandibular e estabilidade a longo prazo com o aparelho de Herbst nas correções de más oclusões de Classe II, RUF; PANCHERZ ${ }^{170}$, em 2003, revisaram e reuniram atentamente trabalhos pertinentes da literatura disponível. Mediante todos os resultados e discussões dos trabalhos científicos selecionados, os autores foram direcionados a um novo conceito de tratamento das más oclusões de Classe II, que se segue: modificação do crescimento em crianças, em adolescentes, em pós-adolescentes e em adultos jovens, e a camuflagem ortodôntica e a cirurgia ortognática em pacientes adultos. Chegou-se a essa opinião, quanto ao tratamento favorecido em fases mais avançadas, devido aos estudos relatarem que em adultos jovens, o crescimento condilar e da fossa mandibular podem ser reativados e alterados favoravelmente; em média, $22 \%$ das mudanças esqueléticas contribuem para a correção da sobressaliência; e alterações comparáveis no relacionamento sagital das bases ósseas e no perfil esquelético são detectadas com a terapia ortopédica fixa e com a cirurgia ortognática. Concluiu-se que o período ideal para a aplicação do aparelho de Herbst é na dentadura permanente, durante ou logo após o surto de crescimento pubescente e que nessa fase os pacientes apresentam um mínimo de crescimento 
residual capaz de comprometer os resultados alcançados, favorecendo a estabilidade a longo prazo.

Interessados nos efeitos dento-esqueléticos, especialmente sobre a maxila, obtidos com a utilização do aparelho de Herbst associado ou não ao aparelho Extrabucal, HÄGG; DU; RABIE; BENDEUS ${ }^{61}$, em 2003, compilaram uma amostra de 36 jovens, apresentando más oclusões esqueléticas de classe II. Um grupo experimental compôs-se de 22 pacientes tratados com as duas mecanoterapias simultaneamente e com o aparelho Ativador associado ao Extrabucal como contenção pós-tratamento e um outro grupo, pareado quanto à idade e morfologia dentofacial, compôs-se de 14 pacientes tratados apenas com o aparelho de Herbst e com o aparelho Ativador de Andresen como contenção. Obtiveram-se cefalogramas laterais ao início do tratamento, após seis meses, após 12 meses (final do tratamento) e após seis meses de contenção. O aparelho de Herbst escolhido foi o do tipo esplinte metálico, com o avanço mandibular gradual (2mm a cada dois meses). Quando da associação com o Extrabucal, preconizou-se uma força aproximada de 400 a 500 gramas de cada lado, com o braço externo angulado a $30^{\circ}$ do plano oclusal. Ao finalizar os tratamentos em 12 meses, os resultados apontaram que, no grupo com a tração occipital associada, o relacionamento basal dos maxilares no sentido sagital foi melhor que no grupo sem a tração, devido à restrição do crescimento maxilar $(-0,6 \mathrm{~mm})$ e maior crescimento mandibular. Com a tração, os incisivos inferiores também protruíram menos. Já no grupo sem a tração, a maxila cresceu anteriormente $1,1 \mathrm{~mm}$. Em 18 meses de tratamento total (incluindo o período de contenção), $70 \%$ da correção da sobressaliência no grupo com o aparelho Extrabucal decorreram das alterações esqueléticas e no grupo sem a associação da tração, apenas 30\% (as alterações foram mais dentárias que esqueléticas). Concluiuse que a adição da tração occipital no tratamento das más oclusões esqueléticas de Classe II com o aparelho de Herbst, com um avanço mandibular gradual, contribuiu para resultados mais positivos e que o Ativador de Andresen não pareceu ser apropriado como contenção após a terapia com o aparelho ortopédico fixo.

BURKHARDT; McNAMARA JÚNIOR; BACCETTI ${ }^{29}$, em 2003, compararam detalhadamente os efeitos do tratamento das más oclusões de Classe II entre os aparelhos de Herbst (um grupo tratado com o tipo esplinte de acrílico e outro tratado 
com o tipo bandado ou com o cantiléver) e o Pêndulo, ambos seguidos pela aparelhagem fixa, com o intuito de determinar as diferenças morfológicas no final do tratamento total. Cefalometricamente, os dados revelaram que não houve diferença significante no aumento do comprimento mandibular e na redução do ângulo A.N.B entre os três grupos. Entretanto, o grupo submetido ao tratamento com o aparelho Pêndulo apresentou menor quantia de avanço mandibular, identificada pela medida S.N.B. O ângulo do plano mandibular abriu suavemente no grupo com o Pêndulo, enquanto que, nos grupos com o Herbst, fechou suavemente. Os molares superiores foram distalizados e inclinados com o Pêndulo, enquanto que os molares superiores foram mantidos em suas posições originais no sentido sagital ou ligeiramente mesializados com o Herbst. A protrusão e a vestibularização dos incisivos inferiores, bem como a mesialização dos molares inferiores, foram evidenciados em todos os grupos, embora a mesialização dos molares tenha sido suavemente mais expressiva com o aparelho de Herbst tipo bandado. Quanto à erupção dentária, não houve diferença entre os três grupos. Com relação ao perfil facial tegumentar, observou-se também em todos os grupos uma tendência retrusiva dos lábios em relação à linha E. Os autores se surpreenderam com os dados obtidos, pois esperavam efeitos mais diferenciados entre os aparelhos. Concluíram que o Pêndulo corrigiu a Classe II principalmente por movimentos dentários e o aparelho de Herbst, por alterações dentárias (50\%) e esqueléticas (50\%).

\subsubsection{Evidências Experimentais em Animais}

Dando suporte às pesquisas clínicas, a utilização de animais de laboratórios em experimentos científicos sempre esteve presente nos arquivos literários das diversas especialidades odontológicas. Com o objetivo de auxiliar a interpretação de resultados alcançados com os aparelhos ortopédicos funcionais em humanos, relatar-se-ão uma série de trabalhos utilizando macacos e ratos em que os efeitos temporomandibulares e dento-esqueléticos da protrusão mandibular foram avaliados. 


\subsubsection{Protrusão Mandibular e Crescimento Condilar}

Dúvidas, quanto à real influência de estímulos ortopédicos (fatores extrínsecos) sobre a cartilagem condilar, estimularam BAUME; DERICHSWEILER ${ }^{11}$, em 1961, a investigarem, em quatro macacas, os possíveis efeitos temporomandibulares da protrusão mandibular forçada. As duas primeiras macacas serviram como animais controles, enquanto que as demais como animais experimentais, com a idade inicial média entre 44 a 50 meses nos dois últimos animais. Sacrificaram-se a terceira e a quarta macaca após dois meses e meio e após quatro meses e meio de tratamento, respectivamente. Os resultados cefalométricos mostraram um deslocamento anterior da mandíbula, enquanto que os resultados histológicos mostraram uma proliferação aumentada da cartilagem e uma ativa ossificação endocondral, principalmente na região posterior do côndilo. Observou-se uma reabsorção óssea na parede anterior da fossa mandibular, porém detectada apenas em nível microscópico. Todas essas características foram mais acentuadas na segunda macaca experimental, com o tempo maior de experimento. Os autores concluíram que a cartilagem condilar, com o seu crescimento endocondral, responde à terapia funcional.

CHARLIER; PETROVIC; HERRMANN-STUTZMANN ${ }^{34}$, em 1969, estudaram os efeitos da protrusão mandibular em ratos, com auxílio de um dispositivo fixo, em que os incisivos inferiores mantiveram-se à frente dos superiores 24 horas por dia. Para tanto, estabeleceram-se dois grupos, um experimental e o outro controle, com aproximadamente 24 componentes em cada, que apresentavam na época quatro semanas de vida. Após quatro semanas de experimento, os achados histológicos mostraram uma espessura aumentada do disco articular e um significante aumento da zona pré-condroblástica, com uma proliferação celular aumentada. Mediante esses resultados, concluíram que a protrusão mandibular forçada em ratos, a curto prazo, estimula as células da zona pré-condroblástica, contribuindo com um adicional crescimento cartilaginoso condilar.

Em 1971, RAMFJORD; ENLOW ${ }^{154}$ pesquisaram, em três macacas adultas, entre 10 a 15 anos de idade, o deslocamento anterior mandibular contínuo (avanço de 1,5mm) por um aparelho ortopédico fixo, tipo esplinte metálico em ouro, 
envolvendo o máximo número de dentes possível (excluindo apenas os incisivos superiores) e por um período longo de tempo (sacrifícios: após 1,5 ano; 2 anos e 3 anos). Baseados em análises clínicas, radiográficas e histológicas, verificaram que, ao se compararem os dados provenientes do grupo experimental com os de um grupo controle composto por 10 animais, os dentes inferiores mesializaram em relação aos superiores e que as acomodações ou alterações adaptativas da oclusão ocorreram em virtude de reposicionamentos dentários e não de alterações funcionais na articulação temporomandibular. As estruturas temporomandibulares das macacas adultas mostraram-se muito resistentes às forças aplicadas, não evidenciando alterações categóricas, enquanto que mudanças dentárias foram, grosso modo, evidenciadas. Concluiu-se, desta forma, que respostas temporomandibulares adaptativas ao posicionamento anterior da mandíbula não podem ser esperadas.

Nesse mesmo ano, STÖCKLI; WILLERT ${ }^{183}$, no intuito de esclarecer as reações na articulação temporomandibular em decorrência do deslocamento anterior da mandíbula durante o período de crescimento, selecionaram oito macacos (Macaca irus) com idades variando de 38 a 45 meses, sendo essas comparáveis à idade humana de oito a 10 anos. Dois desses animais serviram como controle e a amostra experimental foi composta de seis animais que foram submetidos a um avanço mandibular forçado em $5 \mathrm{~mm}$ com a cimentação de esplintes metálicos em ouro nos arcos superior e inferior. As características histológicas mostraram que, nos animais controles, nenhuma alteração foi detectada dentro de sua normalidade, enquanto que, nos animais experimentais, observou-se um alargamento excessivo da cartilagem condilar na região posterior, em 25 dias de experimento, com uma atividade proliferativa celular aumentada. A porção temporal da articulação, para restituir a relação original côndilo-fossa, mostrou uma reação tecidual com alto potencial condroblástico. Sugeriram, mediante a obtenção de todos os dados, as seguintes conclusões: a articulação temporomandibular, durante o período de crescimento em animais, revelou uma alta capacidade de adaptação ao deslocamento mandibular anterior, ortopedicamente induzido, com uma resposta tecidual compensatória no côndilo e fossa no restabelecimento topográfico da articulação; e a resposta tecidual pôde ser iniciada após um período curto de tempo de deslocamento mandibular (25 dias), porém de caráter transitório. 
ELGOYHEN; MOYERS; McNAMARA JÚNIOR; RIOLO ${ }^{46}$, em 1972, estudaram os efeitos decorrentes do deslocamento mandibular funcional em 16 macacos (Macaca mulatta), apresentando uma idade cronológica de aproximadamente 20 a 24 meses, correspondendo à idade humana de seis a oito anos. Adaptaram-se, em apenas seis macacos, um aparelho compreendido por uma estrutura metálica em ouro que posicionava continuamente a mandíbula numa posição mais anterior. Utilizou-se a cefalometria associada a implantes, com tomadas radiográficas mensais, para a avaliação dos resultados. Clinicamente, em três meses de experimento, os macacos com o aparelho exibiram um prognatismo mandibular enquanto que, em cinco meses, após a retirada deste, uma relação molar de Classe III. Cefalometricamente, após três meses de terapia, o único achado significante entre os grupos foi o aumento das medidas condilares, quanto à velocidade e extensão de crescimento, enquanto que, em cinco meses, observou-se uma mesialização significante dos dentes póstero-inferiores e uma inibição do desenvolvimento sagital e vertical dos dentes pôstero-superiores. A mandíbula apresentou-se mais protruída em relação à base do crânio e a maxila mostrou um redirecionamento do padrão de crescimento, com um vetor de crescimento mais para a anterior do que para a inferior. Concluíram que a relação maxilomandibular pode ser alcançada em macacos jovens com a alteração forçada postural do osso mandibular e que as mudanças esqueléticas são mais expressivas nos primeiros meses de terapia, necessitando de reativações periódicas para maiores efeitos esqueléticos.

No mesmo ano, ADAMS; MEIKLE; NORWICK; TURPIN ${ }^{1}$ investigaram os efeitos da protrusão mandibular, com esplintes metálicos em ouro associados a elásticos intermaxilares, em quatro macacos com uma idade média, equivalente à idade humana, entre cinco a oito anos (dois macacos) e por volta dos 20 anos de idade (outros dois macacos). Após longo período de experimento, todos os animais desenvolveram uma relação molar de Classe III, com uma aparência prognata no final do período. Tomadas radiográficas em norma lateral, associadas à colocação de implantes metálicos, revelaram alterações no complexo dentofacial com uma rotação no sentido horário da maxila e um deslocamento mandibular em sentido anterior. Em decorrência das alterações da maxila no sentido vertical, a mandíbula sofreu o mesmo tipo de rotação, bem como o plano oclusal, sendo este último associado à 
extrusão dos dentes ântero-superiores e intrusão dos inferiores. Os resultados histológicos mostraram que, nos animais mais novos, a ossificação endocondral, nos côndilos mandibulares, mostrou estar mais direcionada em sentido posterior do que em condições normais e a forma do côndilo pareceu ser menos circular. Não se observou remodelação articular induzida nesse período de tratamento; contudo, o inverso ocorreu em animais mais velhos com mudanças histológicas na eminência articular, a qual foi comprimida pelo côndilo.

McNAMARA JÚNIOR; CARLSON ${ }^{104}$, em 1979, propuseram quantificar histologicamente as respostas adaptativas temporomandibulares, em macacos jovens, mediante a alteração da posição funcional da mandíbula para a anterior. Vinte e oito macacos (Macaca mulatta), entre 18 e 24 meses de idade, foram alvos da pesquisa, divididos em dois grupos, experimental e controle, com 14 componentes cada. Utilizaram-se esplintes metálicos para o avanço mandibular em $4 \mathrm{~mm}$. Os resultados histológicos revelaram que a camada articular não se mostrou influenciada com a alteração postural mandibular. Contudo, alterações adaptativas significantes, na camada cartilaginosa sub-articular do côndilo, foram evidentes em todos os animais. Considerável hiperplasia da camada cartilaginosa précondroblástica-condroblástica foi particularmente notável na região posterior do côndilo, sendo a espessura três vezes maior que em animais controles, do início do experimento (duas semanas) até a $12^{a}$ semana pós-tratamento. Alterações na morfologia óssea da espinha pós-glenoidal foram também evidentes nos animais experimentais. Os resultados indicaram que a protrusão funcional da mandíbula, em animais em fase de crescimento, conduzem a uma adaptação imediata da cartilagem de crescimento resultando no espessamento da camada pré-condroblásticacondroblástica, bem como um aumento na deposição óssea ao longo da borda posterior do ramo, imediatamente abaixo da cartilagem condilar. As adaptações se mostraram, também, tempo-dependentes. Em 24 semanas de experimento, a espessura da camada sub-articular nos animais experimentais não pôde ser distinguida dos animais controles.

Um dos primeiros trabalhos científicos a estudar os efeitos do aparelho de Herbst na articulação temporomandibular foi em 1983, realizado por METAXAS ${ }^{111}$. Utilizaram-se nove macacos (sete - Macaca fascicularis e dois - Macaca mulatta), 
sendo os sete pertencentes ao grupo experimental e os dois ao grupo controle (sem ativações sucessivas). Apenas um macaco foi classificado como jovem (de 24 a 36 meses), cinco como adolescentes (de 36-48 meses) e um, adulto (de 70 a 80 meses). O aparelho de Herbst utilizado nessa pesquisa caracterizou-se por um mecanismo telescópico em cada um dos lados dos maxilares inserido a uma base metálica de cromo-cobalto. A base metálica englobava a superfície vestibular e lingual de todos os dentes inferiores e a superfície vestibular e palatina dos dentes póstero-superiores. O pistão telescópico era conectado à base metálica na região do primeiro molar superior e o tubo, à base metálica na região do primeiro pré-molar inferior. Ativava-se o mecanismo em passos progressivos com a utilização de pequenos stops (1-2mm). Adicionalmente, colocaram-se implantes metálicos nos componentes da amostra para melhor acuracidade nas aferições cefalométricas. A seqüência das tomadas radiográficas procedeu-se nos seguintes tempos: início do período experimental; após certas ativações em intervalos pré-selecionados; final do período experimental e pós-tratamento (em seguida à remoção dos aparelhos). As alterações averiguadas na articulação temporomandibular indicaram que esta estrutura é altamente plástica e capaz de responder ativamente ao avanço mandibular gradual. A má oclusão de Classe III foi desenvolvida em todos os animais experimentais em seis a 12 semanas, apresentando os fatores de maior contribuição como a restrição do crescimento maxilar, o movimento distal dos dentes superiores, o movimento mesial dos dentes inferiores, algum crescimento condilar (para dois animais somente), o deslocamento para a anterior da mandíbula e o controle da dimensão vertical.

Ao investigar a literatura, envolvendo experimentos em animais, WOODSIDE; ALTUNA; HARVOLD; HERBERT; METAXAS ${ }^{208}$, em 1983, concluíram que a alteração crônica ou contínua da posição mandibular, influenciada pelo ambiente neuromuscular, produz uma remodelação condilar extensa; a rotação da mandíbula para inferior e para posterior pode produzir grandes incrementos no comprimento mandibular, e que atividade muscular acima de certos limites pode interferir na remodelação óssea.

A adaptabilidade da articulação temporomandibular, em condições de protrusão mandibular forçada, foi verificada em 12 macacos adultos (Macaca 
mulatta), entre cinco e seis anos de idade, por HINTON; McNAMARA JÚNIOR ${ }^{77}$, em 1984. Utilizou-se um aparelho fixo, com um avanço programado da mandíbula em $5 \mathrm{~mm}$ no grupo experimental, enquanto que um grupo controle, composto por sete animais, não sofreu intervenção ortopédica. Os dados histológicos após duas, quatro, seis, oito, doze e vinte e quatro semanas mostraram uma diversidade nas respostas temporomandibulares, sendo atribuídos às diferenças na idade cronológica. Os macacos mais velhos não exibiram reações notáveis ao se compararem com os mais novos que exibiram, supondo-se que o número bem como a vitalidade dos précondroblastos, declinam com a idade, desta forma diminuindo o potencial de adaptação da articulação em macacos com o passar da idade.

Em 1987, conduziu-se um estudo realizado em macacos (Macaca fascicularis), por WOODSIDE; METAXAS; ALTUNA ${ }^{209}$ para avaliar o remodelamento ocorrido no côndilo e, particularmente, na fossa glenóide em resposta ao avanço mandibular contínuo, reativado progressivamente de 1 a $2 \mathrm{~mm}$ a cada duas semanas. Adaptou-se o aparelho de Herbst, tipo esplinte metálico, em cinco macacos, enquanto que dois macacos serviram como controle, totalizando sete macacos (seis fêmeas e um macho), com 24 a 80 meses de vida. Após 12 semanas de experimento, os animais experimentais desenvolveram uma má oclusão de Classe III, o que não se observou nos animais controles. A inserção de implantes metálicos associada às telerradiografias mostraram que, com o avanço mandibular total de 7 a $10 \mathrm{~mm}$, a mandíbula apresentou-se deslocada anteriormente em relação à base craniana, os molares superiores distalizaram, os incisivos inferiores intruíram e vestibularizaram, e os molares inferiores mesializaram e suavemente erupcionaram. Não se constatou, no entanto, crescimento mandibular adicional. A avaliação histológica permitiu visualizar as alterações desencadeadas na articulação temporomandibular, que se concentraram mais precisamente na fossa glenóide, com uma remodelação anterior extensiva, sendo este o achado mais importante deste estudo. No entanto, nos animais mais jovens, verificou-se também uma proliferação dos tecidos condilares e conseqüente aumento do comprimento mandibular após o tratamento. Em geral, concluiu-se que as mudanças na articulação temporomandibular, seguidas à condição de protrusão mandibular contínua e progressiva, auxiliam na correção da relação maxilomandibular desproporcionada, posicionando a mandíbula para a anterior. 
No mesmo ano, McNAMARA JÚNIOR; BRYAN ${ }^{103}$ investigaram as alterações ocorridas na mandíbula, quanto à velocidade e direção de crescimento, com a protrusão funcional mandibular em macacos (Macaca mulatta) com 18 a 24 meses de vida no início do experimento, correspondentes ao início da dentadura mista em humanos. Doze animais serviram como animais controles, e 11, como animais experimentais em que foram submetidos a uma protrusão mandibular de 4 a $5 \mathrm{~mm}$. Radiografaram-se os animais ao início do experimento e 48, 96 e 144 semanas após a instalação dos aparelhos. A associação de implantes metálicos com a análise cefalométrica permitiu constatar que o crescimento mandibular em macacos pôde ser aumentado, com 6 a 7\% de aumento no comprimento mandibular em 144 semanas de experimento, já podendo ser constatada uma grande diferença estatística no primeiro ano de experimento. Quando se comparou o grupo controle com o experimental durante o primeiro ano de experimento, o maior aumento no côndilo procedeu-se ao longo da região posterior, enquanto que diferenças não significantes foram encontradas quanto à quantidade de crescimento no sentido vertical. Logo, não somente a velocidade como a direção de crescimento foram alteradas já nesse primeiro período experimental. Este estudo comprovou que adaptações significantes podem ocorrer na articulação temporomandibular em animais em fase de crescimento, com respostas mais pronunciadas nos estágios de dentadura mista, tornando-se menos evidentes com o envelhecimento dos animais. Adicionalmente, os resultados não suportaram a hipótese de que a mandíbula apresenta o seu comprimento pré-determinado geneticamente.

SESSLE; WOODSIDE; BOURQUE; GURZA; POWELL; VOUDOURIS; METAXAS; ALTUNA ${ }^{177}$, em 1990, estudaram os efeitos musculares adaptativos com o avanço postural da mandíbula em seis macacas (Macaca fascicularis) em fase de dentadura mista - entre 18 e 24 meses de idade. Utilizaram-se dois tipos de aparelhos ortopédicos funcionais, entre eles o de Herbst em duas macacas, com ativações periódicas a cada 10, 15 dias totalizando um total de 7,5 a $10 \mathrm{~mm}$ de protrusão anterior. Os resultados histológicos associados à adaptação dentária, esquelética e neuromuscular mostraram um aumento estatisticamente significante de nova formação óssea, a qual remodelou a fossa glenóide anteriormente nos animais experimentais comparados com dois animais controles e uma proliferação extensiva 
do tecido condilar nos animais que foram submetidos à protrusão mandibular. A atividade eletromiográfica postural apresentou-se diminuída de maneira significante para os músculos pterigóide lateral, masseter e digástrico, evidenciando claramente que a utilização de aparelhos funcionais em macacos está associada com diminuições significantes na atividade eletromiográfica dos músculos mastigatórios. Concluiu-se que o crescimento mandibular aumentado após a instalação dos aparelhos funcionais não decorreu da atividade postural aumentada da cabeça superior do músculo pterigóideo lateral ou outro músculo mastigatório estudado.

Em 2003, PETERSON JÚNIOR; McNAMARA JÚNIOR ${ }^{145}$ estudaram histologicamente as respostas teciduais sobre o côndilo mandibular, borda posterior do ramo da mandíbula e fossa glenóide, produzidas pelo avanço da mandíbula (média de 2,8mm) com o aparelho de Herbst tipo esplinte de acrílico, colado no arco superior e inferir. O grupo experimental consistiu de 20 jovens macacos (Macaca mulatta), com quatro macacos sacrificados após três semanas de experimento, seis macacos após seis semanas, seis macacos após 12 semanas e quatro macacos após 24 semanas, e o grupo controle de sete macacos. Os resultados indicaram adaptações estruturais na articulação temporomandibular após a colocação do aparelho. Entre essas adaptações, citam-se: proliferação aumentada da cartilagem condilar nas regiões posterior e póstero-superior, no período inicial de avanço mandibular; reabsorção óssea significante da superfície posterior da espinha pósglenoidal e deposição óssea significante na sua superfície anterior indicando um reposicionamento anterior da fossa glenóide; e, por fim, aposição óssea significante na borda posterior do ramo mandibular durante os primeiros períodos de experimento.

No mesmo ano, os autores McNAMARA JÚNIOR; PETERSON JÚNIOR; PANCHERZ $^{107}$ seguiram a mesma metodologia anterior, porém agora em 14 macacas adultas (Macaca mulatta) como grupo experimental e sete macacas como controle. O avanço mandibular médio foi de $3,3 \mathrm{~mm}$. Os resultados mostraram, nos animais experimentais, adaptações estruturais nas articulações temporomandibulares com um aumento da proliferação da cartilagem condilar, de modo progressivo, e espessamento do tecido articular, particularmente após 12 e 24 semanas da colocação do aparelho. Os autores argumentaram os achados baseados 
em estudos prévios, concordando com uma redução do potencial adaptativo da articulação temporomandibular com o avanço da idade nos animais. Contudo, mesmo com o potencial diminuído, alguma habilidade em se adaptar à função oclusal alterada persistiu.

Também no ano de 2003, RABIE; CHAYANUPATKUL; HÄGG ${ }^{153}$ objetivaram identificar o padrão de formação óssea na articulação temporomandibular em resposta ao avanço mandibular gradual comparado ao avanço de uma única vez com um aparelho funcional fixo, tipo Herbst. Selecionaramse 100 ratos para a colocação do aparelho com avanço único da mandíbula (3,5mm), 100 ratos para o avanço gradual (avanço inicial de $2 \mathrm{~mm}$ e, após 30 dias, mais $1,5 \mathrm{~mm})$ e 50 ratos como animais controles. Sacrificaram-se os ratos em períodos pré-determinados - 3,7, 14, 21, 30,33,37, 44, 51 e 60 dias e a quantificação de novo osso formado procedeu-se por métodos computadorizados. Mediante os resultados, observaram que, nos animais controles, a quantidade de novo osso declinou do terceiro ao último dia de observação. Nos animais com o avanço mandibular único, detectou-se novo osso na região posterior tanto do côndilo como da fossa glenóide, sendo a quantidade maior que no grupo controle, com níveis máximos nos dias 30 e 21 para côndilo e fossa respectivamente, seguido posteriormente por um declínio dos níveis - o mesmo alcançado durante o crescimento natural. No grupo com avanço gradual, a quantidade de novo osso formado foi significantemente maior que nos demais em decorrência da segunda ativação realizada, com manutenção do nível ósseo por todo período de observação. Concluiu-se que, do ponto de vista clínico, o avanço gradual produz mais efeitos esqueléticos que o avanço único e que esses efeitos foram mais expressivos na fossa glenóide (duas vezes mais) que no côndilo.

A interação entre duas Universidades renomadas mundialmente (Universidade de Nova York e Universidade de Toronto) contribuiu para a realização de um estudo científico de alto padrão em humanos e em animais envolvendo novos métodos tecnológicos de análise, com o objetivo de se conhecer mais a fundo as interações musculares e as alterações temporomandibulares com o tratamento ortopédico funcional fixo. O estudo compreendeu duas amostras. A primeira, formada por animais, constou de 15 macacos (Macaca fascicularis) com oito fêmeas na 
dentadura mista, seis fêmeas no início da dentadura permanente e um macho na dentadura permanente. Dividiram-nos em grupo experimental, com a utilização do aparelho de Herbst com cobertura oclusal e grupo controle. A segunda amostra, por sua vez, compreendeu 17 humanos, cinco do gênero feminino e 11 do masculino, no início da dentadura permanente, tratados com o mesmo tipo de aparelho por seis meses, e 24 humanos, combinados em idade e gênero, como controle. Estes últimos foram oriundos do arquivo Burlington Growth Centre, Universidade de Toronto. Publicou-se o estudo em duas seções, no ano de $2003^{196,197}$, com distintos focos de interesse, que serão relatados a seguir.

Na primeira seção, VOUDOURIS; WOODSIDE; ALTUNA; KUFTINEC; ANGELOPOULOS; BOURQUE ${ }^{197}$ preocuparam-se em descrever detalhadamente as técnicas utilizadas para o estudo, as quais são: a cefalometria, utilizada rotineiramente pelos ortodontistas; os eletrodos eletromiográficos, para monitorar a atividade muscular; cortes não calcificadas com coloração vital de tetraciclina intravenosa e microfluoroscopia para revelar a formação óssea; e a histomorfometria computadorizada para quantificar o novo osso formado. Verificaram histologicamente que a direção de crescimento da fossa glenóide mostrou-se para inferior e para posterior nos animais controles, confirmando achados radiográficos prévios. Contudo, nos animais experimentais, com a colocação do aparelho de Herbst, a direção de crescimento foi inversa, ou seja, para inferior e para a anterior, devido a uma restrição do crescimento natural da fossa, com uma formação óssea significante em torno de 1,2mm em 12 semanas nesta direção.

$\mathrm{Na}$ segunda seção, VOUDOURIS; WOODSIDE; ALTUNA; ANGELOPOULOS; BOURQUE; LACOUTURE ${ }^{196}$ discutiram principalmente os resultados encontrados com a realização da pesquisa. Com a ativação progressiva da mandíbula nos animais experimentais de 1,5 a $2 \mathrm{~mm}$ a cada 10 ou 15 dias, durante seis a 18 semanas de duração, alcançou-se uma sobrecorreção da relação molar de Classe I devido a vários fatores, sendo eles: o deslocamento mandibular em sentido anterior, o crescimento condilar aumentado (grande proliferação nas regiões pré-condroblásticas e condroblásticas), a restrição do crescimento maxilar, mudanças dentárias no arco superior em sentido posterior e, no arco inferior, em sentido anterior. Adicionalmente a esses achados, mudanças provenientes da 
remodelação da fossa glenóide (crescimento para inferior e para a anterior) contribuíram diretamente com a nova relação molar. Verificou-se que o crescimento mandibular aumentado é altamente influenciado pelo crescimento condilar (em direção posterior e superior), em macacos na dentadura mista, sendo idade dependente e que a formação de novo osso no côndilo e na fossa glenóide estava associada a uma atividade eletromiográfica postural diminuída dos músculos da mastigação e não a uma hiperatividade do músculo pterigóideo lateral. Este resultado, surpreendentemente, suporta a etiologia não muscular da modificação do crescimento condilar e da fossa glenóide.

\subsection{Tratamento Ortopédico Mecânico}

As resultantes de forças aplicadas sobre os dentes e transmitidas aos ossos subjacentes redirecionando o crescimento do complexo craniofacial, define a filosofia de tratamento ortopédico mecânico das más oclusões. Nestes casos, a melhora no relacionamento espacial maxilomandibular provém da aplicação planejada de dispositivos mecânicos, exemplificados pela utilização de elásticos, nas trações maxilares extrabucais, para a liberação de forças necessárias às alterações dento-esqueléticas ${ }^{9,49}$.

\subsubsection{Aparelho Extrabucal de Tração Occipital}

Inúmeros relatos científicos e clínicos, analisando os efeitos dentoesqueléticos e tegumentares de diferentes tipos de aparelho Extrabucal nas correções das más oclusões, são datados com entusiasmo desde o início do século passado, quando o professor Albin Oppenheim ${ }^{123}$ divulgou os benefícios da sua aplicação, caracterizando-o como o melhor método ortodôntico na movimentação dentária, após um período de estagnização em decorrência da preferência pelos elásticos intermaxilares nas clínicas ortodônticas ${ }^{119}$. A inesgotável busca por comprovações científicas da sua mecânica de ação, bem como a rotineira aplicação clínica desta respeitosa modalidade terapêutica, a mantém, desde então, de modo 
imbatível entre os profissionais da área, como opção de tratamento ou mesmo como substituto às terapias não bem sucedidas.

Em 1948, EPSTEIN ${ }^{47}$, revisando a literatura divulgada por ortodontistas bem sucedidos da época, propôs investigar as alterações dento-esqueléticas induzidas em más oclusões de Classe II, divisão 1 com a utilização de forças extrabucais. A amostra compôs-se de 12 pacientes não tratados ortodonticamente entre cinco e 18 anos de idade e 12 pacientes, entre seis e 10 anos de idade no início da terapia, tratados apenas com o aparelho Extrabucal de tração média por 13 meses aproximadamente. Os resultados mostraram um movimento no sentido ântero-inferior dos molares superiores, em condição normal de crescimento seguindo a tendência natural do comportamento maxilar, enquanto que os molares que receberam a tração foram movimentados em sentido posterior em relação à maxila. Não se evidenciou um movimento no sentido anterior dos molares inferiores nos casos tratados. Concluiu-se que a mecânica abordada foi efetiva na correção molar das Classes II, com restrição do movimento natural dos primeiros molares superiores e que o sucesso do tratamento depende fielmente das mudanças individuais do crescimento e desenvolvimento e da cooperação do paciente.

POULTON ${ }^{151}$, em 1964, comparou cefalometricamente os efeitos dentoesqueléticos de pacientes com más oclusões de Classe II, divisão 1 , que foram tratados por três anos com o aparelho Extrabucal de tração occipital. Vinte e duas telerradiografias foram selecionadas para o grupo experimental, com a idade inicial média de 10,33 anos, comparadas com um grupo controle, sem ter sido submetido à intervenção ortodôntica. Baseado nos dados obtidos, constatou-se que a média de distalização dos molares superiores em um ano de tratamento foi de $2 \mathrm{~mm}$ e em dois anos, 0,8mm. Entretanto, em três anos de terapia, evidenciou-se em média uma mesialização de $0,9 \mathrm{~mm}$. Por outro lado, no grupo controle, a mesialização foi diagnosticada por todo o período de observação nos molares e incisivos superiores, deteriorando a relação de Classe II existente. O autor conclui que os molares e os incisivos superiores, em período ativo de tratamento, continuam a mesializar acompanhando o crescimento natural da maxila, porém de uma forma menos veloz quando comparada a períodos semelhantes sem intervenção mecanoterápica. 
Adicionalmente, o autor destacou a importância em se direcionar corretamente a aplicação da força extrabucal para o controle dos movimentos dentários.

Em 1966, BAALACK; POULSEN ${ }^{5}$ examinaram os benefícios da tração occipital, utilizada por um ano com uma força média de 500 gramas por lado, em nove meninos e 20 meninas, com a idade inicial média de 11 anos, apresentando a má oclusão de Classe II. Para adquirirem uma opinião quanto à migração mesial dos primeiros molares superiores em casos não tratados ortodonticamente, utilizaram-se de 22 pacientes apresentando a mesma má oclusão. Mediante as análises em modelos ortodônticos de estudo, constataram que o tratamento por meio da tração occipital contribuiu para uma melhora no relacionamento molar do que propriamente para uma distalização efetiva dos molares superiores. Os autores atribuem esse achado como conseqüência da mesialização inibida desses dentes em combinação com o crescimento da mandíbula em sentido anterior. Observou-se também uma redução suave na sobressaliência, atribuindo-a ao crescimento da mandíbula em direção anterior em conexão com a obtenção de uma oclusão mais estável. Relacionaram o prognóstico da distalização dos primeiros molares superiores a um início de tratamento anterior à erupção dos segundos molares superiores, à condição de espaço adequada no arco inferior e ao espírito de cooperação durante o tratamento.

Com o objetivo principal de determinar os efeitos do tratamento com o aparelho Extrabucal de tração occipital, WATSON ${ }^{198}$, em 1972, analisou 14 pacientes, sendo 12 do gênero feminino e dois do masculino, entre as idades de seis a 10 anos, com tomadas radiográficas adquiridas em três diferentes períodos, durante o tratamento, que se procedeu por dois anos. Aplicou-se uma magnitude média de força de 600 gramas por lado e tentou-se coincidir a linha de ação com o centro de resistência do molar. Os resultados a seguir foram obtidos em média por ano: o eixo facial foi aberto em $0,03^{\circ}$, evidenciando um bom controle sobre a direção de crescimento; a convexidade facial reduzida em 1,5mm (medida linear nesta análise); a relação molar e a sobressaliência foram reduzidas em $3 \mathrm{~mm}$, com movimento de corpo do molar e controle da inclinação dos incisivos; a altura facial ântero-inferior diminuiu em $0,72^{\circ}$ (medida angular nesta análise), mesmo com o palato sendo inclinado inferiormente na região anterior; a posição do molar superior 
foi reduzida em 2,22mm; os molares superiores foram intruídos, com inclinação superior do plano oclusal na região posterior; os ângulos S.N.A e S.N.B foram diminuídos em $1,94^{\circ}$ e em $0,28^{\circ}$, respectivamente; e o ângulo SN.GoGn diminuiu em $0,44^{\circ}$. O autor citou inúmeras vantagens em se tratar precocemente os pacientes com esta mecanoterapia e enfatizou ser o crescimento útil mas não essencial durante o seu tratamento ativo.

Almejando a um embasamento histológico e cefalométrico dos efeitos produzidos pela utilização do aparelho Extrabucal de tração occipital, ELDER; TUENGE ${ }^{45}$, em 1974, utilizaram seis macacos (Macaca mulatta), na fase de dentadura mista, sendo dois desses designados como macacos controles, sem nenhuma intervenção ortodôntica. Aplicou-se uma força de 700 gramas por lado, direcionada a $40^{\circ}$ do plano oclusal, em esplintes metálicos conectados ao arco superior, com verificações periódicas para a manutenção da magnitude e direção da força aplicada. Após um período experimental de 71 dias e de observação de 63 dias, clinicamente se evidenciou uma mudança notável no perfil de Classe I para a Classe III nos animais submetidos à mecanoterapia. Com a colocação de implantes metálicos, associada à sobreposição de traçados cefalométricos, constataram-se, nos animais tratados, as seguintes alterações: um reposicionamento da maxila e elementos dentários para superior e posterior, com o ponto A deslocado para posterior; uma rotação em sentido anti-horário da mandíbula, com diminuição do ângulo do plano mandibular; e um alongamento da cabeça do côndilo. Esses resultados cefalométricos foram praticamente o inverso dos resultados encontrados no grupo controle. A sutura zigomaticotemporal foi extremamente influenciada com a terapia, sendo reabsorvida 17 vezes a mais que em condição normal e a sutura zigomaticomaxilar foi alterada de uma condição de deposição para uma condição de reabsorção. Não se observaram mudanças nas suturas zigomaticofrontais, ou suturas frontomaxilares. As condições histológicas confirmaram as respostas suturais e a movimentação para distal e vestibular dos dentes superiores. Este estudo provou que, com a aplicação de forças extrabucais, não somente os dentes são afetados, mas toda a maxila e os ossos do terço médio da face, mediado por reabsorções nas articulações da maxila. Foi evidente, com a aplicação do aparelho Extrabucal, a inibição do crescimento maxilar normal e o seu deslocamento em sentido posterior e superior, e que o movimento distal encontrado nos molares inferiores foi em 
decorrência da transmissão das forças distais oriundas do arco superior para o arco inferior.

Com a intenção de avaliar em animais os efeitos do emprego da tração extrabucal sobre o padrão de crescimento esquelético facial superior, que se direciona para a inferior e para a anterior em situações normais, em 1975, MELDRUM ${ }^{109}$ estudou histológica e cefalometricamente quatro macacos (Macaca mulatta), submetidos à mecânica extrabucal de tração occipital. Designaram-se três animais como grupo experimental e um animal, como controle, com uma idade aproximada à humana entre seis e sete anos. Para a aplicação da força sobre o arco superior, utilizou-se um esplinte metálico cimentado sobre os dentes superiores, em que se empregou uma magnitude de força, por lado, de 300 gramas, durante um período de 81 a 89 dias, com a linha de ação da força em média de $40^{\circ} \mathrm{com}$ o plano oclusal. Os dados cefalométricos (com o auxílio da implantação de implantes) e os histológicos sugeriram que o aparelho Extrabucal desacelerou, ou mesmo reverteu, o padrão normal de deslocamento facial superior, atribuindo a essa terapia a possibilidade de prevenir o movimento para frente e para baixo da maxila em período de crescimento. Quase todos os implantes faciais nos animais foram deslocados para cima e para trás relativos à base craniana. As maiores alterações ortopédicas foram vistas no osso maxilar, comparado com o frontal, temporal e o zigomático, já que os dentes em que a força era aplicada estão contidos nesse osso. O plano palatino foi deslocado superiormente e rotacionado em sentido anti-horário em todos os componentes experimentais, o que surpreendeu o autor, acompanhando o movimento dos esplintes em mesmo sentido. Atribuiu-se este movimento do esplinte ao movimento dentário e à remodelação sutural e óssea do complexo esquelético facial superior. Não se constatou movimento de corpo dos dentes superiores.

CHACONAS; CAPUTO; DAVIS ${ }^{33}$, em 1976, objetivaram determinar a natureza das forças transmitidas às estruturas craniofaciais pelas trações ortopédicas cervical e occipital, já que na época havia um conflito de idéias quanto à sua real implicação. Utilizaram-se para esse experimento, modelos tridimensionais reproduzidos de crânios humanos com materiais birrefringentes para simular osso, dentes e ligamento periodontal. Forças de 1.250 gramas em cada lado foram transmitidas através de um aparelho e observações foto-elásticas do estresse 
desenvolvido nos modelos eram checados. Os dados obtidos mostraram que algumas áreas anatômicas sofreram ação por ambas as trações, como o processo pterigóide do osso esfenóide, o arco zigomático, a junção do osso maxilar com o lacrimal e com o processo orbitário do etmóide e ao redor dos molares superiores. Algumas estruturas, por sua vez, sofreram ação dependendo da tração utilizada. Por exemplo, a cervical estimulou reações no processo frontal da maxila, na sutura zigomaticofrontal e na junção dos ossos palatinos e a occipital, na junção anterior da maxila (região inferior à espinha nasal anterior - ao redor do ponto cefalométrico A). Os resultados mostraram que ambas as ativações produziram forças ao redor dos dentes e à distância nas estruturas craniofaciais, sendo este último o achado de maior importância extraído desse estudo. De particular interesse clínico, a tração cervical desencadeou inclinações extensas nos primeiros molares superiores. Como a intensidade das forças aplicadas foi maior quando da aplicação da tração cervical e por ela também ter repercutido em mais áreas, os autores concluem que as mudanças ortopédicas com essa tração é maior que com a occipital.

BROWN ${ }^{27}$, em 1978, propôs estudar a aplicação intermitente (de 12 a 16 horas por dia) da força extrabucal suave (entre 200 a 600 gramas por lado) em pacientes que se encontravam na fase de dentadura mista tardia ou no início da permanente. A amostra compreendeu 11 meninas e seis meninos utilizando a tração occipital (força direcionada para cima e para trás), com uma idade inicial média de 13,7 anos e 13 meninas e sete meninos utilizando a tração cervical (força direcionada para baixo e para trás), com uma idade inicial média de 13,1 anos. Selecionou-se também um grupo controle sem qualquer intervenção mecanoterápica, porém em menor número que o experimental e com uma idade inicial média de 11,9 anos. Mediante os resultados cefalométricos após um ano de tratamento, ao se compararem os grupos experimentais com o grupo controle, verificou-se que a tração cervical promoveu uma redução dos ângulos S.N.A e A.N.B, uma inclinação da maxila e da mandíbula para baixo e para trás, extrusão dos molares superiores e uma inclinação no sentido horário do plano palatino. O aumento da altura facial anterior e da angulação do plano mandibular nos pacientes tratados foram provavelmente decorrentes da extrusão dos molares superiores. A tração occipital, por outro lado, favoreceu apenas extrusão dos molares inferiores, porém não se constatou um aumento na altura facial ântero-inferior. Concluiu-se que é de extrema 
importância a seleção correta dos aparelhos extrabucais, pois quando o crescimento no sentido vertical é julgado ser adequado ou excessivo, visto pelas mensurações da altura facial anterior, do plano mandibular ou da erupção vertical dos molares superiores, a tração occipital é a terapia de escolha. Já em casos com características opostas, aplica-se a tração cervical encorajando o desenvolvimento craniofacial no sentido vertical.

Também no ano de 1978, BAUMRIND; MOLTHEN; WEST; MILLER ${ }^{17}$ investigaram a ação sobre a maxila de cinco tipos de modalidades terapêuticas, incluindo forças ortopédicas mecânicas e funcionais, com o objetivo de se avaliar as alterações induzidas no plano mandibular. Duzentos e quarenta e nove pacientes com más oclusões de Classe II compuseram a amostra, sendo divididos de acordo com o aparelho utilizado, num tempo médio de tratamento de 24 meses. Em específico, o grupo experimental tratado com o aparelho Extrabucal de tração occipital compôs-se de 53 pacientes, sendo 19 do gênero masculino e 34 do feminino, com a idade inicial média de 8,85 anos e o grupo controle, para comparação com todos os grupos experimentais, compôs-se de 54 pacientes, com a idade inicial média de 8,44 anos. De acordo com os resultados alcançados a curto prazo, obteve-se a correção da relação molar com a utilização de todos os aparelhos, enquanto que no grupo controle essa relação permaneceu inalterada. Verificou-se que o plano mandibular no grupo controle mostrou uma tendência em diminuir durante o período de observação, enquanto que nos grupos experimentais, mesmo com um suave aumento, não se alterou de modo estatisticamente significante. Os autores asseguraram esse comportamento devido à seriedade com que os profissionais trataram esses pacientes, impedindo com que a mandíbula rotacionasse de modo exagerado.

Os mesmos autores BAUMRIND; MOLTHEN; WEST; MILLER ${ }^{18}$ deram prosseguimento à interpretação dos resultados obtidos, na pesquisa anterior, com o intento de associar alguns fatores que possam contribuir com o aumento do ângulo do plano mandibular em casos tratados. Constataram que, quanto mais deslocamento houver do molar para a distal, maior a tendência em se abrir o ângulo do plano mandibular. Este achado implica que qualquer esforço para corrigir a relação molar, em bases não extracionistas, pela distalização dos molares superiores 
ou pela restrição de sua mesialização normal com o crescimento, criará condições para a abertura do plano mandibular. Verificaram também que, quanto mais os primeiros molares superiores extruírem, maior a tendência em se abrir este ângulo.

Em 1979, BRANDT; SHAPIRO; $\mathrm{KOKICH}^{24}$ propuseram delinear as possibilidades e limitações da aplicação da força extrabucal às articulações craniofaciais de animais adultos. A amostra consistiu de dois macacos (Macaca fascicularis) e de duas macacas em idade adulta entre seis e sete anos. Aplicaramse implantes metálicos para o auxílio na interpretação cefalométrica e implantes occipitais para o auxílio na ancoragem. A direção da tração, aplicada em esplintes maxilares, foi de $30^{\circ}$ aproximadamente com o plano oclusal e a força exercida foi de 450 gramas por lado. A fase experimental ativa durou de 84 a 205 dias, alcançando nos animais experimentais trespasses horizontais negativos ao redor de $9 \mathrm{~mm}$. Os resultados revelaram que todos os animais apresentaram um deslocamento superior e posterior da maxila, resultando em mudanças da relação dentária normal de Classe I para Classe III. Os planos palatino e oclusal foram deslocados para posterior e para superior com uma suave rotação em sentido anti-horário. A mandíbula moveu-se posteriormente em vários graus em todos os animais, com suave diminuição do ângulo do plano mandibular e com diminuições significantes da altura vertical anterior. Os dentes superiores foram lingualizados de modo significante e os primeiros molares superiores inclinados, em relação ao plano palatino, em $14^{\circ}$. As sobreposições dos traçados demonstraram que a interação das relações dentárias com as esqueléticas, durante a fase ativa, foi em torno de 2/1. Como estabelecido que o centro de rotação do complexo dentofacial localizou-se na região superior da maxila e ossos zigomáticos, o complexo facial foi trasladado superiormente, com grandes mudanças remodeladoras observadas nas suturas zigomaticomaxilar e zigomaticotemporal, e menores mudanças na sutura zigomaticofrontal, como constatado histologicamente. O estudo confirmou que a força extrabucal direcionada posteriormente sobre a maxila, em animais adultos, resultou em alterações dramáticas na morfologia das suturas e no relacionamento espacial da maxila.

Com a mesma metodologia aplicada nas pesquisas anteriores, em 1981, BAUMRIND; KORN; MOLTHEN; WEST ${ }^{16}$, e BAUMRIND; KORN ${ }^{14}$, continuaram a estudar os efeitos sobre o terço inferior da face, a partir da aplicação de forças de 
retração na maxila. Verificaram um aumento expressivo da medida Co-Pog principalmente nos pacientes tratados com aparelhos ortopédicos funcionais e uma redução na velocidade de incremento da altura facial ântero-inferior no grupo experimental com a utilização da tração occipital, comparado ao grupo controle, enquanto que a velocidade de incremento da altura facial anterior total permaneceu inalterada. Em geral, os autores aconselharam a não-utilização da tração cervical em pacientes com altura facial ântero-inferior aumentada.

Com o intento de identificar e quantificar os componentes ortodônticos e ortopédicos do deslocamento dos primeiros molares superiores e da ENA (espinha nasal anterior) com a utilização de diferentes sistemas de tratamento, BAUMRIND; KORN; ISAACSON; WEST; MOLTHEN ${ }^{15}$, em 1983, selecionaram 238 pacientes, na dentadura mista, com más oclusões de Classe II. Cinqüenta pacientes compuseram o grupo controle, enquanto que os demais, 188 pacientes, compuseram os grupos experimentais, divididos de acordo com a terapia aplicada (aparelho Extrabucal de tração cervical com a aplicação de forças leves; aparelho Extrabucal de tração occipital com a aplicação de forças pesadas; e o aparelho Ativador com forças bem leves). Os resultados demonstraram que, no grupo controle, o plano palatino permaneceu inalterado, os molares superiores mesializaram e extruíram aproximadamente $3 \mathrm{~mm}$ e as coroas inclinaram para mesial, em torno de $1 \mathrm{~mm}$ a mais que as raízes durante o processo de erupção. Com a tração cervical, o deslocamento anterior da ENA foi expressivamente reduzido ao se comparar com o grupo controle. Analisando a efetividade da tração occipital, os autores verificaram que os molares superiores foram deslocados para superior e para posterior aproximadamente $2,5 \mathrm{~mm}$ e suas coroas foram inclinadas para distal $2,5^{\circ}$ em relação às suas raízes, afirmando ser a terapia de maiores mudanças na região desses dentes e em menor tempo de tratamento. Os efeitos com o aparelho Ativador foram menores em magnitude comparados aos outros aparelhos. De maneira geral, os autores constataram que a utilização de forças para a retração da maxila produz efeitos substanciais nesse osso, tanto de natureza ortodôntica como de natureza ortopédica. Para surpresa dos autores, verificaram que com a aplicação de forças pesadas (tração occipital), as alterações de natureza ortodôntica foram mais evidentes que as alterações ortopédicas, e que com a tração cervical, o efeito inverso se manifestou, mostrando um efeito ortodôntico menor que o ortopédico. Com o Ativador, em que se empregou 
a menor força, os efeitos foram divididos igualmente. Os autores concluíram que forças mais pesadas tendem a deslocar os dentes enquanto que forças mais leves tendem a deslocar a matriz óssea como todo.

No mesmo ano, RIGHELLIS ${ }^{160}$ avaliou os efeitos dento-esqueléticos em pacientes com más oclusões de Classe II, divisão 1, na fase de dentadura mista, promovidos por quatro tipos de parelhos ortopédicos: o Ativador de Andresen, o Regulador funcional de Fränkel, o Extrabucal de tração occipital e o de tração cervical. Ao se compararem os resultados cefalométricos obtidos dos grupos experimentais com os dados provenientes de um grupo controle, verificaram que todas as modalidades terapêuticas corrigiram a relação molar existente de Classe II e que se diferenciaram quanto aos efeitos no complexo craniofacial. O Aparelho Extrabucal de tração occipital desencadeou o maior efeito retrusivo na posição do ponto $A$, no sentido ântero-posterior, em relação aos demais aparelhos. Quanto à altura facial ântero-inferior, estabeleceu-se que as mudanças nessa dimensão, decorrentes dos vários métodos de tratamento, são altamente variáveis para uma predição confiável, necessitando de uma avaliação clínica regular para o monitoramento de qualquer alteração indesejável. A variabilidade interindividual foi o aspecto mais importante nos achados deste estudo, devendo haver, por parte dos ortodontistas, um conhecimento imprescindível do crescimento e desenvolvimento normal dos maxilares.

KRAGT; DUTERLOO; ALGRA ${ }^{90}$, em 1986, avaliaram, em holografias a laser, oito crânios humanos macerados, com uma média de idade aproximada em 9,5 anos, submetidos a um sistema de tração extrabucal occipital. Os efeitos observados por esse estudo evidenciaram deslocamentos dos componentes craniofaciais, com a maxila, predominantemente, deslocada em direção posterior e pouco ou nenhum deslocamento desse osso em direção superior vertical. Em conclusão, demonstrou-se que crânios humanos macerados podem servir como modelos sob cargas em experimentos, e que nem sempre o deslocamento da maxila e outros ossos se concretizam na mesma direção das forças aplicadas, sendo influenciado pela morfologia craniofacial e relacionamento intersutural. 
Em 1992, FIROUZ; ZERNIK; NANDA ${ }^{49}$ propuseram investigar as mudanças dentárias e esqueléticas produzidas pelo aparelho Extrabucal de tração occipital tipo Interlandi, utilizando forças de baixa magnitude (500 gramas por lado), na correção das más oclusões de Classe II. Selecionaram-se 24 pacientes com as idades esqueléticas variando entre 9,5 e 12,5 anos, com o espaço interlabial de 2mm no mínimo e com uma altura facial ântero-inferior aumentada. Entretanto, apenas 12 pacientes receberam a mecanoterapia, tendo os demais como grupo controle. Direcionou-se a força, liberada pelo elástico (trocado diariamente), para cima e para trás passando aproximadamente pelo centro de resistência dos primeiros molares superiores, com uma angulação, relativa ao plano oclusal, ao redor de $20^{\circ}$. Adicionalmente à força extrabucal, empregou-se uma barra transpalatina com a função de prevenir rotação dentária, simetria de movimentação entre os lados e manter a distância intermolar. As radiografias cefalométricas de norma lateral foram tomadas ao início e seis meses após o tratamento. Perante os resultados cefalométricos, observou-se que, em seis meses de tratamento com um uso diário do aparelho de 12 horas em média por dia, as mudanças mais significantes foram nos primeiros molares superiores. Esses dentes foram deslocados para a distal $(X=$ $2,56 \mathrm{~mm})$ e intruídos $(X=0,54 \mathrm{~mm}$ ) enquanto que, no grupo controle, eles mesializaram $(X=0,23 \mathrm{~mm})$ e erupcionaram $(X=0,42 \mathrm{~mm})$. Logo, os molares superiores foram deslocados de acordo com a direção da força extrabucal aplicada e o movimento distal foi de translação contribuindo para a correção da relação molar de Classe II. Mudanças esqueléticas significantes também foram observadas na base apical superior, ou seja, o aparelho não só restringiu ou redirecionou o crescimento ântero-posterior da maxila como exerceu um efeito ortopédico movimentando-a distalmente. Concluiu-se neste estudo que a utilização da força extrabucal, de modo intermitente, pode também corrigir de maneira eficaz a relação molar de Classe II em um período curto de tempo.

Nesse mesmo ano, BURKE; JACOBSON ${ }^{28}$ estudaram as alterações esqueléticas no sentido vertical de pacientes com más oclusões de Classe II, divisão 1, que apresentavam inicialmente o ângulo do plano mandibular aumentado, tratados com o aparelho Extrabucal de tração cervical e com o aparelho Extrabucal de tração occipital. Selecionaram-se 32 pacientes para comporem a amostra de tração occipital, com a força direcionada em 10 a $12^{\circ}$ em relação ao plano oclusal e 21 
pacientes para compor a amostra de tração cervical, com a força direcionada paralela ao plano oclusal. Todos os pacientes se encontravam em fase de crescimento e três medidas foram estabelecidas para avaliar o comportamento do plano mandibular (SN.GoGn; SN.GolnMe; SN.PM). Um dos mais importantes achados cefalométricos deste estudo foi a ausência de grandes diferenças quanto às alterações no ângulo do plano mandibular decorrentes dos dois tipos de aplicação de força. Confirmou-se a extrusão dos molares superiores quando da utilização da tração cervical, porém não se verificou alteração no sentido vertical da face inferior. Os molares inferiores não foram alterados por ambas modalidades terapêuticas, evidenciando que o tipo de tração e o desenvolvimento vertical dos molares superiores parecem não interferir no desenvolvimento dento-alveolar inferior. Ocorreu uma diminuição significante do ângulo do plano oclusal nos pacientes tratados com a tração cervical, já que um adicional desenvolvimento dento-alveolar posterior vertical foi efetuado (o plano oclusal tende a inclinar para a inferior na região posterior). A tração occipital, por outro lado, inibiu este desenvolvimento dento-alveolar posterior vertical. No grupo tratado com a tração occipital, nenhuma correlação foi encontrada entre a medida do ângulo do plano mandibular e alterações na altura facial ânteroinferior ou na altura facial total. Em outras palavras, a altura facial ântero-inferior aumentada foi encontrada em casos onde o plano mandibular aumentou e em casos onde diminuiu. Em casos tratados com a tração cervical, por outro lado, alterações no ângulo do plano mandibular mostraram-se fortemente correlacionadas com a altura facial anterior total e com a ântero-inferior. Em ambos os grupos, principalmente com a tração occipital, as alterações na altura do molar superior (므$\mathrm{SN}, \underline{6}-\mathrm{PP}$ ) foram fortemente correlacionados com alterações nas variáveis da altura facial anterior. Já, nenhuma correlação significante foi encontrada entre as alterações na altura molar superior e alterações em qualquer das variáveis do ângulo do plano mandibular. Os autores acreditaram que com a inibição do desenvolvimento vertical dento-alveolar superior pela tração occipital, o desenvolvimento vertical dentoalveolar inferior seria encorajado na maioria dos casos, explicando a forte correlação entre a altura molar inferior e as variáveis da altura facial posterior. Os autores sugeriram uma certa precaução ao interpretar os resultados desse estudo devido à falta de controle de diversas variáveis, como duração do tratamento, cooperação dos pacientes... e que há grande variação individual quanto às respostas dentoesqueléticas aos tratamentos. 
YOSHIDA; JOST-BRINKMANN; YAMADA ${ }^{210}$, em 1995, analisaram em três estudantes, com idades entre 23 e 27 anos, a influência das diferentes direções de tração do aparelho Extrabucal sobre os primeiros molares superiores. Observaram que, com a utilização da tração occipital, as raízes dos primeiros molares superiores sofreram uma inclinação para distal, em decorrência da aplicação de força acima do centro de resistência. Um outro resultado, de grande importância, foi a vestibularização das coroas em conseqüência da aplicação de forças intrusivas, inerentes à tração occipital. Os autores alegaram ser a linha de ação da força uma importante consideração no controle dos efeitos de inclinação e que a posição do centro de resistência e outros fatores variam entre os indivíduos. Além destas afirmações, aconselharam os ortodontistas a verificarem e a ajustarem, regularmente, os aparelhos Extrabucais durante todo o tratamento no afã de se constatar alguma característica indesejável que possa interferir nos movimentos dentários durante a mecanoterapia.

Em 1998, GHAFARI; SHOFER; JACOBSSON-HUNT; MARKOWITZ; LASTER $^{53}$ propuseram avaliar os efeitos oclusais e cefalométricos de duas modalidades de tratamento da má oclusão de Classe II, bem como estabelecer o melhor período para a intervenção. Sessenta e três pacientes foram selecionados, seguindo alguns pré-requisitos como: discrepância maxilomandibular de, no mínimo, $4,5^{\circ}$ e idades esqueléticas variando de 5,7 a 13,7 anos. Dividiram-se os participantes em dois grupos: o primeiro composto por meninas e meninos com menos de $10 \mathrm{e}$ 10,5 anos respectivamente e o segundo grupo composto também por meninas e meninos, porém com mais de 10 e 10,5 anos, respectivamente. Os aparelhos de escolha foram o Regulador Funcional de Fränkel tipo II (16 horas por dia) e o aparelho Extrabucal de tração occipital (14 horas por dia), com a força passando, nesse último, pelo centro de resistência dos molares superiores. Os resultados mostraram que ambas as terapias foram efetivas no tratamento da má oclusão de Classe II, divisão 1, porém com respostas dentárias e esqueléticas diferenciadas. $\mathrm{O}$ alvo principal da mecânica extrabucal deu-se sobre a maxila (efeito ortopédico significante redução da medida S.N.A levando è redução do ângulo A.N.B; efeito ortodôntico - distalização dos molares superiores e vestibularização dos incisivos superiores), enquanto que a mecânica ortopédica funcional ocorreu-se sobre ambos 
os maxilares (restrição do crescimento maxilar e posicionamento mais anterior da mandíbula), porém com respostas mais expressivas nos dentes anteriores (lingualização dos incisivos superiores e vestibularização dos inferiores contribuindo para a grande correção da sobressaliência). O efeito no comprimento mandibular, por sua vez, foi similar ao se comparar as modalidades terapêuticas. Os autores concluíram que ambas as épocas de instalação dos aparelhos foram eficientes, priorizando o final do período da dentadura mista por reduzir o tempo total de tratamento e incentivaram a realização de estudos mais específicos quanto à influência das características individuais na época do tratamento, bem como na resposta à mecânica empregada.

HENRIQUES; FREITAS; HAYASAKI ${ }^{74}$, em 1999, revisando a literatura pertinente aos tratamentos ortodônticos com ancoragens extrabucais, reuniram, de modo eficaz, os principais efeitos dento-esqueléticos com o aparelho Extrabucal de tração occipital. Resumiram-se os efeitos ortodônticos em: distalização dos molares superiores, para a obtenção da relação molar normal; controle de uma possível extrusão dos molares superiores ou, em alguns casos, a possibilidade de intruí-los; tendência de inclinação das raízes para a distal e baixo risco de impacção dos segundos molares superiores permanentes. Já os efeitos ortopédicos em: restrição do crescimento maxilar no sentido ântero-posterior, identificada por uma diminuição significativa do ângulo S.N.A; melhor relacionamento entre as bases ósseas, visto pelo ângulo A.N.B; o mento adquire, em geral, uma posição mais anterior quando comparado à tração cervical; a altura facial ântero-inferior, em alguns estudos, chegou a diminuir ao final do tratamento e, em outros, houve pequeno aumento, quando a tendência era aumentar acentuadamente, principalmente em pacientes com a AFAl aumentada ou em pacientes com tendência de crescimento vertical; e com o controle do desenvolvimento vertical da maxila, a tendência de rotação horária da mandíbula diminui, auxiliando na melhora do perfil facial do paciente e no relacionamento dos molares.

Em 2001, BILLIET; PAUW; DERMAUT ${ }^{19}$ estudaram os efeitos no complexo nasomaxilar por meio de holograma, em um crânio humano macerado, pela a aplicação de forças em diferentes direções, simulando as trações baixa e média-alta. As respostas adquiridas mostraram que a região do centro de resistência 
da maxila situou-se abaixo do processo zigomático do complexo maxilar, pois quando o vetor de força era aplicado por esta região, o movimento de translação puro da maxila era induzido. Conseqüentemente, forças aplicadas acima desse centro e/ou abaixo, rotações no sentido anti-horário da maxila e no sentido horário eram visualizadas respectivamente.

\subsection{Comparação entre os dois Aparelhos}

Do arcabouço literário, não se extraem trabalhos que embasam cientificamente uma similaridade entre os aparelhos previamente discorridos quanto aos seus efeitos no complexo craniofacial, especificamente sobre a maxila e sim trabalhos que assimilam teoricamente os seus resultados. É dito incessantemente que a ação mecânica do aparelho de Herbst, produzindo uma força direcionada para superior e para posterior no complexo maxilar, seja equivalente à ação mecânica do aparelho Extrabucal de tração occipital ${ }^{96,127,129,134,138}$. A distalização e intrusão dos molares superiores, a inclinação do plano oclusal e a rotação do plano palatino no sentido horário são exemplos de comparação não fundamentada entre os dois aparelhos $^{130,134}$.

O frágil embasamento científico, por conseguinte, provocou 0 aparecimento de críticas, contribuindo para a elaboração desta atual pesquisa, que avaliará as alterações craniofaciais, no tratamento de más oclusões de Classe II, resultantes dessas duas modalidades terapêuticas. 
3- PROPOSIÇÃO 


\section{PROPOSIÇÃO}

Em função dos fatores exibidos anteriormente, o presente estudo tem o fim precípuo de analisar cefalometricamente, em telerradiografias, as alterações dento-esqueléticas a curto prazo decorrentes do tratamento exclusivo com o aparelho de Herbst e do tratamento exclusivo com o aparelho Extrabucal de tração occipital em pacientes com más oclusões de Classe II, divisão 1, utilizando, como referência, grupos controles, sem qualquer intervenção ortodôntica ou ortopédica.

Os tópicos a serem verificados, com relação às alterações craniofaciais, serão divididos de acordo com os componentes específicos, para as duas modalidades terapêuticas:

$>$ componente maxilar

componente mandibular

relação maxilomandibular

$>$ componente vertical

$>$ componente dento-alveolar superior

componente dento-alveolar inferior

relação interdentária

componente tegumentar 
4- MATERIAL E MÉTODOS 


\subsection{Material}

Dividiu-se a amostra deste estudo em quatro grupos, sendo dois experimentais e dois controles.

\subsubsection{Grupos Experimentais}

Todos os pacientes que compõem os grupos experimentais são leucodermas, brasileiros, originários do acervo e da clínica de pós-graduação da Disciplina de Ortodontia da Faculdade de Odontologia de Bauru, da Universidade de São Paulo.

- Grupo 1, constituído por 25 pacientes submetidos ao tratamento ortopédico funcional, utilizando o aparelho de Herbst com cantiléver exclusivamente, sendo 15 do gênero masculino e 10 do feminino. Todos os pacientes apresentavam, no início do tratamento, más oclusões de Classe II, divisão 1 de Angle, com a idade média de 12,01 anos. Alcançou-se a chave molar ideal, ou mesmo uma sobrecorreção tendendo a uma relação molar de Classe III, em um período médio real de tratamento de um ano, contudo com um período médio de obtenção das telerradiografias de um ano e dez meses, com a idade média final de 13,80 anos. Classificaram-se, de modo geral, os pacientes como cooperadores.

Os pré-requisitos clínicos na seleção dos pacientes que foram submetidos ao tratamento com o aparelho de Herbst:

1 más oclusões de Classe II, divisão 1, bilateral;

2 trespasse horizontal acentuado;

3 perfil facial convexo;

4 final da dentadura mista ou início da dentadura permanente;

5 melhora do perfil ao avançar clinicamente a mandíbula;

6 boa saúde bucal. 
É de fundamental importância salientar que a média das idades iniciais e finais e o tempo médio de tratamento ou de observação de todos os grupos deste estudo basearam-se nas datas fornecidas pelas documentações ortodônticas.

- Grupo 2, constituído por 25 pacientes submetidos ao tratamento ortopédico mecânico, utilizando o aparelho Extrabucal de tração occipital exclusivamente, sendo 10 do gênero masculino e 15 do feminino. Todos os pacientes apresentavam, no início do tratamento, más oclusões de Classe II, divisão 1 de Angle com a idade média de 10,28 anos. Alcançou-se a chave molar ideal em um período médio de tratamento de um ano e sete meses, com a idade média final de 11,82 anos. Classificaram-se, de modo geral, os pacientes como cooperadores.

Os pré-requisitos clínicos na seleção dos pacientes que foram submetidos ao tratamento com o aparelho Extrabucal de tração occipital:

1 más oclusões de Classe II, divisão 1, bilateral;

2 trespasse horizontal acentuado;

3 perfil facial convexo;

4 dentadura mista;

5 possibilidade de cooperação durante o tratamento;

6 boa saúde bucal.

\subsubsection{Grupos Controles}

Todos os pacientes que compõem os grupos controles são de origem caucasiana, canadenses, originários do arquivo de documentações Burlington Growth Centre, localizado na Faculdade de Odontologia da Universidade de Toronto, Canadá.

Como os pacientes dos grupos experimentais apresentavam inicialmente más oclusões de Classe II, selecionaram-se pacientes para os grupos controles com o mesmo tipo de má oclusão. Proporcionou-se, dessa forma, uma comparação direta entre os grupos, uma vez que os padrões craniofaciais que freqüentemente 
acompanham más oclusões não se assemelham com aqueles de oclusões normais $^{155}$.

- Grupo Controle 1, constituído por 20 pacientes, sendo 15 do gênero masculino e cinco de feminino. Com o objetivo de comparar este grupo com o grupo 1 , selecionaram-se pacientes que apresentavam telerradiografias longitudinais, em média aos 12,11 e aos 14,10 anos de idade.

- Grupo Controle 2, constituído por 31 pacientes, sendo 22 do gênero masculino e 9 do feminino. Com o objetivo de comparar este grupo com o grupo 2, selecionaram-se pacientes que apresentavam telerradiografias longitudinais, em média aos 9,08 e aos 12,11 anos de idade. A média da idade inicial estabelecida foi preferida devido à grande disponibilidade de documentações aos nove anos.

Uma vez que as idades iniciais pertencentes aos pacientes do grupo controle 2 diferiam em média 14 meses do grupo 2, houve a necessidade de reajustar as medidas cefalométricas compatibilizando as idades na análise intergrupos. Reajustaram-se todas as medidas iniciais e finais dos 31 pacientes pertencentes ao grupo controle 2, mesmo sendo a diferença média de idade final de três meses. Conduziu-se da seguinte forma o reajuste: calculou-se em meses a diferença $(x)$ entre a idade inicial e a final dos pacientes do grupo controle 2. Em seguida, para cada medida cefalométrica, subtraiu-se do valor final o inicial (y). Este resultado foi dividido por " $x$ ". Para compatibilizar com a idade média inicial do grupo experimental (10,28 anos), o resultado da divisão foi então multiplicado pelo número de meses necessários para alcançá-la, obtendo-se "z" (diferença cefalométrica da idade inicial do paciente do grupo controle 2 para a idade média inicial do grupo experimental 2). Para concluir, soma-se o valor cefalométrico inicial ao " $z$ ". Similarmente, conduziu-se o mesmo método para a idade final.

Reajuste do valor inicial de uma medida cefalométrica de um paciente do grupo controle 2 - fórmula

$$
\begin{aligned}
& \text { Ii } \rightarrow \text { idade inicial do paciente do grupo controle } 2 \\
& \text { If } \rightarrow \text { idade final do paciente do grupo controle } 2
\end{aligned}
$$


$\mathbf{C i} \rightarrow$ medida cefalométrica inicial do paciente do grupo controle 2

Cf $\rightarrow$ medida cefalométrica final do paciente do grupo controle 2

Im $\rightarrow$ idade inicial média do grupo experimental 2

$\mathbf{R} \rightarrow$ reajuste

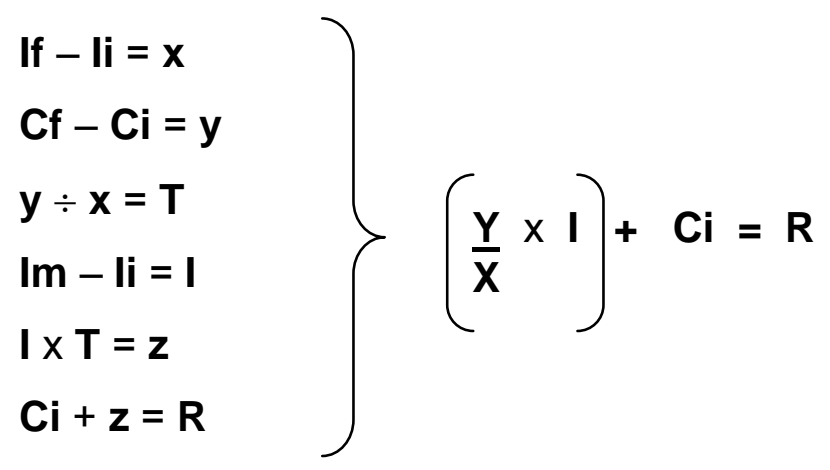

\subsubsection{Desenho dos Aparelhos e Protocolo de Tratamento}

\subsubsection{1 - Aparelho de Herbst}

Dentre as inúmeras variações encontradas na confecção e manejo clínico do aparelho de Herbst - tipo bandado ${ }^{93,94,99,127,132}$, tipo esplinte metálico ${ }^{131,132,180}$, tipo esplinte de acrílico $^{79,80,81,82,102,132,175,179}$, tipo esplinte de acrílico removível $^{81,105,115,132,142,193}$, com cantiléver ${ }^{116,132,162}$, associado à técnica Edgewise Bioprogressiva $^{42}$, sistema "Flip-Lock"112,114 ... - o atual estudo preconizou apenas pacientes tratados com um único tipo de aparelho de Herbst, o "Cantilever BiteJumper", difundido como "CBJ".

Este sistema, introduzido por Mayes ${ }^{132}$, utiliza quatro coroas de aço nos primeiros molares de ambos os arcos dentários e um cantiléver soldado nas coroas dos primeiros molares inferiores, o qual se estende em direção anterior até a área dos pré-molares e caninos para o posicionamento do pivô do arco inferior ${ }^{132}$. Utilizaram-se no grupo experimental os "Cantilever Bite-Jumpers" comercializados pela "Ormco Corporation" em que as partes constituintes dispõem-se em kits contendo todas as peças necessárias para a sua instalação, com os pivôs présoldados nas coroas superiores e nos cantiléveres inferiores. Este mecanismo, além de facilitar a aplicação clínica, reduz o serviço laboratorial, necessitando apenas da 
confecção de um arco lingual (fio de aço 1,1mm) e de um arco transpalatino (fio de aço $1,1 \mathrm{~mm}$ e $3 \mathrm{~mm}$ afastado do palato) em casos com expansão prévia superior $^{114,116}$.

Instalação

Toda a seqüência clínica necessária para a confecção, instalação e remoção dos "CBJs" nos pacientes deste grupo seguiu o padrão descrito por MORO; FUZIY; FREITAS; HENRIQUES; JANSON ${ }^{116}$, em 2002.

Após a instalação do aparelho, pedia-se ao paciente para realizar movimentos de lateralidade e de máxima abertura bucal com intuito de explicar certas limitações de movimento e de verificar também algum possível desencaixe do sistema telescópico. Caso acontecesse essa desconexão, orientava-se calmamente o paciente a reinserir o pistão no interior do tubo. Todas as instruções e informações possíveis (higiene, alimentação, desconforto imediato, cansaço muscular inicial e cuidados em geral...) eram transmitidas ao paciente, bem como aos pais ${ }^{93,115,116}$.

\section{Protocolo de tratamento}

Visando à padronização do estímulo ântero-posterior inicial com o aparelho, avançou-se a mandíbula horizontalmente numa média de $6 \mathrm{~mm}$ alcançando uma posição de topo a topo dos incisivos. Para os casos que apresentavam um trespasse horizontal maior que $6 \mathrm{~mm}$, realizava-se um avanço gradual, ou seja, passo a passo a cada dois ou três meses utilizando-se de anéis metálicos ou espaçadores com distâncias predeterminadas (de 1 a $5 \mathrm{~mm}$ ), podendo ser adicionados ao pistão unilateral ou bilateralmente em casos de desvio da linha média. Considerou-se também que, durante o avanço da mandíbula, se ocorresse um cruzamento da mordida nos segmentos posteriores, a expansão rápida da maxila anterior à colocação do aparelho de Herbst seria necessária. Preconizou-se, nestes casos, o aparelho Expansor tipo Hyrax para a correção da deficiência transversal previamente à instalação do mecanismo telescópico. 
Durante o primeiro mês, após a instalação do Herbst, checagens clínicas eram agendadas em períodos mais próximos, conferindo a adaptabilidade psíquica e muscular dos pacientes. Após este período mais crítico de adaptação, manutenções eram realizadas mensalmente, conferindo todos os aspectos intrabucais, além das adaptações dos espaçadores quando necessários.

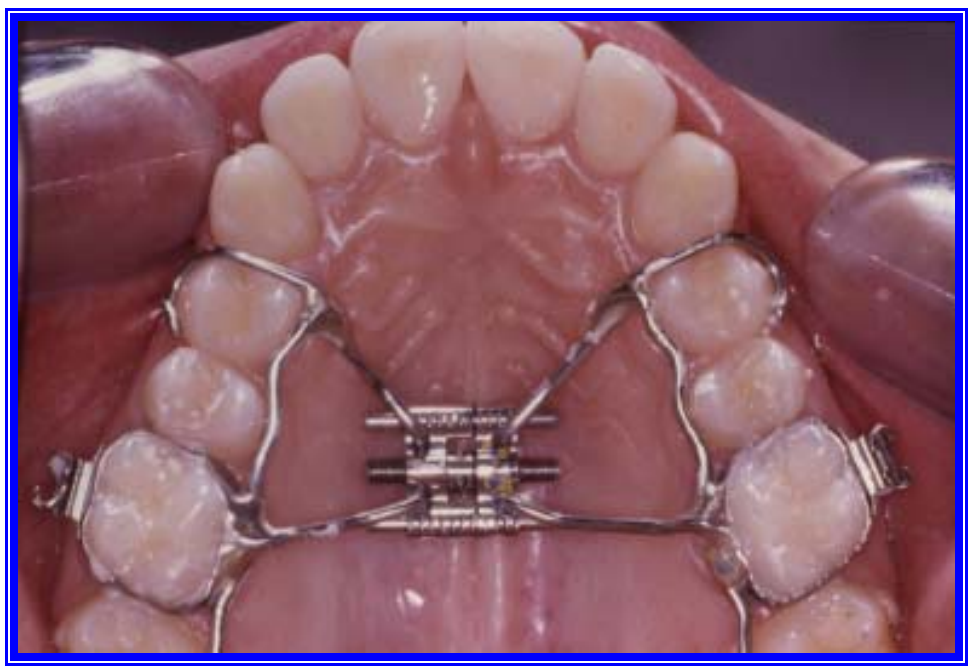

FIGURA A - Aparelho Expansor tipo Hyrax; foto oclusal superior

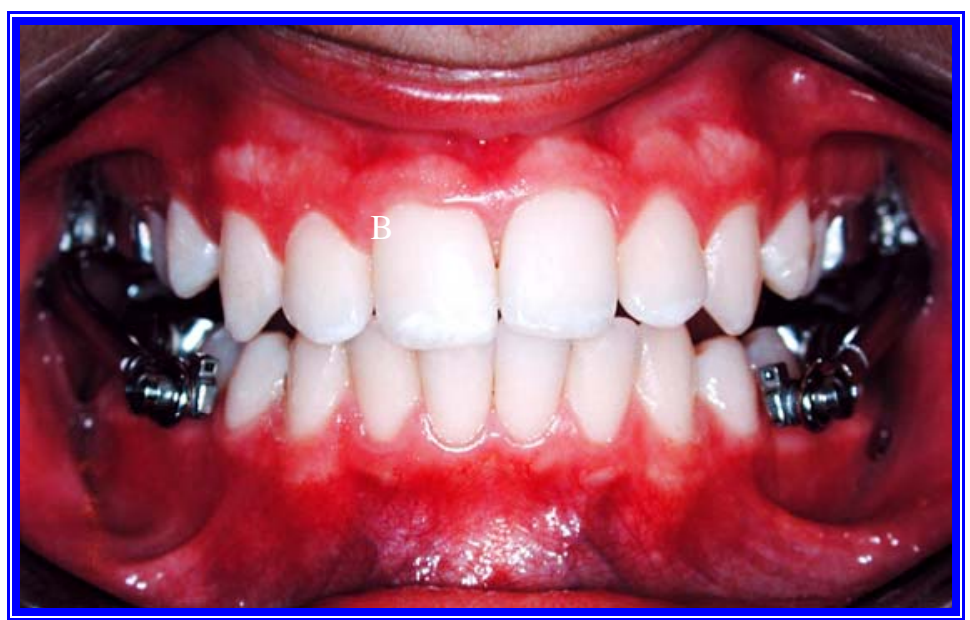

FIGURA B - Aparelho de Herbst; foto intrabucal frontal 


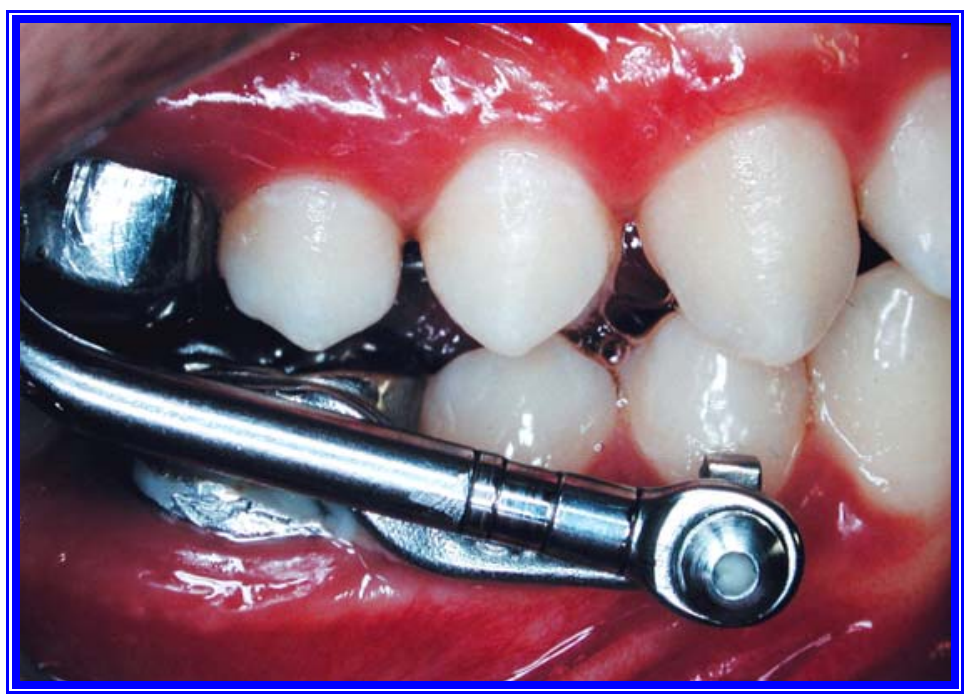

FIGURA C - Aparelho de Herbst; foto intrabucal lateral

\subsubsection{2 - Aparelho Extrabucal de tração occipital}

Dentre as diferentes modalidades de ancoragem extrabucal ${ }^{73,88,152,171}$, classificando-se quanto à direção de tração em alta ou parietal, média ou occipital e baixa ou cervical, este estudo preconizou apenas pacientes tratados com um único tipo de aparelho extrabucal, o de tração média ou occipital, difundido como I.H.G. que abrevia a denominação "Interlandi Headgear" ${ }^{49}$. Esse sistema de ancoragem extrabucal, idealizado por Interlandi ${ }^{9}$, constitui-se de um casquete compreendido por tiras de apoio em número de três, que se adaptam nas áreas cervical, occipital e parietal, juntam-se à frente do pavilhão auditivo por meio de uma lâmina plástica em forma de $\mathrm{C}$, com ranhuras na borda interna permitindo variar a direção dos elásticos, os quais tracionam o arco externo e este, por sua vez, o interno, que se encontra ajustado nos tubos molares.

Instalação

Instalaram-se, nos primeiros molares superiores, as bandas ortodônticas com os respectivos tubos para a adaptação do arco interno. Em seguida, ajustou-se o arco facial, levando em consideração as seguintes características: localizado passivamente entre os lábios; centralizado com a linha média do paciente; $6 \mathrm{~mm}$ afastado dos incisivos centrais superiores; $3 \mathrm{~mm}$ afastado dos tubos molares; arco 
interno paralelo ao plano oclusal; e o arco externo, ao redor de $1 \mathrm{~cm}$ a mais que o comprimento do interno. Finalmente, adaptava-se o casquete na cabeça do paciente e os elásticos (tamanho 1/2", com uma magnitude média de força de 400 gramas por lado) aos encaixes de graduações 3 e 5 ou 4 e 6 bilateralmente. A força do aparelho, liberada pelos elásticos, era ajustada tornando possível que sua linha de ação passasse aproximadamente pelo centro de resistência do primeiro molar superior (área de trifurcação das raízes do molar $^{181}$ ) e com uma direção para superior e posterior.

\section{Protocolo de tratamento}

Orientaram-se os pacientes a utilizarem os aparelhos Extrabucais de forma adequada e pelo maior número de horas contínuas por dia, com exceção durante as refeições, escovações dentárias e na prática de esportes, com um tempo médio de uso de 15 horas. Preconizou-se a troca de elásticos a cada três dias.

As manutenções eram realizadas mensalmente com o objetivo de conferir as características do arco facial, mobilidade dos primeiros molares superiores, alterações oclusais alcançadas e averiguar se realmente todos os pacientes estavam utilizando o aparelho conforme o recomendado. Era essencial manter constante a ativação e a direção da força dos elásticos durante todo o tratamento.

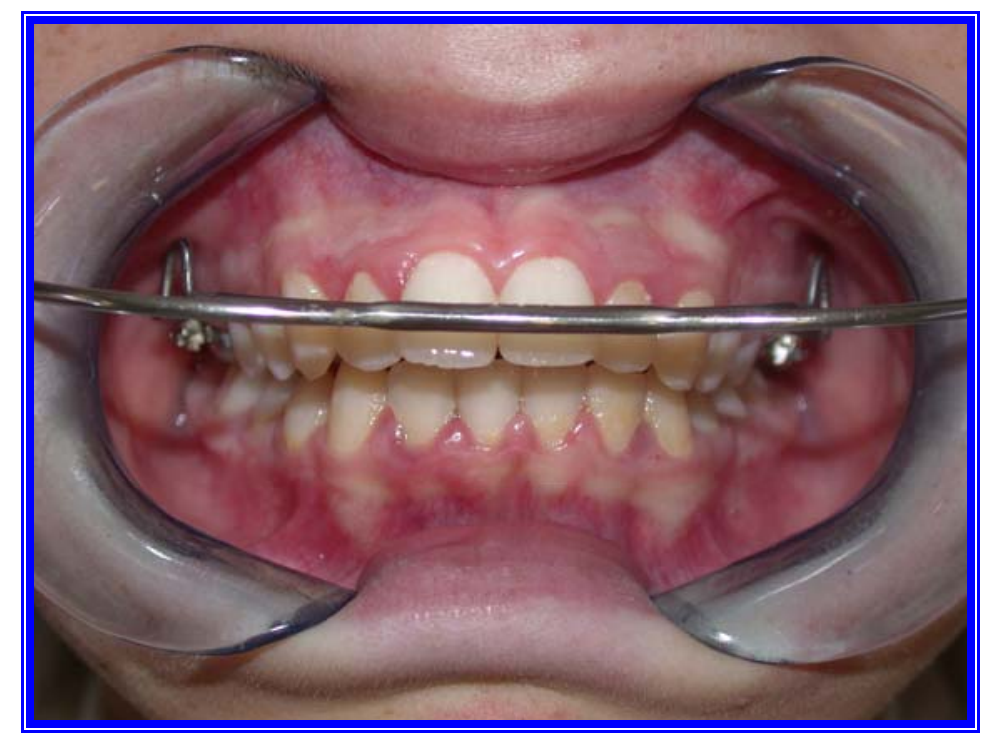

FIGURA D - Arco facial; foto intrabucal frontal 


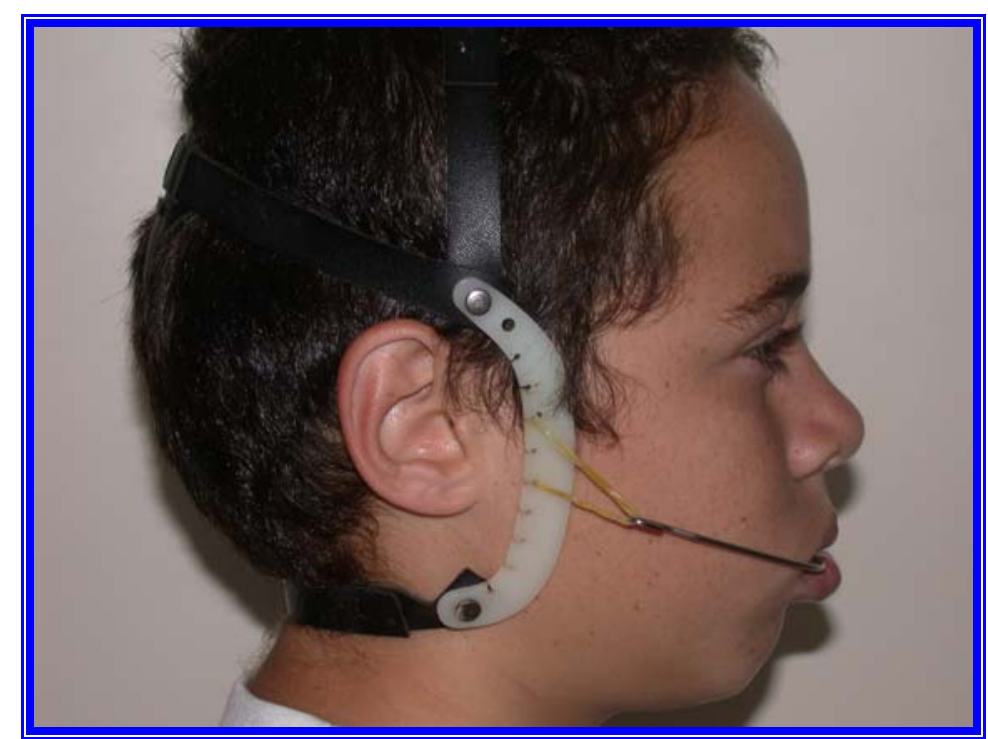

FIGURA E - Aparelho Extrabucal de tração occipital; foto extrabucal lateral

\subsection{Métodos}

\subsubsection{Radiografias Cefalométricas}

Utilizaram-se telerradiografias de todos os pacientes pertencentes a este estudo. Designou-se como $\mathrm{T}_{1}$ a radiografia inicial - obtida antes da colocação do aparelho nos grupos experimentais e no início do período de observação dos grupos controles, e $\mathrm{T}_{2}$ a radiografia final - obtida imediatamente após a remoção dos aparelhos e no final do período de observação dos grupos controles. As radiografias dos pacientes, mesmo sendo obtidas em aparelhos distintos, seguiram um similar padrão nas suas tomadas radiográficas, com o posicionamento da cabeça orientado pelo cefalostato, mantendo o plano sagital mediano do paciente perpendicular e o plano horizontal de Francfurt paralelo, ambos em relação ao solo. Orientavam-se os pacientes para que os lábios permanecessem em repouso, e a mandíbula mantida em máxima intercuspidação habitual. Os critérios convencionalmente aceitos de processamento dos filmes radiográficos foram obedecidos para todos os grupos.

As radiografias pertencentes ao grupo 1, Controle 1 e Controle 2 apresentaram um fator de ampliação da imagem radiográfica da ordem de 9,8\%. No grupo 2, alguns pacientes apresentaram um fator de ampliação da ordem de 9,8\% e outros de 10,9\%. Esta diferença de ampliação da imagem foi ajustada (no programa 
cefalométrico), para que todos os grupos fossem comparáveis. Ressalta-se que as duas radiografias, inicial e final de cada paciente, foram obtidas no mesmo aparelho radiográfico, apresentando o mesmo fator de ampliação.

\subsubsection{Elaboração do Cefalograma}

Traçaram-se as telerradiografias manualmente sobre o negatoscópio, pelo pesquisador, emoldurado com cartolina, expondo-se as áreas correspondentes ao desenho anatômico. Seguiram-se as orientações fornecidas por VION ${ }^{195}$, para uma melhor localização e demarcação das estruturas anatômicas, e conseqüentemente a obtenção de uma maior exatidão dos pontos cefalométricos. Requereram-se os seguintes materiais: folha de papel acetato transparente "Ultraphan" de tamanho $17,5 \mathrm{~cm}$ de largura por $17,5 \mathrm{~cm}$ de comprimento e espessura de $0,07 \mathrm{~mm}$, adaptada com fita adesiva sobre a telerradiografia; lapiseira com grafite preto 0.5 ; template (para a padronização dos desenhos dos incisivos e molares superiores e inferiores) e borracha branca macia. Permaneceram-se escurecidos os locais de trabalho durante a execução dos traçados. Todos os desenhos anatômicos foram digitalizados por meio de uma mesa digitalizadora Houston Instruments DT-11 (Houston Instruments Austin, Texas, USA), transferindo-se a localização dos pontos do desenho para o programa de Cefalometria Dentofacial Planner 7.02 (Dentofacial Planner Software Inc., Toronto, Ontario, Canada) para o processamento das mensurações, envolvendo as linhas e os planos pré-determinados. Conferiram-se as imagens dos dados com os pontos demarcados nos desenhos anatômicos, assegurando-se a exatidão.

Utilizaram-se os pontos médios das estruturas bilaterais (pares), durante a demarcação dos pontos cefalométricos e padronizaram-se os desenhos dos incisivos superiores e inferiores e dos primeiros molares superiores e inferiores com a utilização do template. 
4.2.2.1 - Delimitação das estruturas dento-esqueléticas e do perfil tegumentar (Figura 1)

O traçado obedeceu aos seguintes detalhes anatômicos:

> Contorno do perfil tegumentar $\rightarrow$ a partir da metade inferior da fronte até completar o contorno do mento, interrompido na altura dos lábios quando entreabertos.

> Perfil do osso frontal e dos ossos nasais $\rightarrow$ contorno exterior do osso frontal (glabela) e o limite anterior dos ossos nasais unidos entre si pela sutura frontonasal.

Órbita $\rightarrow$ contorno póstero-inferior das cavidades orbitárias.

Sela túrcica $\rightarrow$ contorno anterior, inferior e posterior da sela, estendendo-se anterior e, posteriormente, abrangendo os processos clinóides anterior e posterior e o contorno do clívus do osso esfenóide.

$>$ Fissura pterigomaxilar $\rightarrow$ limite posterior da tuberosidade maxilar e anterior do processo pterigóide do osso esfenóide.

$>$ Meato acústico externo $\rightarrow$ contorno da imagem radiolúcida do meato acústico externo.

> Maxila $\rightarrow$ contorno da concavidade anterior, desde a espinha nasal anterior até próximo à região cervical das coroas dos incisivos, estendendo-se posteriormente da espinha nasal anterior até a posterior, por sobre a cortical do assoalho das fossas nasais, completando-se o desenho com uma linha correspondente ao limite inferior da região anterior do palato duro.

Mandíbula $\rightarrow$ contorno da cortical externa da sínfise e média das bordas do corpo mandibular, dos ramos ascendentes e dos côndilos.

$>$ Incisivos centrais permanentes superiores e inferiores mais vestibularizados $\rightarrow$ contorno das coroas e raízes dentárias. 
Primeiros molares permanentes superiores e inferiores $\rightarrow$ contorno das coroas e raízes dentárias.

\section{DESENHO ANATÔMICO}

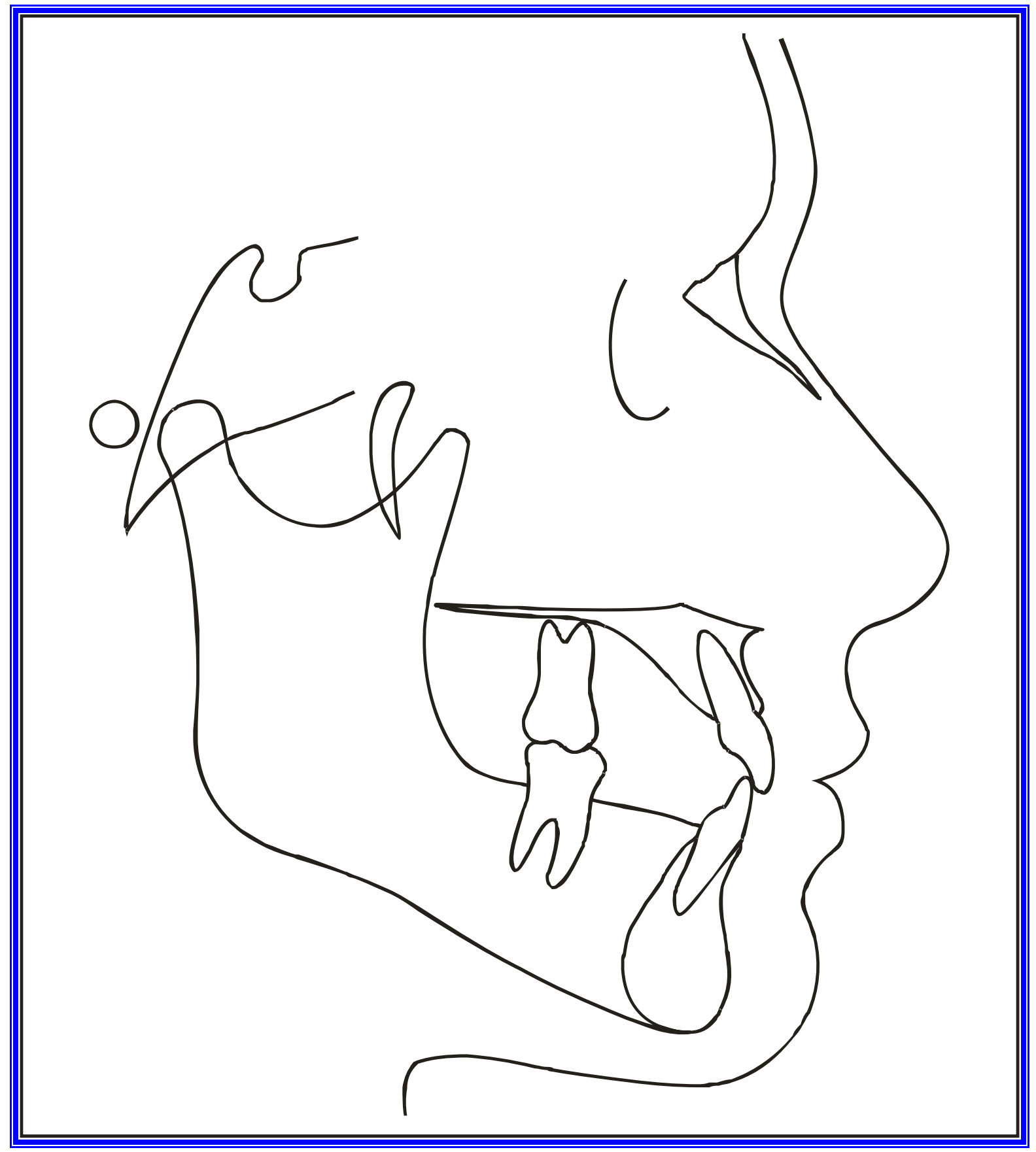

FIGURA 1 - Delimitação das estruturas dento-esqueléticas e do perfil tegumentar 
4.2.2.2 - Demarcação dos pontos cefalométricos de referência (Figura 2)

\begin{tabular}{|c|c|c|}
\hline Número & Abreviação & Definição \\
\hline 1 & Prn & Pronasal - ponto mais anterior da extremidade nasal \\
\hline 2 & Prn' & $\begin{array}{l}\text { Columela - ponto mais proeminente, na margem } \\
\text { inferior da columela do nariz, localizado entre o } \\
\text { pronasal e o subnasal }\end{array}$ \\
\hline 3 & Sn & $\begin{array}{l}\text { Subnasal - ponto de confluência entre a margem } \\
\text { inferior da columela do nariz e do lábio superior }\end{array}$ \\
\hline 4 & Ls & $\begin{array}{l}\text { Lábio superior - ponto mais anterior do vermelhão do } \\
\text { lábio superior }\end{array}$ \\
\hline 5 & Li & $\begin{array}{l}\text { Lábio inferior - ponto mais anterior do vermelhão do } \\
\text { lábio inferior }\end{array}$ \\
\hline 6 & Pog' & $\begin{array}{l}\text { Pogônio tegumentar - ponto mais anterior do mento } \\
\text { no perfil tegumentar }\end{array}$ \\
\hline 7 & $\mathbf{N}$ & Násio - ponto mais anterior da sutura frontonasal \\
\hline 8 & Or & $\begin{array}{l}\text { Orbitário - ponto mais inferior da margem inferior da } \\
\text { órbita }\end{array}$ \\
\hline 9 & ENP & $\begin{array}{l}\text { Espinha nasal posterior - ponto mais posterior da } \\
\text { espinha nasal do osso palatino, no palato duro }\end{array}$ \\
\hline 10 & ENA & $\begin{array}{l}\text { Espinha nasal anterior - ponto mais anterior da } \\
\text { espinha nasal anterior }\end{array}$ \\
\hline 11 & A & $\begin{array}{l}\text { Subespinhal - ponto mais profundo na concavidade do } \\
\text { contorno anterior da maxila, entre a espinha nasal } \\
\text { anterior e o ponto próstio }\end{array}$ \\
\hline 12 & AIS & $\begin{array}{l}\text { Ápice do incisivo superior - ponto mais superior do } \\
\text { ápice radicular do incisivo central superior }\end{array}$ \\
\hline 13 & IIS & $\begin{array}{l}\text { Incisal do incisivo superior - ponto mais inferior da } \\
\text { coroa do incisivo central superior }\end{array}$ \\
\hline 14 & AMS & $\begin{array}{l}\text { Ápice do molar superior - ponto mais superior do } \\
\text { ápice radicular da raiz mésio-vestibular do primeiro } \\
\text { molar superior }\end{array}$ \\
\hline 15 & CMMS & $\begin{array}{l}\text { Cúspide mésio-vestibular do molar superior - ponto } \\
\text { mais inferior da cúspide mésio-vestibular do primeiro } \\
\text { molar superior }\end{array}$ \\
\hline 16 & CMMI & $\begin{array}{l}\text { Cúspide mésio-vestibular do molar inferior - ponto } \\
\text { mais superior da cúspide mésio-vestibular do primeiro }\end{array}$ \\
\hline
\end{tabular}


molar inferior

$17 \quad$ AMI

18

19

20

21

22

Pog

23

24 Goln

25 Go

26 Co

$27 \quad$ Po

28 S

29

30
Me

SMCMMS

SMCMMI

Ápice do molar inferior - ponto mais inferior do ápice radicular da raiz mesial do primeiro molar inferior Incisal do incisivo inferior - ponto mais superior da coroa do incisivo central inferior

Ápice do incisivo inferior - ponto mais inferior do ápice radicular do incisivo central inferior

Supramentoniano - ponto mais profundo da concavidade da sínfise mentoniana

Pogônio - ponto mais anterior da sínfise mentoniana Gnátio - ponto localizado no mento, determinado geometricamente pela intersecção da bissetriz do ângulo formado pelos planos mandibular (Go-Me) e facial (N-P), com a sínfise mentoniana

Mentoniano - ponto mais inferior da sínfise mentoniana

Gônio inferior - ponto mais inferior do ângulo goníaco

Gônio - ponto médio entre os pontos mais inferior e posterior do ângulo goníaco

Condílio - ponto mais póstero-superior do côndilo mandibular

Pório - ponto mais superior do meato acústico externo Sela túrcica - ponto mais central da sela túrcica

Superfície mesial da cúspide mésio-vestibular do molar superior - ponto mais anterior da coroa do primeiro molar superior

Superfície mesial da cúspide mésio-vestibular do molar inferior - ponto mais anterior da coroa do primeiro molar inferior 


\section{PONTOS CEFALOMÉTRICOS}

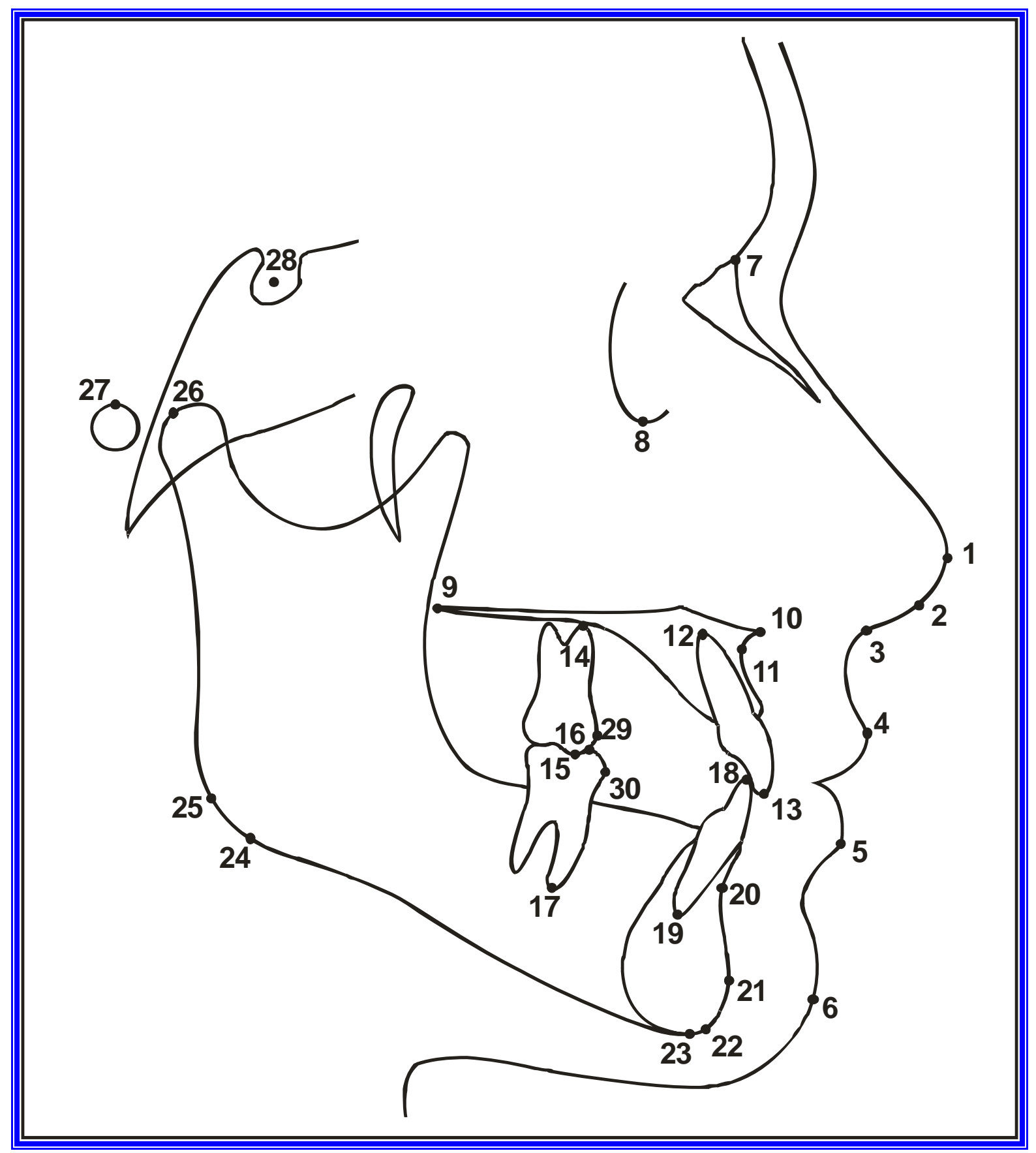

FIGURA 2 - Demarcação dos pontos de referência no desenho anatômico; a demarcação e enumeração destes pontos seguiram a seqüência préestabelecida pelo programa de análise cefalométrica $D F P$, Toronto, $C A$ 
4.2.2.3 - Planos e linhas de referência (Figura 3)

1. Linha SN Linha que passa pelos pontos S e N

2. Linha NA

3. Linha NB

4. Linha APog

5. Plano mandibular (Goln - Me)

6. Plano mandibular $\mathrm{T}(\mathrm{Go}-\mathrm{Me})$

7. Plano horizontal de Francfort

8. Plano palatino (PP)

9. Plano oclusal (PO)

10. Linha S Perp
Linha que passa pelos pontos $\mathrm{N}$ e $\mathrm{A}$

Linha que passa pelos pontos $\mathrm{N}$ e $\mathrm{B}$

Linha que passa pelos pontos A e Pog

Plano que passa pelos pontos Goln e Me

Plano que passa pelos pontos Go e Me

Plano que passa pelos pontos Po e Or

Plano que passa pelos pontos ENA e ENP

Plano que passa pela média dos pontos CMMS e do CMMI e dos pontos IIS e do III

Linha perpendicular ao plano oclusal passando pelo ponto sela

11. Linha do longo eixo do incisivo Linha que passa pelos pontos IIS e AIS superior

12. Linha do longo eixo do primeiro Linha que passa pelos pontos CMMS e AMS molar superior

13. Linha do longo eixo do incisivo Linha que passa pelos pontos III e All inferior

14. Linha do longo eixo do primeiro Linha que passa pelos pontos CMMI e AMI molar inferior

15. Linha SnPrn'

Linha que passa pelos pontos Sn e Prn'

16. Linha SnLs

Linha que passa pelos pontos Sn e Ls

17. Linha E

Linha que passa pelos pontos Prn e Pog' 


\section{LINHAS E PLANOS CEFALOMÉTRICOS}

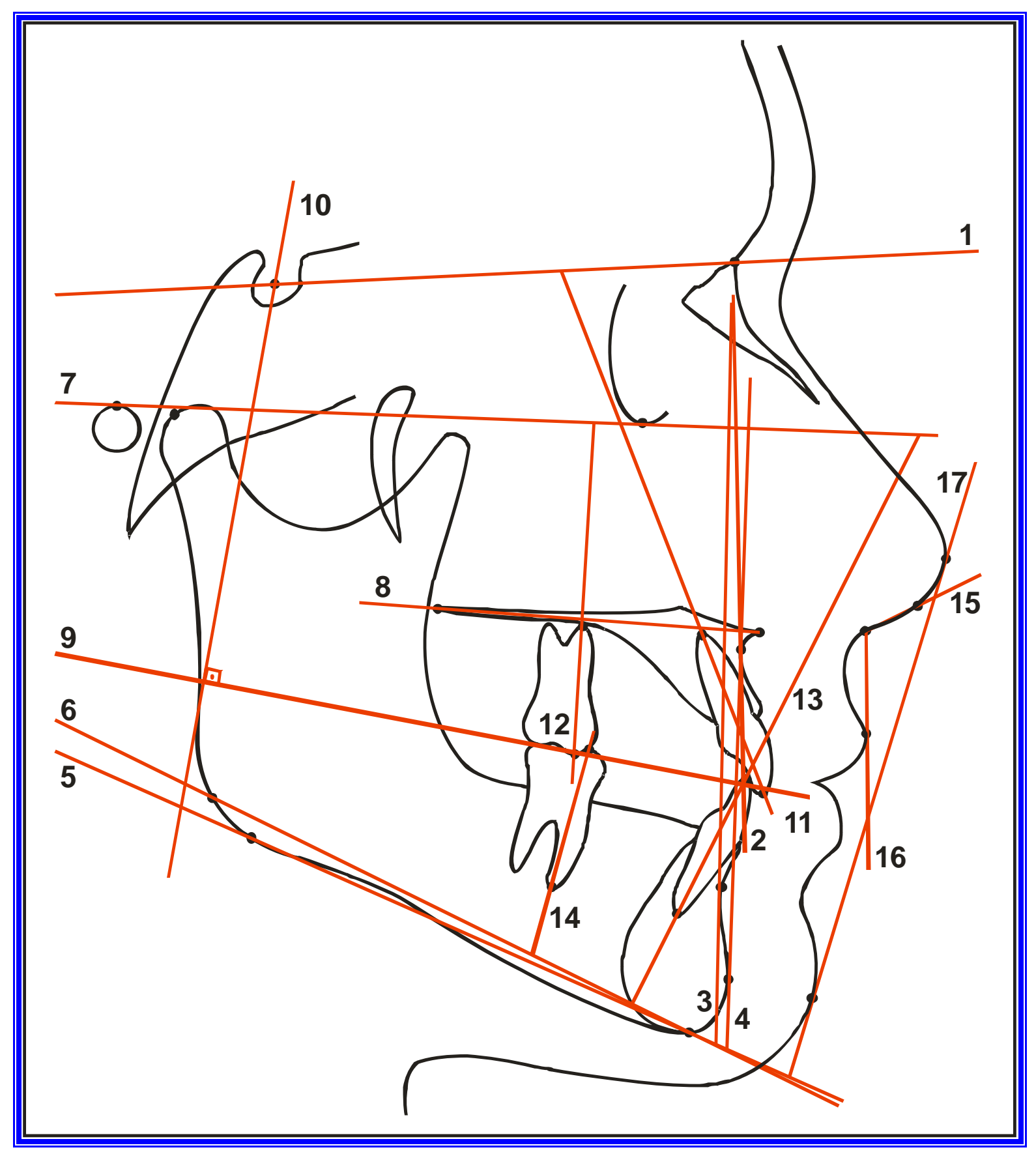

FIGURA 3 - Linhas e planos de referência que constituíram o traçado de orientação dos cefalogramas 
O conjunto de planos e linhas de referência adotados possibilitou a interpretação de 33 grandezas cefalométricas, sendo 14 angulares e 19 lineares. Estas grandezas são derivadas de diversas análises como: Steiner ${ }^{182}$, Riedel ${ }^{159}$, Tweed $^{188}$, Downs $^{43}$, Ricketts ${ }^{157}$, McNamara Júnior ${ }^{101}$ e Pancherz ${ }^{50,126,128,137,138,}$.

4.2.2.4 - Grandezas cefalométricas utilizadas na avaliação do componente maxilar (Figura 4)

1. S.N.A Ângulo formado pelas linhas SN e NA

2. Co-A

Distância do ponto Co ao ponto A

4.2.2.5 - Grandezas cefalométricas utilizadas na avaliação do componente mandibular (Figura 4)

3. S.N.B Ângulo formado pelas linhas SN e NB
4. Co-Gn
Distância do ponto Co ao Gn

4.2.2.6 - Grandezas cefalométricas utilizadas na avaliação da relação maxilomandibular (Figura 4)

5. A.N.B Diferença dos ângulos S.N.A e S.N.B

6. N.A.Pog

Ângulo formado pelas linhas NA e APog 
COMPONENTES MAXILAR, MANDIBULAR E RELAÇÃO MAXILOMANDIBULAR

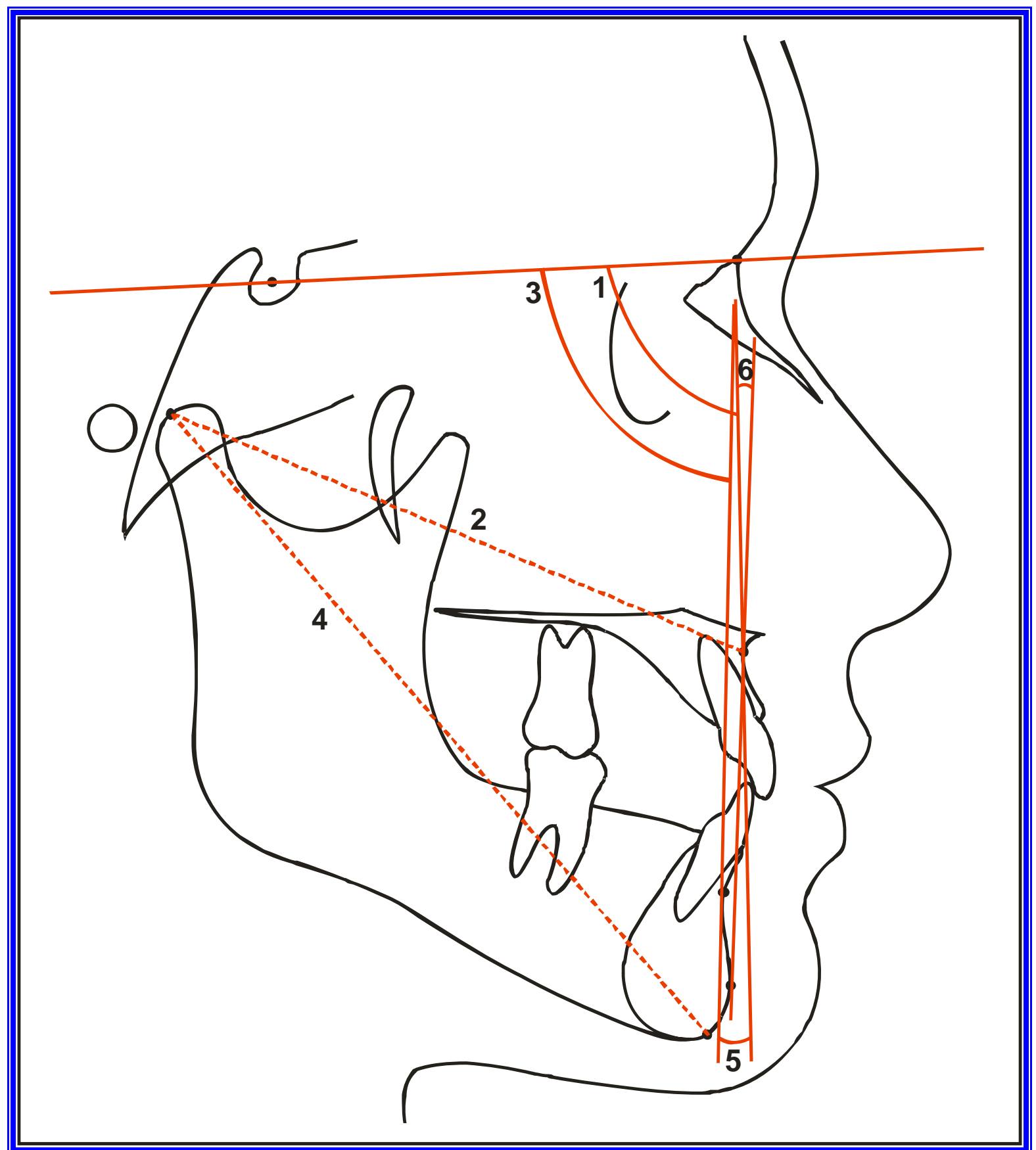

FIGURA 4 - Grandezas lineares e angulares na avaliação dos componentes maxilar, mandibular e relação maxilomandibular 
4.2.2.7 - Grandezas cefalométricas utilizadas na avaliação do componente vertical (Figura 5)

7. PoOr.PP

Ângulo formado pelo plano horizontal de Francfort e pelo plano palatino

8. PoOr.GolnMe Ângulo formado pelo plano horizontal de Francfort e pelo plano mandibular

9. PoOr.PO Ângulo formado pelo plano horizontal de

10. ENA-Me (AFAI) Francfort e pelo plano oclusal Distância entre os pontos ENA e Me

11. N-Me

Distância entre os pontos $\mathrm{N}$ e Me

12.S-Go

Distância entre os pontos S e Go 
COMPONENTE VERTICAL

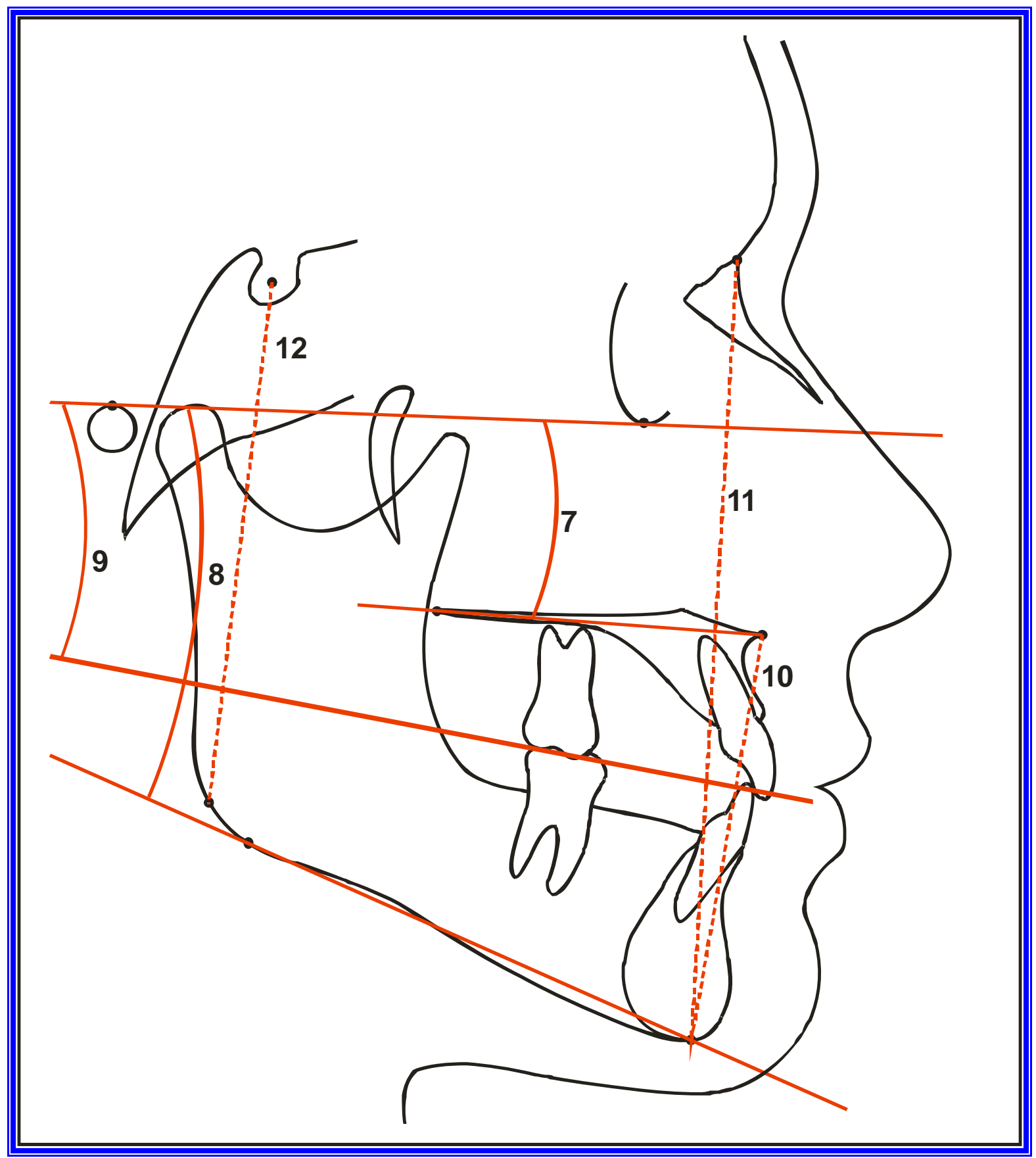

FIGURA 5 - Grandezas lineares e angulares na avaliação do componente vertical 
4.2.2.8 - Grandezas cefalométricas utilizadas na avaliação do componente dentoalveolar superior (Figura 6)

\begin{tabular}{|c|c|}
\hline 13.1.NA & $\begin{array}{l}\text { Ângulo formado pela linha do longo eixo } \\
\text { do incisivo superior com a linha NA }\end{array}$ \\
\hline 14.1-NA & $\begin{array}{l}\text { Distância linear entre a incisal do incisivo } \\
\text { superior e a linha NA }\end{array}$ \\
\hline 15.1.PP & $\begin{array}{l}\text { Ângulo formado pela linha do longo eixo } \\
\text { do incisivo superior com o plano palatino }\end{array}$ \\
\hline 16.1-PP & $\begin{array}{l}\text { Distância entre a incisal do incisivo } \\
\text { superior e o plano palatino }\end{array}$ \\
\hline 17.‥PP & $\begin{array}{l}\text { Ângulo formado pela linha do longo eixo } \\
\text { do primeiro molar superior com o plano } \\
\text { palatino }\end{array}$ \\
\hline 18. $\underline{6}-\mathrm{PP}$ & $\begin{array}{l}\text { Distância entre a cúspide mésio- } \\
\text { vestibular do molar superior e o plano } \\
\text { palatino }\end{array}$ \\
\hline 19.1- SPerp & $\begin{array}{l}\text { Distância entre a incisal do incisivo } \\
\text { superior e a linha S Perp }\end{array}$ \\
\hline 20.6- SPerp & $\begin{array}{l}\text { Distância entre a superfície mesial da } \\
\text { cúspide mésio-vestibular do molar } \\
\text { superior e a linha S Perp }\end{array}$ \\
\hline
\end{tabular}


COMPONENTE DENTO-ALVEOLAR SUPERIOR

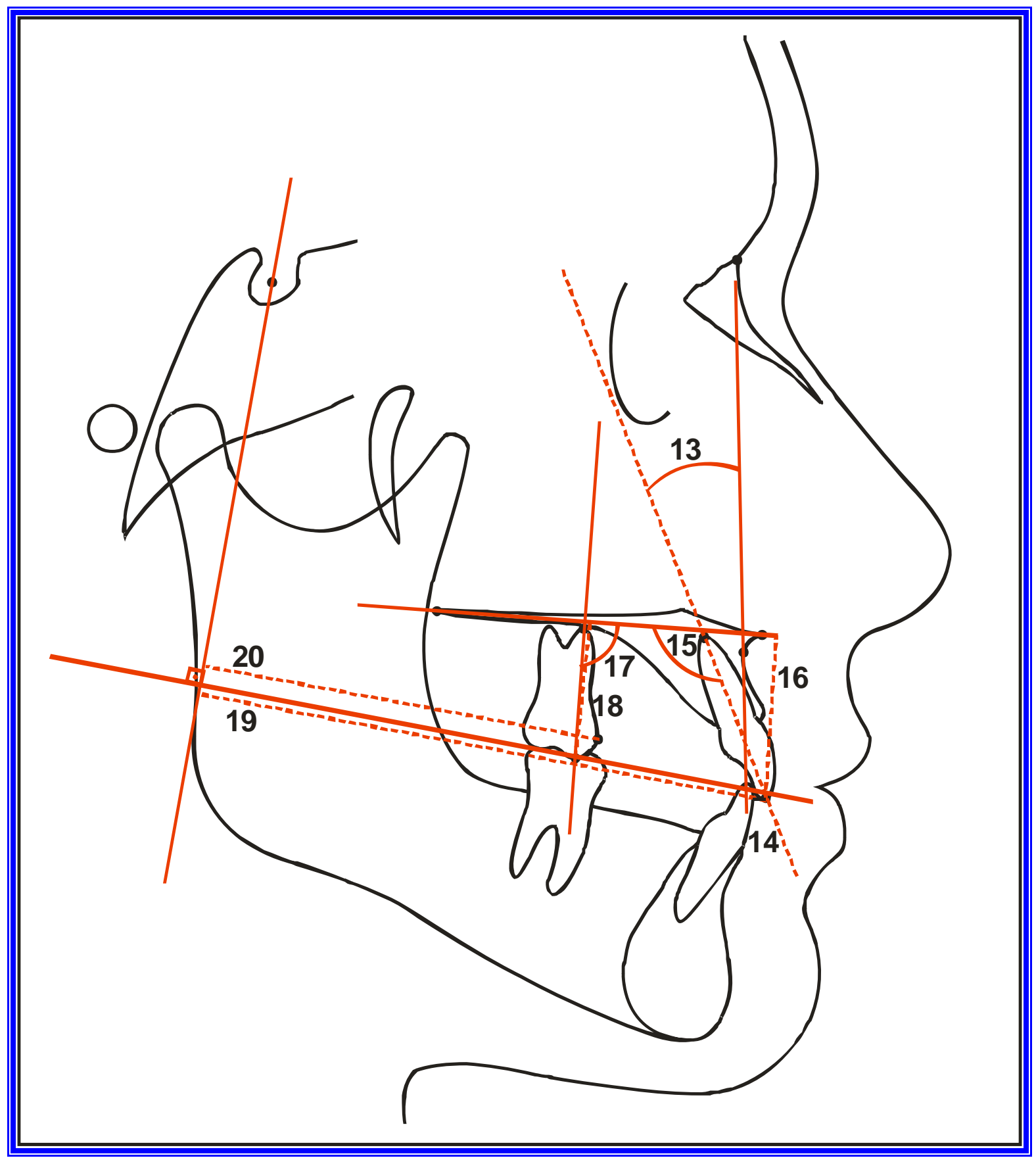

FIGURA 6 - Grandezas lineares e angulares na avaliação do componente dento-alveolar superior 
4.2.2.9 - Grandezas cefalométricas utilizadas na avaliação do componente dentoalveolar inferior (Figura 7)

\begin{tabular}{|c|c|}
\hline 21.1.NB & $\begin{array}{l}\text { Ângulo formado pela linha do longo eixo } \\
\text { do incisivo inferior com a linha NB }\end{array}$ \\
\hline 22.1-NB & $\begin{array}{l}\text { Distância linear entre a incisal do incisivo } \\
\text { inferior e a linha NB }\end{array}$ \\
\hline 23.1.GolnMe & $\begin{array}{l}\text { Ângulo formado pela linha do longo eixo } \\
\text { do incisivo inferior com o plano } \\
\text { mandibular }\end{array}$ \\
\hline 24.1-GolnMe & $\begin{array}{l}\text { Distância entre a incisal do incisivo } \\
\text { inferior e o plano mandibular }\end{array}$ \\
\hline 25.6.GoMe & $\begin{array}{l}\text { Ângulo formado pela linha do longo eixo } \\
\text { do primeiro molar inferior com o plano } \\
\text { mandibular } \mathrm{T}\end{array}$ \\
\hline 26.6-GoMe & $\begin{array}{l}\text { Distância entre a cúspide mésio- } \\
\text { vestibular do molar inferior e o plano } \\
\text { mandibular T }\end{array}$ \\
\hline 27.1- SPerp & $\begin{array}{l}\text { Distância entre a incisal do incisivo } \\
\text { inferior e a linha S Perp }\end{array}$ \\
\hline 28.6- SPerp & $\begin{array}{l}\text { Distância entre a superfície mesial da } \\
\text { cúspide mésio-vestibular do molar inferior } \\
\text { e a linha S Perp }\end{array}$ \\
\hline
\end{tabular}


COMPONENTE DENTO-ALVEOLAR INFERIOR

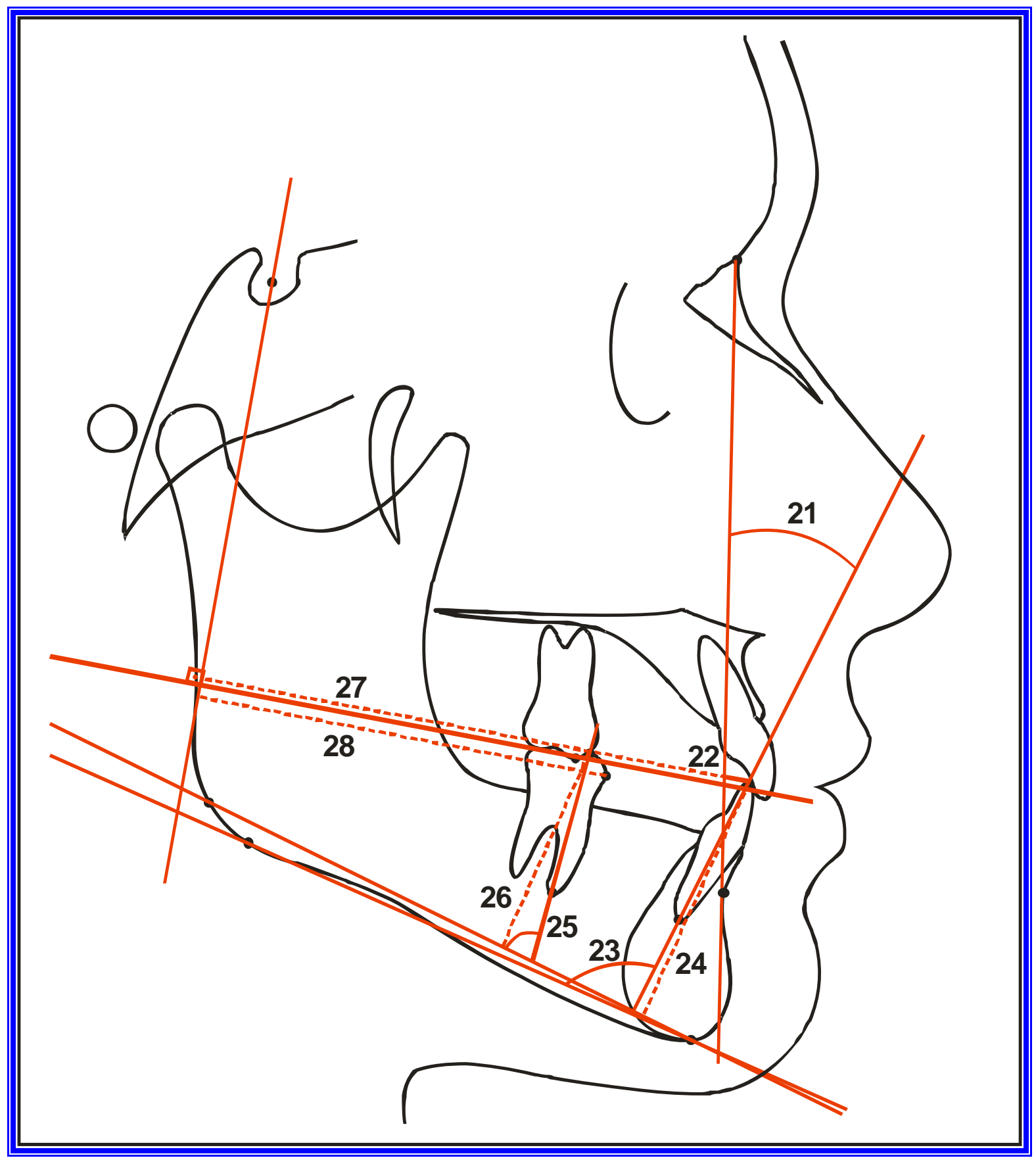

FIGURA 7 - Grandezas lineares e angulares na avaliação do componente dento-alveolar inferior 
4.2.2.10 - Grandezas cefalométricas utilizadas na avaliação da relação interdentária (Figura 8)

\begin{tabular}{|l|l|}
\hline 29.Sobressaliência & $\begin{array}{l}\text { Distância horizontal entre a incisal do } \\
\text { incisivo superior e a incisal do incisivo } \\
\text { inferior }\end{array}$ \\
\hline 30. Relação molar & $\begin{array}{l}\text { Distância horizontal entre a cúspide } \\
\text { mésio-vestibular do molar superior e a } \\
\text { cúspide mésio-vestibular do molar inferior }\end{array}$ \\
\hline
\end{tabular}

\section{RELAÇÃO INTERDENTÁRIA}

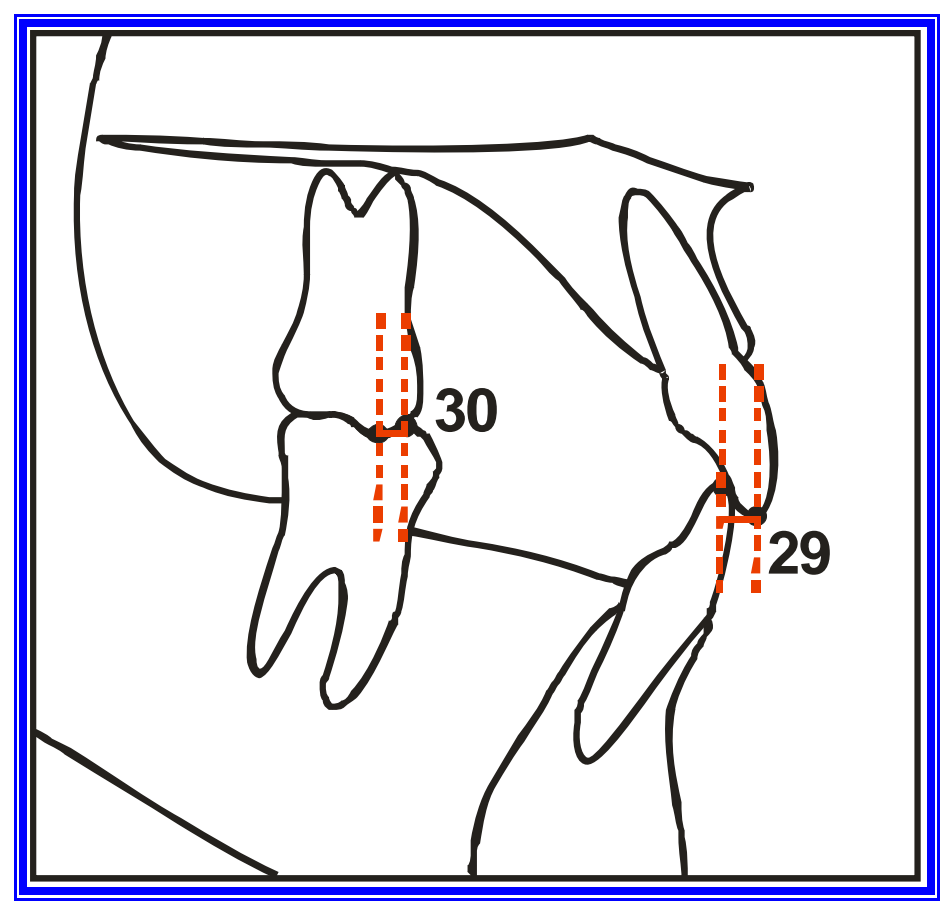

FIGURA 8 - Grandezas lineares na avaliação da relação interdentária 
4.2.2.11 - Grandezas cefalométricas utilizadas na avaliação do componente tegumentar (Figura 9)

\begin{tabular}{|c|c|}
\hline 31. Ângulo nasolabial & $\begin{array}{l}\text { Ângulo formado pela linha SnPrn'e a } \\
\text { linha SnLs }\end{array}$ \\
\hline 32. Ls - PrnPog' & Distância entre Ls e a linha $\mathrm{E}$ \\
\hline 33. Li - PrnPog' & Distância entre Li e a linha $\mathrm{E}$ \\
\hline
\end{tabular}

COMPONENTE TEGUMENTAR

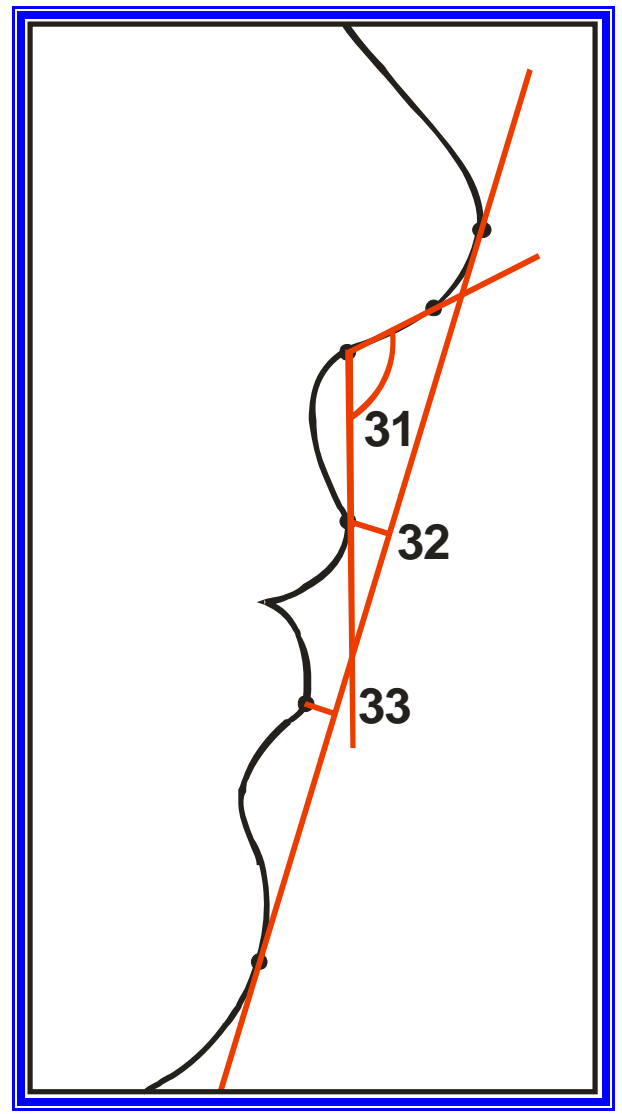

FIGURA 9 - Grandezas lineares e angulares na avaliação do componente tegumentar 


\subsubsection{Erro do Método}

Determinou-se a confiabilidade dos resultados da pesquisa, selecionandose ao acaso 46 telerradiografias ${ }^{12}$ provenientes de pacientes pertencentes aos grupos controles, que foram retraçadas e redigitalizadas pelo examinador, uma semana após a finalização de todos os traçados dos quatro grupos.

Obteve-se o erro casual de cada grandeza cefalométrica estudada de acordo com a fórmula proposta por Dahlberg $E^{2}=\sum d^{2} / 2 n$ (na qual: "d" indica a diferença entre os valores medidos na $1^{\mathrm{a}}$ e $2^{\mathrm{a}}$ mensuração e " $n$ " indica o número de casos em que as medidas foram repetidas) e o erro sistemático, pelo teste t pareado. Adicionalmente, aplicou-se o coeficiente de correlação de Pearson entre as $1^{\mathrm{a}} \mathrm{s}$ e $2^{\mathrm{a}} \mathrm{s}$ mensurações efetuadas.

\subsubsection{Análise Estatística}

Realizaram-se os testes estatísticos no programa SPSS, versão 10.1, para Windows. Para avaliar os dados obtidos, efetuaram-se as seguintes análises estatísticas:

- Estatística descritiva, envolvendo o cálculo da média e do desvio padrão, de cada variável cefalométrica nas distintas fases do estudo ( $T_{1}$ e $\left.T_{2}\right)$, para cada grupo;

- Para determinar o grau de similaridade entre arquiteturas craniofaciais antes da instituição de qualquer tratamento, os grupos experimentais foram comparados com os seus respectivos grupos controles pelo teste t;

- Para determinar se ocorreram alterações estatisticamente significantes com o tratamento ou com o crescimento entre os dois períodos de observação $\left(T_{1}, T_{2}\right)$, em cada grupo, realizou-se o teste t pareado (comparação intragrupos); 
- Para comparar as alterações decorrentes do tratamento instituído nos grupos experimentais, com as alterações normais do crescimento nos respectivos grupos controles, utilizou-se o teste $\mathrm{t}$.

Em todas as análises estatísticas empregadas, foram considerados estatisticamente significantes os resultados com valores de $p<0,05$. 
5- RESULTADOS 
Os valores individuais de cada paciente, para todas as variáveis estudadas, divididos de acordo com o grupo experimental e controle, encontram-se na seção do Apêndice.

Os resultados provenientes do cálculo do erro do método intra-examinador serão apresentados na tabela 1, enquanto que os resultados das análises estatísticas serão apresentados nas tabelas 2, 3, 4, 5, 6, 7, 8 e 9.

Todas as análises estatísticas envolvendo o Grupo 1 e o Grupo Controle 1 serão apresentadas inicialmente, prosseguindo com as estatísticas envolvendo o Grupo 2 e o Grupo Controle 2.

Os dados obtidos das tabelas 5 e 9, que representam a comparação entre as alterações decorrentes do tratamento instituído e as alterações normais do crescimento, serão visualizados, adicionalmente, por representações gráficas. 
TABELA 1 - Cálculo do erro do método intra-examinador. Erro casual (Dahlberg), erro sistemático (teste $t$ pareado) e o coeficiente de correlação de Pearson

\begin{tabular}{|c|c|c|c|c|c|c|c|}
\hline \multirow{2}{*}{ Variável } & \multicolumn{2}{|c|}{$1^{a}$ Medição } & \multicolumn{2}{|c|}{$2^{a}$ Medição } & \multirow{2}{*}{$\begin{array}{l}\text { Erro Casual } \\
\text { (Dahlberg) }\end{array}$} & \multirow{2}{*}{$\begin{array}{c}\text { Erro } \\
\text { Sistemático } \\
\mathbf{p}\end{array}$} & \multirow{2}{*}{\begin{tabular}{|c} 
Correlação \\
de \\
Pearson
\end{tabular}} \\
\hline & $\mathrm{X}$ & DP & $x$ & DP & & & \\
\hline \multicolumn{8}{|c|}{ Componente Maxilar } \\
\hline S.N.A & 80,30 & 3,58 & 80,95 & 4,22 & 1,559 & $0,046^{*}$ & 0,852 \\
\hline Co-A & 89,38 & 4,79 & 90,01 & 4,97 & 1,130 & $0,006^{*}$ & 0,953 \\
\hline \multicolumn{8}{|c|}{ Componente Mandibular } \\
\hline S.N.B & 76,60 & 3,44 & 76,83 & 3,72 & 1,205 & 0,369 & 0,886 \\
\hline Co-Gn & 111,95 & 5,47 & 112,57 & 5,66 & 1,109 & $0,006^{*}$ & 0,965 \\
\hline \multicolumn{8}{|c|}{ Relação Maxilomandibular } \\
\hline A.N.B & 3,70 & 1,65 & 4,11 & 1,73 & 0,618 & $0,001^{*}$ & 0,895 \\
\hline N.A.Pog & 5,15 & 3,65 & 6,10 & 3,79 & 1,309 & $0,000^{*}$ & 0,906 \\
\hline \multicolumn{8}{|c|}{ Componente Vertical } \\
\hline PoOr.PP & 1,27 & 3,17 & 1,60 & 2,85 & 1,050 & 0,141 & 0,881 \\
\hline PoOr.GoMe & 22,29 & 4,34 & 22,42 & 4,58 & 0,703 & 0,387 & 0,975 \\
\hline PoOr.PO & 8,01 & 3,79 & 7,98 & 3,75 & 1,063 & 0,877 & 0,918 \\
\hline ENA-Me & 63,16 & 3,96 & 63,49 & 4,13 & 0,852 & 0,064 & 0,958 \\
\hline $\mathrm{N}-\mathrm{Me}$ & 114,46 & 6,60 & 113,98 & 6,72 & 1,370 & 0,088 & 0,959 \\
\hline S-Go & 73,82 & 5,51 & 73,86 & 5,73 & 0,808 & 0,809 & 0,979 \\
\hline \multicolumn{8}{|c|}{ Componente Dento-alveolar Superior } \\
\hline 1.NA & 19,40 & 6,20 & 18,93 & 6,06 & 1,379 & 0,105 & 0.951 \\
\hline$\overline{1}-\mathrm{NA}$ & 3,25 & 2,42 & 2,75 & 1,97 & 0,753 & $0,001^{*}$ & 0,907 \\
\hline 1.PP & 107,59 & 6,50 & 107,14 & 6,66 & 1,674 & 0,198 & 0,936 \\
\hline$\overline{1}-\mathrm{PP}$ & 27,65 & 1,90 & 28,03 & 2,11 & 0,925 & $0,049^{*}$ & 0,802 \\
\hline 6.PP & 103,14 & 4,85 & 102,70 & 4,73 & 1,771 & 0,241 & 0,865 \\
\hline$\underline{6}-\mathrm{PP}$ & 20,19 & 2,17 & 20,53 & 2,24 & 0,685 & $0,017^{*}$ & 0,913 \\
\hline 1-SPerpPO & 81,22 & 4,82 & 81,13 & 4,74 & 0,701 & 0,568 & 0,978 \\
\hline 6-SPerpPO & 52,09 & 4,08 & 52,10 & 4,14 & 0,942 & 0,983 & 0,946 \\
\hline \multicolumn{8}{|c|}{ Componente Dento-alveolar Inferior } \\
\hline$\overline{1} . \mathrm{NB}$ & 23,38 & 5,18 & 23,94 & 5,61 & 1,528 & 0,079 & 0,923 \\
\hline$\overline{1}-\mathrm{NB}$ & 3,52 & 1,98 & 3,59 & 2,04 & 0,368 & 0,355 & 0,966 \\
\hline$\overline{1} . \mathrm{GoMe}$ & 95,32 & 5,79 & 95,82 & 6,18 & 1,575 & 0,126 & 0,933 \\
\hline$\overline{1}$-GoMe & 38,67 & 2,76 & 38,34 & 2,69 & 0,476 & $0,000^{*}$ & 0,976 \\
\hline$\overline{6}$. GoMe & 88,26 & 3,39 & 88,39 & 3,13 & 1,786 & 0,726 & 0,695 \\
\hline$\overline{6}$-GoMe & 28,68 & 2,11 & 28,45 & 2,18 & 0,525 & $0,030^{*}$ & 0,945 \\
\hline$\overline{1}$-SPerpPO & 76,59 & 4,29 & 76,52 & 4,27 & 0,752 & 0,652 & 0,968 \\
\hline$\overline{6}$-SPerpPO & 50,57 & 4,01 & 50,24 & 4,13 & 0,980 & 0,107 & 0,944 \\
\hline \multicolumn{8}{|c|}{ Relação Interdentária } \\
\hline Sobressaliência & 4,62 & 1,51 & 4,61 & 1,50 & 0,415 & 0,882 & 0,922 \\
\hline Relação Molar & $-0,16$ & 1,03 & 0,13 & 1,31 & 0,526 & $0,005^{*}$ & 0,830 \\
\hline \multicolumn{8}{|c|}{ Componente Tegumentar } \\
\hline Âng. Nasolabial & 117,36 & 9,10 & 118,82 & 12,16 & 8,176 & 0,397 & 0,417 \\
\hline Ls-PrnPog' & $-2,67$ & 1,98 & $-2,37$ & 2,38 & 0,959 & 0,141 & 0,814 \\
\hline Li-PrnPog' & $-1,68$ & 2,20 & $-1,36$ & 2,25 & 0,955 & 0,104 & 0,823 \\
\hline
\end{tabular}

* diferença estatisticamente significante $(p<0,05)$ 
Os erros casuais evidenciam o quanto cada medida cefalométrica pode variar durante a mensuração. Denota-se que apenas a medida do ângulo nasolabial, comparando-se com as variações recomendadas por Sandler ${ }^{173}$, apresenta um erro casual excedido. Isto é explicado pelo fato de que durante os traçados das telerradiografias pertencentes ao arquivo Burlington Growth Centre, Universidade de Toronto, verificou-se que os perfis moles, principalmente na região do nariz, apresentavam-se pouco nítidos, tornando a execução extremamente difícil. O arquivo explica esta deficiência pela utilização de pequenos chassis na época da obtenção das documentações ortodônticas.

Das 33 variáveis cafalométricas estudadas, 11 apresentaram um erro sistemático elucidado pelo teste estatístico t de Student ao nível de significância de $5 \%$. Contudo, observa-se que todos estes erros são pequenos se compararmos as diferenças médias entre as primeiras e as segundas medições, não excedendo a 1 grau ou a $1 \mathrm{~mm}$.

O coeficiente de correlação de Pearson, por sua vez, evidencia correlações extremamente aceitáveis entre as medições executadas.

Baseado nestas justificativas e levando em consideração a realização de 46 traçados cefalométricos como método estabelecido de análise do erro metodológico, julga-se aceitável e confiável o método de trabalho deste estudo, podendo dar continuidade às interpretações numéricas a seguir. 
TABELA 2 - Comparação intergrupos (Grupo 1 e Grupo Controle 1) na fase pré-tratamento, $\mathrm{T}_{1}$ (teste $\mathrm{t}$ )

\begin{tabular}{|c|c|c|c|c|c|}
\hline & \multicolumn{2}{|c|}{ Grupo 1} & \multicolumn{2}{|c|}{ Grupo Controle 1} & \multirow[t]{2}{*}{ p } \\
\hline Variável & $\mathrm{X}$ & D.P. & $\mathrm{X}$ & D.P. & \\
\hline \multicolumn{6}{|c|}{ Componente Maxilar } \\
\hline S.N.A & 82,05 & 3,57 & 81,40 & 4,75 & 0,603 \\
\hline Co-A & 91,37 & 6,08 & 89,55 & 4,26 & 0,263 \\
\hline \multicolumn{6}{|c|}{ Componente Mandibular } \\
\hline S.N.B & 76,50 & 2,96 & 77,39 & 4,42 & 0,424 \\
\hline Co-Gn & 112,87 & 6,07 & 111,86 & 4,85 & 0,548 \\
\hline \multicolumn{6}{|c|}{ Relação Maxilomandibular } \\
\hline A.N.B & 5,55 & 1,94 & 3,99 & 1,80 & $0,008^{*}$ \\
\hline N.A.Pog & 9,28 & 5,39 & 5,79 & 4,17 & $0,022^{*}$ \\
\hline \multicolumn{6}{|c|}{ Componente Vertical } \\
\hline PoOr.PP & 3,00 & 3,13 & 1,37 & 2,47 & 0,064 \\
\hline PoOr.GoMe & 22,05 & 5,10 & 22,09 & 4,63 & 0,978 \\
\hline PoOr.PO & 3,67 & 3,95 & 8,10 & 3,63 & $0,000^{*}$ \\
\hline ENA-Me & 66,28 & 4,66 & 63,20 & 3,83 & $0,022^{*}$ \\
\hline $\mathrm{N}-\mathrm{Me}$ & 116,20 & 7,26 & 112,98 & 6,40 & 0,127 \\
\hline S-Go & 75,08 & 6,23 & 74,23 & 4,08 & 0,602 \\
\hline \multicolumn{6}{|c|}{ Componente Dento-alveolar Superior } \\
\hline 1.NA & 27,77 & 8,44 & 19,00 & 5,62 & $0,000^{*}$ \\
\hline $1-N A$ & 5,60 & 2,85 & 2,72 & 1,96 & $0,000^{*}$ \\
\hline 1.PP & 116,56 & 7,18 & 107,08 & 6,25 & $0,000^{*}$ \\
\hline 1-PP & 28,07 & 2,17 & 28,21 & 1,78 & 0,817 \\
\hline 6.PP & 100,78 & 4,80 & 102,21 & 3,45 & 0,269 \\
\hline$\underline{6}-\mathrm{PP}$ & 21,70 & 1,88 & 20,82 & 1,89 & 0,127 \\
\hline 1-SPerpPO & 83,24 & 5,09 & 80,77 & 5,14 & 0,115 \\
\hline 6-SPerpPO & 50,83 & 4,23 & 51,88 & 3,96 & 0,399 \\
\hline \multicolumn{6}{|c|}{ Componente Dento-alveolar Inferior } \\
\hline 1.NB & 26,14 & 6,92 & 24,70 & 5,64 & 0,456 \\
\hline$\overline{1}-\mathrm{NB}$ & 4,73 & 2,37 & 3,63 & 2,03 & 0,107 \\
\hline 1.GoMe & 97,85 & 7,00 & 97,15 & 6,33 & 0,730 \\
\hline$\overline{1}$-GoMe & 40,84 & 3,47 & 37,86 & 2,37 & $0,002^{*}$ \\
\hline$\overline{6}$.GoMe & 85,54 & 3,68 & 88,58 & 3,42 & $0,007^{*}$ \\
\hline$\overline{6}-\mathrm{GoMe}$ & 28,95 & 2,65 & 28,06 & 2,24 & 0,238 \\
\hline$\overline{1}$-SPerpPO & 74,82 & 5,43 & 76,46 & 4,85 & 0,297 \\
\hline$\overline{6}$-SPerpPO & 48,48 & 4,38 & 49,92 & 3,85 & 0,254 \\
\hline \multicolumn{6}{|c|}{ Relação Interdentária } \\
\hline Sobressaliência & 8,42 & 2,22 & 4,30 & 1,55 & $0,000^{*}$ \\
\hline Relação Molar & 1,06 & 1,04 & 0,36 & 1,30 & 0,051 \\
\hline \multicolumn{6}{|c|}{ Componente Tegumentar } \\
\hline Âng. Nasolabial & 111,09 & 8,97 & 116,65 & 13,17 & 0,100 \\
\hline Ls-PrnPog' & $-0,77$ & 2,10 & $-2,55$ & 2,27 & $0,009^{*}$ \\
\hline Li-PrnPog' & 0,34 & 2,22 & $-1,57$ & 2,36 & $0,008^{*}$ \\
\hline
\end{tabular}

* diferença estatisticamente significante $(p<0,05)$ 

pareado)

TABELA 3 - Alterações do tratamento com o aparelho de Herbst (teste $t$

\begin{tabular}{|c|c|c|c|c|c|}
\hline & \multicolumn{2}{|c|}{$\mathrm{T}_{1}$} & \multicolumn{2}{|c|}{$\mathbf{T}_{2}$} & \multirow[t]{2}{*}{$\mathbf{p}$} \\
\hline Variável & $\mathrm{X}$ & D.P. & $\mathrm{X}$ & D.P. & \\
\hline \multicolumn{6}{|c|}{ Componente Maxilar } \\
\hline S.N.A & 82,05 & 3,57 & 82,13 & 3,80 & 0,872 \\
\hline Co-A & 91,37 & 6,08 & 93,42 & 6,14 & $0,001^{*}$ \\
\hline \multicolumn{6}{|c|}{ Componente Mandibular } \\
\hline S.N.B & 76,50 & 2,96 & 77,93 & 2,67 & $0,000^{*}$ \\
\hline Co-Gn & 112,87 & 6,07 & 118,23 & 5,94 & $0,000^{*}$ \\
\hline \multicolumn{6}{|c|}{ Relação Maxilomandibular } \\
\hline A.N.B & 5,55 & 1,94 & 4,18 & 2,13 & $0,000^{*}$ \\
\hline N.A.Pog & 9,28 & 5,39 & 6,62 & 5,47 & $0,000^{*}$ \\
\hline \multicolumn{6}{|c|}{ Componente Vertical } \\
\hline PoOr.PP & 3,00 & 3,13 & 1,80 & 2,92 & $0,003^{*}$ \\
\hline PoOr.GoMe & 22,05 & 5,10 & 21,84 & 5,15 & 0,579 \\
\hline PoOr.PO & 3,67 & 3,95 & 6,57 & 4,04 & $0,000^{*}$ \\
\hline ENA-Me & 66,28 & 4,66 & 68,31 & 4,65 & $0,000^{*}$ \\
\hline $\mathrm{N}-\mathrm{Me}$ & 116,20 & 7,26 & 120,11 & 7,39 & $0,000^{*}$ \\
\hline S-Go & 75,08 & 6,23 & 79,15 & 6,83 & $0,000^{*}$ \\
\hline \multicolumn{6}{|c|}{ Componente Dento-alveolar Superior } \\
\hline 1.NA & 27,77 & 8,44 & 23,90 & 7,75 & $0,009^{*}$ \\
\hline 1-NA & 5,60 & 2,85 & 4,34 & 3,08 & $0,016^{*}$ \\
\hline 1.PP & 116,56 & 7,18 & 113,12 & 7,10 & $0,016^{*}$ \\
\hline 1-PP & 28,07 & 2,17 & 29,26 & 2,44 & $0,000^{*}$ \\
\hline 6.PP & 100,78 & 4,80 & 105,21 & 4,90 & $0,000^{*}$ \\
\hline$\underline{6}-\mathrm{PP}$ & 21,70 & 1,88 & 22,19 & 1,88 & $0,038^{*}$ \\
\hline 1-SPerpPO & 83,24 & 5,09 & 85,40 & 5,42 & $0,000^{*}$ \\
\hline 6-SPerpPO & 50,83 & 4,23 & 52,52 & 4,85 & $0,001^{*}$ \\
\hline \multicolumn{6}{|c|}{ Componente Dento-alveolar Inferior } \\
\hline 1.NB & 26,14 & 6,92 & 33,69 & 6,07 & $0,000^{*}$ \\
\hline$\overline{1}-\mathrm{NB}$ & 4,73 & 2,37 & 6,91 & 1,96 & $0,000^{*}$ \\
\hline 1.GoMe & 97,85 & 7,00 & 104,99 & 7,77 & $0,000^{*}$ \\
\hline 1-GoMe & 40,84 & 3,47 & 40,18 & 3,20 & $0,020^{*}$ \\
\hline$\overline{6}$.GoMe & 85,54 & 3,68 & 88,62 & 3,97 & $0,000^{*}$ \\
\hline$\overline{6}$-GoMe & 28,95 & 2,65 & 30,20 & 3,06 & $0,000^{*}$ \\
\hline 1-SPerpPO & 74,82 & 5,43 & 81,94 & 5,63 & $0,000^{*}$ \\
\hline$\overline{6}$-SPerpPO & 48,48 & 4,38 & 55,38 & 4,32 & $0,000^{*}$ \\
\hline \multicolumn{6}{|c|}{ Relação Interdentária } \\
\hline Sobressaliência & 8,42 & 2,22 & 3,46 & 1,15 & $0,000^{*}$ \\
\hline Relação Molar & 1,06 & 1,04 & $-4,42$ & 1,85 & $0,000^{*}$ \\
\hline \multicolumn{6}{|c|}{ Componente Tegumentar } \\
\hline Âng. Nasolabial & 111,09 & 8,97 & 111,59 & 9,24 & 0,713 \\
\hline Ls-PrnPog' & $-0,77$ & 2,10 & $-2,59$ & 2,16 & $0,000^{*}$ \\
\hline Li-PrnPog' & 0,34 & 2,22 & 0,79 & 2,30 & 0,051 \\
\hline
\end{tabular}

* diferença estatisticamente significante $(p<0,05)$ 
TABELA 4 - Alterações normais com o crescimento no Grupo Controle 1, em período de tempo compatível com o Grupo 1 (teste t pareado)

\begin{tabular}{|c|c|c|c|c|c|}
\hline & \multicolumn{2}{|c|}{$T_{1}$} & \multicolumn{2}{|c|}{$\mathrm{T}_{2}$} & \multirow[t]{2}{*}{$\mathbf{p}$} \\
\hline Variável & $\mathrm{X}$ & D.P. & $\mathrm{X}$ & D.P. & \\
\hline \multicolumn{6}{|c|}{ Componente Maxilar } \\
\hline S.N.A & 81,40 & 4,75 & 81,39 & 4,29 & 0,981 \\
\hline Co-A & 89,55 & 4,26 & 92,94 & 4,76 & $0,000^{*}$ \\
\hline \multicolumn{6}{|c|}{ Componente Mandibular } \\
\hline S.N.B & 77,39 & 4,42 & 77,57 & 3,88 & 0,634 \\
\hline Co-Gn & 111,86 & 4,85 & 117,02 & 5,06 & $0,000^{*}$ \\
\hline \multicolumn{6}{|c|}{ Relação Maxilomandibular } \\
\hline A.N.B & 3,99 & 1,80 & 3,81 & 1,60 & 0,445 \\
\hline N.A.Pog & 5,79 & 4,17 & 4,73 & 4,26 & 0,052 \\
\hline \multicolumn{6}{|c|}{ Componente Vertical } \\
\hline PoOr.PP & 1,37 & 2,47 & 1,08 & 2,70 & 0,545 \\
\hline PoOr.GoMe & 22,09 & 4,63 & 21,03 & 4,08 & 0,071 \\
\hline PoOr.PO & 8,10 & 3,63 & 5,93 & 3,71 & $0,000^{*}$ \\
\hline ENA-Me & 63,20 & 3,83 & 65,58 & 3,58 & $0,000^{*}$ \\
\hline $\mathrm{N}-\mathrm{Me}$ & 112,98 & 6,40 & 118,29 & 5,79 & $0,000^{*}$ \\
\hline S-Go & 74,23 & 4,08 & 78,61 & 5,05 & $0,000^{*}$ \\
\hline \multicolumn{6}{|c|}{ Componente Dento-alveolar Superior } \\
\hline 1.NA & 19,00 & 5,62 & 19,01 & 5,92 & 0,996 \\
\hline$\overline{1-N A}$ & 2,72 & 1,96 & 2,87 & 2,21 & 0,605 \\
\hline 1.PP & 107,08 & 6,25 & 107,46 & 7,28 & 0,733 \\
\hline 1-PP & 28,21 & 1,78 & 29,91 & 2,12 & $0,019^{*}$ \\
\hline 6.PP & 102,21 & 3,45 & 99,87 & 3,68 & $0,001^{*}$ \\
\hline$\underline{6}-\mathrm{PP}$ & 20,82 & 1,89 & 22,74 & 1,71 & $0,000^{*}$ \\
\hline 1-SPerpPO & 80,77 & 5,14 & 81,92 & 6,23 & 0,061 \\
\hline 6-SPerpPO & 51,88 & 3,96 & 53,38 & 4,75 & $0,001^{*}$ \\
\hline \multicolumn{6}{|c|}{ Componente Dento-alveolar Inferior } \\
\hline 1.NB & 24,70 & 5,64 & 23,12 & 5,45 & $0,019^{*}$ \\
\hline$\overline{1}-\mathrm{NB}$ & 3,63 & 2,03 & 3,40 & 1,95 & 0,261 \\
\hline$\overline{1}$ 1.GoMe & 97,15 & 6,33 & 96,36 & 6,11 & 0,294 \\
\hline$\overline{1}$-GoMe & 37,86 & 2,37 & 39,81 & 2,20 & $0,000^{*}$ \\
\hline$\overline{6}$.GoMe & 88,58 & 3,42 & 88,40 & 3,72 & 0,849 \\
\hline$\overline{6}$-GoMe & 28,06 & 2,24 & 29,25 & 2,26 & $0,000^{*}$ \\
\hline 1-SPerpPO & 76,46 & 4,85 & 77,27 & 5,45 & 0,110 \\
\hline$\overline{6}$-SPerpPO & 49,92 & 3,85 & 51,67 & 4,88 & $0,002^{*}$ \\
\hline \multicolumn{6}{|c|}{ Relação Interdentária } \\
\hline Sobressaliência & 4,30 & 1,55 & 4,65 & 1,65 & 0,121 \\
\hline Relação Molar & 0,36 & 1,30 & 0,12 & 1,37 & 0,524 \\
\hline \multicolumn{6}{|c|}{ Componente Tegumentar } \\
\hline Âng. Nasolabial & 116,65 & 13,17 & 116,04 & 15,11 & 0,838 \\
\hline Ls-PrnPog' & $-2,55$ & 2,27 & $-3,22$ & 2,40 & 0,174 \\
\hline Li-PrnPog' & $-1,57$ & 2,36 & $-2,23$ & 2,22 & 0,173 \\
\hline
\end{tabular}

* diferença estatisticamente significante $(p<0,05)$ 
TABELA 5 - Comparação entre as alterações do tratamento com o aparelho de Herbst e as alterações do Grupo Controle 1 (teste $t$ )

\begin{tabular}{|c|c|c|c|c|c|}
\hline & \multicolumn{2}{|c|}{ Grupo 1} & \multicolumn{2}{|c|}{ Grupo Controle 1} & \multirow[t]{2}{*}{ p } \\
\hline Variável & $\mathrm{X}$ & D.P. & $\mathrm{X}$ & D.P. & \\
\hline \multicolumn{6}{|c|}{ Componente Maxilar } \\
\hline S.N.A & 0,07 & 2,33 & $-0,01$ & 1,89 & 0,902 \\
\hline Co-A & 2,04 & 2,71 & 3,38 & 2,14 & 0,078 \\
\hline \multicolumn{6}{|c|}{ Componente Mandibular } \\
\hline S.N.B & 1,42 & 1,76 & 0,18 & 1,66 & $0,020^{*}$ \\
\hline Co-Gn & 5,35 & 2,24 & 5,16 & 2,99 & 0,809 \\
\hline \multicolumn{6}{|c|}{ Relação Maxilomandibular } \\
\hline A.N.B & $-1,36$ & 1,57 & $-0,17$ & 1,00 & $0,005^{*}$ \\
\hline N.A.Pog & $-2,66$ & 3,20 & $-1,06$ & 2,29 & 0,067 \\
\hline \multicolumn{6}{|c|}{ Componente Vertical } \\
\hline PoOr.PP & $-1,19$ & 1,82 & $-0,28$ & 2,06 & 0,123 \\
\hline PoOr.GoMe & $-0,21$ & 1,88 & $-1,06$ & 2,47 & 0,197 \\
\hline PoOr.PO & 2,90 & 2,64 & $-2,17$ & 2,00 & $0,000^{*}$ \\
\hline ENA-Me & 2,02 & 1,67 & 2,38 & 2,13 & 0,528 \\
\hline $\mathrm{N}-\mathrm{Me}$ & 3,90 & 2,39 & 5,31 & 3,36 & 0,108 \\
\hline S-Go & 4,07 & 2,37 & 4,37 & 2,56 & 0,686 \\
\hline \multicolumn{6}{|c|}{ Componente Dento-alveolar Superior } \\
\hline 1.NA & $-3,87$ & 6,80 & 0,00 & 4,48 & $0,034^{*}$ \\
\hline$\overline{1-N A}$ & $-1,25$ & 2,42 & 0,15 & 1,27 & $0,024^{*}$ \\
\hline$\overline{1} . \mathrm{PP}$ & $-3,43$ & 6,59 & 0,37 & 4,84 & $0,037^{*}$ \\
\hline 1-PP & 1,19 & 1,41 & 0,70 & 1,23 & 0,227 \\
\hline 6.PP & 4,42 & 3,41 & $-2,34$ & 2,58 & $0,000^{*}$ \\
\hline 6-PP & 0,48 & 1,09 & 1,91 & 1,00 & $0,000^{*}$ \\
\hline 1-SPerpPO & 2,15 & 1,54 & 1,15 & 2,59 & 0,115 \\
\hline 6-SPerpPO & 1,68 & 2,26 & 1,49 & 1,62 & 0,753 \\
\hline \multicolumn{6}{|c|}{ Componente Dento-alveolar Inferior } \\
\hline 1.NB & 7,55 & 3,75 & $-1,58$ & 2,77 & $0,000^{*}$ \\
\hline$\overline{1}-\mathrm{NB}$ & 2,18 & 1,08 & $-0,23$ & 0,90 & $0,000^{*}$ \\
\hline$\overline{1} . \mathrm{GoMe}$ & 7,14 & 3,57 & $-0,79$ & 3,29 & $0,000^{*}$ \\
\hline$\overline{1}-$ GoMe & $-0,66$ & 1,32 & 1,94 & 1,24 & $0,000^{*}$ \\
\hline$\overline{6}$.GoMe & 3,08 & 2,48 & $-0,17$ & 4,05 & $0,002^{*}$ \\
\hline$\overline{6}$-GoMe & 1,25 & 1,17 & 1,18 & 1,26 & 0,848 \\
\hline$\overline{1}$-SPerpPO & 7,12 & 2,51 & 0,80 & 2,14 & $0,000^{*}$ \\
\hline$\overline{6}$-SPerpPO & 6,89 & 2,39 & 1,74 & 2,24 & $0,000^{*}$ \\
\hline \multicolumn{6}{|c|}{ Relação Interdentária } \\
\hline Sobressaliência & $-4,96$ & 1,86 & 0,35 & 0,96 & $0,000^{*}$ \\
\hline Relação Molar & $-5,48$ & 1,67 & $-0,23$ & 1,61 & $0,000^{*}$ \\
\hline \multicolumn{6}{|c|}{ Componente Tegumentar } \\
\hline Âng. Nasolabial & 0,49 & 6,66 & $-0,61$ & 13,17 & 0,718 \\
\hline Ls-PrnPog' & $-1,82$ & 1,47 & $-0,67$ & 2,11 & $0,037^{*}$ \\
\hline Li-PrnPog' & 0,45 & 1,10 & $-0,66$ & 2,08 & $0,026^{*}$ \\
\hline
\end{tabular}

* diferença estatisticamente significante $(p<0,05)$ 


\section{REPRESENTAÇÕES GRÁFICAS}

\section{Grupo 1 x Grupo Controle 1}

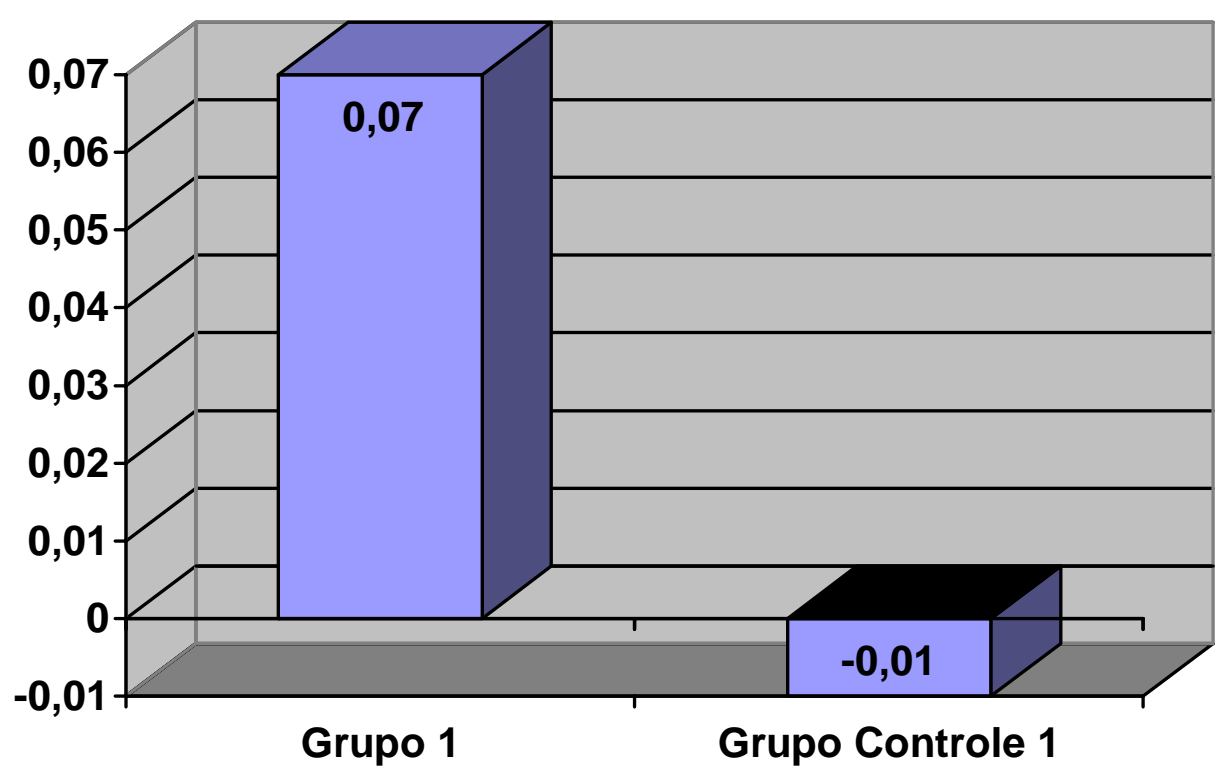

$\square$ S.N.A

FIGURA 10 - Componente Maxilar $\left(^{\circ}\right)$ - S.N.A

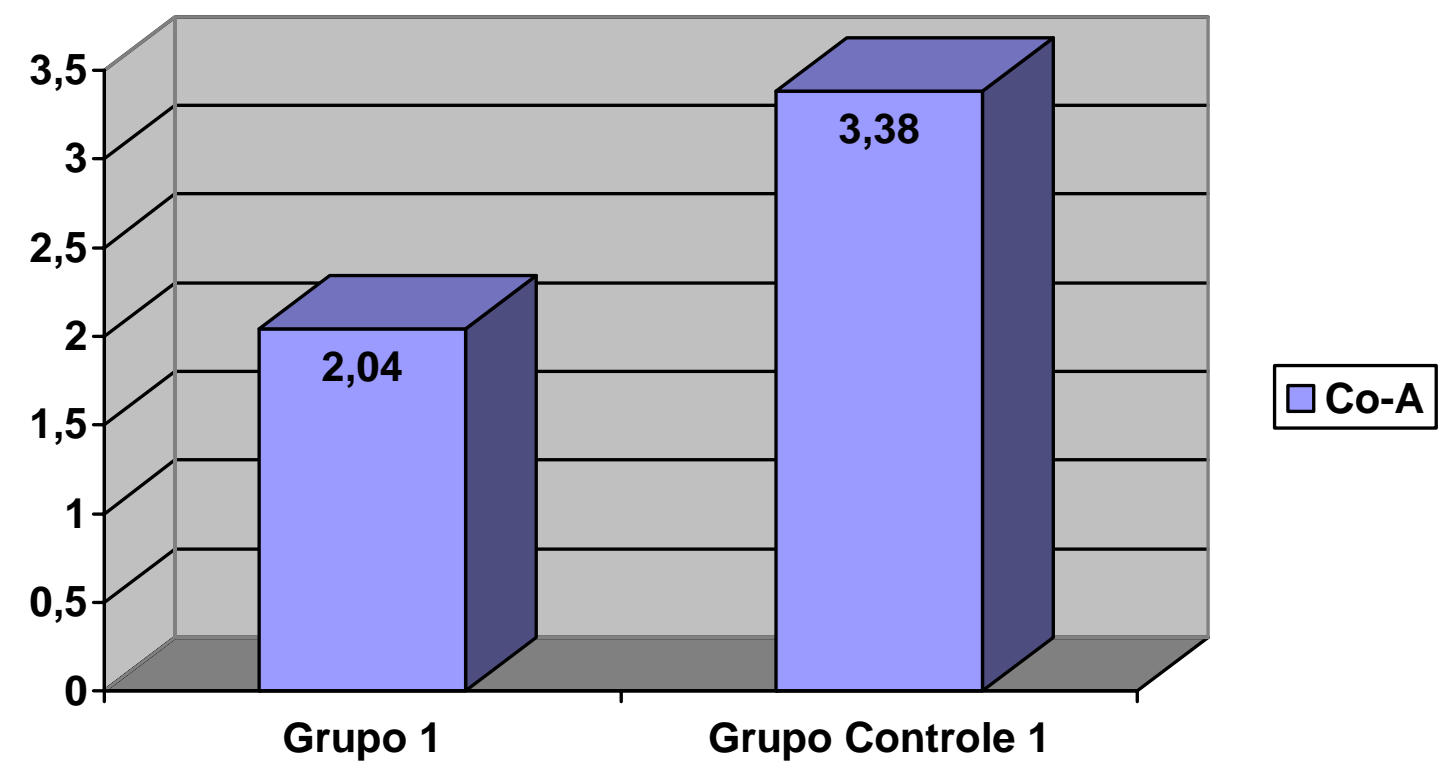

FIGURA 11 - Componente Maxilar (mm) - Co-A 


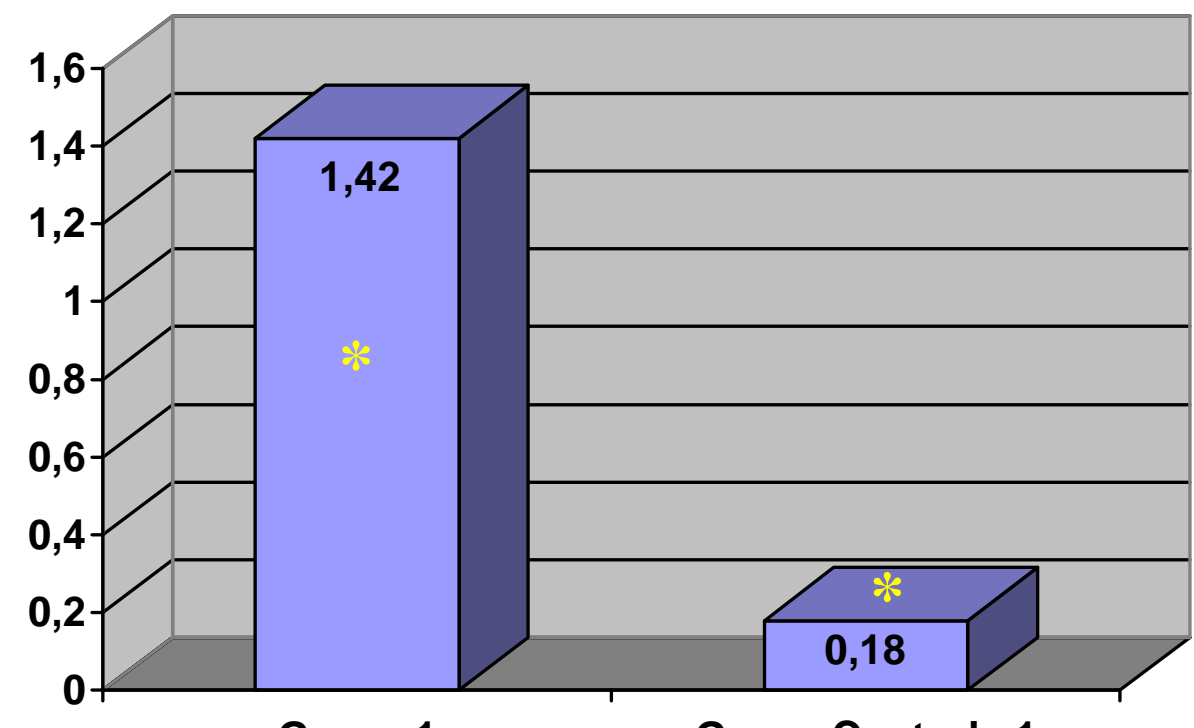

$\square$ S.N.B

Grupo 1

Grupo Controle 1

FIGURA 12 - Componente Mandibular $\left({ }^{\circ}\right)$ - S.N.B

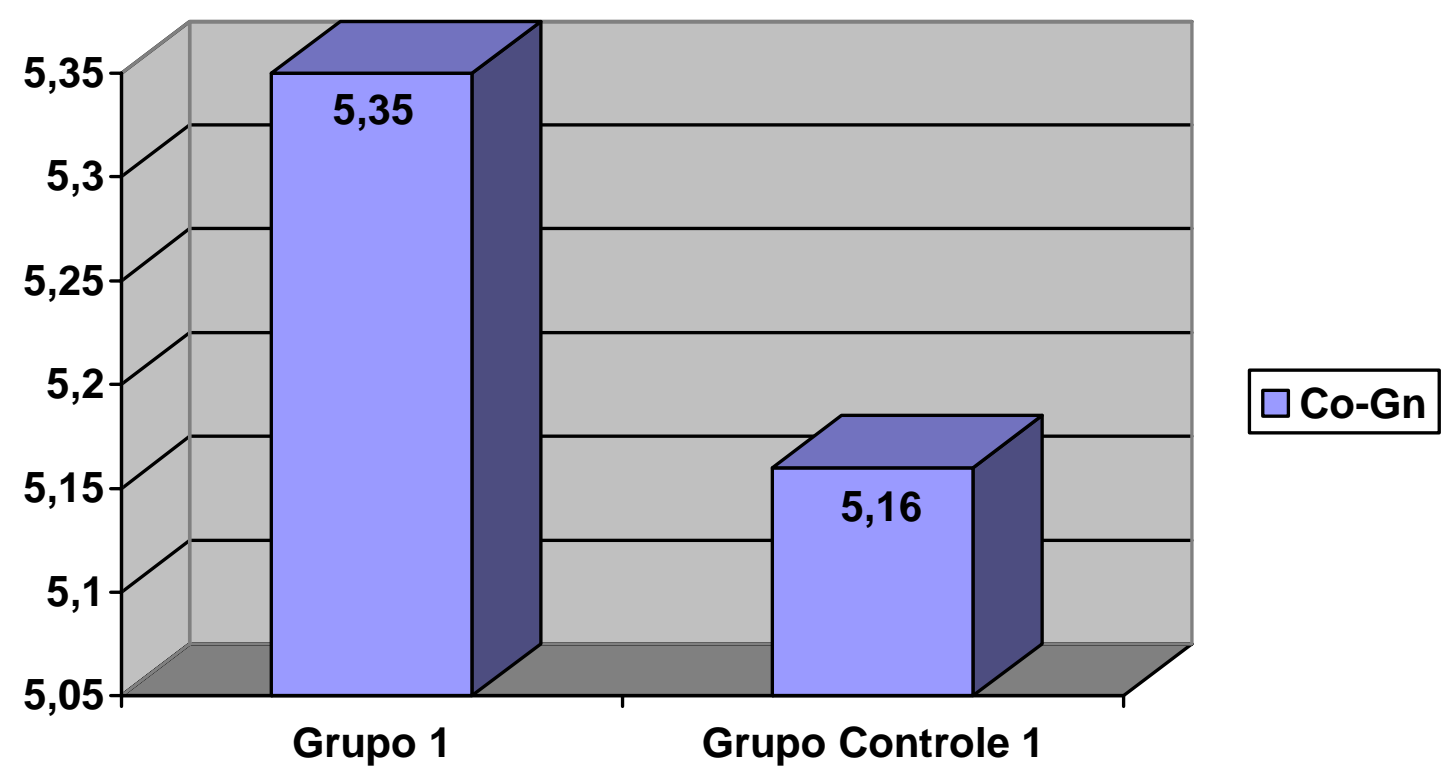

FIGURA 13 - Componente Mandibular (mm) - Co-Gn 


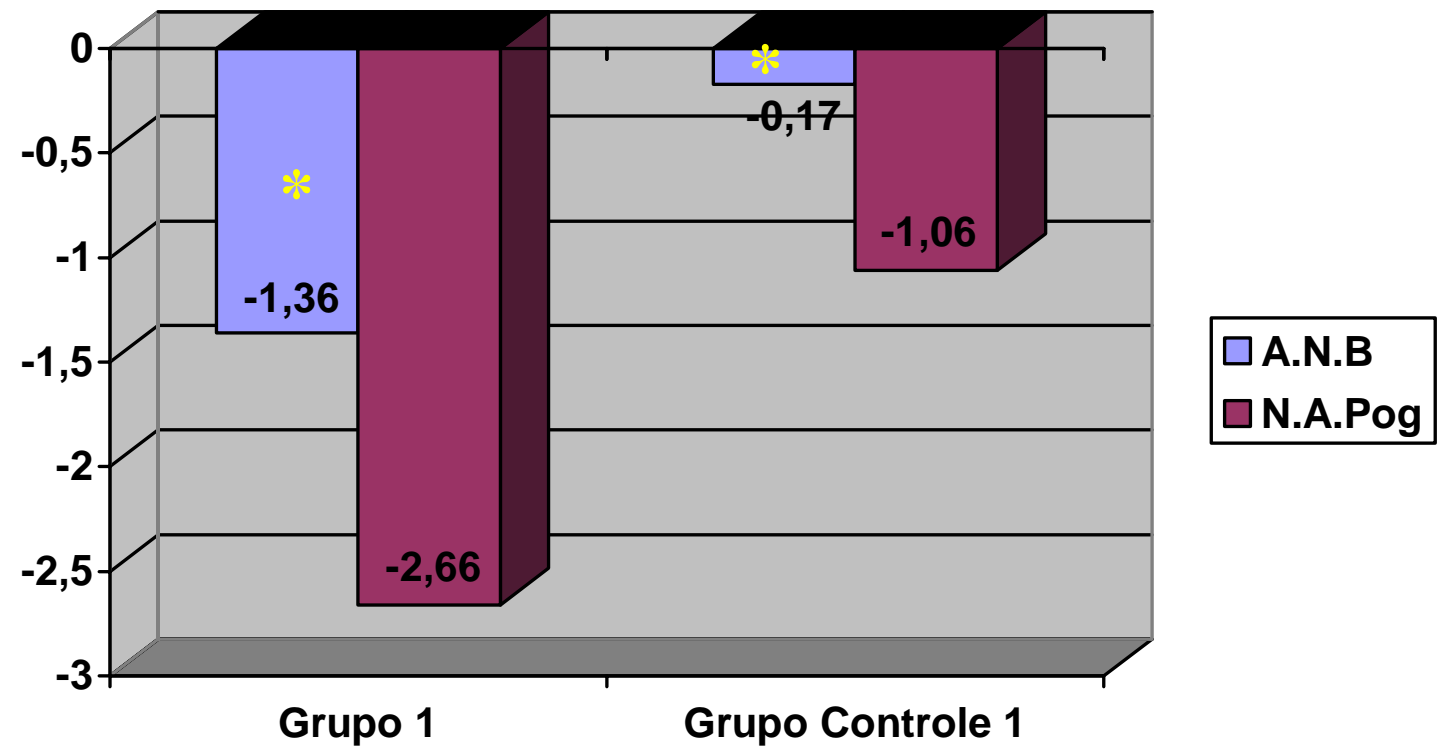

FIGURA 14 - Relação Maxilomandibular $\left({ }^{\circ}\right)$ - A.N.B; N.A.Pog
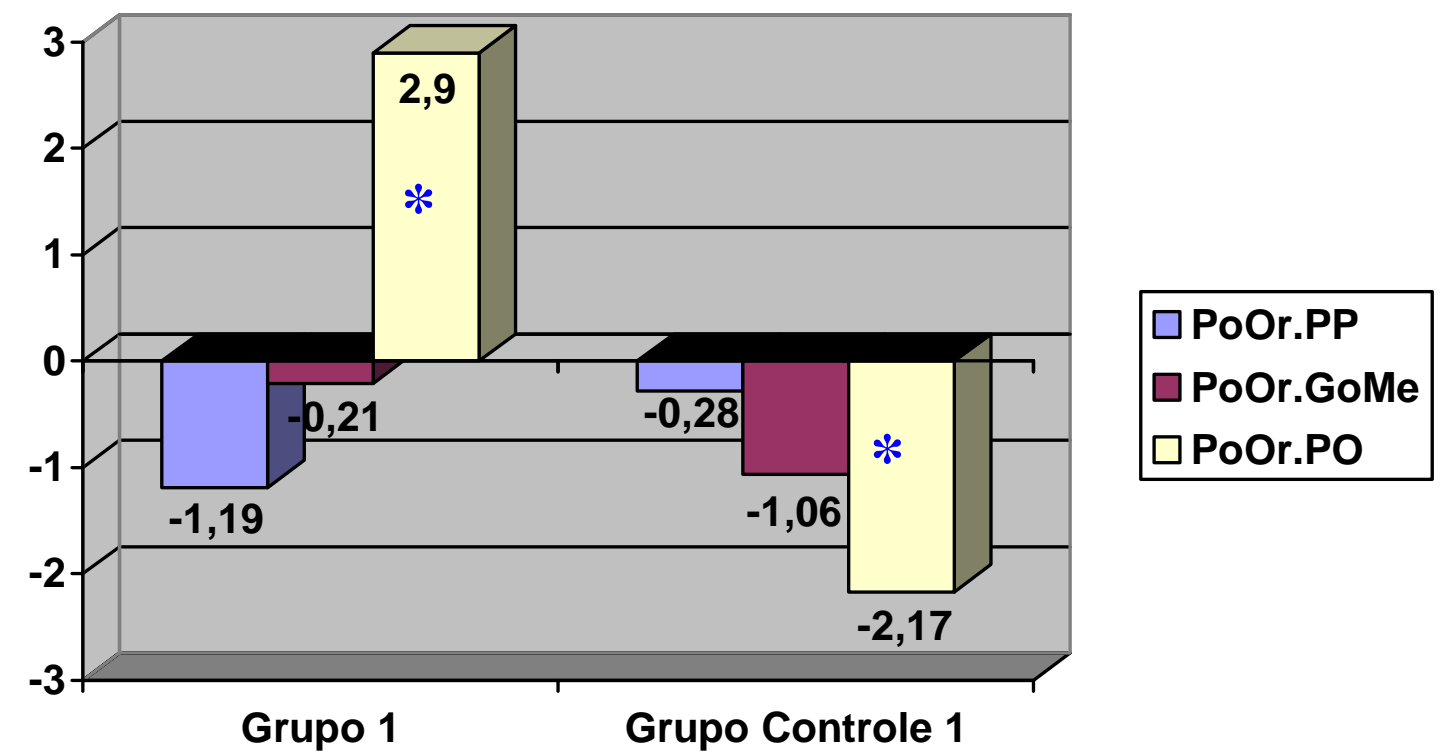

FIGURA 15 - Componente Vertical $\left({ }^{\circ}\right)$ - PoOr.PP; PoOr.GoMe; PoOr.PO 

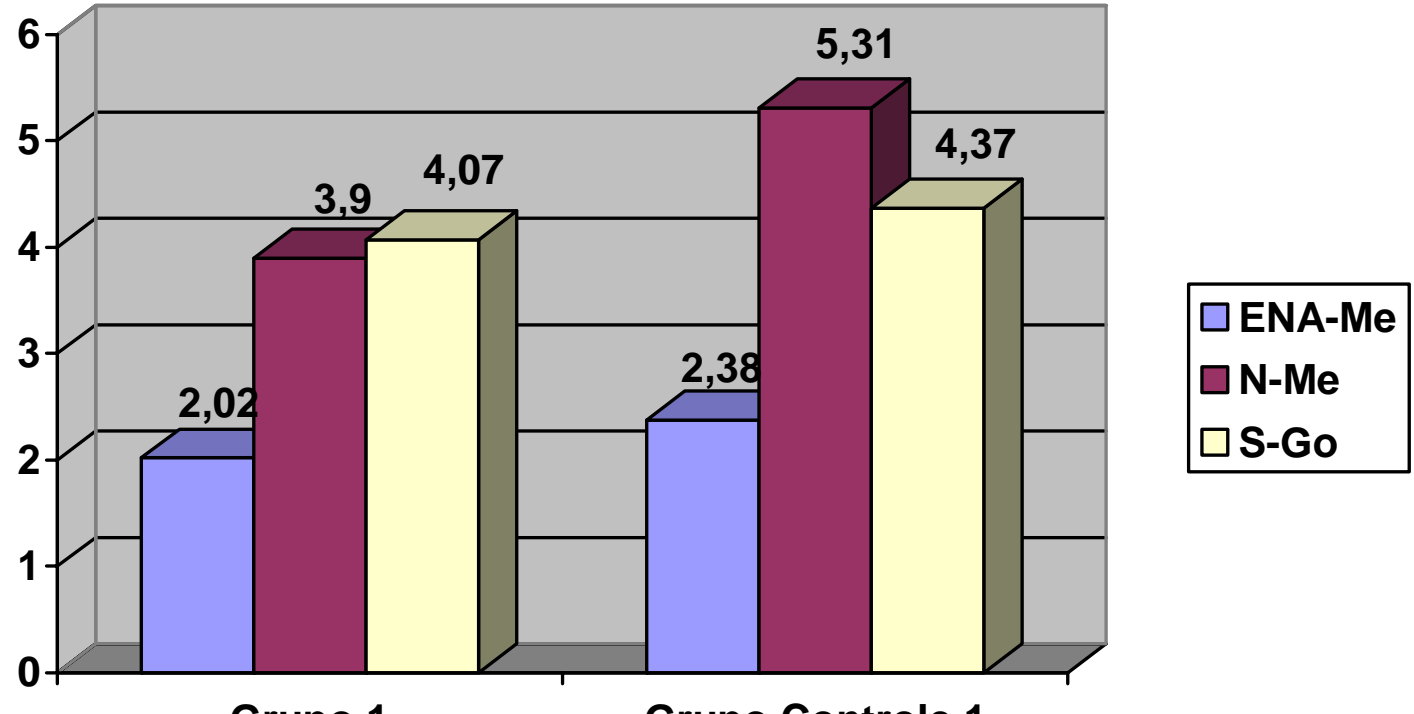

Grupo 1

Grupo Controle 1

FIGURA 16 - Componente Vertical (mm) - ENA-Me; N-Me; S-Go

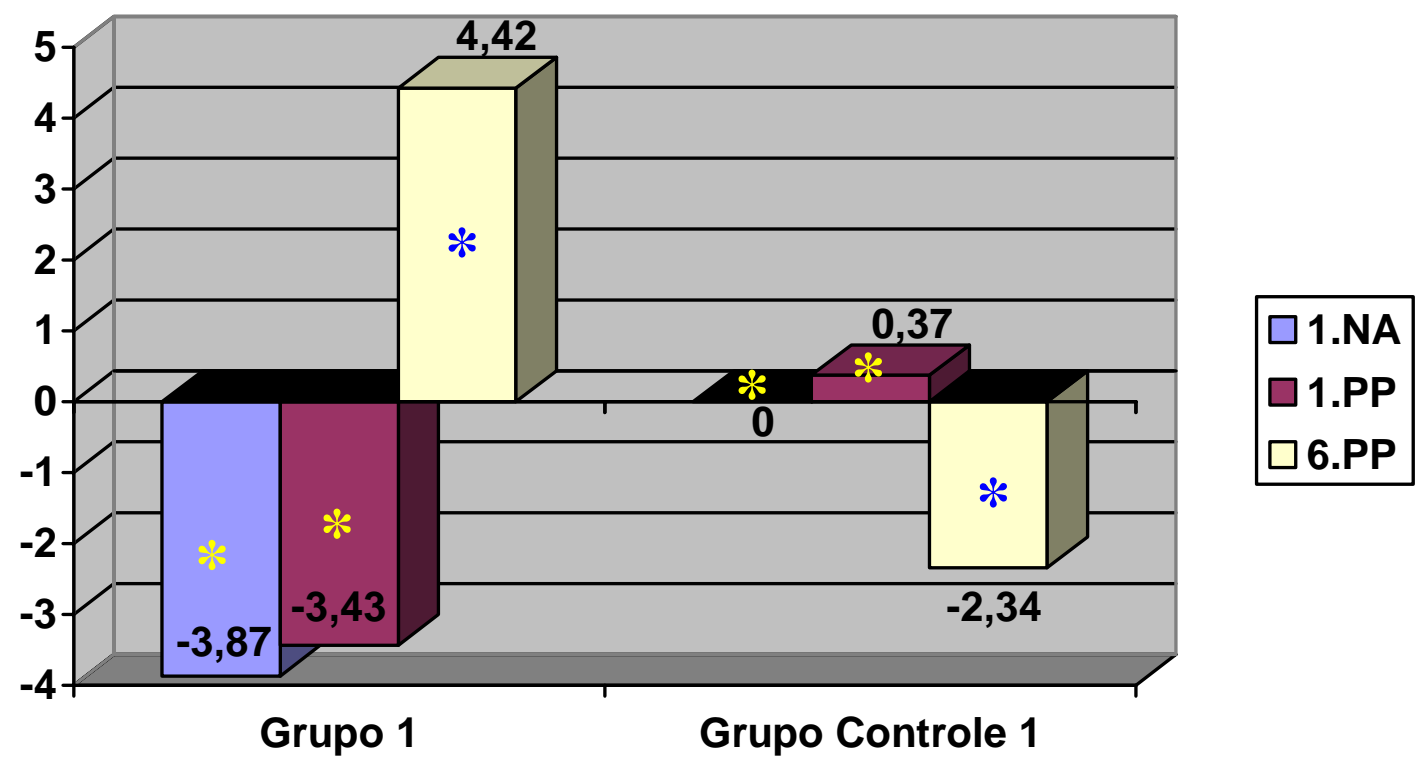

FIGURA 17 - Componente Dento-alveolar Superior $\left({ }^{\circ}\right)$ - $\underline{1} . N A ; \underline{1} . P P ; \underline{6} . P P$ 


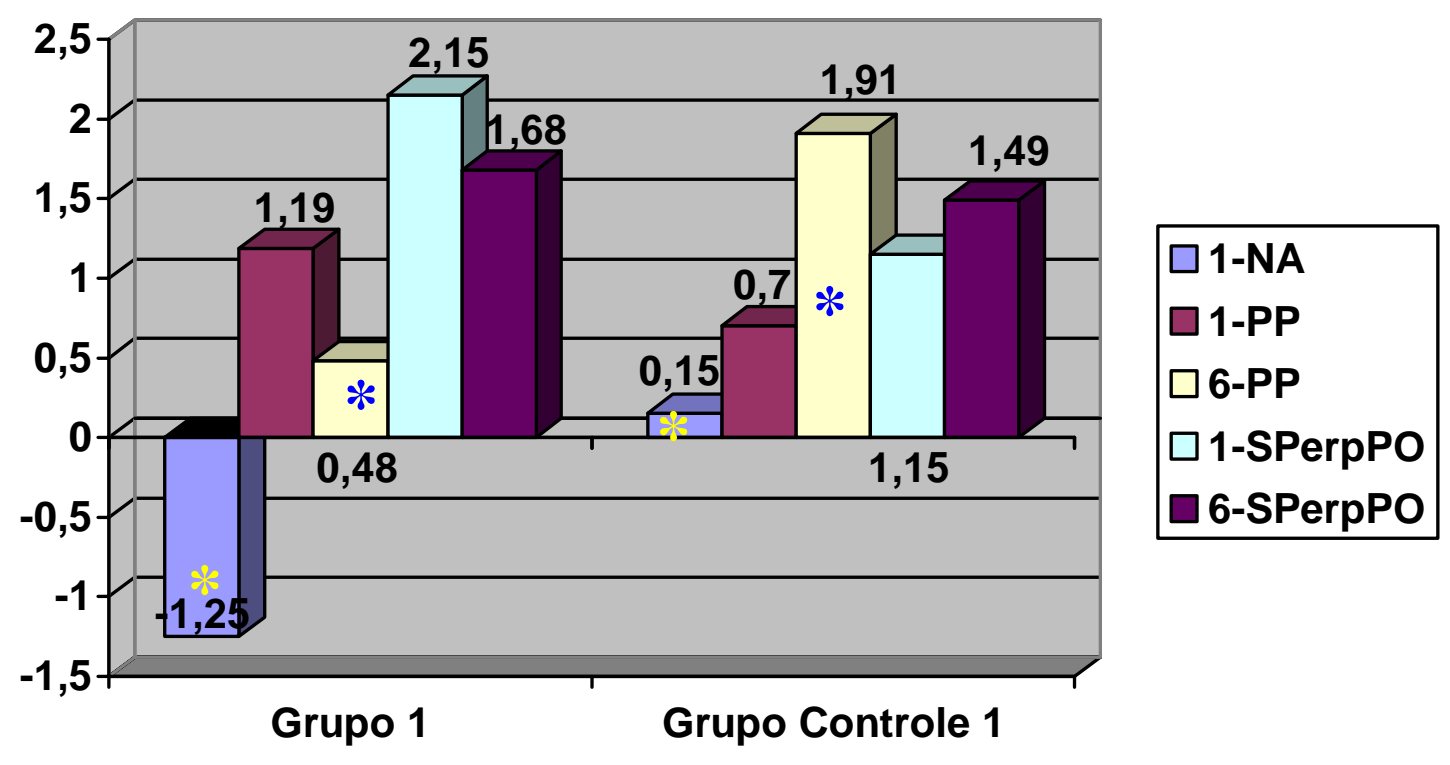

FIGURA 18 - Componente Dento-alveolar Superior (mm) - $\underline{1}-N A ; \underline{1}-P P ; \underline{6}-P P$; 1-SPerpPO; $\underline{6}$-SPerpPO

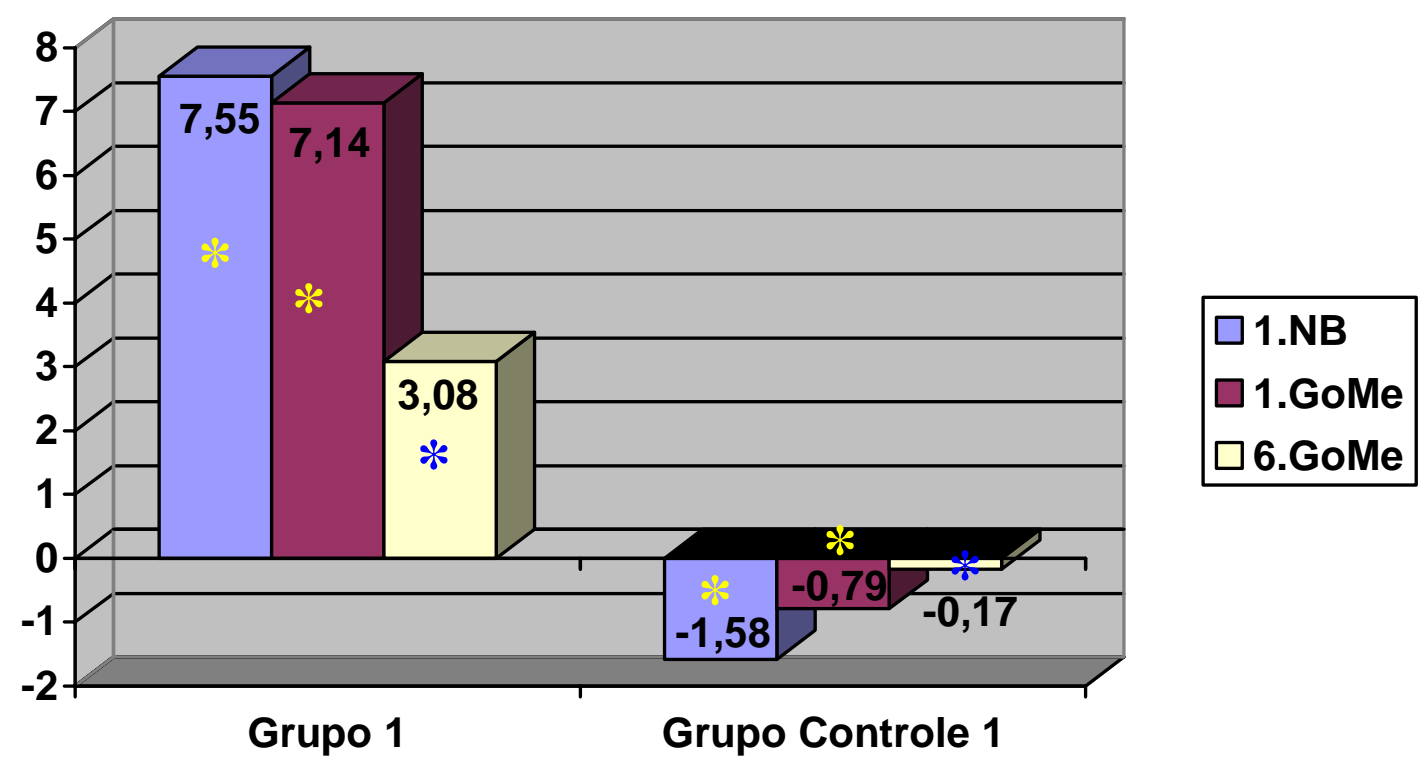

FIGURA 19 - Componente Dento-alveolar Inferior $\left({ }^{\circ}\right)-\overline{1} . N B ; \overline{1} . G o M e ; \overline{6} . G o M e$ 


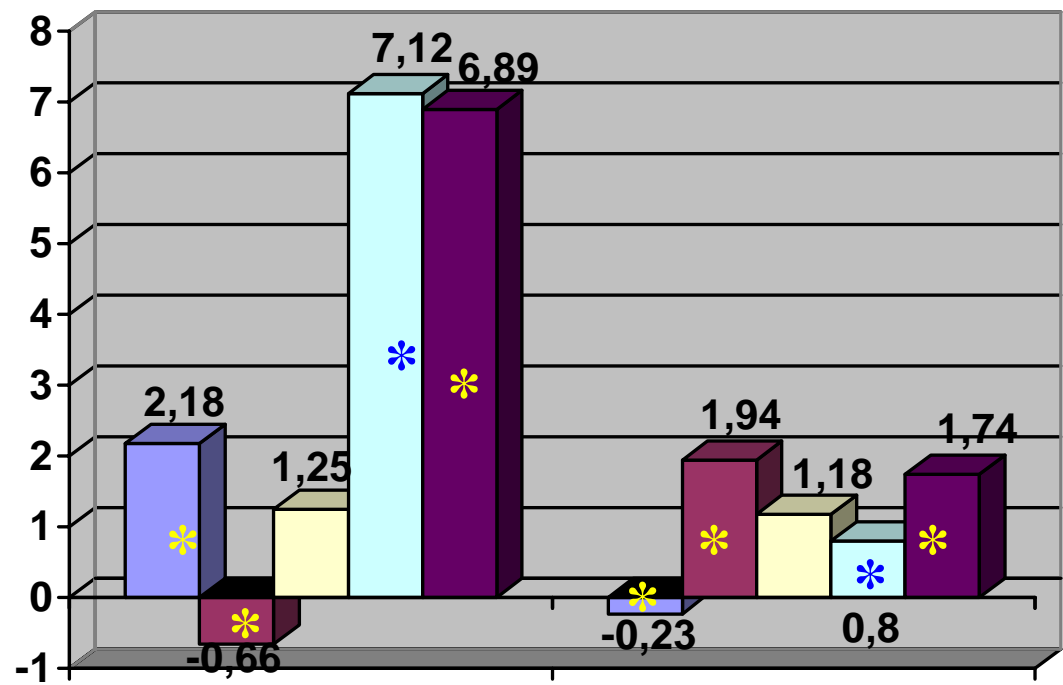

Grupo 1
Grupo Controle 1

\begin{tabular}{|l|}
\hline$\square$ 1-NB \\
$\square$ 1-GoMe \\
$\square$ 6-GoMe \\
$\square$ 1-SPerpPo \\
$\square$ 6-SPerpPo \\
\hline
\end{tabular}

FIGURA 20 - Componente Dento-alveolar Inferior (mm) - $\overline{1}-N B ; \overline{1}$-GoMe; $\overline{6}$-GoMe; $\overline{1}$-SPerpPO; $\overline{6}$-SPerpPO

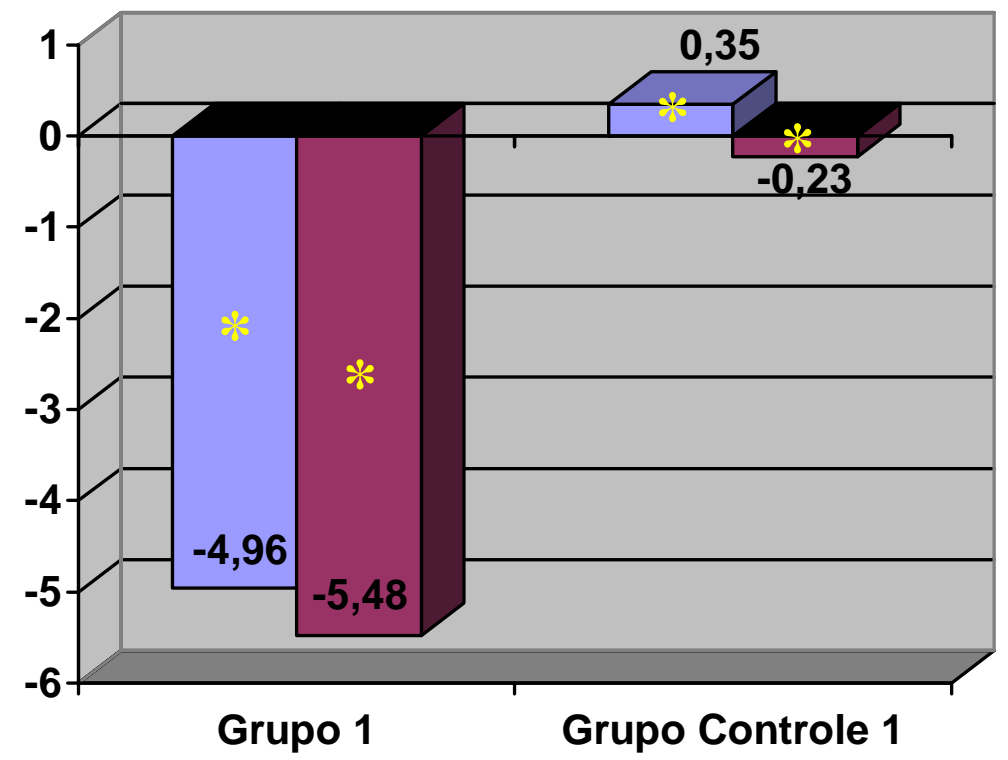

$\square$ Sobressaliência $\square$ Relação Molar

FIGURA 21 - Relação Interdentária (mm) - Sobressaliência; Relação Molar 


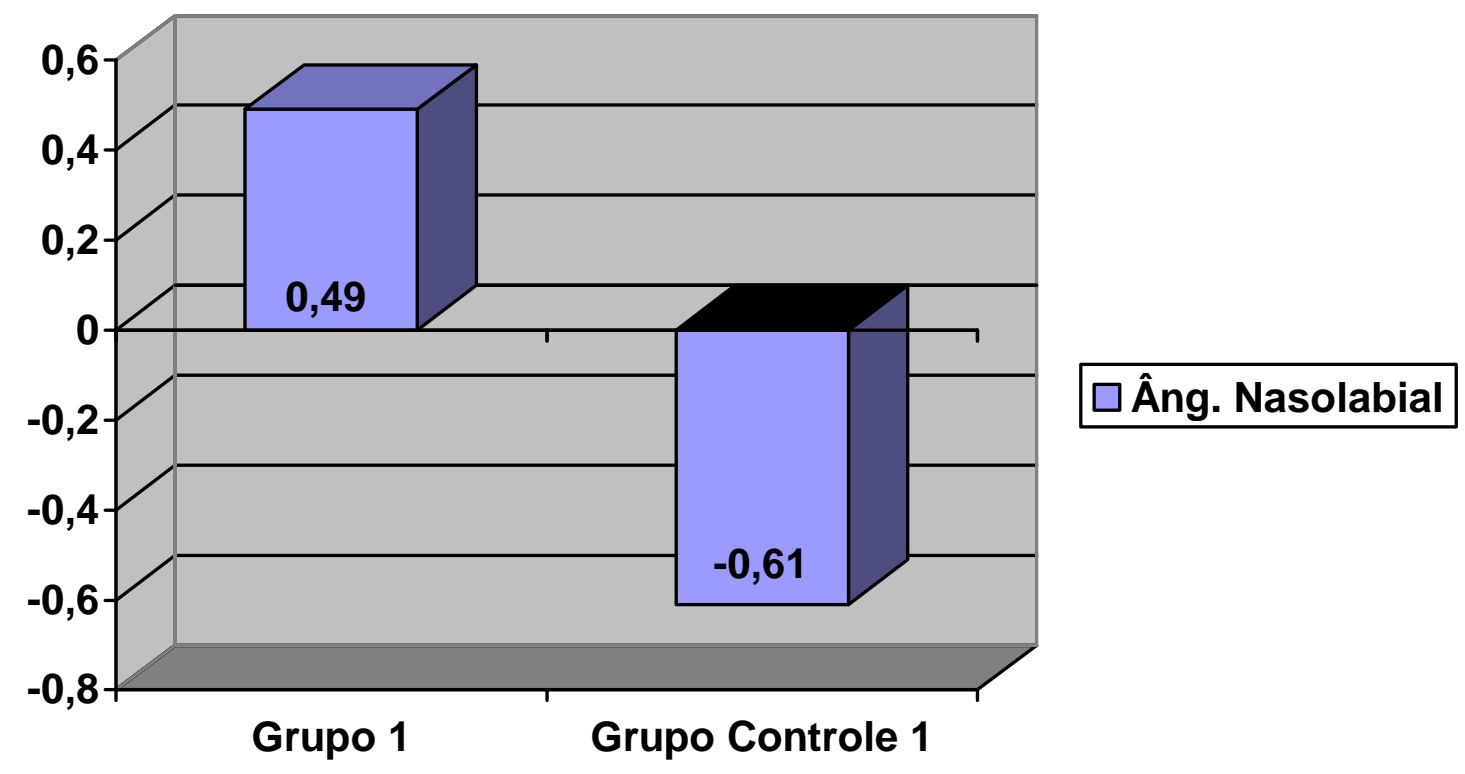

FIGURA 22 - Componente Tegumentar $\left(^{\circ}\right)$ - Ângulo Nasolabial

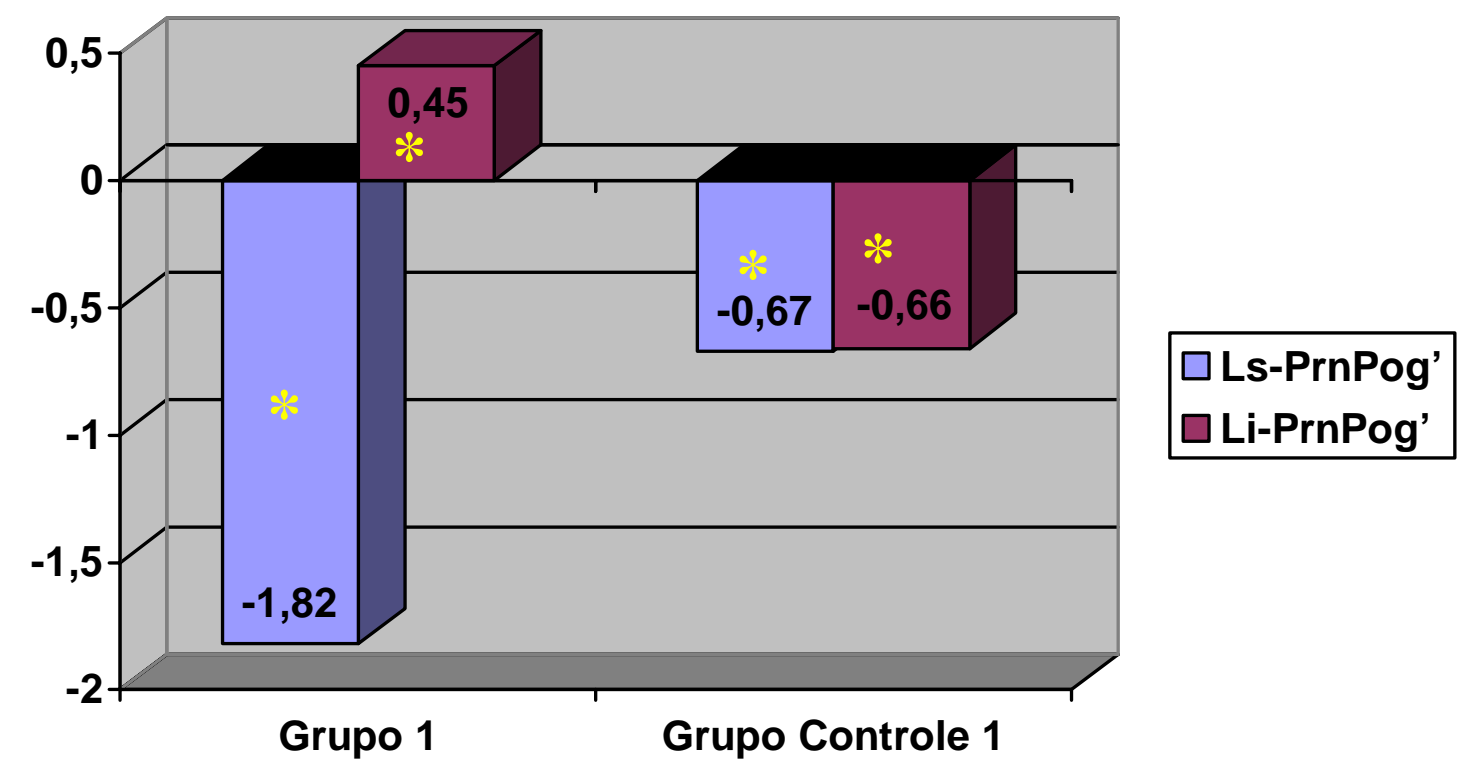

FIGURA 23 - Componente Tegumentar (mm) - Ls-PrnPog'; Li-PrnPog' 
TABELA 6 - Comparação intergrupos (Grupo 2 e Grupo Controle 2) na fase pré-tratamento, $\mathrm{T}_{1}$ (teste $\mathrm{t}$ )

\begin{tabular}{|c|c|c|c|c|c|}
\hline & \multicolumn{2}{|c|}{ Grupo 2} & \multicolumn{2}{|c|}{ Grupo Controle 2} & \multirow[t]{2}{*}{ p } \\
\hline Variável & $\mathrm{X}$ & D.P. & $\mathrm{X}$ & D.P. & \\
\hline \multicolumn{6}{|c|}{ Componente Maxilar } \\
\hline S.N.A & 81,25 & 3,85 & 80,42 & 3,88 & 0,428 \\
\hline Co-A & 86,89 & 3,61 & 87,33 & 3,85 & 0,664 \\
\hline \multicolumn{6}{|c|}{ Componente Mandibular } \\
\hline S.N.B & 74,84 & 2,86 & 76,25 & 3,40 & 0,104 \\
\hline Co-Gn & 108,10 & 5,06 & 109,02 & 3,66 & 0,434 \\
\hline \multicolumn{6}{|c|}{ Relação Maxilomandibular } \\
\hline A.N.B & 6,39 & 2,21 & 4,12 & 1,74 & $0,000^{*}$ \\
\hline N.A.Pog & 12,38 & 5,35 & 6,23 & 3,63 & $0,000^{*}$ \\
\hline \multicolumn{6}{|c|}{ Componente Vertical } \\
\hline PoOr.PP & 4,96 & 2,90 & 2,56 & 2,70 & $0,002^{*}$ \\
\hline PoOr.GoMe & 27,66 & 4,53 & 22,74 & 3,91 & $0,000^{*}$ \\
\hline PoOr.PO & 6,64 & 3,24 & 7,39 & 3,74 & 0,432 \\
\hline ENA-Me & 67,97 & 4,48 & 62,01 & 3,07 & $0,000^{*}$ \\
\hline $\mathrm{N}-\mathrm{Me}$ & 115,07 & 5,53 & 110,32 & 4,59 & $0,001^{*}$ \\
\hline S-Go & 69,06 & 3,78 & 70,28 & 4,24 & 0,266 \\
\hline \multicolumn{6}{|c|}{ Componente Dento-alveolar Superior } \\
\hline 1.NA & 24,55 & 5,85 & 22,06 & 5,99 & 0,124 \\
\hline$\overline{1-N A}$ & 4,84 & 2,44 & 3,12 & 1,84 & $0,004^{*}$ \\
\hline$\overline{1}$ 1.PP & 112,32 & 5,19 & 109,54 & 6,42 & 0,086 \\
\hline 1-PP & 29,39 & 2,36 & 26,71 & 2,16 & $0,000^{*}$ \\
\hline 6.PP & 106,68 & 4,43 & 103,29 & 3,57 & $0,002^{*}$ \\
\hline 6-PP & 20,52 & 2,03 & 19,21 & 1,62 & $0,010^{*}$ \\
\hline 1-SPerpPO & 82,70 & 4,31 & 79,48 & 3,91 & $0,005^{*}$ \\
\hline 6-SPerpPO & 49,57 & 4,78 & 49,35 & 3,48 & 0,843 \\
\hline \multicolumn{6}{|c|}{ Componente Dento-alveolar Inferior } \\
\hline 1.NB & 30,45 & 7,17 & 25,22 & 5,10 & $0,002^{*}$ \\
\hline$\overline{1}-\mathrm{NB}$ & 6,31 & 2,37 & 3,71 & 1,76 & $0,000^{*}$ \\
\hline$\overline{1}$.GoMe & 96,47 & 6,24 & 96,57 & 5,49 & 0,949 \\
\hline$\overline{1}-$ GoMe & 40,48 & 2,40 & 37,12 & 2,15 & $0,000^{*}$ \\
\hline$\overline{6}$.GoMe & 82,66 & 3,84 & 86,83 & 2,89 & $0,000^{*}$ \\
\hline$\overline{6}$-GoMe & 28,24 & 2,15 & 27,21 & 1,74 & 0,053 \\
\hline 1-SPerpPO & 75,56 & 4,97 & 74,67 & 3,74 & 0,448 \\
\hline$\overline{6}$-SPerpPO & 47,97 & 5,22 & 47,96 & 3,16 & 0,993 \\
\hline \multicolumn{6}{|c|}{ Relação Interdentária } \\
\hline Sobressaliência & 7,13 & 2,02 & 4,78 & 1,57 & $0,000^{*}$ \\
\hline Relação Molar & $-0,07$ & 1,24 & $-0,29$ & 0,85 & 0,435 \\
\hline \multicolumn{6}{|c|}{ Componente Tegumentar } \\
\hline Âng. Nasolabial & 107,49 & 10,80 & 118,41 & 8,00 & $0,000^{*}$ \\
\hline Ls-PrnPog' & 1,12 & 1,98 & $-2,32$ & 1,99 & $0,000^{*}$ \\
\hline Li-PrnPog' & 3,44 & 2,32 & $-1,66$ & 2,00 & $0,000^{*}$ \\
\hline
\end{tabular}

* diferença estatisticamente significante $(p<0,05)$ 

pareado)

TABELA 7 - Alterações do tratamento com o aparelho Extrabucal (teste $\mathrm{t}$

\begin{tabular}{|c|c|c|c|c|c|}
\hline & \multicolumn{2}{|c|}{$T_{1}$} & \multicolumn{2}{|c|}{$T_{2}$} & \multirow[t]{2}{*}{$\mathbf{p}$} \\
\hline Variável & $\mathrm{X}$ & D.P. & $\mathrm{X}$ & D.P. & \\
\hline \multicolumn{6}{|c|}{ Componente Maxilar } \\
\hline S.N.A & 81,25 & 3,85 & 80,22 & 3,39 & $0,007^{*}$ \\
\hline Co-A & 86,89 & 3,61 & 88,32 & 4,18 & $0,003^{*}$ \\
\hline \multicolumn{6}{|c|}{ Componente Mandibular } \\
\hline S.N.B & 74,84 & 2,86 & 75,12 & 2,57 & 0,295 \\
\hline Co-Gn & 108,10 & 5,06 & 112,05 & 5,76 & $0,000^{*}$ \\
\hline \multicolumn{6}{|c|}{ Relação Maxilomandibular } \\
\hline A.N.B & 6,39 & 2,21 & 5,10 & 2,21 & $0,000^{*}$ \\
\hline N.A.Pog & 12,38 & 5,35 & 9,40 & 5,53 & $0,000^{*}$ \\
\hline \multicolumn{6}{|c|}{ Componente Vertical } \\
\hline PoOr.PP & 4,96 & 2,90 & 2,78 & 3,20 & $0,000^{*}$ \\
\hline PoOr.GoMe & 27,66 & 4,53 & 28,07 & 4,01 & 0,397 \\
\hline PoOr.PO & 6,64 & 3,24 & 8,46 & 3,80 & $0,004^{*}$ \\
\hline ENA-Me & 67,97 & 4,48 & 69,62 & 4,59 & $0,000^{*}$ \\
\hline $\mathrm{N}-\mathrm{Me}$ & 115,07 & 5,53 & 119,66 & 6,38 & $0,000^{*}$ \\
\hline S-Go & 69,06 & 3,78 & 72,33 & 4,57 & $0,000^{*}$ \\
\hline \multicolumn{6}{|c|}{ Componente Dento-alveolar Superior } \\
\hline 1.NA & 24,55 & 5,85 & 24,35 & 5,02 & 0,745 \\
\hline$\overline{1-N A}$ & 4,84 & 2,44 & 5,03 & 2,39 & 0,613 \\
\hline$\overline{1} . \mathrm{PP}$ & 112,32 & 5,19 & 112,26 & 4,65 & 0,919 \\
\hline 1-PP & 29,39 & 2,36 & 30,44 & 2,21 & $0,000^{*}$ \\
\hline 6.PP & 106,68 & 4,43 & 107,06 & 7,45 & 0,753 \\
\hline$\underline{6}-P P$ & 20,52 & 2,03 & 21,00 & 2,19 & 0,192 \\
\hline 1-SPerpPO & 82,70 & 4,31 & 83,91 & 4,37 & $0,000^{*}$ \\
\hline 6-SPerpPO & 49,57 & 4,78 & 49,60 & 4,80 & 0,931 \\
\hline \multicolumn{6}{|c|}{ Componente Dento-alveolar Inferior } \\
\hline 1.NB & 30,45 & 7,17 & 28,48 & 6,55 & $0,003^{*}$ \\
\hline$\overline{1}-\mathrm{NB}$ & 6,31 & 2,37 & 6,31 & 2,50 & 0,983 \\
\hline 1.GoMe & 96,47 & 6,24 & 94,82 & 5,21 & $0,005^{*}$ \\
\hline$\overline{1}-$ GoMe & 40,48 & 2,40 & 41,86 & 2,68 & $0,000^{*}$ \\
\hline$\overline{6}$. GoMe & 82,66 & 3,84 & 81,17 & 3,66 & $0,040^{*}$ \\
\hline$\overline{\overline{6}}$-GoMe & 28,24 & 2,15 & 30,08 & 2,25 & $0,000^{*}$ \\
\hline$\overline{1}$-SPerpPO & 75,56 & 4,97 & 78,12 & 5,02 & $0,000^{*}$ \\
\hline$\overline{6}$-SPerpPO & 47,97 & 5,22 & 52,02 & 5,31 & $0,000^{*}$ \\
\hline \multicolumn{6}{|c|}{ Relação Interdentária } \\
\hline Sobressaliência & 7,13 & 2,02 & 5,79 & 1,92 & $0,000^{*}$ \\
\hline Relação Molar & $-0,07$ & 1,24 & $-3,97$ & 1,57 & $0,000^{*}$ \\
\hline \multicolumn{6}{|c|}{ Componente Tegumentar } \\
\hline Âng. Nasolabial & 107,49 & 10,80 & 106,45 & 9,80 & 0,486 \\
\hline Ls-PrnPog' & 1,12 & 1,98 & $-0,48$ & 2,38 & $0,000^{*}$ \\
\hline Li-PrnPog' & 3,44 & 2,32 & 2,77 & 2,30 & $0,007^{*}$ \\
\hline
\end{tabular}

* diferença estatisticamente significante $(p<0,05)$ 
TABELA 8 - Alterações normais com o crescimento no Grupo Controle 2, em período de tempo compatível com o Grupo 2 (teste t pareado)

\begin{tabular}{|c|c|c|c|c|c|}
\hline & \multicolumn{2}{|c|}{$\mathrm{T}_{1}$} & \multicolumn{2}{|c|}{$\mathrm{T}_{2}$} & \multirow[t]{2}{*}{$\mathbf{p}$} \\
\hline Variável & $\mathrm{X}$ & D.P. & $\mathrm{X}$ & D.P. & \\
\hline \multicolumn{6}{|c|}{ Componente Maxilar } \\
\hline S.N.A & 80,42 & 3,88 & 81,02 & 4,05 & $0,004^{*}$ \\
\hline Co-A & 87,33 & 3,85 & 89,48 & 3,98 & $0,000^{*}$ \\
\hline \multicolumn{6}{|c|}{ Componente Mandibular } \\
\hline S.N.B & 76,25 & 3,40 & 76,85 & 3,50 & $0,001^{*}$ \\
\hline Co-Gn & 109,02 & 3,66 & 112,18 & 3,71 & $0,000^{*}$ \\
\hline \multicolumn{6}{|c|}{ Relação Maxilomandibular } \\
\hline A.N.B & 4,12 & 1,74 & 4,10 & 1,71 & 0,819 \\
\hline N.A.Pog & 6,23 & 3,63 & 5,96 & 3,53 & 0,249 \\
\hline \multicolumn{6}{|c|}{ Componente Vertical } \\
\hline PoOr.PP & 2,56 & 2,70 & 2,39 & 2,89 & 0,492 \\
\hline PoOr.GoMe & 22,74 & 3,91 & 22,23 & 4,35 & 0,053 \\
\hline PoOr.PO & 7,39 & 3,74 & 6,76 & 4,32 & $0,014^{*}$ \\
\hline ENA-Me & 62,01 & 3,07 & 63,39 & 3,22 & $0,000^{*}$ \\
\hline $\mathrm{N}-\mathrm{Me}$ & 110,32 & 4,59 & 113,11 & 5,15 & $0,000^{*}$ \\
\hline S-Go & 70,28 & 4,24 & 72,77 & 4,27 & $0,000^{*}$ \\
\hline \multicolumn{6}{|c|}{ Componente Dento-alveolar Superior } \\
\hline 1.NA & 22,06 & 5,99 & 21,14 & 6.04 & $0.006^{*}$ \\
\hline 1-NA & 3,12 & 1,84 & 3,25 & 2,11 & 0,444 \\
\hline 1.PP & 109,54 & 6,42 & 109,25 & 6,28 & 0,326 \\
\hline 1-PP & 26,71 & 2,16 & 27,54 & 2,15 & $0,000^{*}$ \\
\hline 6.PP & 103,29 & 3,57 & 101,98 & 3,26 & $0,002^{*}$ \\
\hline 6-PP & 19,21 & 1,62 & 20,41 & 1,68 & $0,000^{*}$ \\
\hline 1-SPerpPO & 79,48 & 3,91 & 80,95 & 4,05 & $0,000^{*}$ \\
\hline 6-SPerpPO & 49,35 & 3,48 & 51,01 & 3,56 & $0,000^{*}$ \\
\hline \multicolumn{6}{|c|}{ Componente Dento-alveolar Inferior } \\
\hline $1 . N B$ & 25,22 & 5,10 & 25,70 & 4,86 & 0,085 \\
\hline$\overline{1}-\mathrm{NB}$ & 3,71 & 1,76 & 4,05 & 1,82 & $0,000^{*}$ \\
\hline 1.GoMe & 96,57 & 5,49 & 97,01 & 5,18 & 0,150 \\
\hline$\overline{1}$-GoMe & 37,12 & 2,15 & 37,88 & 2,27 & $0,000^{*}$ \\
\hline$\overline{6}$.GoMe & 86,83 & 2,89 & 86,95 & 3,28 & 0,698 \\
\hline$\overline{6}$-GoMe & 27,21 & 1,74 & 27,84 & 1,87 & $0,000^{*}$ \\
\hline$\overline{1}$-SPerpPO & 74,67 & 3,74 & 76,28 & 3,72 & $0,000^{*}$ \\
\hline$\overline{6}$-SPerpPO & 47,96 & 3,16 & 50,02 & 3,20 & $0,000^{*}$ \\
\hline \multicolumn{6}{|c|}{ Relação Interdentária } \\
\hline Sobressaliência & 4,78 & 1,57 & 4,62 & 1,60 & 0,188 \\
\hline Relação Molar & $-0,29$ & 0,85 & $-0,54$ & 1,25 & 0,062 \\
\hline \multicolumn{6}{|c|}{ Componente Tegumentar } \\
\hline Âng. Nasolabial & 118,41 & 8,00 & 116,64 & 10,51 & 0,148 \\
\hline Ls-PrnPog' & $-2,32$ & 1,99 & $-2,44$ & 2,00 & 0,586 \\
\hline Li-PrnPog' & $-1,66$ & 2,00 & $-1,72$ & 2,18 & 0,786 \\
\hline
\end{tabular}

* diferença estatisticamente significante $(p<0,05)$ 
TABELA 9 - Comparação entre as alterações do tratamento com o aparelho Extrabucal e as alterações do Grupo Controle 2 (teste t)

\begin{tabular}{|c|c|c|c|c|c|}
\hline & \multicolumn{2}{|c|}{ Grupo 2} & \multicolumn{2}{|c|}{ Grupo Controle 2} & \multirow[t]{2}{*}{$\mathbf{p}$} \\
\hline Variável & $\mathrm{X}$ & D.P. & $\mathrm{X}$ & D.P. & \\
\hline \multicolumn{6}{|c|}{ Componente Maxilar } \\
\hline S.N.A & $-1,02$ & 1,72 & 0,60 & 1,06 & $0,000^{*}$ \\
\hline Co-A & 1,42 & 2,16 & 2,14 & 1,03 & 0,107 \\
\hline \multicolumn{6}{|c|}{ Componente Mandibular } \\
\hline S.N.B & 0,28 & 1,34 & 0,60 & 0,90 & 0,291 \\
\hline Co-Gn & 3,95 & 2,89 & 3,16 & 1,14 & 0,169 \\
\hline \multicolumn{6}{|c|}{ Relação Maxilomandibular } \\
\hline A.N.B & $-1,29$ & 1,05 & $-0,02$ & 0,54 & $0,000^{*}$ \\
\hline N.A.Pog & $-2,98$ & 2,41 & $-0,27$ & 1,30 & $0,000^{*}$ \\
\hline \multicolumn{6}{|c|}{ Componente Vertical } \\
\hline PoOr.PP & $-2,18$ & 2,40 & $-0,17$ & 1,36 & $0,000^{*}$ \\
\hline PoOr.GoMe & 0,41 & 2,38 & $-0,50$ & 1,38 & 0,079 \\
\hline PoOr.PO & 1,82 & 2,89 & $-0,62$ & 1,34 & $0,000^{*}$ \\
\hline ENA-Me & 1,65 & 1,91 & 1,38 & 0,96 & 0,495 \\
\hline $\mathrm{N}-\mathrm{Me}$ & 4,59 & 2,83 & 2,78 & 1,16 & $0,002^{*}$ \\
\hline S-Go & 3,26 & 1,80 & 2,49 & 0,73 & $0,034^{*}$ \\
\hline \multicolumn{6}{|c|}{ Componente Dento-alveolar Superior } \\
\hline 1.NA & $-0,20$ & 3,03 & $-0,92$ & 1,73 & 0,269 \\
\hline 1-NA & 0,19 & 1,87 & 0,12 & 0,92 & 0,855 \\
\hline 1.PP & $-0,05$ & 2,73 & $-0,29$ & 1,63 & 0,685 \\
\hline 1-PP & 1,05 & 1,00 & 0,83 & 0,69 & 0,335 \\
\hline 6.PP & 0,38 & 6,03 & $-1,30$ & 2,16 & 0,155 \\
\hline 6-PP & 0,48 & 1,78 & 1,20 & 0,58 & $0,039^{*}$ \\
\hline 1-SPerpPO & 1,20 & 1,36 & 1,47 & 0,68 & 0,338 \\
\hline 6-SPerpPO & 0,02 & 1,59 & 1,66 & 0,88 & $0,000^{*}$ \\
\hline \multicolumn{6}{|c|}{ Componente Dento-alveolar Inferior } \\
\hline $1 . N B$ & $-1,96$ & 2,92 & 0,47 & 1,49 & $0,000^{*}$ \\
\hline$\overline{1}-\mathrm{NB}$ & 0,00 & 0,92 & 0,34 & 0,43 & 0,073 \\
\hline$\overline{1}$.GoMe & $-1,65$ & 2,68 & 0,44 & 1,66 & $0,001^{*}$ \\
\hline$\overline{1}$-GoMe & 1,38 & 1,24 & 0,76 & 0,38 & $0,011^{*}$ \\
\hline$\overline{6}$.GoMe & $-1,49$ & 3,42 & 0,12 & 1,74 & $0,026^{*}$ \\
\hline$\overline{6}$-GoMe & 1,84 & 0,72 & 0,62 & 0,45 & $0,000^{*}$ \\
\hline 1-SPerpPO & 2,55 & 1,67 & 1,60 & 0,80 & $0,007^{*}$ \\
\hline$\overline{6}$-SPerpPO & 4,04 & 1,65 & 2,05 & 1,05 & $0,000^{*}$ \\
\hline \multicolumn{6}{|c|}{ Relação Interdentária } \\
\hline Sobressaliência & $-1,34$ & 1,41 & $-0,15$ & 0,63 & $0,000^{*}$ \\
\hline Relação Molar & $-3,89$ & 1,19 & $-0,25$ & 0,73 & $0,000^{*}$ \\
\hline \multicolumn{6}{|c|}{ Componente Tegumentar } \\
\hline Âng. Nasolabial & $-1,04$ & 7,37 & $-1,76$ & 6,61 & 0,702 \\
\hline Ls-PrnPog' & $-1,60$ & 1,09 & $-0,11$ & 1,20 & $0,000^{*}$ \\
\hline Li-PrnPog' & $-0,67$ & 1,13 & $-0,06$ & 1,17 & 0,054 \\
\hline
\end{tabular}

* diferença estatisticamente significante $(p<0,05)$ 


\section{REPRESENTAÇÕES GRÁFICAS}

\section{Grupo 2 x Grupo Controle 2}

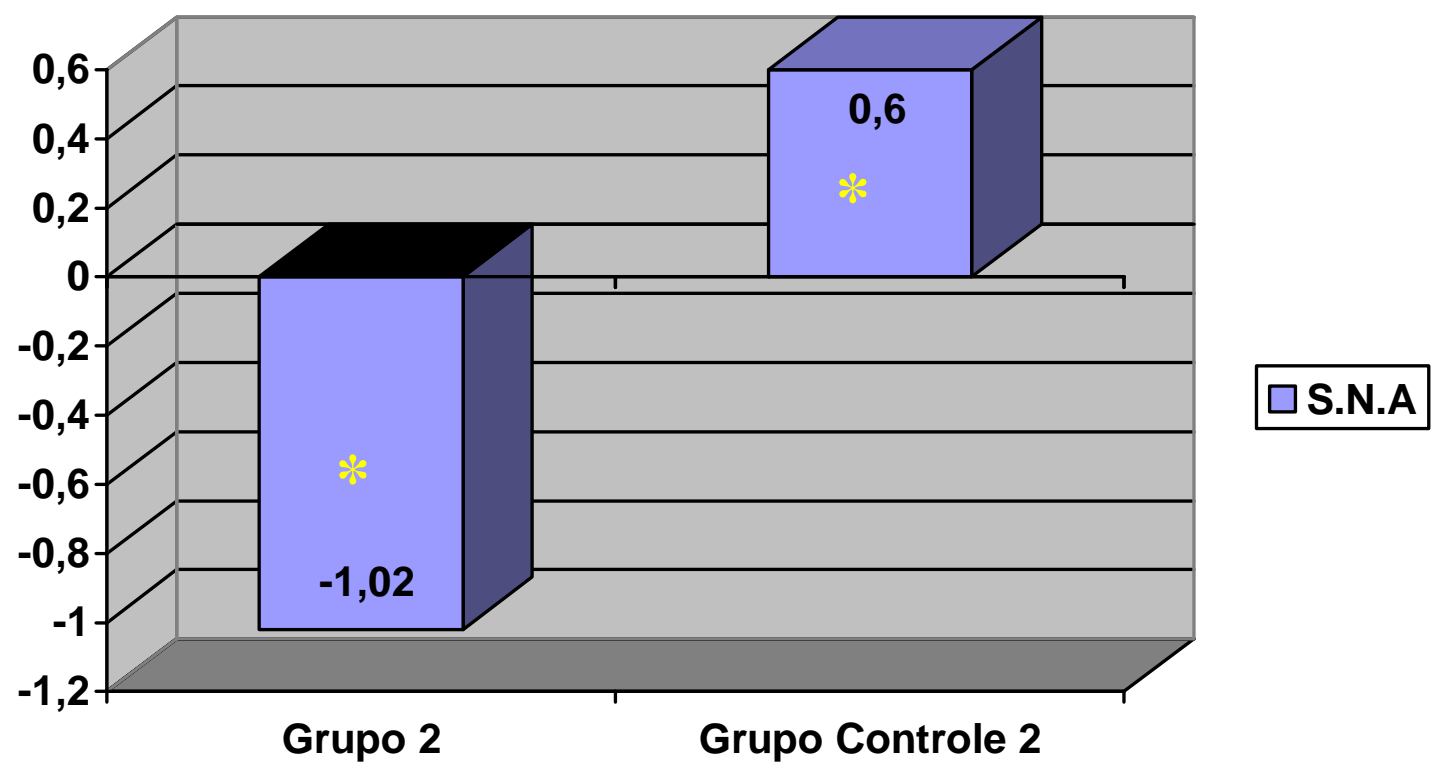

FIGURA 24 - Componente Maxilar $\left(^{\circ}\right)$ - S.N.A

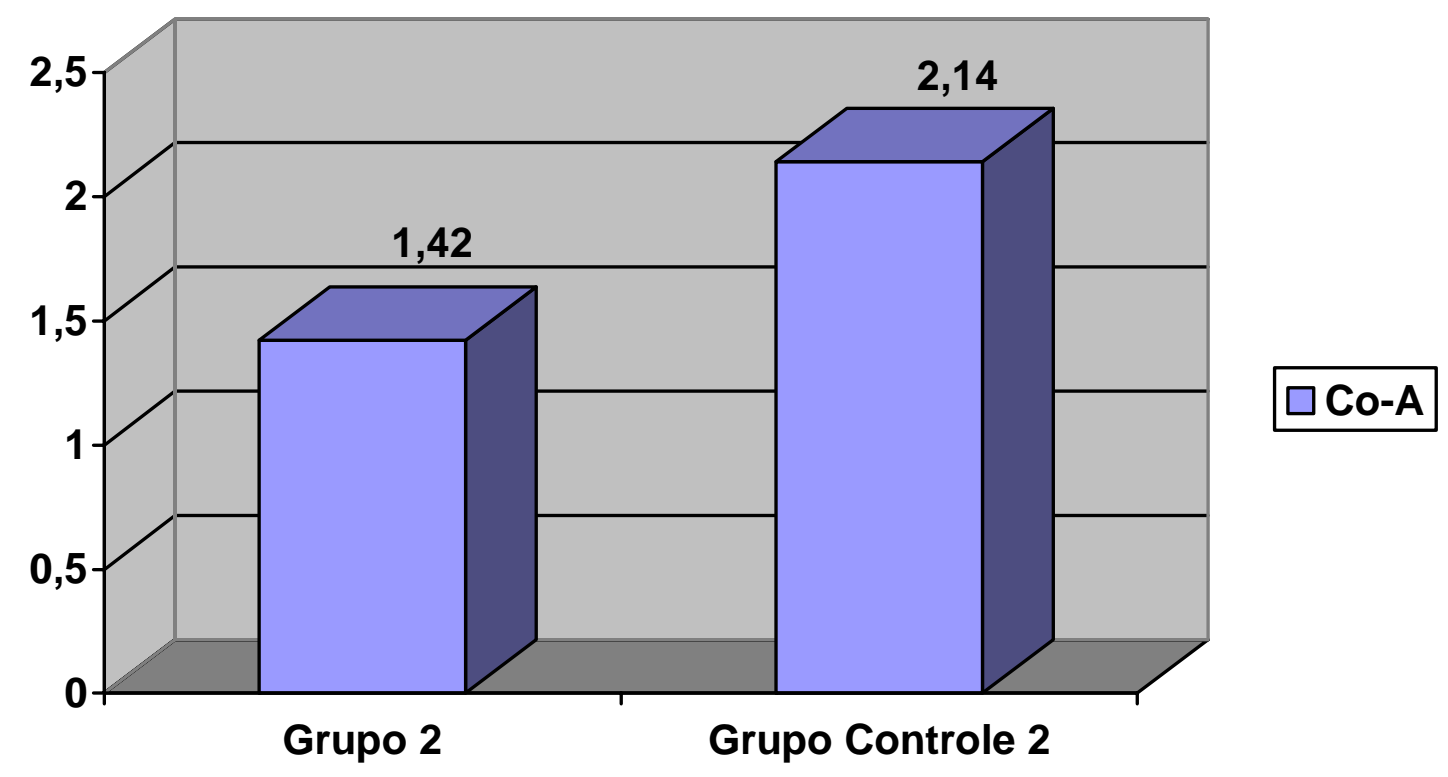

FIGURA 25 - Componente Maxilar (mm) - Co-A 


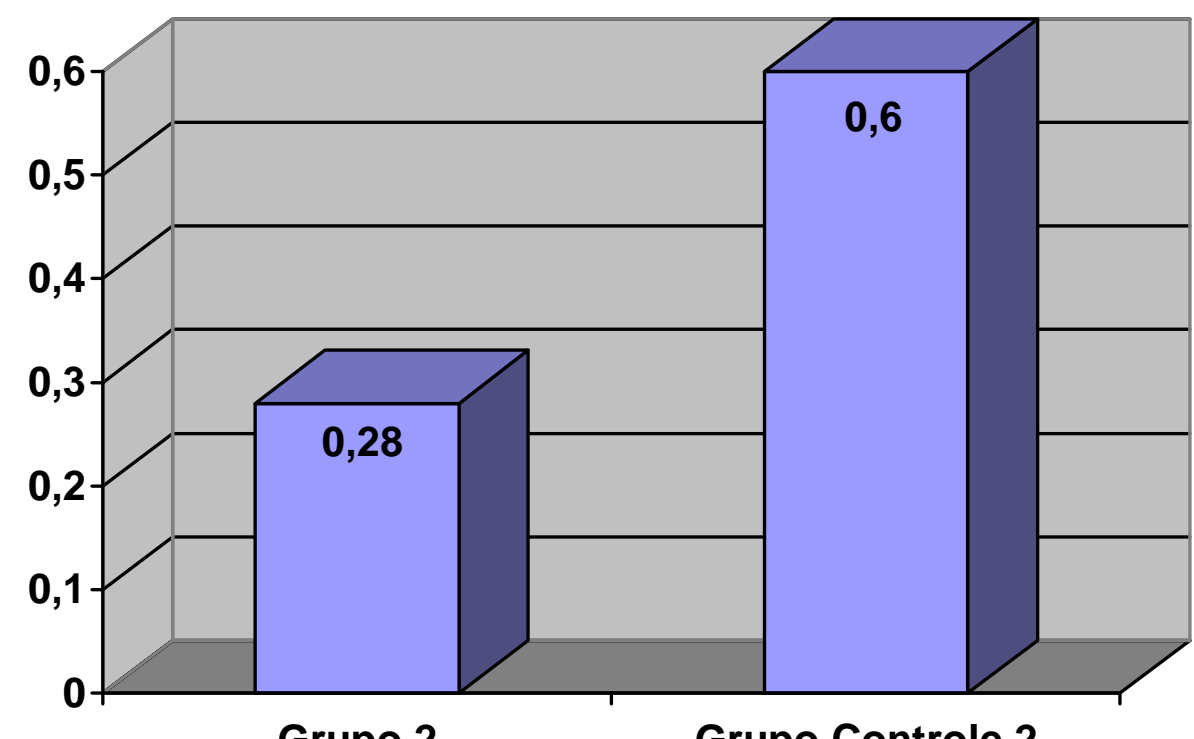

$\square$ S.N.B

Grupo 2

Grupo Controle 2

FIGURA 26 - Componente Mandibular $\left({ }^{\circ}\right)$ - S.N.B

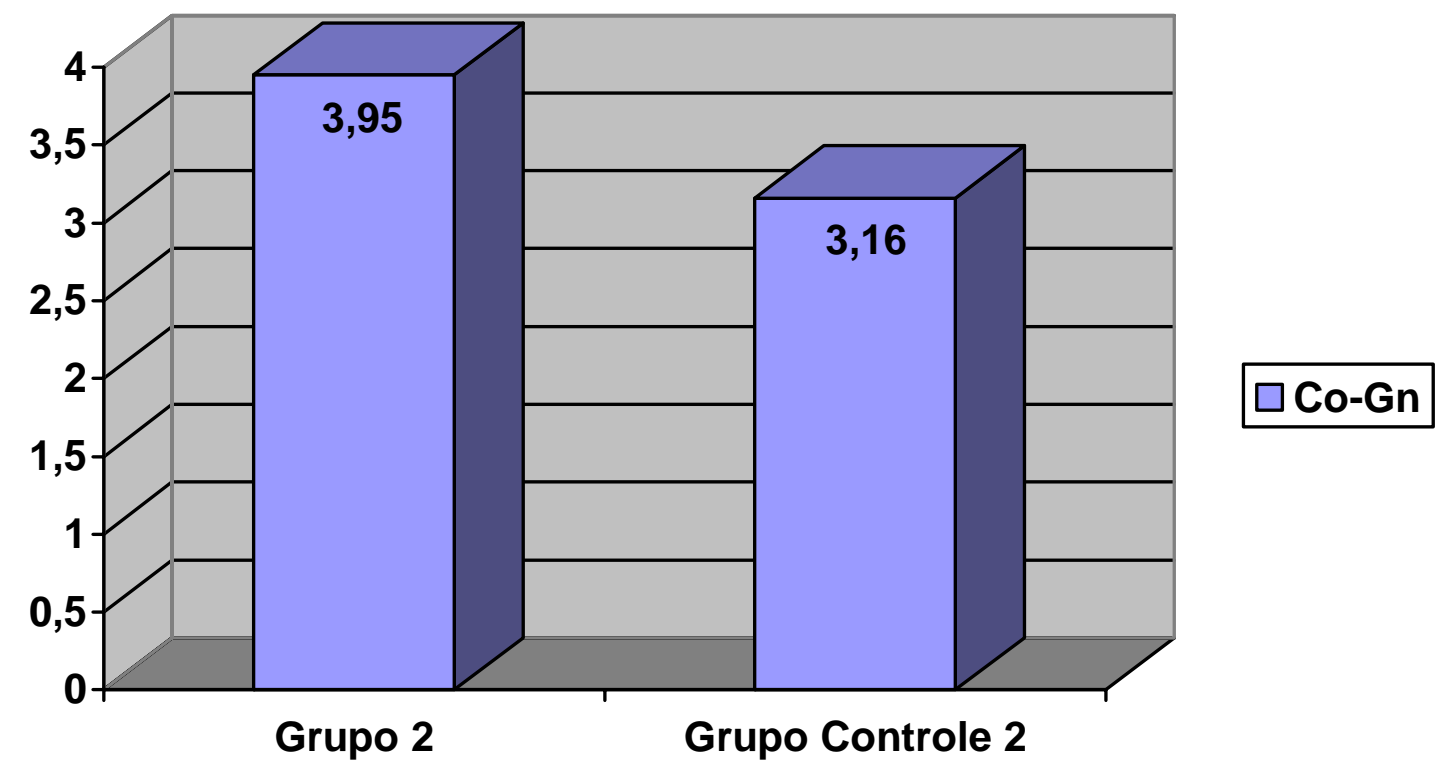

FIGURA 27 - Componente Mandibular (mm) - Co-Gn 


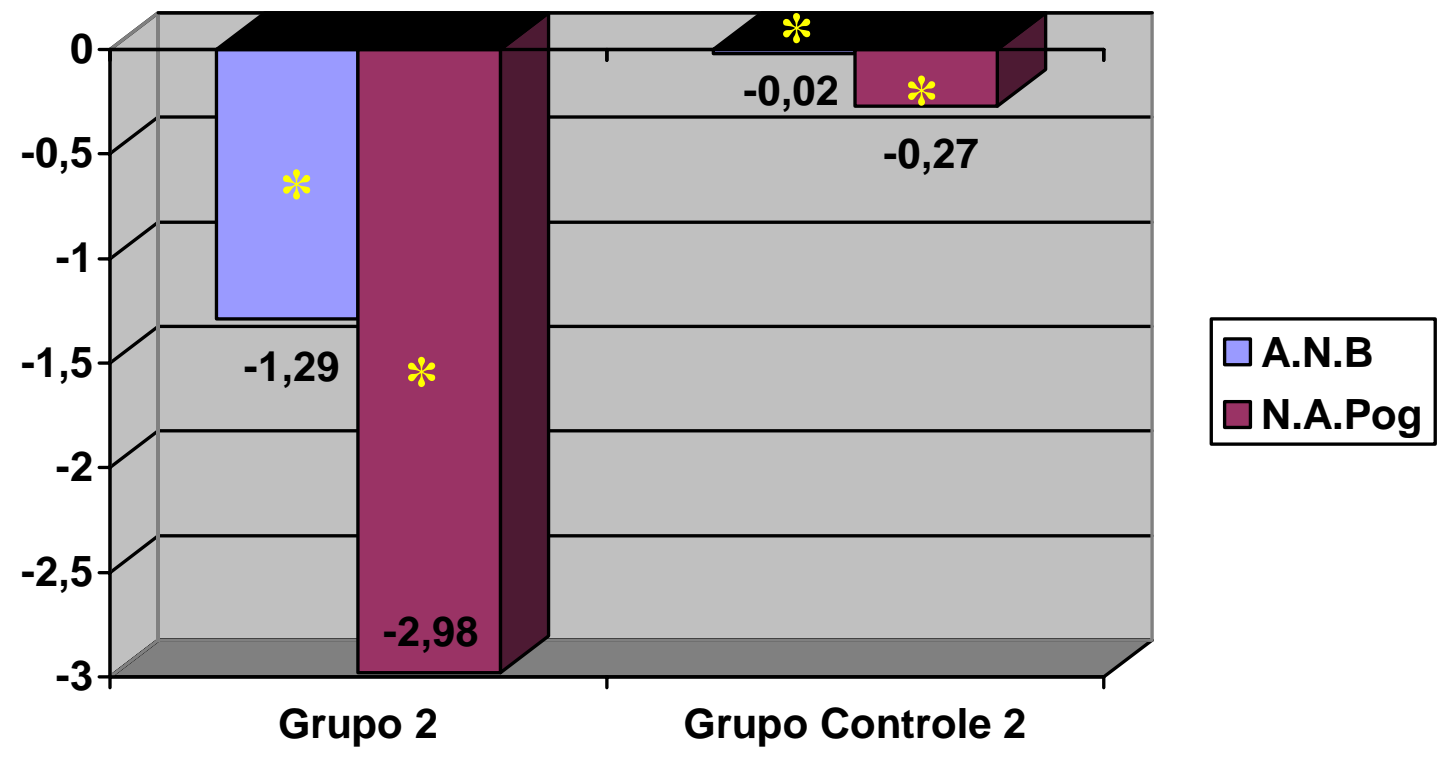

FIGURA 28 - Relação Maxilomandibular $\left({ }^{\circ}\right)$ - A.N.B; N.A.Pog

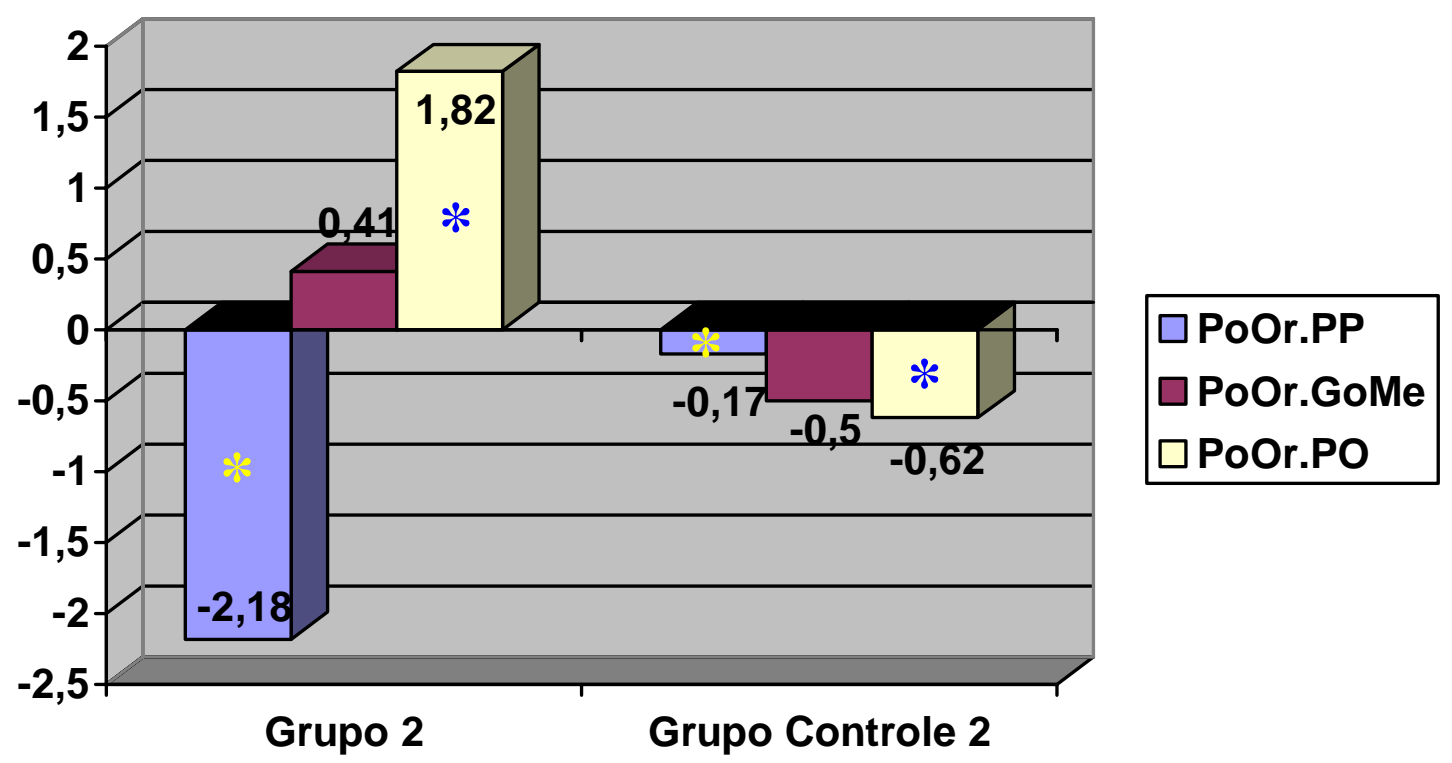

FIGURA 29 - Componente Vertical $\left({ }^{\circ}\right)$ - PoOr.PP; PoOr.GoMe; PoOr.PO 


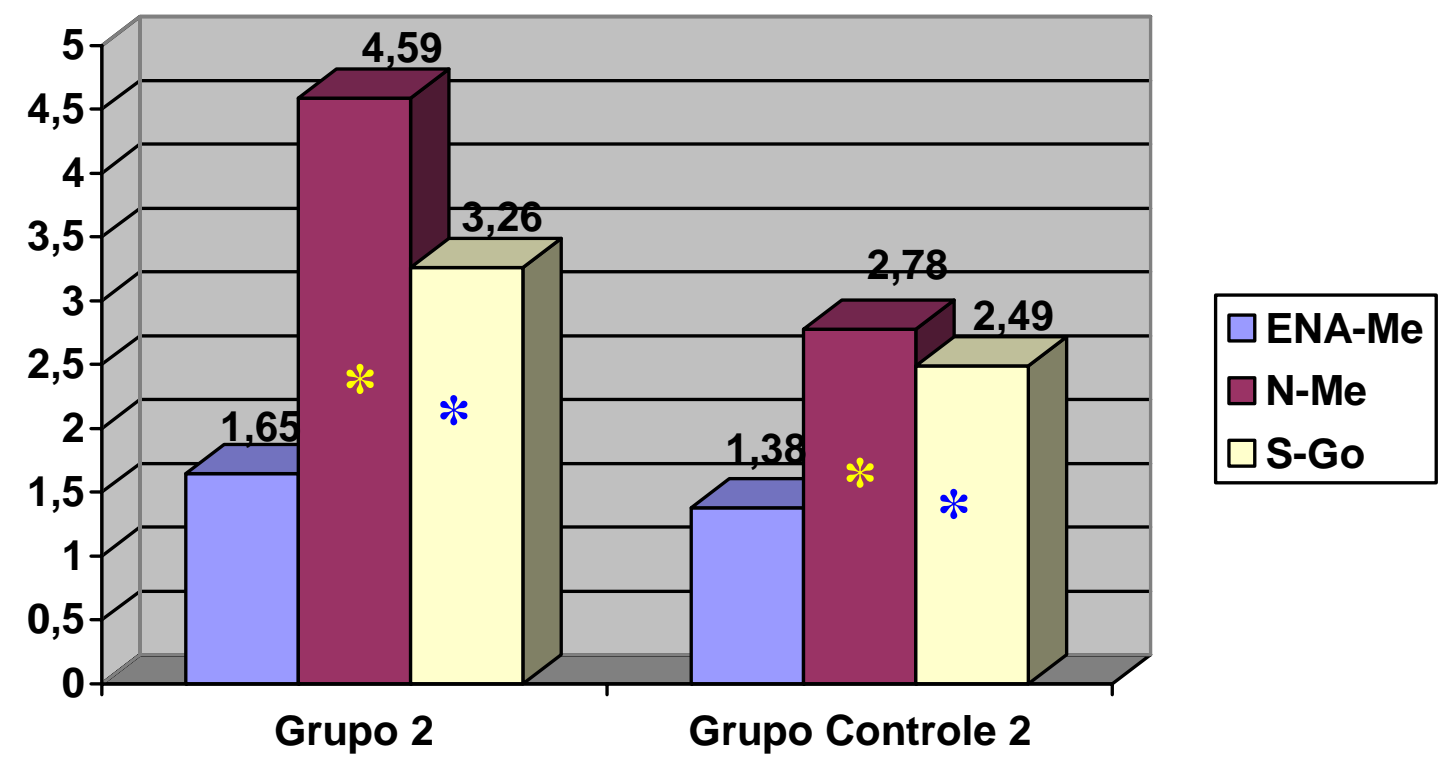

FIGURA 30 - Componente Vertical (mm) - ENA-Me; N-Me; S-Go

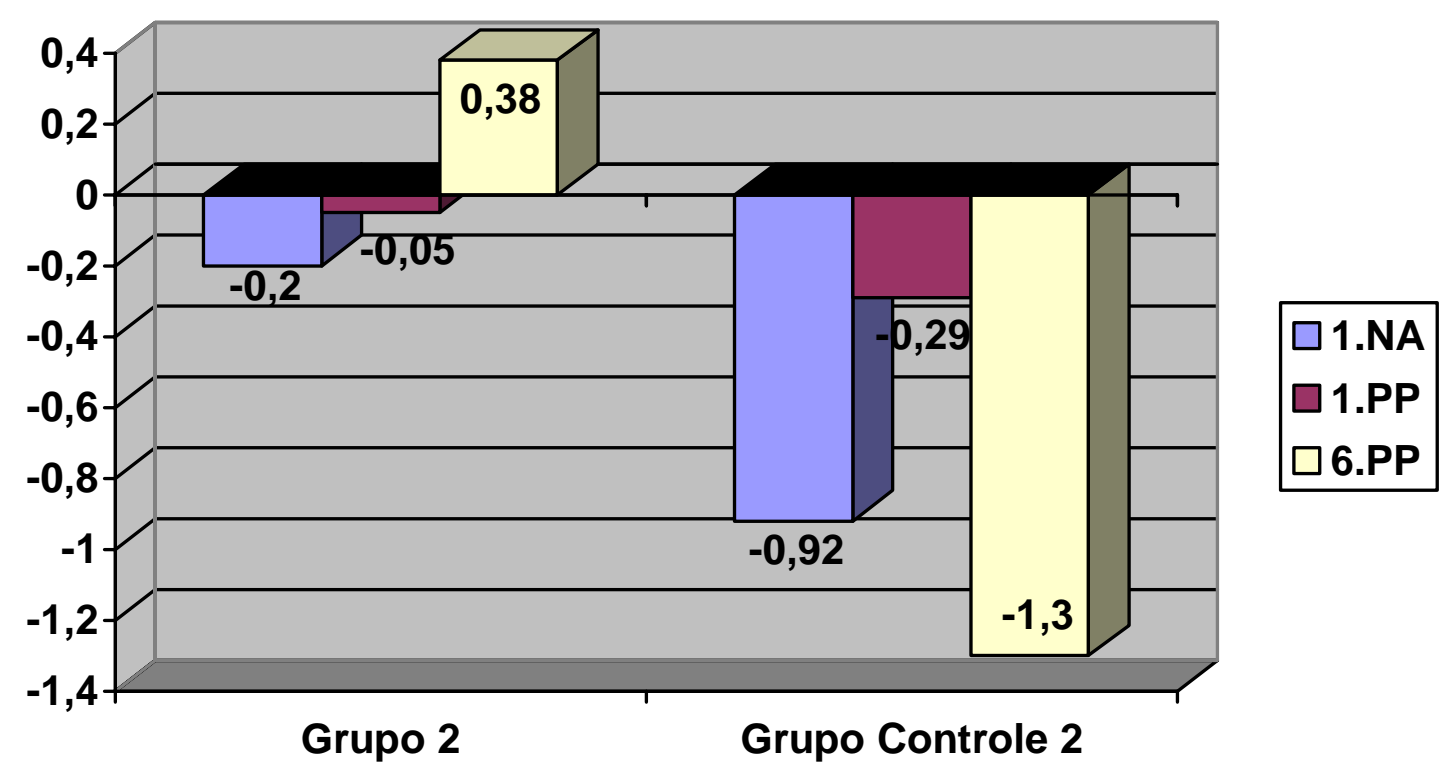

FIGURA 31 - Componente Dento-alveolar Superior $\left({ }^{\circ}\right)$ - 1..$N A ; \underline{1} . P P ; \underline{6} . P P$ 


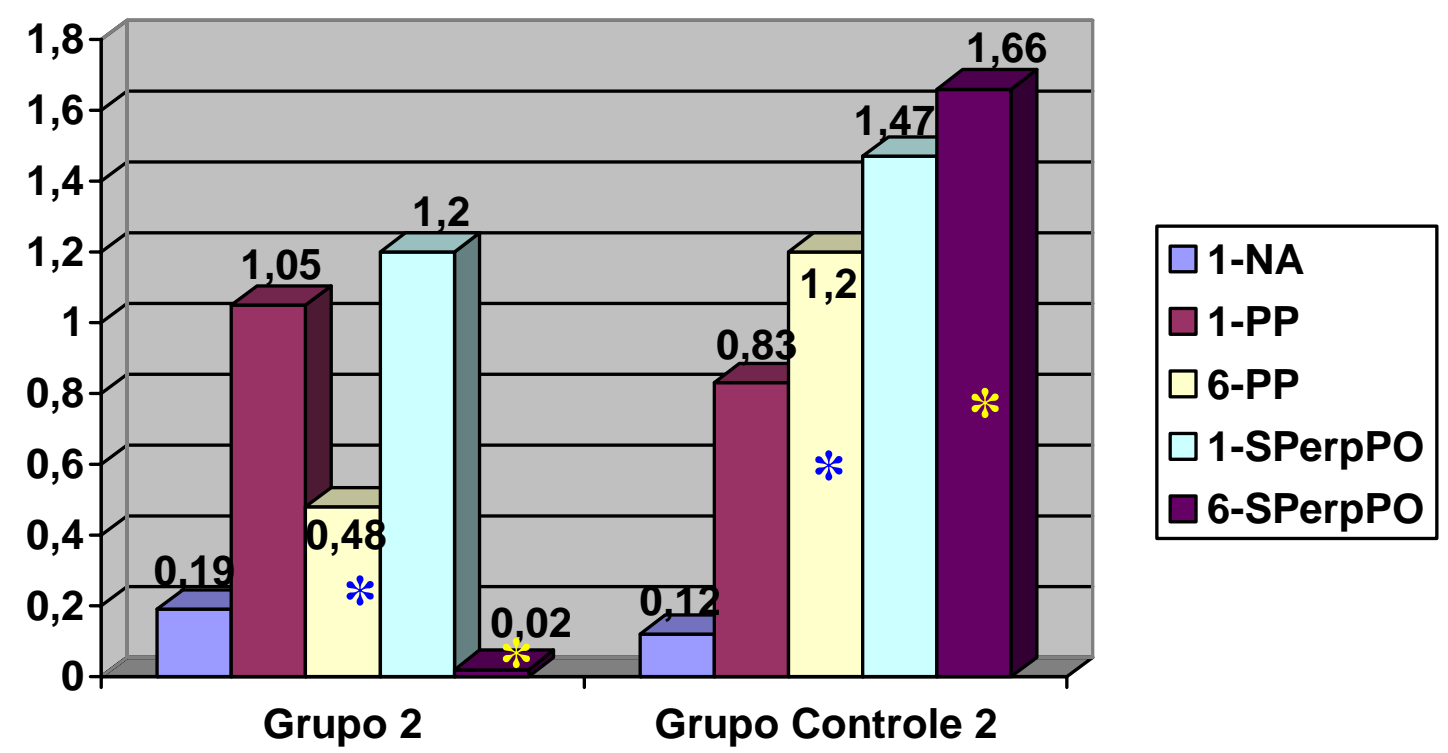

FIGURA 32 - Componente Dento-alveolar Superior (mm) - $\underline{1}-N A ; \underline{1}-P P ; \underline{6}-P P$; 1-SPerpPO; $\underline{6}$-SPerpPO

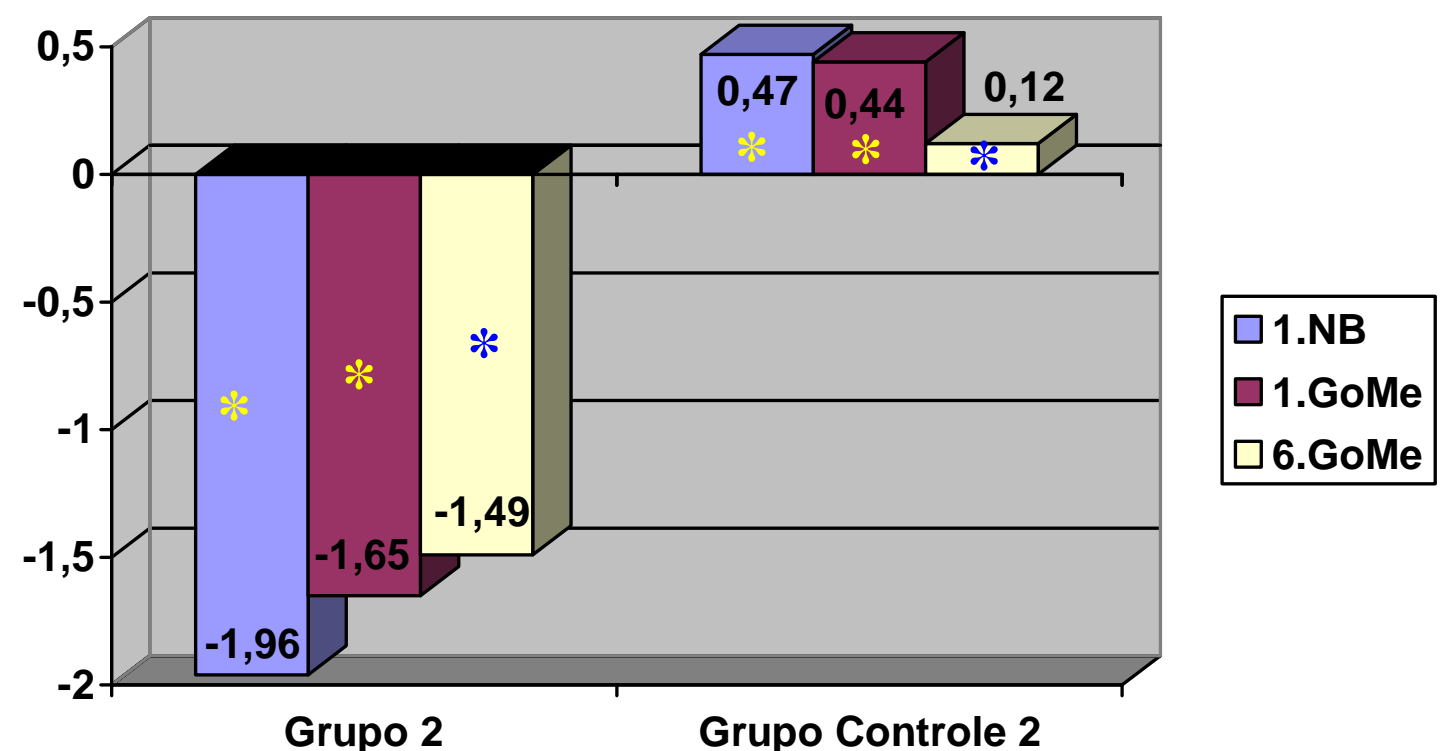

FIGURA 33 - Componente Dento-alveolar Inferior $\left(^{\circ}\right)-\overline{1} . N B ; \overline{1} . G o M e ; \overline{6} . G o M e$ 


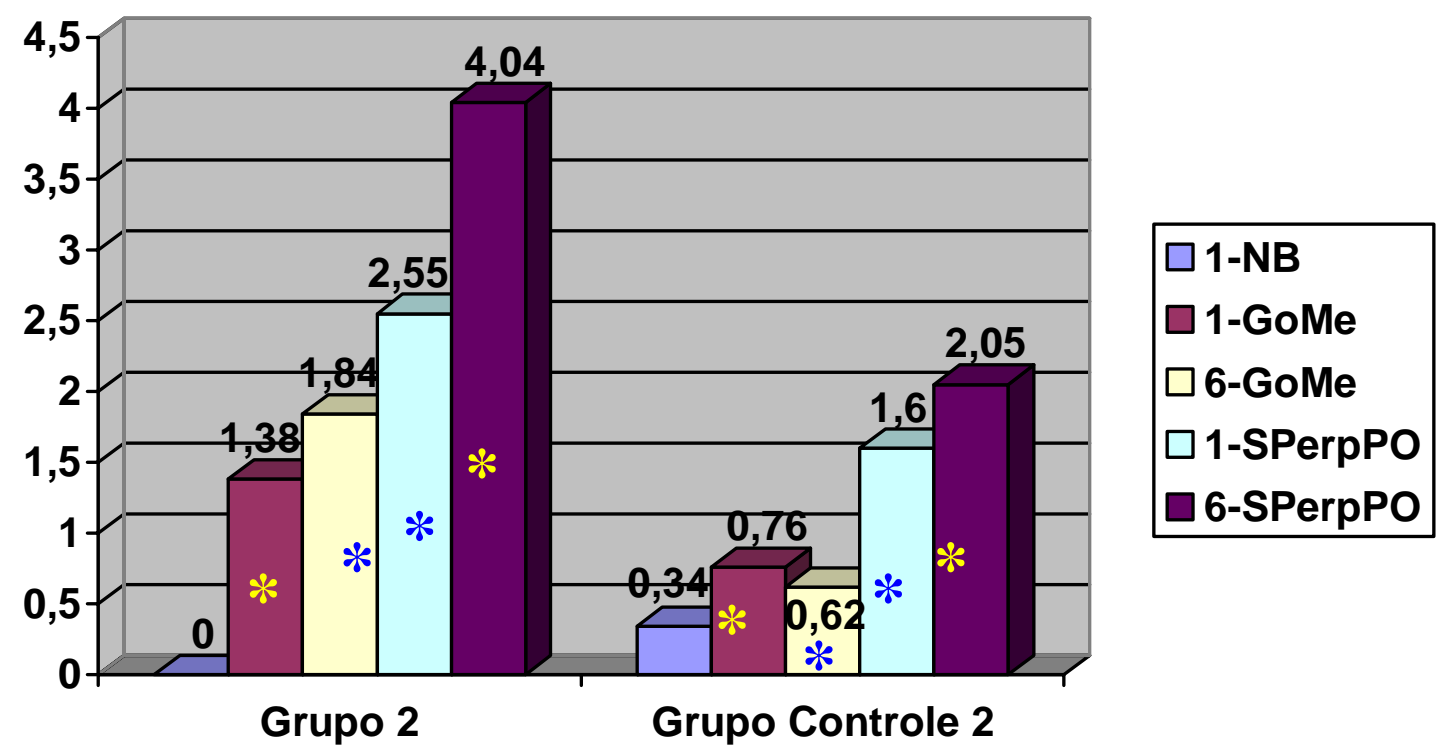

FIGURA 34 - Componente Dento-alveolar Inferior (mm) - $\overline{1}-N B ; \overline{1}$-GoMe; $\overline{6}$-GoMe; $\overline{1}$-SPerpPO; $\overline{6}$-SPerpPO

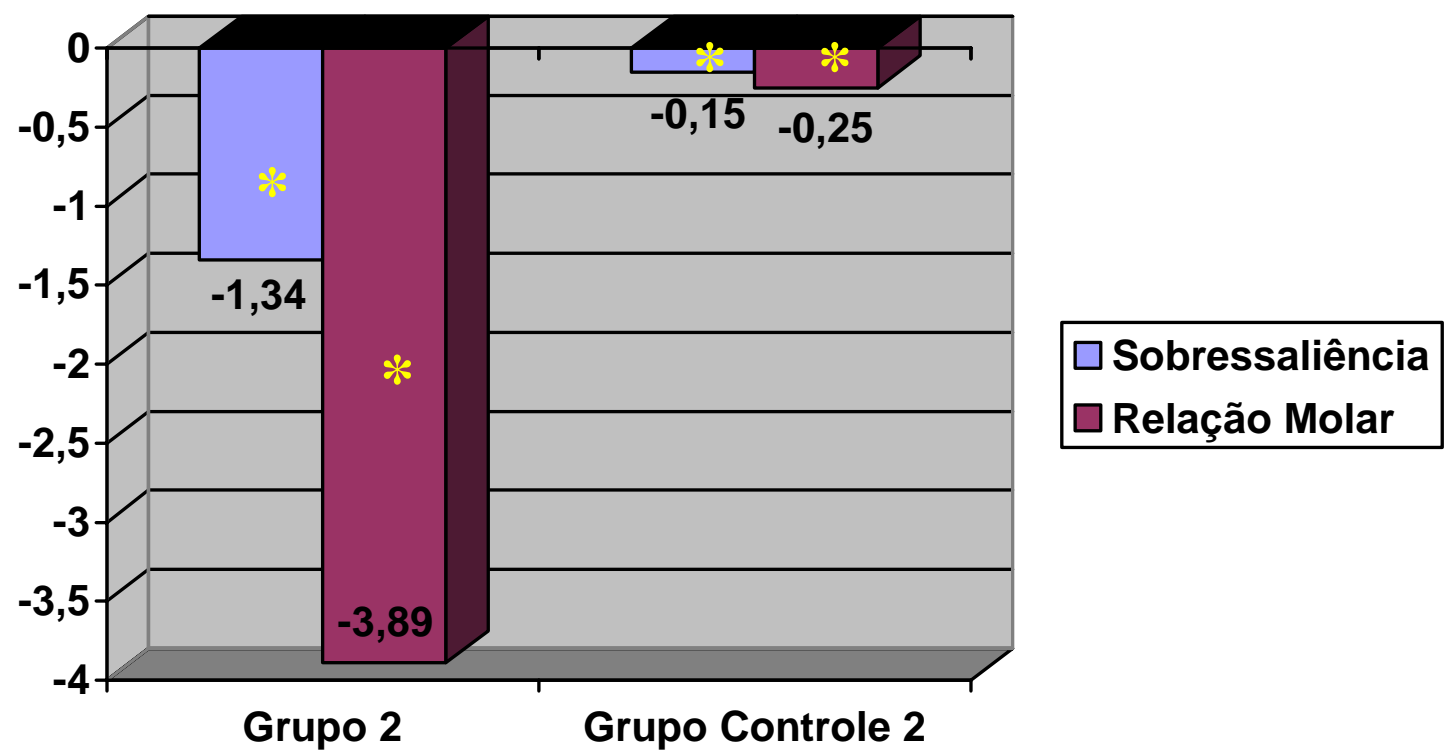

FIGURA 35 - Relação Interdentária (mm) - Sobressaliência; Relação Molar 


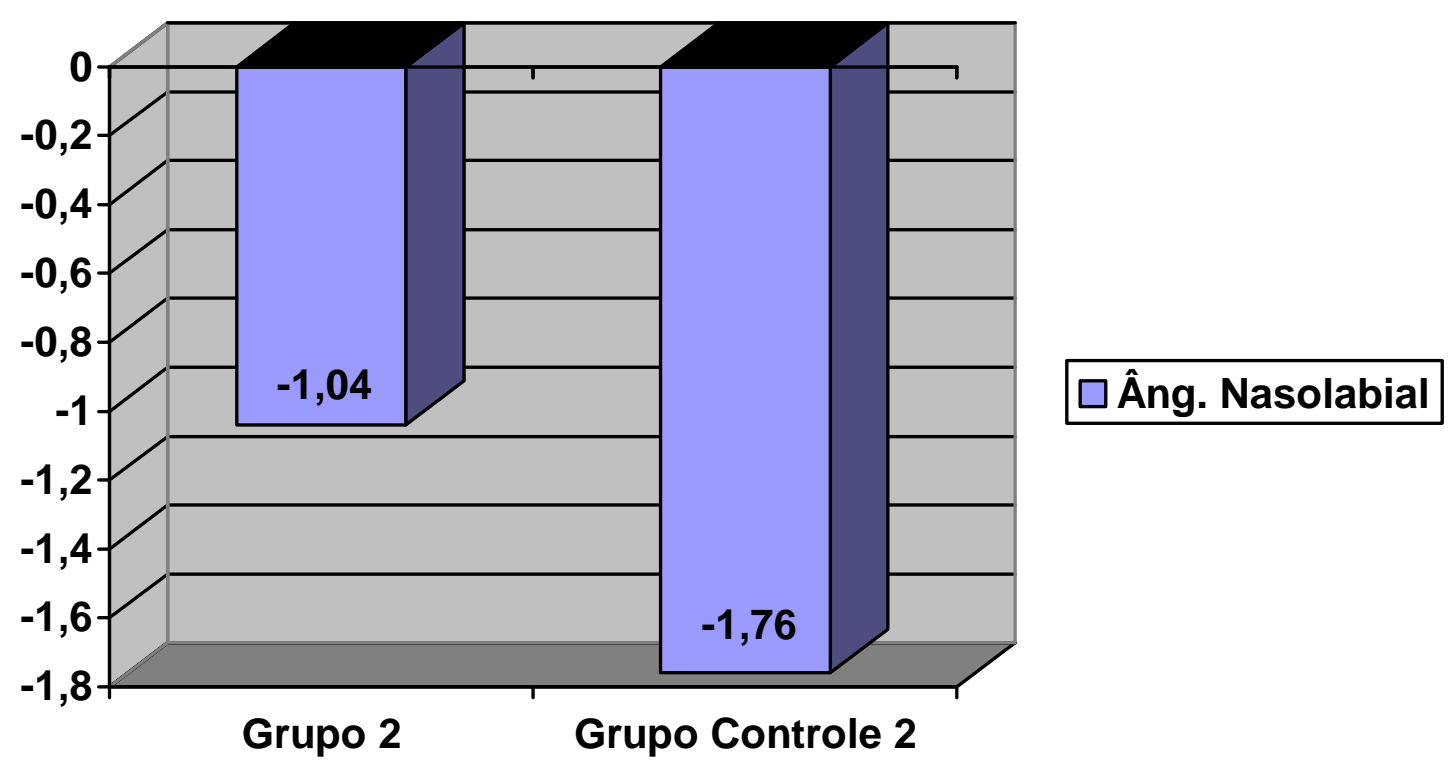

FIGURA 36 - Componente Tegumentar $\left(^{\circ}\right)$ - Ângulo Nasolabial

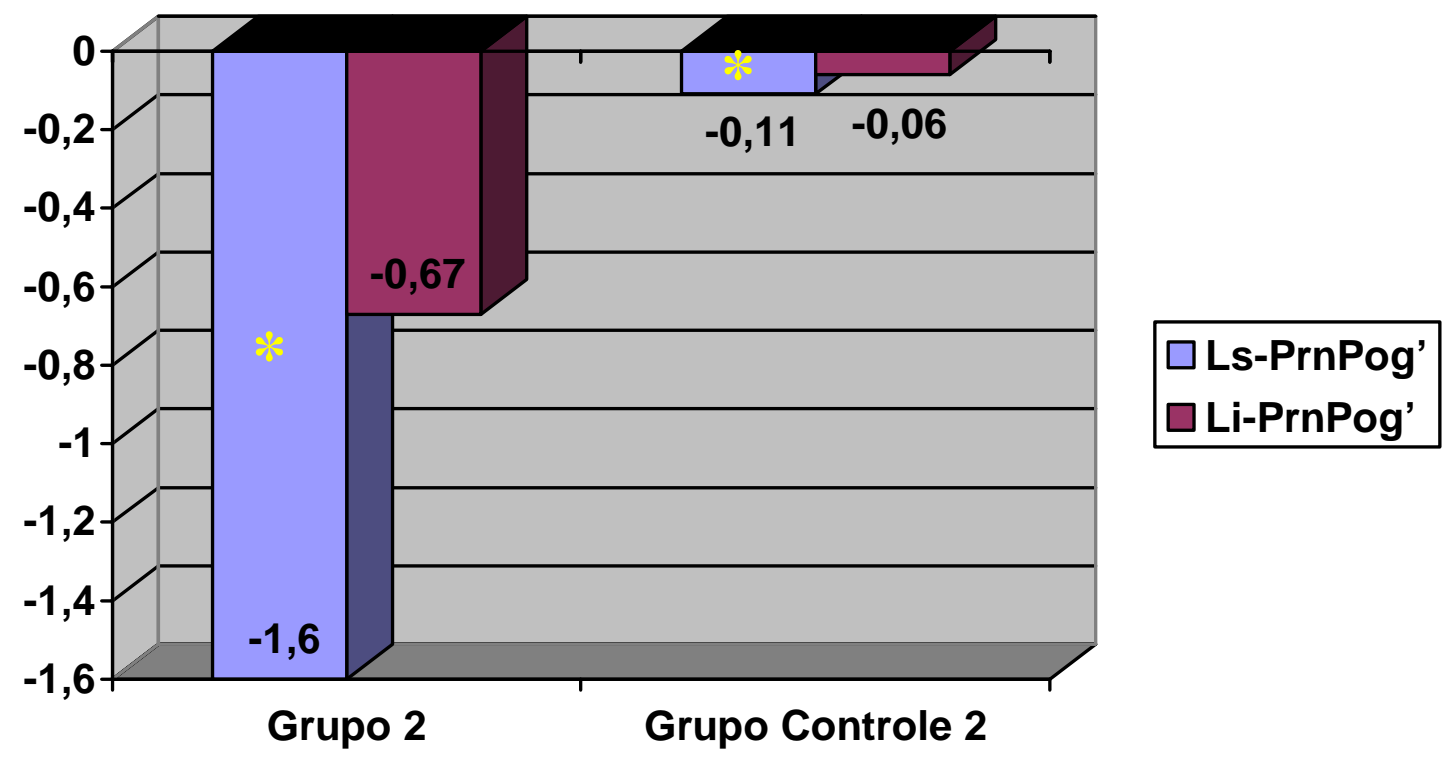

FIGURA 37 - Componente Tegumentar (mm) - Ls-PrnPog'; Li-PrnPog' 
6- DISCUSSÃO 
A má oclusão de Classe II constitui um dos assuntos mais estudados e polêmicos, na Ortodontia, em função de sua pobre repercussão estético-funcional, o que justifica a grande incidência nas clínicas ortodônticas de pacientes que a apresentam e que requerem um tratamento apropriado ${ }^{29}$. Como assegurado por diversos autores ${ }^{7,8,29,36,57,100}$, essa discrepância ântero-posterior denota uma variabilidade muito grande de apresentações, envolvendo componentes esqueléticos e dentários e que, dependendo de sua quantidade e interação com o tecido mole, acabam por afetar, adicionalmente, a imagem e auto-estima dos pacientes.

Considerando-se as inúmeras variações dentofaciais que essa má oclusão exibe, assume-se conseqüentemente que o tratamento também deva ser diferenciado. Atualmente, com a disponibilidade de numerosos recursos, a maioria dos clínicos tende a escolher um protocolo de tratamento baseado na região do esqueleto craniofacial em que eles acreditam que o aparelho melhor influenciará ${ }^{29}$. Por exemplo, quando a má oclusão é caracterizada principalmente por uma relação posterior da mandíbula com a base do crânio ${ }^{7}$, dá-se preferência pela instituição de aparelhos ortopédicos funcionais que se concentram na estimulação do crescimento mandibular, embora ainda exista um desacordo quanto à real eficácia desse procedimento ${ }^{55}$. Uma outra variação de tratamento para a eliminação da convexidade facial, presente nas más oclusões de Classe II, é a aplicação de forças extrabucais sobre o arco dentário superior, redirecionando ou mesmo restringindo o movimento para frente e para baixo da maxila, bem como inibindo o desenvolvimento normal dos primeiros molares superiores.

Apesar da disponibilidade de diferentes aparelhos para a promoção de modificações no crescimento craniofacial, comparando-se com a diversidade morfológica da má oclusão que eles se propõem a corrigir, ainda é difícil concluir, nos tempos hodiernos, se esta diversidade reflete indicações específicas para cada aparelho e se cada aparelho realmente demonstra efeitos próprios e consistentemente superiores aos demais. Com a intenção de esclarecer e orientar melhor o clínico durante as instituições terapêuticas, a avaliação e a comparação dos 
efeitos dento-esqueléticos promovidos por diferentes aparelhos, com particularidades em seus mecanismos de ação, vêm sendo abordadas na literatura. Como exemplo de comparação dos efeitos sobre o crescimento craniofacial de um aparelho ortopédico funcional com um aparelho ortopédico mecânico, citam-se o estudo de $\mathrm{MEACH}^{108}$ e o de $\mathrm{JAKOBSSON}^{84}$, que utilizaram pacientes tratados com o aparelho Ativador e pacientes tratados com o aparelho Extrabucal de tração cervical. Uma outra categoria de comparação pode ser exemplificada pelo trabalho de HAYDAR; ÜNER ${ }^{71}$ que compararam os efeitos dento-alveolares e esqueléticos de um sistema de força intrabucal (Jones Jig) com um sistema de força extrabucal (aparelho Extrabucal de tração cervical). BURKHARDT; McNAMARA JÚNIOR; BACCETTI ${ }^{29}$, também compararam detalhadamente os efeitos do tratamento das más oclusões de Classe II entre um aparelho de ortopedia funcional fixo (aparelho de Herbst) com um aparelho distalizador de molar (Pêndulo).

Esses exemplos de estudos científicos, aliados ao diminuto número de publicações comparando tratamentos de más oclusões de Classe II que estimulam o crescimento mandibular e aqueles que restringem o crescimento maxilar, contribuíram para a realização da atual pesquisa. Os efeitos dento-esqueléticos promovidos pela utilização do aparelho de Herbst, classificado dentro da ortopedia funcional fixa, que não depende da colaboração direta do paciente, que o tem tornado popular durante as últimas décadas, e os efeitos promovidos pelo aparelho Extrabucal de tração occipital, classificado dentro da ortopedia mecânica, que, por outro lado, depende da compreensão e da cooperação direta por parte do paciente, foram avaliados. A escolha dessas duas modalidades terapêuticas, associada aos fatores prévios, deu-se principalmente pela inexistência de comprovações científicas quanto aos possíveis efeitos similares no complexo maxilar ditos, incessantemente, na literatura. 


\subsection{Aspectos da amostra}

\subsubsection{Grupos Experimentais}

Como todos os pacientes de ambos os grupos experimentais foram tratados de modo específico, com o objetivo de estudá-los posteriormente, este estudo se caracteriza como prospectivo, pois anterior à instituição das terapias, estabeleceram-se os protocolos dos tratamentos e o número mínimo pretendido de pacientes necessários para a realização da análise estatística. Os grupos experimentais se enquadram dentro de uma amostra prospectiva longitudinal, composta por pacientes com más oclusões de Classe II, divisão 1 , tratados com aparelhos ortopédicos, avaliados cefalometricamente ao início e ao final dos tratamentos.

\section{- Grupo 1}

Nos últimos tempos, o grande interesse clínico e científico pelo aparelho de Herbst, nas correções das más oclusões de Classe II de Angle que apresentam sinais clínicos e cefalométricos de deficiência mandibular, contribuiu para o desenvolvimento de vários sistemas de inserção deste mecanismo nos arcos dentários. Os desenhos deste aparelho ortopédico funcional têm-se tornado cada vez melhores e mais sofisticados, superando suas limitações e fornecendo aplicações multifuncionais baseadas no planejamento do tratamento ${ }^{79,99,114,132,200}$.

Dentre as variações encontradas deste aparelho, este estudo preconizou apenas a utilização do aparelho de Herbst com cantiléver, com poucos estudos na literatura que o tem avaliado quanto aos efeitos dento-esqueléticos ${ }^{29}$. Dentre as características e as vantagens proporcionadas por este aparelho, destacam-se: a fácil adaptação e boa retenção das coroas de aço; constituintes metálicos resistentes às quebras e pouco intrusivos, mantendo a integridade dos tecidos moles; pouca interferência na estética e na função tendo fácil aceitação por parte do paciente; permitir ao paciente comer com conforto e realizar normalmente os procedimentos de higiene; e aplicação de forças contínuas e bem direcionadas visto que não há partes removíveis, contribuindo com uma maior previsibilidade do tempo de tratamento e 
dos resultados. Como desvantagem clínica, cita-se uma possível irritação na bochecha do paciente, principalmente nos mais novos (sete a nove anos), em virtude do espesso mecanismo por vestibular ${ }^{112,114,116 .}$

No tocante à época de tratamento da deficiência mandibular com o aparelho de Herbst, a literatura exibe condutas bastante diversificadas, elegendo as vantagens e as desvantagens de cada período de instalação (fase da dentadura decídua, mista e permanente), para justificar os períodos de intervenção ${ }^{6}$. PANCHERZ ${ }^{129,131}$ indica o tratamento ortopédico funcional fixo na dentadura permanente ou logo após o pico de crescimento pubescente (entre 14 e 16 anos para o gênero masculino e entre 12 e 14 anos para o feminino), não recomendando um tratamento precoce nas dentaduras decídua ou mista, alegando nestes últimos casos um difícil alcance de uma intercuspidação estável após a terapia, prolongando-se o tempo de contenção. De acordo com PANCHERZ; HÄGG ${ }^{137}$, o aparelho de Herbst é melhor empregado em período de pico de crescimento ou logo após, não devendo ser iniciado em pacientes que já tenham ultrapassado esta fase, pois as alterações esqueléticas seriam mínimas e os efeitos maiores do tratamento seriam confinados na área dento-alveolar. Por outro lado, PFEIFFER; GROBÉRTY ${ }^{146}$ preconizam o início do tratamento durante a dentadura mista tardia, ao redor dos 10,5 anos para o gênero feminino e 11,5 anos para o masculino, alegando ser esse período suficiente para a concretização de alterações ortopédicas e ortodônticas, devendo ser finalizado durante a fase de maior crescimento.

De acordo com a literatura, a consideração da idade óssea, evidenciando o estágio de crescimento e desenvolvimento em que o indivíduo se encontra, se faz necessária nos planejamentos dos tratamentos ortopédicos, principalmente quanto à identificação do período máximo de crescimento pubescente ${ }^{184}$. Os clínicos têm realizado uma avaliação mais rotineira da maturidade óssea dos pacientes, pela análise de radiografias carpais ou mesmo pela averiguação da estatura dos pacientes nos próprios consultórios odontológicos. De acordo com TAVANO ${ }^{184}$, há íntima relação entre a maturação óssea e a velocidade de crescimento estatural e craniofacial. A taxa máxima de crescimento facial ocorre na mesma época ou logo após o ponto máximo de velocidade de crescimento estatural, havendo uma semelhança nos tempos de ocorrência. Outros autores também reportaram em seus 
trabalhos a íntima associação entre o pico de crescimento em altura e certos estágios de desenvolvimento esquelético da mão e punho, além da intima relação entre o pico de crescimento estatural e a dimensão facial ${ }^{63,64}$. HÄGG; TARANGER $^{63,64}$ descreveram alguns importantes indicadores do surto de crescimento pubescente, que, dentre eles podem-se citar: a média de idade em que o surto de crescimento se inicia é de 10 anos para o gênero feminino e de 12 anos para o masculino; para ambos os gêneros, o pico de crescimento ocorre em torno de dois anos após o início do surto de crescimento e a sua finalização ocorre aos 15 anos em média para o gênero feminino e aos 17 anos para o masculino; se o osso sesamóide não se mostra ossificado, significa que o pico de velocidade em altura ainda não foi alcançado e se, por outro lado, esse osso é visível, em estágios iniciais, significa que a maioria dos pacientes se encontra em período de aceleração do surto de crescimento pubescente; a menarca ocorreu em média 1,1 anos após o pico de crescimento e a mudança de voz em 1,8 anos após o início do surto de crescimento.

O período de máximo crescimento pubescente, segundo HÄGG; TARANGER ${ }^{63}$ é um período muito vantajoso para os tratamentos ortopédicos, pois a contribuição esquelética na alteração da relação dentária de Classe II para uma relação de Classe I é maior quando o paciente é tratado nessa fase ${ }^{59,117}$. WOODSIDE ${ }^{207}$ considera a identificação do período de crescimento pré-pubescente o fato mais relevante no auxílio de tratamentos com aparelhos funcionais e aconselha a instituição do tratamento na época de aceleração desse crescimento. CROFT; BUSCHANG; ENGLISH; MEYER ${ }^{39}$ alegam que a decisão da época de tratamento a mantém como parte crítica nos planejamentos ortodônticos, precisando ser efetuada, principalmente, em bases individuais, já que a idade em que o pico de crescimento se instala varia muito entre os pacientes.

No atual estudo, não se avaliaram as idades ósseas dos pacientes, o que de certa forma ressalta uma deficiência de planejamento científico. Logo, não foi possível averiguar com precisão o estágio de crescimento e desenvolvimento em que os pacientes experimentais se encontravam durante o período ativo de tratamento. $A$ idade cronológica inicial (média de 12,01 anos) e o estágio de desenvolvimento oclusal (maioria dos pacientes enquadrada na fase inicial de dentadura permanente) foram os parâmetros levados em consideração. 
A média do tempo de tratamento real com o aparelho de Herbst se deu em um ano, o que a diferencia de alguns estudos que o utilizaram por tempo médio de seis a sete meses ${ }^{66,83,110,124,126,127,133,137,139,140,144,166,167}$. Contudo, a duração do tratamento ainda é controversa na literatura, pois alguns autores, como PFEIFFER; GROBÉRTY ${ }^{146}$ salientam que essa deva ser o suficiente para a instalação e manutenção das alterações ortopédicas, que normalmente requer um tempo mínimo de 12 meses. Embora alguns estudos tenham utilizado o aparelho de Herbst por período menor de tempo, a utilização de contenção pós-tratamento se fez presente na sua maioria com o aparelho Ativador, instituído por um tempo médio de dois $\operatorname{anos}^{40}$, no afã de se manterem os resultados a longo prazo ${ }^{128}$.

É importante relembrar que a obtenção da média do tempo de tratamento deste estudo foi baseada nas datas fornecidas pelas documentações ortodônticas, o que pode não ter seguido fielmente o tempo de tratamento real de cada paciente, pela dificuldade em se obter de imediato as telerradiografias no final do período terapêutico dos pacientes da pesquisa.

\section{- Grupo 2}

Os diferentes tipos do aparelho Extrabucal quando corretamente indicados e utilizados podem proporcionar grandes benefícios aos pacientes, incluindo uma movimentação ortodôntica fisiológica com mínimo desconforto e prejuízo tecidual $^{73,119}$. Mesmo possibilitando alterações ortopédicas e ortodônticas, a grande desvantagem deste método de tratamento ainda é a falta de cooperação por parte do paciente, como também o risco do paciente sofrer injúrias ao utilizá-lo ${ }^{71}$.

A tração occipital foi a tração de escolha deste estudo para se verificar, principalmente no complexo maxilar, as alterações induzidas por ela que são referenciadas freqüentemente na literatura como alterações similares quando da utilização do aparelho de Herbst ${ }^{127,129,134,138,142}$. Para tanto, selecionaram-se pacientes que apresentassem aspectos clínicos e cefalométricos parecidos aos pacientes submetidos à ortopedia fixa, associados a uma característica facial 
equilibrada ou ligeiramente mais expressiva no sentido vertical, mesmo que as forças extrabucais sejam mais indicadas em casos de protrusão maxilar ${ }^{146}$.

Um fator importante a ser considerado na instituição dos aparelhos Extrabucais é o padrão craniofacial original do paciente ${ }^{74}$. Pacientes que apresentam um padrão de crescimento desfavorável necessitam de maior controle sobre os vetores de força aplicados, principalmente no sentido vertical. Logo, se o crescimento do paciente é considerado adequado ou excessivo, deve-se indicar a tração occipital para a restrição do desenvolvimento vertical, já que esse tipo de tração intrui ou mesmo impede o desenvolvimento normal dos molares superiores , $^{40,27,54,58,146}$. A extrusão do molar, em pacientes meso ou dolicofaciais, pode causar uma rotação da mandíbula para inferior e para posterior com um aumento concomitante na altura facial e, conseqüentemente, piorar a má oclusão ${ }^{18,54}$. Por outro lado, o aparelho Extrabucal de tração cervical é indicado no tratamento de pacientes com padrões faciais que exibem uma deficiência do crescimento vertical, um ângulo do plano mandibular diminuído e sobremordida. Nesses casos, a extrusão dos molares superiores, a inclinação para baixo e para trás da maxila e da mandíbula e o aumento na dimensão vertical são desejáveis como objetivos de tratamento ${ }^{4,9,10,14,16,27,49,58,146}$.

Para a instituição dos diferentes vetores de força do aparelho Extrabucal, os clínicos precisam adquirir um conhecimento básico sobre os seus princípios biomecânicos, pois o monitoramento dos sistemas de forças é um pré-requisito na obtenção de movimentos dentários controlados ${ }^{4,58}$. De acordo com GREENSPAN ${ }^{58}$ e ARMSTRONG ${ }^{4}$ a direção da força varia com o tipo de tração extrabucal e também com a angulação e com o comprimento do braço externo do arco facial, sendo essas considerações baseadas no centro de rotação dos molares superiores e da maxila. Esses aspectos mecânicos, em estudos científicos precisos, se fazem necessários para o entendimento das alterações dento-esqueléticas ${ }^{49}$.

A magnitude de força também influencia as respostas do tratamento com o aparelho Extrabucal, havendo uma correlação entre esta variável e os efeitos obtidos no complexo craniofacial ${ }^{204,205}$. Mesmo não havendo ainda uma precisa relação entre a magnitude de força e as respostas dento-esqueléticas ${ }^{15}$, de forma geral, 
preconizam-se forças de intensidade maior (600 - 1400 gramas) para a obtenção de movimentos ortopédicos e forças de intensidade menor (< 600 gramas) para a obtenção de movimentos ortodônticos ou mesmo movimentos ortopédicos mais lentos $^{9,198}$. De acordo com alguns estudos em animais de laboratório, as forças extrabucais são capazes de alterar a morfologia sutural e o relacionamento espacial da maxila 24,109 .

A duração de força, considerada intermitente, com a utilização das trações extrabucais $^{171}$, também faz parte das variáveis que influenciam os resultados com o uso dos aparelhos Extrabucais. Segundo ARMSTRONG ${ }^{4}$, o controle da direção, da magnitude e da duração da força é indispensável para a obtenção de excelentes resultados com esta forma de terapia mecano-ortopédica.

Estas considerações referidas acima auxiliam na interpretação dos resultados deste estudo, pois a instalação do aparelho Extrabucal nos pacientes do grupo 2 seguiu um protocolo único de tratamento: todos os componentes receberam uma força de direção occipital (passando pelo centro de resistência dos molares superiores), de média magnitude (400 gramas) e intermitente. A avaliação da maturidade óssea dos componentes, mais uma vez, não foi efetuada, seguindo apenas a idade cronológica (idade inicial média de 10,28 anos dos pacientes ao se instalarem os aparelhos) e o desenvolvimento oclusal como parâmetros de análise. A idade de instituição, de forma geral, concorda com a literatura para a obtenção de bons resultados, tanto ortodônticos como ortopédicos ${ }^{57}$.

\subsubsection{Grupos Controles}

Sabe-se da importância em se utilizar grupos controles em trabalhos científicos, comparando-se os efeitos de diferentes aparelhos, uma vez que a simples comparação entre pacientes tratados não distingue entre as alterações provocadas unicamente por crescimento e/ou tratamento. Os profissionais que lidam com o crescimento craniofacial, têm que ter em mente que algumas das alterações observadas com a aplicação de certas terapias, nem sempre são derivadas de suas ações mecânicas ou funcionais, mas sim do próprio crescimento. Adicionalmente, a 
possibilidade de comparação das alterações provocadas exclusivamente pelo crescimento $^{38,143,178}$ (grupo controle) com as alterações provocadas pelo crescimento associado ao tratamento ${ }^{85,155}$ (grupo experimental), pelo mesmo período de tempo, permite-nos verificar se os efeitos terapêuticos são suficientes para produzir modificações significantes nos relacionamentos esqueléticos e dentários dos pacientes.

A escassez de grupos controles, compostos por pacientes com más oclusões de Classe II, em estudos que os solicitam, está em relação direta com a dificuldade em se realizar acompanhamentos periódicos desses tipos de pacientes por tempo prolongado, ainda que seja considerado anti-ético, nos dias atuais, não tratá-los. Perante esta realidade científica, este estudo, no intuito de enriquecer-se, utilizou documentações fidedignas de pacientes de origem caucasiana, com más oclusões de Classe II, divisão 1 não tratados ortodonticamente, pertencentes ao arquivo de documentações denominado Burlington Growth Centre, localizado na Faculdade de Odontologia da Universidade de Toronto, Canadá ${ }^{48,70,147,149,187}$. A seriedade com que se planejou e se estabeleceu esse centro de crescimento, leva o seu nome em caráter mundial juntamente com outros centros famosos como Oregon, Denver, Michigan e Bolton ${ }^{17}$, sendo referenciado em inúmeros estudos dentro da Ortodontia e Ortopedia Funcional que o requerem $37,69,85,86,91,101,186$.

Com o objetivo de se parearem as idades dos grupos controles com os grupos experimentais, ao se avaliarem as documentações ortodônticas pertencentes ao arquivo de documentações Burlington Growth Centre, de más oclusões de Classe II, divisão 1 não tratadas, pôde-se selecionar apenas 20 pacientes para comporem o grupo controle 1, mediante a disponibilidade de telerradiografias de aspecto longitudinal, aos 12 e aos 14 anos de idade. Por outro lado, para compor o grupo controle 2, preferiram-se as telerradiografias aos nove e aos 12 anos às telerradiografias aos 10 e aos 12 anos, pela grande disponibilidade de documentações nessa idade inicial de observação, possibilitando a constituição de 31 pacientes. Uma vez que as idades iniciais diferiam entre o grupo 2 e o grupo controle 2, reajustaram-se todas as medidas cefalométricas pertencentes aos pacientes do grupo controle 2, propiciando uma comparação estatística intergrupos mais confiável. A dificuldade em se parearem os grupos experimentais com os 
grupos controles em vários estudos científicos, desde há muitos anos, fez com que os pesquisadores já lançassem mão de artifícios para possibilitar a comparação estatística $^{97}$.

Os dados provenientes da comparação intergrupos na fase prétratamento, visualizados pelas tabelas 2 e 6, evidenciaram que os grupos controles não se mostraram totalmente similares aos grupos experimentais quanto às suas características dento-esqueléticas. Contudo, decidiu-se incluí-los nesta pesquisa para a avaliação do impacto dos tratamentos preconizados no crescimento craniofacial, pois os efeitos de um tratamento são melhores avaliados se as mudanças num grupo controle forem consideradas e a significância do tratamento documentada. Presume-se que essas diferenças de valores tiveram um efeito mínimo nos achados cefalométricos e na interpretação dos resultados deste estudo.

As variáveis discrepantes, dentro de alguns componentes de análise, refletem de certa forma, a dificuldade de aquisição de pacientes controles dentro de um espectro limitado de opções. Adicionalmente, essas diferenças reforçam a idéia de multiplicidade de possíveis arranjos esqueléticos e dentários verificados nos pacientes apresentando a má oclusão de Classe II $^{113}$.

\subsection{Aspectos da metodologia}

A técnica de estudo cefalométrico, introduzida há décadas atrás $^{26,56,69,88,148,182}$, foi o método de escolha deste estudo para a avaliação das alterações dento-esqueléticas decorrentes das opções de tratamento aplicadas nas correções das Classes II. As radiografias, mais especificamente as telerradiografias, ainda são ferramentas potentes e indispensáveis na rotina ortodôntica ${ }^{16}$, sendo constantemente utilizadas no diagnóstico, no planejamento e na avaliação final dos resultados obtidos. Preferiu-se a análise cefalométrica computadorizada, por ser um método eficiente, rápido, economizando tempo de trabalho, além de sua universalização entre os profissionais da área e nos centros de documentações radiológicos ${ }^{41,95,158,198}$. 
Como as medidas cefalométricas são instrumentos insubstituíveis nas pesquisas ortodônticas, se faz necessário, conseqüentemente, realizar o erro metodológico nos trabalhos científicos justamente para proporcionar maior confiabilidade dos dados obtidos. BAUMRIND; FRANTZ ${ }^{12,13}$, já em 1971, afirmaram que, com a repetição da identificação dos pontos cefalométricos, a magnitude dos erros é muito grande para ser desprezada e extremamente variável entre os diferentes pontos considerados.

Conduziu-se a análise estatística em todos os grupos da amostra e entre os grupos experimentais e os seus respectivos grupos controles, aferindo as alterações decorrentes dos tratamentos e do crescimento craniofacial. Devido ao número diferente entre os componentes do gênero masculino e do feminino, compondo os quatro grupos, não se avaliaram as diferenças entre os gêneros, aliado ao fato de que esta análise não foi proposta do estudo.

As alterações dento-esqueléticas compreenderam o foco principal das análises deste estudo. Entretanto, três mensurações do componente tegumentar foram incorporadas com o interesse em se verificar os possíveis efeitos dos tratamentos sobre o tecido mole.

\subsection{Interpretação e discussão dos resultados}

A interpretação e discussão dos resultados se concentrarão nas alterações dento-esqueléticas encontradas na comparação entre os grupos experimentais e os grupos controles, visando a estabelecer os efeitos promovidos pelos aparelhos sobre o crescimento craniofacial nos diferentes componentes de análise. 


\subsubsection{Tratamento com o aparelho de Herbst com cantiléver}

\section{Componente Maxilar}

$\mathrm{Na}$ comparação estatística entre as alterações do tratamento com 0 aparelho de Herbst e as alterações do grupo controle 1, revela-se que as variáveis do componente maxilar não se alteraram estatisticamente de modo significante. Verificase que o tratamento não induziu repercussões intensas sobre o crescimento da maxila, presumindo-se que a força retrusiva (direcionada para a posterior) empregue pelo mecanismo telescópico sobre este osso basal não seja o suficiente para restringir o seu crescimento. Logo, o aumento do comprimento efetivo seguiu os parâmetros convencionais constatados em pacientes que apresentam oclusões normais ou más oclusões de Classe II quando não submetidos às terapias ortodônticas $^{98,155,156,159}$, e, concordando com trabalhos prévios ${ }^{61,83,134,179}$, a sua posição relativa no sentido ântero-posterior em relação à base craniana apresentou uma suave tendência, mesmo não sendo significante, em se tornar mais protruída com o crescimento.

O resultado deste estudo, por outro lado, discorda com o resultado dos trabalhos de PANCHERZ ${ }^{124,127,129}$, VALANT; SINCLAIR ${ }^{194}$, PANCHERZ; FACKEL $^{136}$, MCNAMARA JÚNIOR; HOWE; DISCHINGER ${ }^{106}$, HÄGG $^{59}$, LAI; MCNAMARA JÚNIOR $^{92}$, pois esses autores encontraram uma restrição do crescimento maxilar. Esta divergência de dados pode estar embasada nos diversos tipos metodológicos de pesquisa com o emprego do aparelho de Herbst, devendo ser considerado, por exemplo, o tipo de inserção e de ancoragem do aparelho que os estudos preconizaram.

\section{Componente Mandibular}

$\mathrm{Na}$ comparação estatística entre as alterações do tratamento com 0 aparelho de Herbst e as alterações do grupo controle 1, revela-se que apenas a variável S.N.B do componente mandibular se alterou estatisticamente de modo 
significante enquanto que a variável Co-Gn não se alterou de modo significante. Verifica-se que o tratamento não induziu repercussões intensas sobre o crescimento da mandíbula, pois o aumento de $1,42^{\circ}$ da posição relativa no sentido ânteroposterior da mandíbula em relação à base craniana não necessariamente resultou de um aumento do crescimento mandibular sagital. A grande vestibularização dos incisivos inferiores com o tratamento pode ter influenciado a localização do ponto $B$, anteriorizando-o, pois é sabido que esse ponto cefalométrico é passível de remodelação ${ }^{100}$. Adicionalmente, o resultado geral do componente mandibular pode estar relacionado a uma remodelação óssea mais proeminente na fossa glenóide, nos pacientes submetidos à terapia, do que propriamente no côndilo mandibular. Estudos conduzidos em humanos e em animais indicam que uma porção considerável da alteração ortopédica desenvolvida com o aparelho de Herbst esteja relacionada à migração anterior da fossa glenóide ${ }^{138,207}$.

A quantidade de crescimento mandibular induzido pelo aparelho de Herbst está na dependência de vários fatores. Dentre eles, a idade no início do tratamento e o tipo de reativação do aparelho ${ }^{180,205}$. É possível que se encontrem diferenças quanto ao efeito do tratamento nos diversos estudos, pois nem sempre esses fatores são coincidentes nas metodologias.

\section{Idade no início do tratamento}

Como a idade óssea, baseada nos estágios de ossificação dos ossos carpais ou na averiguação da estatura, não foi avaliada nos pacientes deste estudo, deixa-se em aberto uma possibilidade de o tratamento ter sido instituído em pacientes que não vivenciavam o surto de crescimento pubescente ${ }^{137,170}$. Baseado em estudos científicos anteriores, nesta situação a remodelação óssea é mais evidente na fossa glenóide do que no côndilo mandibular ${ }^{209}$.

Deve-se considerar também que a variabilidade individual é muito grande, quanto à intensidade de crescimento condilar, para ser desconsiderada na interpretação de resultados científicos ${ }^{20}$. O potencial genético dos indivíduos, mesmo sendo contestada nos dias atuais por aqueles que acreditam que a mandíbula esteja 
na dependência de estímulos epigenéticos locais ${ }^{103}$, ainda é julgada a ser um fator importante na pré-determinação do crescimento mandibular ${ }^{200}$.

\section{Reativação do aparelho}

A constante reativação do aparelho ( 1 a $2 \mathrm{~mm}$ a cada dois meses), o que a diferencia do avanço único realizado nos pacientes desta pesquisa, pode ser um fator importante na obtenção de maior crescimento condilar ${ }^{44}$. Mesmo não podendo aplicar na íntegra para humanos os resultados de experimentos em animais de laboratório ${ }^{107,145}$, acredita-se, baseado em estudos com macacos, que o avanço gradual da mandíbula aumente a velocidade e a quantidade do crescimento da cartilagem condilar, sendo este procedimento o melhor na produção do aumento ortopédico do comprimento mandibular ${ }^{46,153,196,197}$. Como a ação mecânica intermitente também favorece a aposição óssea na fossa glenóide, dá-se suporte ao conceito de uma ação de bombeamento metabólica dos tecidos retrodiscais, resultando no aumento do suprimento sangüíneo nos tecidos circundantes ${ }^{207}$.

\section{Considerações gerais}

RUF; PANCHERZ ${ }^{51}$ contestaram FRÄNKEL ${ }^{51,52}$ por ele não acreditar que o aumento no comprimento do corpo mandibular possa ser alcançado por estimular o sítio de crescimento condilar com os aparelhos ortopédicos funcionais. Entretanto, os primeiros autores, embasados cientificamente, alegam que o deslocamento mecânico da mandíbula resulta sim em um crescimento condilar aumentado, considerando este esforço ortopédico um excelente artifício na correção das más oclusões com retrognatismo mandibular, auxiliado ao fato de que o centro primário de crescimento da mandíbula se localiza nos côndilos ${ }^{11,21,34,36,208}$. McNAMARA JÚNIOR; CARLSON ${ }^{104}$ alegam também que o aumento na espessura da cartilagem condilar possa ser um fenômeno temporário, não resultando em um aumento permanente do comprimento mandibular ${ }^{183}$. Pelo tempo de duração do tratamento com o aparelho de Herbst neste estudo, deduz-se que os pacientes possam ter desenvolvido este fenômeno. 
Quanto ao deslocamento mecânico proporcionado pelos aparelhos ortopédicos funcionais, protruindo a mandíbula, vários estudos demonstraram, ao se avaliar a articulação temporomandibular, que o relacionamento normal côndilo-fossa é restaurado no final do período experimental ${ }^{39,134}$. Mesmo que os pacientes deste estudo tenham sofrido uma protrusão mandibular com o aparelho, descarta-se a possibilidade de uma mudança posicional do côndilo em sentido anterior, em relação à fossa mandibular, com a terapia.

Utilizaram-se duas medidas cefalométricas no presente estudo para analisar os efeitos no componente mandibular. Talvez a adição de outras medidas cefalométricas da mandíbula refletisse melhor o seu comportamento no sentido sagital $^{84,117}$.

\section{Relação Maxilomandibular}

$\mathrm{Na}$ comparação estatística entre as alterações do tratamento com 0 aparelho de Herbst e as alterações do grupo controle 1, revela-se que apenas a variável A.N.B se alterou estatisticamente de modo significante enquanto que a variável N.A.Pog não se alterou de modo significante. Verifica-se que a mecânica do aparelho de Herbst diminuiu o grau de discrepância maxilomandibular, o que é relatado na literatura ${ }^{39,66,83,179}$, enquanto que a convexidade facial não sofreu grandes repercussões com esta terapia.

Baseado nas discussões preliminares, referentes aos componentes maxilar e mandibular, fica evidente que a melhora da discrepância maxilomandibular se procedeu, principalmente, de alterações dentárias, pois o aparelho de Herbst não induziu grandes alterações nos ossos basais e, conseqüentemente, na convexidade facial. A protrusão dos incisivos inferiores é, com certeza, um fator de grande peso na relação angular entre os pontos $\mathrm{A}$ e $\mathrm{B}$. 


\section{Componente Vertical}

$\mathrm{Na}$ comparação estatística entre as alterações do tratamento com 0 aparelho de Herbst e as alterações do grupo controle 1, revela-se que apenas a variável PoOr.PO se alterou estatisticamente de modo significante enquanto que as demais não se alteraram de modo significante. Verifica-se que o tratamento, de modo geral, não influenciou o padrão de crescimento craniofacial dos pacientes, o que também é relatado na literatura ${ }^{165,176,189,191}$. O plano mandibular se deslocou paralelamente entre os pacientes tratados com o aparelho de Herbst e os pacientes do grupo controle, indicando um crescimento harmonioso entre as regiões anterior e posterior da face.

O aumento médio do ângulo do plano oclusal em $2,90^{\circ}$ mostra uma rotação ântero-inferior do plano oclusal devido, principalmente, à influência da mecânica do aparelho sobre os dentes póstero-superiores no sentido vertical. Este achado é substanciado na literatura ${ }^{92,99,106,129,134,140}$, pois se confirma a suposta ação "extrabucal" do aparelho de Herbst sobre esses dentes. Como o mecanismo telescópico direciona uma força para a superior na região posterior da maxila, restringe-se, conseqüentemente, o desenvolvimento normal para baixo dos molares superiores.

É importante lembrar que o plano oclusal desta pesquisa envolveu na sua constituição os dentes anteriores. As alterações nas inclinações dentárias e a intrusão dos incisivos inferiores com a mecanoterapia podem ter contribuído para a rotação deste plano ${ }^{1,92}$.

Adicionalmente, o aparelho de Herbst parece apresentar um efeito rotacional sobre o osso maxilar. A rotação do plano palatino no sentido horário, mesmo não sendo estatisticamente significante, reflete a criação de um momento (potencial ou tendência de rotação) em decorrência da linha de ação da força liberada pelo mecanismo telescópico, que se direciona para cima e para trás, passar abaixo do centro de resistência da maxila. Esta característica também embasa as publicações literárias, que comparam o aparelho de Herbst ao aparelho Extrabucal de tração occipital ${ }^{92,134}$. 


\section{Componente Dento-alveolar Superior}

$\mathrm{Na}$ comparação estatística entre as alterações do tratamento com 0 aparelho de Herbst e as alterações do grupo controle 1, revela-se que as variáveis 1.NA, 1-NA, 1.PP, ‥PP, $\underline{6}-\mathrm{PP}$ se alteraram estatisticamente de modo significante enquanto que 1 -PP, 1 -SPerpPO e $\underline{6}-S P e r p P O$ não se alteraram de modo significante. Verifica-se que o mecanismo telescópico lingualizou e retruiu os incisivos superiores, bem como inclinou os molares superiores para a distal e restringiu o seu crescimento no sentido vertical. Essas alterações dentárias promovidas durante a terapia com o aparelho de Herbst se relacionaram intimamente com o sistema de forças que esse aparelho liberou sobre o arco dentário superior.

\section{Molares superiores}

A liberação da força pelo aparelho para superior e para posterior sobre o arco dentário superior resultou na restrição do desenvolvimento normal dos molares superiores $^{32}$ no sentido vertical e na inclinação para a distal dos mesmos. Essas reações dentárias evidenciam a íntima relação dos molares superiores com o sistema de inserção do aparelho, pois são esses dentes os pilares de apoio do sistema telescópico com cantiléver, utilizado neste estudo. A inclinação para a distal reflete a criação de um momento (potencial ou tendência de rotação) em decorrência da linha de ação da força produzida pelo sistema telescópico passar abaixo do centro de resistência dos molares, enquanto que a restrição no sentido vertical dos molares é atribuída ao próprio sentido (para superior) de liberação da força pelo aparelho.

Os resultados obtidos deste estudo não evidenciam a ocorrência de distalização, nem mesmo de intrusão real dos molares superiores, o que é relatado com freqüência na literatura $40,50,83,89,92,99,126,127,129,130,131,134,145,194$. Contudo, estes achados concordam com as publicações que assimilam o aparelho de Herbst ao aparelho Extrabucal de tração occipital, quanto ao efeito de restrição do desenvolvimento no sentido vertical dos molares superiores ${ }^{99,142,200}$. 
O comportamento de lingualização e retrusão dos incisivos superiores pressupõem um efeito compensatório do resultado ortodôntico promovido pelo aparelho, principalmente na região dos molares, podendo estar relacionado também às alterações oclusais e funcionais da musculatura peribucal. Estes resultados concordam com diversos autores ${ }^{99,138,140,180,189}$.

\section{Componente Dento-alveolar Inferior}

$\mathrm{Na}$ comparação estatística entre as alterações do tratamento com 0 aparelho de Herbst e as alterações do grupo controle 1, revela-se que as variáveis $\overline{1}$.NB, $\overline{1}-\mathrm{NB}, \overline{1}$.GoMe, $\overline{1}$-GoMe, $\overline{6}$.GoMe, $\overline{1}$-SPerpPO e $\overline{6}$-SPerpPO se alteraram estatisticamente de modo significante enquanto que apenas a variável $\overline{6}$-GoMe não se alterou de modo significante. Verifica-se que o mecanismo telescópico vestibularizou, protruiu e intruiu os incisivos inferiores, bem como mesializou e inclinou para a mesial os molares inferiores. Essas alterações dentárias promovidas durante a terapia com o aparelho de Herbst se relacionaram intimamente com o sistema de forças que este aparelho liberou sobre o arco dentário inferior e refletiram, principalmente, a perda substancial de ancoragem dentária ${ }^{65,132}$ em decorrência do tipo de aparelho e de ancoragem utilizado e da insuficiência de um crescimento mandibular adicional desenvolvida pelos pacientes tratados ${ }^{62}$. Resumidamente, as alterações dentárias no tratamento com o aparelho de Herbst foram basicamente resultados da perda de ancoragem, mesializando os molares inferiores e vestibularizando os inferiores ${ }^{138,140}$.

\section{Molares inferiores}

O aparelho de Herbst com cantiléver, por ser inserido sobre os molares inferiores, acaba por desencadear grandes repercussões ortodônticas sobre esses dentes. Com a liberação da força, em sentido anterior, pelo mecanismo telescópico, os molares responderam, conseqüentemente, com uma grande mesialização e inclinação mesial ${ }^{106,126,127,134,144,168,194}$. Este resultado evidentemente é positivo para a 
correção da relação molar, embora possa contribuir para uma perda de comprimento no arco dentário. Por outro lado, o desenvolvimento vertical não foi influenciado ${ }^{127}$ talvez pela força em sentido inferior não ser aplicada exatamente sobre esses dentes, em decorrência da presença dos cantiléveres neste mecanismo de inserção. Contudo, a literatura mostra que este resultado independe do tipo de aparelho de Herbst utilizado ${ }^{92,106,129}$.

\section{Incisivos inferiores}

A indução de forças consideráveis, direcionadas em sentido anterior sobre o arco dentário inferior, desencadeou um movimento em mesma direção de todo o segmento dento-alveolar mandibular, resultando na inclinação expressiva e protrusão dos incisivos inferiores $59,65,126,127,138,139,140,144,168$. Concorda-se com a literatura, ser este um efeito inevitável e compensatório do resultado ortodôntico da aplicação do aparelho $^{180}$. Segundo PANCHERZ; HANSEN ${ }^{138}$ e PANCHERZ; MALMGREN; HÄGG; ÖMBLUS; HANSEN ${ }^{140}$, não há necessidade de se preocupar com a reação dos incisivos pois eles tendem a retornar para as suas posições originais após o tratamento.

Além da perda de ancoragem ser comprovada neste estudo, com a presença expressiva de vestibularização e protrusão dentária na região anterior do arco dentário ${ }^{132,139}$, pode-se também relacionar este efeito ao tipo de ancoragem utilizado, já que a presença do arco lingual também exerce uma força anterior nesses dentes $^{137}$. Entretanto, segundo PANCHERZ; HANSEN ${ }^{138}$, o tipo de aparelho e de ancoragem não influenciam na quantificação dessas alterações e sim o período de intervenção do tratamento. Com relação à intrusão dos incisivos inferiores, considera-se este efeito um achado relativo, pois este resultado pode ter sido influenciado pela acentuada vestibuloversão ${ }^{127,179}$.

\section{Relação Interdentária}

$\mathrm{Na}$ comparação estatística entre as alterações do tratamento com o aparelho de Herbst e as alterações do grupo controle 1, revela-se que as variáveis 
sobressaliência e relação molar se alteraram estatisticamente de modo significante. Verifica-se que o tratamento diminuiu satisfatoriamente a discrepância ânteroposterior inter-arcos o que revela a contribuição desta terapia na correção da relação molar de Classe II e do trespasse horizontal acentuado.

As alterações que favoreceram a melhora da relação interdentária, de acordo com as discussões previamente expostas, são decorrentes principalmente de alterações dentárias, que são, em essência, resultados da perda de ancoragem promovida pela terapia ${ }^{61,65,168}$. A lingualização dos incisivos superiores e a vestibularização dos inferiores contribuíram fortemente para a correção da sobressaliência, enquanto que a mesialização dos molares inferiores para a correção da relação molar distal. A inibição do padrão de irrupção dos molares superiores, permitindo que os molares inferiores apresentassem um trajeto de irrupção mais anterior e superior (mesmo este último não sendo significante) foi um dos mecanismos responsáveis pela correção das Classes II. O achado deste estudo, entretanto, discorda parcialmente com o da literatura que exprime uma combinação de efeitos esqueléticos e dentários na correção da relação interdentária de Classe II 65,66,92,124,134,138.

\section{Componente Tegumentar}

$\mathrm{Na}$ comparação estatística entre as alterações do tratamento com o aparelho de Herbst e as alterações do grupo controle 1, revela-se que as variáveis Ls-Prn Pog' e Li-Prn Pog' se alteraram estatisticamente de modo significante enquanto que a variável ângulo nasolabial não se alterou de modo significante. Verifica-se que o aparelho de Herbst influenciou o perfil tegumentar, em decorrência principalmente das movimentações ocorridas nos elementos dentários anteriores. A retrusão dos incisivos superiores e a protrusão dos incisivos inferiores apresentaram uma influência direta sobre os respectivos lábios, alterando-os na mesma direção. Estas respostas tegumentares, conseqüentemente, auxiliaram na correção da característica facial de Classe II dos pacientes. 
Embora se considere que o tratamento tenha influenciado o tegumento, ainda se questiona a extensão desses efeitos ${ }^{135}$. A variabilidade de resultados deve ser considerada, pois inúmeras são as variáveis que podem interferir no comportamento tecidual mole, exemplificadas pelo estado tensional dos lábios, espessura desses, quantidade de retração dos incisivos e tipo de aparelho utilizado $^{192}$.

\subsubsection{Tratamento com o aparelho Extrabucal de tração occipital}

\section{Componente Maxilar}

$\mathrm{Na}$ comparação estatística entre as alterações do tratamento com o aparelho Extrabucal de tração occipital e as alterações do grupo controle 2, revela-se que apenas a variável S.N.A do componente maxilar se alterou de modo significante. Verifica-se que o tratamento modificou a tendência de deslocamento anterior da maxila, comprovando um efeito inibitório sobre esse osso basal no sentido sagital e repercutiu, mesmo não sendo estatisticamente significante, numa restrição do aumento do comprimento efetivo da face média. A inclinação no sentido horário do plano palatino refletiu a alteração espacial ocorrida nesse osso basal.

De maneira geral, este resultado se assemelha ao da literatura dando crédito à aplicação de forças extrabucais para a efetivação de alterações ortopédicas $^{33,53,72,122,152,160,185,204}$, mediadas por remodelações suturais ${ }^{24,45,109}$, e pode ter sido influenciado pelo tempo extenso de tratamento ${ }^{49}$.

\section{Componente Mandibular}

$\mathrm{Na}$ comparação estatística entre as alterações do tratamento com o aparelho Extrabucal de tração occipital e as alterações do grupo controle 2, revela-se que as variáveis do componente mandibular não se alteraram estatisticamente de modo significante. Verifica-se que o tratamento não induziu repercussões intensas 
sobre o crescimento da mandíbula, embora o grupo experimental tenha demonstrado, na comparação intragrupos, entre as fases pré e pós-tratamento, um aumento significante na dimensão linear de $3,95 \mathrm{~mm}$. A constatação da estabilidade da posição sagital mandibular nos pacientes submetidos a esta terapia indica que a correção, com este tipo de aparelho, não propicia um deslocamento mais anterior da posição espacial da mandíbula, o que reforça o papel da inibição do crescimento anterior da maxila na tentativa de diminuição da convexidade facial. Estas evidências acordam com outros resultados da literatura, mesmo guardando as devidas diferenças metodológicas ${ }^{10,69,152,189,191}$.

\section{Relação Maxilomandibular}

$\mathrm{Na}$ comparação estatística entre as alterações do tratamento com 0 aparelho Extrabucal de tração occipital e as alterações do grupo controle 2, revela-se que as variáveis A.N.B e N.A.Pog se alteraram estatisticamente de modo significante. Verifica-se que o tratamento tanto diminuiu o grau de discrepância maxilomandibular como melhorou a convexidade facial, principalmente em decorrência do efeito inibitório da terapia sobre o osso basal superior no sentido sagital ${ }^{10,108}$. Este achado enobrece o tratamento, pois confirma a sua eficácia na melhora da relação distal entre os ossos basais ${ }^{57}$.

Entretanto, esta constatação positiva deve ser considerada com reservas, uma vez que a correção advinda do aparelho, reduzindo a protrusão maxilar e mantendo a posição mandibular, só é ideal nos casos onde há uma acentuada protrusão maxilar associada a uma posição mandibular normal, seguramente uma minoria nos casos de Classe II, divisão $1^{100}$.

\section{Componente Vertical}

$\mathrm{Na}$ comparação estatística entre as alterações do tratamento com 0 aparelho Extrabucal de tração occipital e as alterações do grupo controle 2, revela-se que as variáveis PoOr.PP, PoOr.PO, N-Me e S-Go se alteraram estatisticamente de 
modo significante, enquanto que as variáveis PoOr.GoMe e ENA-Me não se alteraram de modo significante. Verifica-se que o tratamento foi eficaz na manutenção do padrão original de crescimento craniofacial dos pacientes tratados, o que reforça a sua indicação em indivíduos meso e dolicofaciais. A rotação da mandíbula em sentido horário e o aumento da altura facial ântero-inferior foram evitados com esta terapia, não comprometendo, conseqüentemente, a estética facial dos pacientes. A extrusão controlada dos molares superiores foi, certamente, crucial para o resultado positivo do tratamento ${ }^{9,152}$.

A inclinação ântero-inferior dos planos palatino e oclusal se relacionou intimamente com o sistema de forças que este aparelho gerou sobre a maxila:

- A rotação do plano palatino no sentido horário reflete a criação de um momento (potencial ou tendência de rotação) em decorrência da linha de ação da força liberada, que se direciona para cima e para trás, passar abaixo do centro de resistência da maxila ${ }^{19}$; e

- A rotação do plano oclusal no sentido horário reflete a restrição do desenvolvimento no sentido vertical dos molares superiores em decorrência da direção da força ser para superior na região posterior da maxila.

O aumento significativo na altura facial anterior, em decorrência do comportamento vertical maxilar, foi equilibrado pela região posterior da face, deslocando harmoniosamente o plano mandibular.

\section{Componente Dento-alveolar Superior}

$\mathrm{Na}$ comparação estatística entre as alterações do tratamento com 0 aparelho Extrabucal de tração occipital e as alterações do grupo controle 2, revela-se que apenas as variáveis $\underline{6}-\mathrm{PP}$ e $\underline{6}$-SperpPO se alteraram estatisticamente de modo significante. Verifica-se que o objetivo primordial do tratamento, inibição do desenvolvimento normal dos dentes póstero-superiores para a inferior (extrusão) e para a anterior (mesialização), que seguem a tendência natural do comportamento maxilar $^{47,198}$, foi alcançado com êxito. 
Este resultado se relacionou estritamente com o sistema de forças gerado pelo aparelho na região posterior do arco dentário, em sentido superior (componente intrusivo) e posterior (componente distal), opondo-se ao movimento natural dos molares. Como se preconizou que a linha de ação de força passasse pelo centro de resistência desses dentes, as suas inclinações no sentido mésio-distal também foram mantidas, constatado pelo resultado não significante da variável $\underline{6} . P P$, favorecendo a estabilidade futura dos casos.

Estas respostas dentárias, também reportadas por diferentes autores $^{5,28,36,47,49,57,58,119,123,152,181}$, refletem o excelente controle sobre o aparelho no decorrer do tratamento.

\section{Componente Dento-alveolar Inferior}

$\mathrm{Na}$ comparação estatística entre as alterações do tratamento com o aparelho Extrabucal de tração occipital e as alterações do grupo controle 2, revela-se que apenas a variável $\overline{1}-\mathrm{NB}$ não se alterou estatisticamente de modo significante. Verifica-se que o tratamento, mesmo não transmitindo forças diretamente sobre arco dentário inferior, repercutiu em movimentações dentárias compensatórias às alterações dentárias superiores, bem como a restrição do movimento natural dos dentes superiores estimulou a mesialização dos dentes inferiores, acompanhando o crescimento natural da mandíbula.

Os molares inferiores responderam de maneira inversa ao efeito do tratamento sobre os molares superiores, extruindo-se $\mathrm{e}^{27}$ e a lingualização dos incisivos inferiores parece ser uma tendência de comportamento com a utilização de forças extrabucais $^{189}$. O sentido horário da rotação mandibular, mesmo não sendo estatisticamente significante, pode ter contribuído para uma maior extrusão dos incisivos inferiores, a fim de preservar o contato existente entre os dentes anteriores. 


\section{Relação Interdentária}

$\mathrm{Na}$ comparação estatística entre as alterações do tratamento com 0 aparelho Extrabucal de tração occipital e as alterações do grupo controle 2, revela-se que as variáveis sobressaliência e relação molar se alteraram estatisticamente de modo significante. Verifica-se que o tratamento diminuiu satisfatoriamente a discrepância ântero-posterior inter-arcos o que revela a contribuição desta terapia na correção da relação molar de Classe II e na melhora do trespasse horizontal acentuado.

A restrição do desenvolvimento normal dos molares superiores no sentido vertical e sagital, associada à mesialização e extrusão dos dentes inferiores, foi o contribuinte majoritário na correção da relação molar de Classe II e da sobressaliência acentuada ${ }^{5,123}$. Segundo HARVOLD ${ }^{27,69}$, o controle seletivo da extrusão dentária é uma ferramenta poderosíssima na correção das más oclusões.

\section{Componente Tegumentar}

$\mathrm{Na}$ comparação estatística entre as alterações do tratamento com 0 aparelho Extrabucal de tração occipital e as alterações do grupo controle 2, revela-se que apenas a variável Ls-Prn Pog' se alterou estatisticamente de modo significante. Embora se evidencie uma redução na projeção dos lábios superiores, ainda se questiona a extensão deste efeito, uma vez que os incisivos superiores mantiveramse em posição e o ângulo nasolabial estável. Mais uma vez a variabilidade de resultados deve ser considerada ${ }^{192}$. 


\subsection{Considerações finais}

Os resultados estatísticos evidenciaram que ambas as terapias promoveram alterações sobre o crescimento craniofacial, corrigindo a má oclusão inicial de Classe II, porém com mecanismos específicos de atuação. Os efeitos dento-esqueléticos se relacionaram estritamente com o sistema de forças gerado pelos aparelhos, confirmando as suas modalidades terapêuticas dentro da Ortopedia dos Maxilares.

O aparelho de Herbst com cantiléver promoveu maiores alterações dentoalveolares, em decorrência principalmente da perda substancial de ancoragem dentária inferior. A restrição do desenvolvimento dos molares superiores no sentido vertical associada à mesialização dos dentes inferiores foram as características principais na correção das Classes II, sendo consideradas na literatura tão ou mais importantes que as alterações esqueléticas ${ }^{55,112}$.

A expectativa de se encontrarem maiores repercussões sobre 0 crescimento mandibular, o que enquadra esta modalidade terapêutica dentro da Ortopedia Funcional dos Maxilares, foi obscurecida com este trabalho; no entanto, os resultados alcançados neste estudo são dependentes do tipo de aparelho e do protocolo de tratamento estabelecidos, não podendo ser totalmente julgados à risca com respeito às alterações esqueléticas e dentárias promovidas pelo aparelho de Herbst $^{204}$. Considera-se, também, o fato de que as tomografias computadorizadas ou mesmo as ressonâncias magnéticas não compreenderam a metodologia do trabalho, o que poderia ter mostrado com mais exatidão os efeitos ósseos remodeladores na articulação temporomandibular. A tendência, atualmente, em se utilizar estes novos recursos científicos está aumentando em virtude desses métodos de análise estabelecerem com mais precisão os efeitos a curto e a longo prazo na morfologia óssea e mole da articulação craniomandibular ${ }^{68,150,166,169}$, bem como averiguar a prevalência de sinais de desordens temporomandibulares relacionados com a terapia funcional fixa ${ }^{164}$.

Vale enfatizar que o crescimento mandibular é altamente complexo e passível de influência de infinitas variáveis, para se desconsiderar, na interpretação 
de dados científicos, a variação biológica entre os pacientes ${ }^{4,21,203}$. De acordo com $\operatorname{COBEN}^{36}$, o padrão de crescimento individual varia em seu ritmo, velocidade e potencial. GOLDSTEIN ${ }^{56}$ já dizia: o paciente é um indivíduo, e sendo assim, é infinito em sua variabilidade, fixo em seu padrão morfogenético e único em sua resposta biológica.

O aparelho Extrabucal de tração occipital também apresentou particularidades em seu modo de ação. Cefalometricamente, a indução ortopédica foi expressiva sobre o osso basal superior, alterando a sua direção de crescimento, não limitando os efeitos apenas à área dento-alveolar ${ }^{35,202}$. A restrição no sentido vertical e sagital dos molares superiores, juntamente com a mesialização dos dentes inferiores e o crescimento mandibular favorável nesse período de intervenção, contribuiu decisivamente para a correção da relação molar de Classe II. A comparação destes resultados com trabalhos prévios deve ser efetuada com cautela, uma vez que há diferenças básicas quanto ao protocolo de tratamento, considerando a idade de instituição e os aspectos mecânicos do aparelho (magnitude, duração e direção da força aplicada) ${ }^{27,210}$.

A conscientização e cooperação tanto dos pacientes como dos pais influenciaram imensamente os achados deste estudo, pois de acordo com vários autores, esses fatores são imprescindíveis na obtenção de bons resultados com a utilização de forças extrabucais ${ }^{4,57,119,120,199}$.

A utilização conjunta de ambos os aparelhos (associação do Herbst com o Extrabucal) pode ser uma opção superior de tratamento quando bem indicada, comparado com a instituição isolada ${ }^{60,61,175,204,205,206}$. WIESLANDER W $^{204,205,206}$ e HÄGG; DU; RABIE ${ }^{60}$ constataram que a correção da discrepância dento-esquelética foi altamente positiva com a união desses dois aparelhos e que os efeitos ortopédicos a longo prazo foram mais estáveis.

As duas modalidades terapêuticas trazem benefícios ao paciente, desde que corretamente indicadas e utilizadas. A individualização das planificações ortodônticas é indispensável já que regras genéricas podem comprometer os resultados almejados ou mesmo gerar o insucesso em atingir os objetivos 
inicialmente propostos $22,36,56,72,73,88,118,152,156$. A maioria dos pacientes submetidos à ortopedia desta pesquisa precisará de um segundo período terapêutico para a correção dos posicionamentos dentários e obtenção de oclusões anatômicas e funcionais ideais, refletindo um tratamento bifásico ${ }^{75,92,127,140,161}$.

Não se objetivou, com este estudo, analisar os efeitos pós-tratamento, considerando a estabilidade e a recidiva dos casos tratados com ambas as terapias. Para fins esclarecedores e complementares, encontram-se na literatura diversos trabalhos que discutem os vários aspectos pertinentes ao assunto, como a influência das disfunções musculares, a condição final oclusal alcançada com a terapêutica, a herança morfogenética, a época da instituição do tratamento e a utilização de contenções pós-tratamento $35,51,56,61,65,66,67,92,99,125,128,129,131,135,136,139,170,199,206$. É importante enfatizar que a eficácia de um tratamento se solidifica quanto à obtenção da estética facial e da estabilidade oclusal, além da função adequada, quando avaliados a longo prazo ${ }^{51,88}$. Logo, expectativas são lançadas para futuros estudos científicos, que abordem estas considerações nas atuais amostras experimentais. 
7- LIMITAÇÕES DO ESTUDO 


\section{$7 \quad$ LIMITAÇÕES DO ESTUDO}

Pela dificuldade em se parear cronologicamente os grupos experimentais pela média das idades iniciais e finais, não foi possível realizar um tratamento estatístico direto entre eles, e sim compará-los com seus respectivos grupos controles. Entretanto, ao se analisarem fielmente os grupos experimentais com os grupos controles, quanto ao número de componentes, idades no início e no final dos períodos de observação e padrões dento-esqueléticos, observou-se também uma certa restrição de compatibilidade.

Esta dificuldade de equiparação entre os grupos experimentais e os grupos controles também é assegurada na literatura, sendo uma consideração unânime entre os autores ${ }^{84,189}$, principalmente com relação às arquiteturas craniofaciais $^{15,17,39,136,202}$. A dificuldade em se obter grupos disponíveis de pacientes, por exemplo com más oclusões de Classe II não tratados ortodonticamente e que apresentem características compatíveis aos grupos experimentais, é um outro fator de grande relevância abordado em estudos prévios ${ }^{203}$. Exemplos de trabalhos científicos que não conseguiram parear integralmente os grupos componentes da amostra são os de PANCHERZ; RUF; KOHLHAS ${ }^{141}$, que utilizaram um grupo controle com oclusões ideais para se comparar com um grupo experimental com más oclusões de Classe II, tratados com o aparelho de Herbst e os de CROFT; BUSCHANG; ENGLISH; MEYER ${ }^{39}$ que, ao se comparar o grupo experimental com o controle, demonstraram diferenças cefalométricas estatisticamente significantes anteriores ao tratamento. JOHNSTON JÚNIOR ${ }^{85}$, avaliando os efeitos esqueléticos da instituição de aparelhos funcionais, relatou certa precariedade nestes tipos de estudos, devido à utilização de amostras não totalmente homogêneas e que nem sempre apresentam bons resultados na finalização terapêutica.

No atual estudo, mesmo que os grupos controles não tenham sido equiparados totalmente com os grupos experimentais, os dados cefalométricos obtidos evidenciaram alterações de crescimento ou mesmo alterações induzidas pelas mecânicas com tendências similares a trabalhos anteriores. 
8- CONCLUSÕES 


\section{CONCLUSÕES}

Com base na metodologia empregada e nos resultados obtidos, foi nos permitido referir as seguintes conclusões:

1) Com relação às alterações provocadas pelo tratamento com 0 aparelho de Herbst com cantiléver em relação ao seu grupo controle

a) Componente Maxilar

O crescimento maxilar não foi influenciado pelo tratamento.

b) Componente Mandibular

Mesmo que a medida cefalométrica S.N.B tenha sido alterada de modo significante, o tratamento não induziu repercussões intensas sobre o crescimento mandibular.

c) Relação maxilomandibular

O tratamento diminuiu o grau de discrepância maxilomandibular de modo significante em decorrência principalmente de alterações dentárias enquanto que a convexidade facial não foi influenciada pelo tratamento.

\section{d) Componente vertical}

O padrão de crescimento craniofacial não foi influenciado pelo tratamento, com aumento significante apenas do ângulo do plano oclusal em decorrência, principalmente, da restrição do desenvolvimento vertical dos molares superiores. 
e) Componente dento-alveolar superior

Os incisivos superiores foram lingualizados e retruídos e os molares superiores foram inclinados para a distal e restringidos no sentido vertical de modo significante pelo tratamento.

\section{f) Componente dento-alveolar inferior}

Os incisivos inferiores foram vestibularizados, protruídos e intruídos e os molares inferiores foram mesializados e inclinados para a mesial de modo significante pelo tratamento.

g) Relação interdentária

A relação molar de Classe II e o trespasse horizontal acentuado foram corrigidos de modo significante pelo tratamento.

h) Componente tegumentar

O perfil facial foi influenciado, positivamente, de modo significante, em decorrência de alterações dentárias pelo tratamento.

2) Com relação às alterações provocadas pelo tratamento com o aparelho Extrabucal de tração occipital em relação ao seu grupo controle

a) Componente Maxilar

O tratamento alterou a tendência de deslocamento anterior da maxila de modo significante.

b) Componente Mandibular

O crescimento mandibular não foi influenciado pelo tratamento. 
c) Relação maxilomandibular

O tratamento propiciou uma melhora significativa na relação maxilomandibular e na convexidade facial principalmente em decorrência do efeito inibitório da terapia sobre o osso basal superior no sentido sagital.

d) Componente vertical

O padrão de crescimento craniofacial não foi influenciado pelo tratamento; as alterações significativas no comportamento vertical maxilar foram equilibradas pelas regiões anterior e posterior da face.

e) Componente dento-alveolar superior

O tratamento restringiu o desenvolvimento dos molares superiores nos sentidos vertical e sagital de modo significante.

f) Componente dento-alveolar inferior

O tratamento repercutiu em movimentações dentárias compensatórias às alterações dentárias superiores de modo significante.

g) Relação interdentária

A relação molar de Classe II foi corrigida e o trespasse horizontal melhorado de modo significante pelo tratamento.

h) Componente tegumentar

A projeção do lábio superior foi reduzida de modo significante pelo tratamento. 


\section{REFERÊTCIAS BIBLIOGRÁFICAS}




\section{REFERÊNCIAS BIBLIOGRÁFICAS*}

1. ADAMS, C.D.; MEIKLE, M.C.; NORWICK, K.W.; TURPIN, D.L. Dentofacial remodelling produced by intermaxillary forces in Macaca mulatta. Archs Oral Biol., v.17, p.1519-35, 1972.

2. ANDERSON, D.L.; POPOVICH, F. Lower cranial height vs craniofacial dimensions in angle Class II malocclusion. Angle Orthodont., v.53, n.3, p.253-60, July 1983.

3. ANDERSON, D.L.; POPOVICH, F. Relation of cranial base flexure to cranial form and mandibular position. Amer. J. Phys. Anthropol., v.61, p.181-7, 1983.

4. ARMSTRONG, M.M. Controlling the magnitude, direction, and duration of extraoral force. Amer. J. Orthodont., v.59, n.3, p.217-43, Mar. 1971.

5. BAALACK, I.; POULSEN, A. Occipital anchorage for distal movement of the maxillary first molars. Acta Odont. Scand., v.24, n.1, p.307-25, 1966.

6. BAKKE, M.; PAULSEN, H.U. Herbst treatment in late adolescence: clinical, electromyographic, kinesiographic, and radiographic analysis of one case. Eur. J. Orthodont., v.11, n.4, p.397-407, Nov. 1989.

7. BALDRIDGE, J.P. A study of the relation of the maxillary first permanent molars to the face in Class I and Class II malocclusions. Angle Orthodont., v.11, n.2, p.100-9, Apr. 1941.

8. BALDRIDGE, J.P. Further studies of the relation of the maxillary first permanent molars to the face in Class I and Class II malocclusions. Angle Orthodont., v.20, n.1, p.3-10, Jan. 1950.

\footnotetext{
* Normas baseadas na Recomendação para uso no âmbito da Universidade de São Paulo, com base no documento "Referências Bibliográficas; exemplos", emanado do Conselho Supervisor do Sistema Integrado de Bibliotecas da USP, em reunião de 20 de setembro de 1990.
} 
9. BARROS, C.C. Ancoragem. In: FERREIRA, F.V. Ortodontia - diagnóstico e planejamento clínico. 2.ed. São Paulo: Artes Médicas, 1998. p. 399-425.

10. BARTON, J.J. High-pull headgear versus cervical traction: a cephalometric comparison. Amer. J. Orthodont., v.62, n.5, p.517-29, Nov. 1972.

11. BAUME, L.J.; DERICHSWEILER, H. Is the condylar growth center responsive to orthodontic therapy? Oral Surg., v.14, n.3, p.347-62, Mar. 1961.

12. BAUMRIND, S.; FRANTZ, R.C. The reliability of head film measurements. Conventional angular and linear measures. Amer. J. Orthodont., v.60, n.5, p.505-17, Nov. 1971.

13. BAUMRIND, S.; FRANTZ, R.C. The reliability of head film measurements. Landmark identification. Amer. J. Orthodont., v.60, n.2, p.111-27, Aug. 1971.

14. BAUMRIND, S.; KORN, E.L. Patterns of change in mandibular and facial shape associated with the use of forces to retract the maxilla. Amer. J. Orthodont., v.80, n.1, p.31-47, July 1981.

15. BAUMRIND, S.; KORN, E.L.; ISAACSON, R.J.; WEST, E.E.; MOLTHEN, R. Quantitative analysis of the orthodontic and orthopedic effects of maxillary traction. Amer. J. Orthodont., v.84, n.5, p.384-98, Nov. 1983.

16. BAUMRIND, S.; KORN, E.L.; MOLTHEN, R.; WEST, E.E. Changes in facial dimensions associated with the use of forces to retract the maxilla. Amer. $\mathbf{J}$. Orthodont., v.80, n.1, p.17-30, July 1981.

17. BAUMRIND, S.; MOLTHEN, R.; WEST, E.E.; MILLER, D.M. Mandibular plane changes during maxillary retraction - parte 1. Amer. J. Orthodont., v.74, n.1, p.32-40, July 1978. 
18. BAUMRIND, S.; MOLTHEN, R.; WEST, E.E.; MILLER, D.M. Mandibular plane changes during maxillary retraction - parte 2. Amer. J. Orthodont., v.74, n.6, p.603-20, Dec. 1978.

19. BILLIET, T.; PAUW, G.; DERMAUT, L. Location of the centre of resistance of the upper dentition and the nasomaxillary complex. An experimental study. Eur. J. Orthodont., v.23, n.3, p.263-73, June 2001.

20. BJÖRK, A. Variations in the growth pattern of the human mandible: longitudinal radiographic study by the implant method. J. Dent. Res., v.42, n.1, p.400-11, Jan./Feb. 1963.

21. BJÖRK, A. Prediction of mandibular growth rotation. Amer. J. Orthodont., v.55, n.6, p.585-99, June 1969.

22. BJÖRK, A.; SKIELLER, V. Facial development and tooth eruption - an implant study at the age of puberty. Amer. J. Orthodont., v.62, n.4, p.339-83, Oct. 1972.

23. BJÖRK, A.; SKIELLER, V. Normal and abnormal growth of the mandible. A synthesis of longitudinal cephalometric implant studies over a period of 25 years. Eur. J. Orthodont., v.5, n.1, p.1-46, Feb. 1983.

24. BRANDT, H.C.; SHAPIRO, P.A.; KOKICH, V.G. Experimental and postexperimental effects of posteriorly directed extraoral traction in adult Macaca fascicularis. Amer. J. Orthodont., v.75, n.3, p.301-17, Mar. 1979.

25. BREMEN, J.V.; PANCHERZ, H. Efficiency of Class II division 1 and Class II division 2 treatment in relation to different treatment approaches. Semin. Orthodont., v.9, n.1, p.87-92, Mar. 2003.

26. BROADBENT, B.H. A new x-ray technique. Angle Orthodont., v.1, n.2, p.45-66, Apr. 1931. 
27. BROWN, P. A cephalometric evaluation of high-pull molar headgear and facebow neck strap therapy. Amer. J. Orthodont., v.74, n.6, p.621-32, Dec. 1978.

28. BURKE, M.; JACOBSON, A. Vertical changes in high-angle Class II, division 1 patients treated with cervical or occipital pull headgear. Amer. J. Orthodont. Dentofac. Orthop., v.102, n.6, p.501-8, Dec. 1992.

29. BURKHARDT, D.R.; McNAMARA JÚNIOR, J.A.; BACCETTI, T. Maxillary molar distalization or mandibular enhancement: a cephalometric comparison of comprehensive orthodontic treatment including the pendulum and the Herbst appliances. Amer. J. Orthodont. Dentofac. Orthop., v.123, n.2, p.108-16, Feb. 2003.

30. BUSCHANG, P.H.; TANGUAY, R.; DEMIRJIAN, A.; La PALME, L.; TURKEWICZ, J. Mathematical models of longitudinal mandibular growth for children with normal and untreated Class II, division 1 malocclusion. Eur. J. Orthodont., v.10, n.3, p.227-34, Aug. 1988.

31. BUSCHANG, P.H.; TANGUAY, R.; TURKEWICZ, J.; DEMIRJIAN, A.; La PALME, L. A polynomial approach to craniofacial growth: description and comparison of adolescent males with normal occlusion and those with untreated Class II malocclusion. Amer. J. Orthodont. Dentofac. Orthop., v.90, n.5, p.437-42, Nov. 1986.

32. CARTER, N.E. Dentofacial changes in untreated Class II division 1 subjects. Brit. J. Orthodont., v.14, n.4, p.225-34, Nov. 1987.

33. CHACONAS, S.J.; CAPUTO, A.A.; DAVIS, J.C. The effects of orthopedic forces on the craniofacial complex utilizing cervical and headgear appliances. Amer. J. Orthodont., v.69, n.5, p.527-39, May 1976. 
34. CHARLIER, J.P.; PETROVIC, A.; HERRMANN-STUTZMANN, J. Effects of mandibular hyperpropulsion on the prechondroblastic zone of young rat condyle. Amer. J. Orthodont., v.55, n.1, p.71-4, Jan. 1969.

35. CLEALL, J.F. Dentofacial orthopedics. Amer. J. Orthodont., v.66, n.3, p.237-50, Sept. 1974.

36. COBEN, S.E. Growth and Class II treatment. Amer. J. Orthodont., v.52, n.1, p.526, Jan. 1966.

37. COOPER, M.H. A study of the naso-labial angle of the face in relation to mid-facial prognathism. Toronto, 1975. 56p. Thesis - University of Toronto.

38. COVO, S.; WEISBLATT, A. A longitudinal cephalometric study of anterior face height in males and females from 6 to 20 years of age. Toronto, 1972. 178p. Thesis - University of Toronto.

39. CROFT, R.S.; BUSCHANG, P.H.; ENGLISH, J.D.; MEYER, R. A cephalometric and tomographic evaluation of Herbst treatment in the mixed dentition. Amer. J. Orthodont. Dentofac. Orthop., v.116, n.4, p.435-43, Oct. 1999.

40. CRUZ, K.S.; HENRIQUES, J.F.C.; DAINESI, E.A.; JANSON, G. Efeitos dos aparelhos funcionais na correção da má oclusão de Classe II. Rev. Dent. Press Ortodon. Ortop. Facial, v.5, n.4, p.43-52, jul./ago. 2000.

41. CZIRAKI, S. The reproducibility and accuracy of cephalometric analysis using different digital imaging modalities and image compression. Toronto, 2001. 146p. Thesis - University of Toronto.

42. DISCHINGER, T.G. Edgewise bioprogressive Herbst appliance. J. Clin. Orthodont., v.23, n.9, p.608-17, Sept. 1989.

43. DOWNS, W.B. Variations in facial relationships: their significance in treatment and prognosis. Amer. J. Orthodont., v.34, n.1, p.812-40, Oct. 1948. 
44. DU, X.; HÄGG, U.; RABIE, A.B.M. Effects of headgear Herbst and mandibular step-by-step advancement versus conventional Herbst appliance and maximal jumping of the mandible. Eur. J. Orthodont., v.24, n.2, p.167-74, Apr. 2002.

45. ELDER, J.R.; TUENGE, R.H. Cephalometric and histologic changes produced by extraoral high-pull traction to the maxilla in Macaca mulatta. Amer. $\mathbf{J}$. Orthodont., v.66, n.6, p.599-617, Dec. 1974.

46. ELGOYHEN, J.C.; MOYERS, R.E.; McNAMARA JÚNIOR., J.A.; RIOLO, M.L. Craniofacial adaptation to protrusive function in young rhesus monkeys. Amer. J. Orthodont., v.62, n.5, p.469-80, Nov. 1972.

47. EPSTEIN, W.N. Analysis of changes in molar relationships by means of extra-oral anchorage (Head-cap) in treatment of malocclusion. Res. Illin., v.18, n.3, p.63-9, July 1948.

48. FEMALE template, horizontal - vertical growth pattern. Toronto, Burlington Growth Centre. Faculty of Dentistry - University of Toronto, s.d.

49. FIROUZ, M.; ZERNIK, J.; NANDA, R. Dental and orthopedic effects of high-pull headgear in treatment of Class II, division 1 malocclusion. Amer. $\mathbf{J}$. Orthodont. Dentofac. Orthop., v.102, n.3, p.197-205, Sept. 1992.

50. FRANCHI, L.; BACCETTI, T.; McNAMARA JÚNIOR, J.A. Treatment and posttreatment effects of acrylic splint Herbst appliance therapy. Amer. J. Orthodont. Dentofac. Orthop., v.115, n.4, p.429-38, Apr. 1999.

51. FRÄNKEL, R. The Herbst appliance and the incidence of recidivism. Amer. J. Orthodont. Dentofac. Orthop., v.116, n.6, p.16A-18A, Dec. 1999.

52. FRÄNKEL, R. Ask us. Amer. J. Orthodont. Dentofac. Orthop., v.120, n.1, p.17A, July 2001. 
53. GHAFARI, J.; SHOFER, F.S.; JACOBSSON-HUNT, U.; MARKOWITZ, D.L.; LASTER, L.L. Headgear versus function regulator in the early treatment of Class II, division 1 malocclusion: a randomized clinical trial. Amer. J. Orthodont. Dentofac. Orthop., v.113, n.1, p.51-61, Jan. 1998.

54. GIANCOTTI, A. Nonextraction treatment of a high-angle Class II malocclusion: a case report. Amer. J. Orthodont. Dentofac. Orthop., v.117, n.6, p.721-7, June 2000.

55. GIANELLY, A.A.; VALENTINI, V. The role of orthopedics and orthodontics in the treatment of Class II, division 1 malocclusions. Amer. J. Orthodont., v.69, n.6, p.668-78, June 1976.

56. GOLDSTEIN, A. The dominance of the morphological pattern: implications for treatment. Angle Orthodont., v.23, n.4, p.187-95, Oct. 1953.

57. GRABER, T.M. Extraoral force - facts and fallacies. Amer. J. Orthodont., v.41, n.7, p.490-505, July 1955.

58. GREENSPAN, R.A. Reference charts for controlled extraoral force application to maxillary molars. Amer. J. Orthodont., v.58, n.5, p.486-91, Nov. 1970.

59. HÄGG, U. Change in mandibular growth direction by means of a Herbst appliance? A case report. Amer. J. Orthodont. Dentofac. Orthop., v.102, n.5, p.456-63, Nov. 1992.

60. HÄGG, U.; DU, X.; RABIE, A.B.M. Initial and late treatment effects of headgearHerbst appliance with mandibular step-by-step advancement. Amer. J. Orthodont. Dentofac. Orthop., v.122, n.5, p.477-85, Nov. 2002.

61. HÄGG, U.; DU, X.; RABIE, A.B.M.; BENDEUS, M. What does Headgear add to Herbst treatment and to retention? Semin. Orthodont., v.9, n.1, p.57-66, Mar. 2003. 
62. HÄGG, U.; PANCHERZ, H. Dentofacial orthopaedics in relation to chronological age, growth period and skeletal development. An analysis of 72 male patients with Class II division 1 malocclusion treated with the Herbst appliance. Eur. J. Orthodont., v.10, n.3, p.169-76, Aug. 1988.

63. HÄGG, U.; TARANGER, J. Menarche and voice change as indicators of the pubertal growth spurt. Acta Odont. Scand., v.38, n.3, p.179-86, 1980.

64. HÄGG, U.; TARANGER, J. Skeletal stages ot the hand and wrist as indicators of the pubertal growth spurt. Acta Odont. Scand., v.38, n.3, p.187-200, 1980.

65. HANSEN, K. Treatment and posttreatment effects of the Herbst appliance on the dental arches and arch relationships. Semin. Orthodont., v.9, n.1, p.67-73, Mar. 2003.

66. HANSEN, K.; PANCHERZ, H. Long-term effects of Herbst treatment in relation to normal growth development: a cephalometric study. Eur. J. Orthodont., v.14, n.4, p.285-95, Aug. 1992.

67. HANSEN, K.; PANCHERZ, H.; HÄGG, U. Long-term effects of the Herbst appliance in relation to the treatment growth period: a cephalometric study. Eur. J. Orthodont., v.13, n.6, p.471-81, Dec. 1991.

68. HANSEN, K.; PANCHERZ, H.; PETERSSON, A. Long-term effects of the Herbst appliance on the craniomandibular system with special reference to the TMJ. Eur. J. Orthodont., v.12, n.3, p.244-53, Aug. 1990.

69. HARVOLD, E.P. The role of function in the etiology and treatment of malocclusion. Amer. J. Orthodont., v.54, n.12, p.883-98, Dec. 1968.

70. HATTON, M.E. A comparison of cranio-facial characteristics in treated and untreated cases at the Burlington Orthodontic Research Centre. J Canadian Dent. Assoc., v.28, n.1, p.1, Jan. 1962. 
71. HAYDAR, S.; ÜNER, O. Comparison of Jones jig molar distalization appliance with extraoral traction. Amer. J. Orthodont. Dentofac. Orthop., v.117, n.1, p.49-53, Jan. 2000.

72. HENRIQUES, J.F.C.; CARVALHO, P.E.G.; JANSON, G.R.P.; FREITAS, M.R.; ALMEIDA, R.R. Tratamento da má oclusão de Classe II, $1^{\circ}$ divisão em pacientes com padrão de crescimento vertical, utilizando a ancoragem extrabucal. Relato de dois casos clínicos. Rev. Dent. Press Ortodon. Ortop. Facial, v.5, n.4, p.53-61, jul./ago. 2000.

73. HENRIQUES, J.F.C.; CARVALHO, P.E.G.; PINZAN, A.; JANSON, G.R.P. A ancoragem extrabucal occipital (IHG) na correção da maloclusão de Classe II, divisão 1, associada ao aparelho fixo e à extração de quatro pré-molares. J. Bras. Ortodon. Ortop. Facial. n.29, p.7-16, set./out. 2000.

74. HENRIQUES, J.F.C.; FREITAS, M.R.; HAYASAKI, S.M. Principais indicações e efeitos da ancoragem extrabucal occipital (I.H.G.) no tratamento de jovens com má oclusão de Classe II, $1^{\text {a }}$ divisão de Angle: apresentação de um caso clínico. Rev. Dent. Press Ortodon. Ortop. Facial, v.4, n.2, p.33-38, mar./abr. 1999.

75. HENRIQUES, J.F.C.; FREITAS, M.R.; PINZAN, A.; SANTOS, E.C.A.; CUOGHI, O.A. Tratamento ortopédico ortodôntico: considerações gerais e relato de um caso clínico. Ortodontia, v.24, n.3, p.25-31, 1991.

76. HERBST, E. New ideas and apparatus in orthodontics. Int. J. Orthodont., v.18, n.9, p.962-9, July 1932.

77. HINTON, R.J.; McNAMARA JÚNIOR, J.A. Effect of age on the adaptive response of the adult temporomandibular joint - a study of induced protrusion in Macaca mulatta. Angle Orthodont., v.54, n.2, p.154-62, Apr. 1984. 
78. HITCHCOCK, H.P. A cephalometric description of Class II, division 1 malocclusion. Amer. J. Orthodont., v.63, n.4, p.414-23, Apr. 1973.

79. HOWE, R.P. The bonded Herbst appliance. J. Clin. Orthodont., v.16, n.10, p.663-7, Oct. 1982.

80. HOWE, R.P. Updating the bonded Herbst appliance. J. Clin. Orthodont., v.17, n.2, p.122-4, Feb. 1983.

81. HOWE, R.P. The acrylic-splint Herbst problem solving. J. Clin. Orthodont., v.18, n.7, p.497-501, July 1984.

82. HOWE, R.P.; McNAMARA JÚNIOR, J.A. Clinical management of the bonded Herbst appliance. J. Clin. Orthodont., v.17, n.7, p.456-63, July 1983.

83. HUTCHISON, L.G. Herbst appliance therapy in adolescent children: stability of skeletal and dental adaptation. Toronto, 1982. 200p. Thesis - University of Toronto.

84. JAKOBSSON, S.O. Cephalometric evaluation of treatment effect on Class II, division 1 malocclusions. Amer. J. Orthodont., v.53, n.6, p.446-57, June 1967.

85. JOHNSTON JÚNIOR, L.E. A comparative analysis of Class II treatments. In: VIG, P.S.; RIBBENS, K.A. Science and clinical judgment in orthodontics. Ann Arbor, University of Michigan - Center for human growth and development, 1986. p.103-48./ Craniofacial Growth Series, v.18/.

86. JOHNSTON JÚNIOR, L.E. Growth and the Class II patient: rendering unto Caesar. Semin. Orthodont., v.4, n.1, p.59-62, Mar. 1998.

87. KERR, W.J.S.; HIRST, D. Craniofacial characteristics of subjects with normal and postnormal occlusions - a longitudinal study. Amer. J. Orthodont. Dentofac. Orthop., v.92, n.3, p.207-12, Sept. 1987. 
88. KLOEHN, S.J. A new approach to the analysis and treatment in mixed dentition. Amer. J. Orthodont., v.39, n.3, p.161-86, Mar. 1953.

89. KONIK, M.; PANCHERZ, H.; HANSEN, K. The mechanism of Class II correction in late Herbst treatment. Amer. J. Orthodont. Dentofac. Orthop., v.112, n.1, p.87-91, July 1997.

90. KRAGT, G.; DUTERLOO, H.S.; ALGRA, A.M. Initial displacements and variations of eight human child skulls owing to high-pull headgear traction determined with laser holography. Amer. J. Orthodont., v.89, n.5, p.399-406, May 1986.

91. KUSA, L. A comparison of cephalometric superimposition techniques in orthodontics. Toronto, 2002. 49p. Thesis - University of Toronto.

92. LAI, M.; McNAMARA JÚNIOR, J.A. An evaluation of two-phase treatment with the Herbst appliance and preadjusted edgewise therapy. Semin. Orthodont., v.4, n.1, p.46-58, Mar. 1998.

93. LANGFORD, N.M. The Herbst appliance. J. Clin. Orthodont., v.15, n.8, p.55861, Aug. 1981.

94. LANGFORD, N.M. Updating fabrication of the Herbst appliance. J. Clin. Orthodont., v.16, n.3, p.173-4, Mar. 1982.

95. LIU, J.K.; CHEN, Y.T.; CHENG, K.S. Accuracy of computerized automatic identification of cephalometric landmarks. Amer. J. Orthodont. Dentofac. Orthop., v.118, n.5, p.535-40, Nov. 2000.

96. MANFREDI, C.; CIMINO, R.; TRANI, A.; PANCHERZ, H. Skeletal changes of Herbst appliance therapy investigated with more conventional cephalometrics and European norms. Angle Orthodont., v.71, n.3, p.170-6, June 2001. 
97. MARSCHNER, J.F.; HARRIS, J.E. Mandibular growth and Class II treatment. Angle Orthodont., v.36, n.1, p.89-93, Jan. 1966.

98. MARTINS, D.R.; JANSON, G.R.P.; ALMEIDA, R.R.; PINZAN, A.; HENRIQUES, J.F.; FREITAS, M.R. Atlas de crescimento craniofacial. São Paulo, Ed. Santos, 1998. 280p.

99. MARTINS, D.R.; URSI, W.J.S.; SCAVONE JÚNIOR, H. O aparelho de Herbst no tratamento ortopédico das más oclusões de Classe II. Odont. Master, v.1, n.4, p.1-14, 1994.

100. McNAMARA JÚNIOR, J.A. Components of Class II malocclusion in children 810 years of age. Angle Orthodont., v.51, n.3, p.177-202, July 1981.

101. McNAMARA JÚNIOR, J.A. A method of cephalometric evaluation. Amer. J. Orthodont., v.86, n.6, p.449-69, Dec. 1984.

102. McNAMARA JÚNIOR, J.A. Fabrication of the acrylic splint Herbst appliance. Amer. J. Orthodont. Dentofac. Orthop., v.94, n.1, p.10-8, July 1988.

103. McNAMARA JÚNIOR, J.A.; BRYAN, F.A. Long-term mandibular adaptations to protrusive function: an experimental study in Macaca mulatta. Amer. J. Orthodont. Dentofac. Orthop., v.92, n.2, p.98-108, Aug. 1987.

104. McNAMARA JÚNIOR, J.A.; CARLSON, D.S. Quantitative analysis of temporomandibular joint adaptations to protrusive function. Amer. $\mathbf{J}$. Orthodont., v.76, n.6, p.593-611, Dec. 1979.

105. McNAMARA JÚNIOR, J.A.; HOWE, R. Clinical management of the acrylic splint Herbst appliance. Amer. J. Orthodont. Dentofac. Orthop., v.94, n.2, p.142-9, Aug. 1988. 
106. McNAMARA JÚNIOR, J.A.; HOWE, R.P.; DISCHINGER, T.G. A comparison of the Herbst and Fränkel appliances in the treatment of Class II malocclusion. Amer. J. Orthodont. Dentofac. Orthop., v.98, n.2, p.134-44, Aug. 1990.

107. McNAMARA JÚNIOR, J.A.; PETERSON JÚNIOR, J.E.; PANCHERZ, H. Histologic changes associated with the Herbst appliance in adult Rhesus monkeys (Macaca mulatta). Semin. Orthodont., v.9, n.1, p.26-40, Mar. 2003.

108. MEACH, C.L. A cephalometric comparison of bony profile changes in Class II, division 1 patients treated with extraoral force and functional jaw orthopedics. Amer. J. Orthodont., v.52, n.5, p.353-70, May 1966.

109. MELDRUM, R.J. Alterations in the upper facial growth of Macaca mulatta resulting from high-pull headgear. Amer. J. Orthodont., v.67, n.4, p.393411, Apr. 1975.

110. MERCER, W.R. Dento-facial adaptation to protrusive functions in adolescent children with a modified Herbst appliance. Toronto, 1981. 109p. Thesis - University of Toronto.

111. METAXAS, A. Primate experiments in bone remodelling in the tempromandibular joint and facial complex using the Herbst appliance. Toronto, 1983. 194p. Thesis - University of Toronto.

112. MILLER, R.A. The Flip-lock Herbst appliance. J. Clin. Orthodont., v.30, n.10, p.552-8, Oct. 1996.

113. MOONEN, H.T.J. Prediction of mandibular growth direction in untreated Dental Class II subjects. London, 1991. 33p. Thesis - University of Western Ontario. 
114. MORO, A.; FUZIY, A.; FREITAS, M.R.; HENRIQUES, J.F.C.; JANSON, G.R.P. O aparelho de Herbst e suas variações. Rev. Dent. Press Ortodon. Ortop. Facial, v.5, n.2, p.35-41, mar./abr. 2000.

115. MORO, A; FUZIY, A.; FREITAS, M.R.; HENRIQUES, J.F.C.; JANSON, G.R.P. Descrição passo-a-passo do aparelho de Herbst com coroas de aço superiores e "Splint" removível inferior. Rev. Dent. Press Ortodon. Ortop. Facial, v.6, n.3, p.55-62, maio/jun. 2001.

116. MORO, A.; FUZIY, A.; FREITAS, M.R.; HENRIQUES, J.F.C.; JANSON, G.R.P. Descrição passo a passo do aparelho de Herbst com "Cantilever" (CBJ). J. Bras. Ortodon. Ortop. Facial, v.7, n.38, p.162-74, mar./abr. 2002.

117. MORO, A.; URIAS, D. Crescimento condilar: alterações frente à propulsão mandibular. Ortodontia, v.27, n.2, p.78-97, mai./ago. 1994.

118. MOYERS, R.E.; RIOLO, M.L.; GUIRE, K.E.; WAINRIGHT, R.L.; BOOKSTEIN, F.L. Differential diagnosis of Class II malocclusions. Part 1 - facial types associated with Class II malocclusions. Amer. J. Orthodont., v.78, n.5, p.477-94, Nov. 1980.

119. NELSON, B.G. What does extraoral anchorage accomplish? Amer. J. Orthodont., v.38, n.6, p.422-34, June 1952.

120. NORTHCUTT, M.E. The High-pull timing headgear. J. Clin. Orthodont., v.10, n.12, p.918-20, Dec. 1976.

121. ODEGAARD, J. Growth of the mandible studied with the aid of metal implant. Amer. J. Orthodont., v.57, n.2, p.145-57, Feb. 1970.

122. OLIVEIRA JÚNIOR, J.N. Avaliação comparativa das alterações dentoesqueléticas promovidas pelos aparelhos Jasper Jumper e Extrabucal com ancoragem cervical, ambos associados à aparelhagem fixa no tratamento da Classe II, divisão 1, de Angle. Bauru. 2002. 232p. 
Dissertação (mestrado) - Faculdade de Odontologia de Bauru, Universidade de São Paulo.

123. OPPENHEIM, A. Biologic orthodontic therapy and reality. Angle Orthodont., v.6, n.3, p.153-83, July 1936.

124. PANCHERZ, H. Treatment of Class II malocclusions by jumping the bite with the Herbst appliance - a cephalometric investigation. Amer. J. Orthodont., v.76, n.4, p.423-42, Oct. 1979.

125. PANCHERZ, $H$. The effect of continuous bite jumping on the dentofacial complex: a follow-up study after Herbst appliance treatment of Class II malocclusions. Eur. J. Orthodont., v.3, n.1, p.49-60, 1981.

126. PANCHERZ, H. The mechanism of Class II correction in Herbst appliance treatment - a cephalometric investigation. Amer. J. Orthodont., v.82, n.2, p.104-13, Aug. 1982.

127. PANCHERZ, H. The Herbst appliance - its biologic effects and clinical use. Amer. J. Orthodont., v.87, n.1, p.1-20, Jan. 1985.

128. PANCHERZ, H. The nature of Class II relapse after Herbst appliance treatment: a cephalometric long-term investigation. Amer. J. Orthodont. Dentofac. Orthop., v.100, n.3, p.220-33, Sept. 1991.

129. PANCHERZ, H. The effects, limitations, and long-term dentofacial adaptations to treatment with the Herbst appliance. Semin. Orthodont., v. 3, n. 4, p.232-43, Dec. 1997.

130. PANCHERZ, H. The modern Herbst appliance. In: GRABER, T.M.; RAKOSI, T.; PETROVIC, A.G. Dentofacial orthopedics with functional appliances. 2. ed. Chicago, Mosby, 1997. p.336-66. 
131. PANCHERZ, H. Entrevista. Rev. Dent. Press Ortodon. Ortop. Facial, v.5, n.4, p.1-3, jul./ago. 2000.

132. PANCHERZ, H. History, background, and development of the Herbst appliance. Semin. Orthodont., v.9, n.1, p.3-11, Mar. 2003.

133. PANCHERZ, H.; ANEHUS-PANCHERZ, M. Muscle activity in Class II, divison 1 malocclusions treated by bite jumping with the Herbst appliance. Amer. J. Orthodont., v.78, n.3, p.321-9, Sept. 1980.

134. PANCHERZ, H.; ANEHUS-PANCHERZ, M. The headgear effect of the Herbst appliance: a cephalometric long-term study. Amer. J. Orthodont. Dentofac. Orthop., v. 103, n. 6, p.510-20, June 1993.

135. PANCHERZ, H.; ANEHUS-PANCHERZ, M. Facial profile changes during and after Herbst appliance treatment. Eur. J. Orthodont., v.16, n.4, p.275-86, Aug. 1994.

136. PANCHERZ, H.; FACKEL, U. The skeletofacial growth pattern pré- and postdentofacial orthopaedics. A long-term study of Class II malocclusions treated with the Herbst appliance. Eur. J. Orthodont., v.12, n.2, p.209-18, May 1990.

137. PANCHERZ, H.; HÄGG, U. Dentofacial orthopedics in relation to somatic maturation - an analysis of 70 consecutive cases treated with the Herbst appliance. Amer. J. Orthodont., v.88, n.4, p.273-87, Oct. 1985.

138. PANCHERZ, H.; HANSEN, K. Occlusal changes during and after Herbst treatment: a cephalometric investigation. Eur. J. Orthodont., v.8, n.2, p.215-28, 1986.

139. PANCHERZ, H.; HANSEN, K. Mandibular anchorage in Herbst treatment. Eur. J. Orthodont., v.10, p.149-64, 1988. 
140. PANCHERZ, H.; MALMGREN, O.; HÄGG, U.; ÖMBLUS, J.; HANSEN, K. Class II correction in Herbst and Bass therapy. Eur. J. Orthodont., v.11, n.1, p.17-30, Feb. 1989.

141. PANCHERZ, H.; RUF, S.; KOHLHAS, P. Effective condylar growth and chin position changes in Herbst treatment: a cephalometric roentgenographic long-term study. Amer. J. Orthodont. Dentofac. Orthop., v.114, n.4, p.437-46, Oct. 1998.

142. PANGRAZIO-KULBERSH, V.; BERGER, J.L. Treatment of identical twins with Frankel and Herbst appliances: a comparison of results. Amer. J. Orthodont., v.103, n.2, p.131-7, Feb. 1993.

143. PATTERSON, A.R. A study to determine the correlation of "y-axis" to mandibular growth trends. Toronto, 1969. 31p. Thesis - University of Toronto.

144. PAULSEN, H.U.; KARLE, A.; BAKKE, M.; HERSKIND, A. CT-scanning and radiographic analysis of temporomandibular joints and cephalometric analysis in a case of Herbst treatment in late puberty. Eur. J. Orthodont., v.17, n.3, p.165-75, June 1995.

145. PETERSON JÚNIOR, J.E.; McNAMARA JÚNIOR, J.A. Temporomandibular joint adaptations associated with Herbst appliance treatment in juvenile Rhesus monkeys (Macaca mulatta). Semin. Orthodont., v.9, n.1, p.12-25, Mar. 2003.

146. PFEIFFER, J.P.; GROBÉRTY, D. Uma filosofia de tratamento combinado ortopédico-ortodôntico. Ortodontia, v.18, n.1, p.3-23, jan./jun. 1985.

147. POPOVICH, F. The Burlington orthodontic research centre. Amer. J. Orthodont., v.43, n.4, p.291-3, Apr. 1957. 
148. POPOVICH, F. Use of roentgenographic cephalometrics in growth studies. Proc. of First Canadian Conference on child growth and development. University of Montreal, 1969. p.156-79.

149. POPOVICH, F. A review of studies from the Burlington Growth Centre, 1956 1989. Essays in honor of Robert E. Moyers, W. S. Hunter and D.S. Carlson (Eds.) Craniofacial Growth. Ann Arbor, University of Michigan - Center for human growth and development, 1991. p.313-44./ Series 24.

150. POPOWICH, K.; NEBBE, B.; MAJOR, P.W. Effect of Herbst treatment on temporomandibular joint morphology: a systematic literature review. Amer. J. Orthodont. Dentofac. Orthop., v.123, n.4, p.388-94, Apr. 2003.

151. POULTON, D.R. A three-year survey of Class II malocclusions with and without headgear therapy. Amer. J. Orthodont., v.34, n.3, p.181-93, July 1964.

152. POULTON, D.R. The influence of extraoral traction. Amer. J. Orthodont., v.53, n.1, p.8-18, Jan. 1967.

153. RABIE, A.B.M.; CHAYANUPATKUL, A.; HÄGG, U. Stepwise advancement using fixed functional appliances: experimental perspective. Semin. Orthodont., v.9, n.1, p.41-46, Mar. 2003.

154. RAMFJORD, S.P.; ENLOW, R.D. Anterior displacement of the mandible in adult rhesus monkeys: long-term oservations. J. Prosthet. Dent., v.26, n.5, p.517-31, Nov. 1971.

155. RICKETTS, R.M. The influence of orthodontic treatment on facial growth and development. Angle Orthodont., v.30, n.3, p.103-33, July 1960.

156. RICKETTS, R.M. Cephalometric analysis and synthesis. Angle Orthodont., v.31, n.3, p.141-56, July 1961. 
157. RICKETTS, R.M. Perspectives in the clinical application of cephalometrics. Angle Orthodont., v.51, n.2, p.115-50, Apr. 1981.

158. RICKETTS, R.M.; BENCH, R.W.; HILGERS, J.J.; SCHULHOF, R. An overview of computorized cephalometrics. Amer. J. Orthodont., v.61, n.1, p.1-28, Jan. 1972.

159. RIEDEL, R.A. The relation of maxillary structures to cranium in malocclusion and in normal occlusion. Angle Orthodont., v.22, n.3, p.142-5, July 1952.

160. RIGHELLIS, E.G. Treatment effects of Fränkel, Activator and Extraoral traction appliances. Angle Orthodont., v.53, n.2, p.107-21, Apr. 1983.

161. ROGERS, M.B. Troubleshooting the Herbst appliance. J. Clin. Orthodont., v.36, n.5, p.268-74, May 2002.

162. ROGERS, M.B. Herbst appliance variations. J. Clin. Orthodont., v.37, n.3, p.156-9, Mar. 2003.

163. ROTHSTEIN, T.L. Facial morphology and growth from 10 to 14 years of age in children presenting Class II, division 1 malocclusion: a comparative roentgenographic cephalometric study. Amer. J. Orthodont., v.60, n.6, p.619-20, Dec. 1971.

164. RUF, S. Short- and long-term effects of the Herbst appliance on temporomandibular joint function. Semin. Orthodont., v.9, n.1, p.74-86, Mar. 2003.

165. RUF, S.; PANCHERZ, $H$. The effect of Herbst appliance treatment on the mandibular plane angle: a cephalometric roentgenographic study. Amer. J. Orthodont. Dentofac. Orthop., v.110, n.2, p.225-9, Aug. 1996. 
166. RUF, S.; PANCHERZ, H. Long-term TMJ effects of Herbst treatment: a clinical and MRI study. Amer. J. Orthodont. Dentofac. Orthop., v.114, n.5, p.47583, Nov. 1998.

167. RUF, S.; PANCHERZ, H. Temporomandibular joint growth adaptation in Herbst treatment: a prospective magnetic resonance imaging and cephalometric roentgenographic study. Eur. J. Orthodont., v.20, n.4, p.375-88, Aug. 1998.

168. RUF, S.; PANCHERZ, H. Dentoskeletal effects and facial profile changes in young adults treated with the Herbst appliance. Angle Orthodont., v. 69, n. 3, p. 239-46, June 1999.

169. RUF, S.; PANCHERZ, H. Temporomandibular joint remodeling in adolescents and young adults during Herbst treatment: a prospective longitudinal magnetic resonance imaging and cephalometric radiographic investigation. Amer. J. Orthodont. Dentofac. Orthop., v.115, n.6, p.607-18, June 1999.

170. RUF, S.; PANCHERZ, H. When is the ideal period for Herbst therapy - early or late? Semin. Orthodont., v.9, n.1, p.47-56, Mar. 2003.

171. RYGH, P.; MOYERS, R.E. Sistemas de forças e respostas dos tecidos às forças em ortodontia e ortopedia facial. In: MOYERS, R.E. Ortodontia. 4.ed. Rio de Janeiro: Guanabara Koogan, 1991. p. 258-80.

172. SADOWSKY, P.L.; PANCHERZ, H. Introduction. Semin. Orthodont., v.9, n.1, p.1-2, Mar. 2003.

173. SANDLER, P.J. Reproducibility of cephalometric measurements. Brit. J. Orthodont., v.15, n.2, p.105-10, May 1988.

174. SARNAS, K.V.; PANCHERZ, H.; RUNE, B.; SELVIK, G. Hemifacial microsomia treated with the Herbst appliance. Amer. J. Orthodont., v.82, n.1, p.68-74, July 1982. 
175. SCHIAVONI, R.; GRENGA, V. Nonextraction treatment of a high-angle Class II case with a modified Herbst appliance. J. Clin. Orthodont., v.28, n.8, p.453-7, Aug. 1994.

176. SCHIAVONI, R.; GRENGA, V.; MACRI, V. Treatment of Class II high angle malocclusions with the Herbst appliance: a cephalometric investigation. Amer. J. Orthodont. Dentofac. Orthop., v.102, n.5, p.393-409, Nov. 1992.

177. SESSLE, B.J.; WOODSIDE, D.G.; BOURQUE, P.; GURZA, S.; POWELL, G.; VOUDOURIS, J.; METAXAS, A.; ALTUNA, G. Effect of functional appliances on jaw muscle activity. Amer. J. Orthodont. Dentofac. Orthop., v.98, n.3, p.222-30, Sept. 1990.

178. SHAPERO, B.E. A study of the correlation of maxillary growth direction with mandibular growth direction. Toronto, 1974. 66p. Thesis University of Toronto.

179. SIDHU, M.S.; KHARBANDA, O.P.; SIDHU, S.S. Cephalometric analysis of changes produced by a modified Herbst appliance in the treatment of Class II division 1 malocclusion. Brit. J. Orthodont, v.22, n.1, p.1-12, Feb. 1995.

180. SILVA FILHO, O.G.; OZAWA, T.O.; FERRARI JÚNIOR, F.M.; AIELLO, C.A. Aparelho de Herbst - variação para uso na dentadura mista. Rev. Dent. Press Ortodon. Ortop. Facial, v.5, n.5, p.58-67, set./out. 2000.

181. SMITH, R.J.; BURSTONE, C.J. Mechanics of tooth movement. Amer. J. Orthodont., v.85, n.4, p.294-307, Apr. 1984.

182. STEINER, C.C. Cephalometrics for you and me. Amer. J. Orthodont., v.39, n.10, p.729-55, Oct. 1953. 
183. STÖCKLI, P.W.; WILLERT, H.G. Tissue reactions in the temporomandibular joint resulting from anterior displacement of the mandible in the monkey. Amer. J. Orthodont., v.60, n.2, p.142-55, Aug. 1971.

184. TAVANO, O. A radiografia carpal como estimador da idade óssea e do crescimento e desenvolvimento. Bauru, 1997. 54p. Faculdade de Odontologia - Universidade de São Paulo.

185. TEUSCHER, U. A growth-related concept for skeletal Class II treatment. Amer. J. Orthodont., v.74, n.3, p.258-75, Sept. 1978.

186. THOMPSON, G.W. Growth and development of facial structures. Toronto, 1971. 327p. Thesis - University of Toronto.

187. THOMPSON, G.W.; POPOVICH, F. A longitudinal evaluation of the Burlington Growth Centre Data. J. Dent. Res., v. 56, p.71-8, 1977.

188. TWEED, C.H. The Frankfort - mandibular incisor angle (FMIA) in orthodontic diagnosis, treatment planning and prognosis. Angle Orthodont., v.24, n.3, p.121-69, July 1954.

189. URSI, W.J.S. Alteração clínica da face em crescimento: uma comparação cefalométrica entre os aparelhos extrabucal cervical, Fränkel (FR - 2) e Herbst no tratamento das oclusões de Classe II, primeira divisão de Angle. Bauru. 1993. 168p. Tese (doutorado) - Faculdade de Odontologia de Bauru, Universidade de São Paulo.

190. URSI, W.J.S.; McNAMARA JÚNIOR, J. Crescimento craniofacial em pacientes apresentando maloclusões de Classe II e oclusão normal, entre os 10 anos e os 12 anos de idade. Rev. Dent. Press Ortodon. Ortop. Facial, v.2, n.5, p.49-59, set./out. 1997.

191. URSI, W.; McNAMARA JÚNIOR, J.; MARTINS, D.R. Alteração clínica da face em crescimento: uma comparação cefalométrica entre os aparelhos 
Extrabucal cervical, Fränkel e Herbst, no tratamento das Classes II. Rev. Dent. Press Ortodon. Ortop. Facial, v.4, n.5, p.77-108, set./out. 1999.

192. URSI, W.; McNAMARA JÚNIOR, J.; MARTINS, D.R.; URSI, W. Avaliação do perfil tegumentar de pacientes apresentando maloclusão de Classe II, tratados com os aparelhos Extra-bucal cervical, FR - 2 de Frankel e Herbst. Rev. Dent. Press Ortodon. Ortop. Facial, v.5, n.5, p.20-46, set./out. 2000.

193. VALANT, J.R. Increasing maxillary arch length with a modified Herbst appliance. J. Clin. Orthodont., v.23, n.12, p.810-4, Dec. 1989.

194. VALANT, J.R.; SINCLAIR, P.M. Treatment effects of the Herbst appliance. Amer. J. Orthodont. Dentofac. Orthop., v.95, n.2, p.138-47, Feb. 1989.

195. VION, P.E. Anatomia telerradiográfica em norma lateralis. In: Anatomia cefalométrica. São Paulo, Ed. Santos, 1994. p.5-91.

196. VOUDOURIS, J.C.; WOODSIDE, D.G.; ALTUNA, G.; ANGELOPOULOS, G.; BOURQUE, P.J.; LACOUTURE, C.Y. Condyle-fossa modifications and muscle interactions during Herbst treatment, Part 2. Results and conclusions. Amer. J. Orthodont. Dentofac. Orthop., v.124, n.1, p.13-29, July 2003.

197. VOUDOURIS, J.C.; WOODSIDE, D.G.; ALTUNA, G.; KUFTINEC, M.M.; ANGELOPOULOS, G.; BOURQUE, P.J. Condyle-fossa modifications and muscle interactions during Herbst treatment, Part 1. New technological methods. Amer. J. Orthodont. Dentofac. Orthop., v.123, n.6, p.604-13, June 2003.

198. WATSON, W.G. A computerized appraisal of the high-pull face-bow. Amer. J. Orthodont., v.62, n.6, p.561-79, Dec. 1972. 
199. WHEELER, T.T.; McGORRAY, S.P.; DOLCE, C.; TAYLOR, M.G.; KING, G.J. Effectiveness of early treatment of Class II malocclusion. Amer. $\mathbf{J}$. Orthodont. Dentofac. Orthop., v.121, n.1, p.9-17, Jan. 2002.

200. WHITE, L.W. Current Herbst appliance therapy. J. Clin. Orthodont., v.28, n.5, p.296-309, May 1994.

201. WHITE, R.C. The role of mandibular growth in occlusal development. St. Louis, 1983. Thesis - St. Louis University.

202. WIESLANDER, L. The effect of orthodontic treatment on the concurrent development of the craniofacial complex. Amer. J. Orthodont., v.49, n.1, p.15-27, Jan. 1963.

203. WIESLANDER, L. The effect of force on craniofacial development. Amer. J. Orthodont., v.65, n.5, p.531-8, May 1974.

204. WIESLANDER, L. Headgear-Herbst treatment in the mixed dentition. J. Clin. Orthodont., v.18, n.8, p.551-64, Aug. 1984.

205. WIESLANDER, L. Intensive treatment of severe Class II malocclusions with a headgear-Herbst appliance in the early mixed dentition. Amer. $\mathbf{J}$. Orthodont., v.86, n.1, p.1-13, July 1984.

206. WIESLANDER, L. Long-term effect of treatment with the headgear-Herbst appliance in the early mixed dentition. Stability or relapse? Amer. J. Orthodont. Dentofac. Orthop., v.104, n.4, p.319-29, Oct. 1993.

207. WOODSIDE, D.G. Entrevista. Rev. Dent. Press Ortodon. Ortop. Facial, v.7, n.2, p.7-10, mar./abr. 2002.

208. WOODSIDE, D.G.; ALTUNA, G.; HARVOLD, E.; HERBERT, M.; METAXAS, A. Primate experiments in malocclusion and bone induction. Amer. $\mathbf{J}$. Orthodont., v.83, n.6, p.460-8, June 1983. 
209. WOODSIDE, D.G.; METAXAS, A.; ALTUNA, G. The influence of functional appliance therapy on glenoid fossa remodeling. Amer. J. Orthodont. Dentofac. Orthop., v.92, n.3, p.181-98, Sept. 1987.

210. YOSHIDA, N.; JOST-BRINKMANN, P.G.; YAMADA, Y. Initial tooth movement under extraoral force and considerations for controlled molar movement. Angle Orthodont., v.65, n.3, p.199-208, 1995. 
ABSTRACT 


\section{CEPHALOMETRIC STUDY IN PATIENTS THAT DISPLAYED CLASS II, DIVISION 1 MALOCCLUSION TREATED WITH HERBST AND HIGH-PULL HEADGEAR APPLIANCES}

This study investigated the treatment effects on the craniofacial growth of Class II patients treated with Herbst and high-pull Headgear appliances. The sample was comprised of four groups, two experimental and two control groups. The experimental groups originated from Bauru Dental School, University of São Paulo. This consisted of 25 patients treated with the Herbst appliance, with an initial mean age of 12,01 years and 25 patients treated by the Headgear, with an initial mean age of 10,28 years. The control groups, matched by age with the experimental groups, were originated from the Burlington Growth Centre, located at the Faculty of Dentistry, University of Toronto.

All patients were assessed at the beginning $\left(T_{1}\right)$ and at the end of the treatment or observation period $\left(\mathrm{T}_{2}\right)$ and 33 cephalometric variables were established. The statistical comparison between each experimental group and the specific control group showed that both therapies, in short-term fashion, corrected the initial malocclusion. The dental changes (loss anchorage) were more pronounced with the Herbst appliance and a combination of factors (skeletal and dental changes) with the Headgear. However the effect in inhibiting the vertical development of the maxillary first molars, essential characteristic to correct the Class II molar relationship and to maintain the craniofacial growth pattern, were shown with both therapies. 
APÊNDICE 
TABELA 1 - Idade dos pacientes pertencentes ao grupo 1 (aparelho de Herbst) no início e no final do período de tratamento

\begin{tabular}{|c|c|c|c|c|}
\hline$N^{o}$ & Origem & Gênero & Idade ao início & Idade ao final \\
\hline 1 & FOB-USP & $F$ & 11,5 & 13,16 \\
\hline 2 & FOB-USP & M & 10,83 & 12,91 \\
\hline 3 & FOB-USP & M & 10,83 & 12,66 \\
\hline 4 & FOB-USP & $M$ & 11,66 & 13,58 \\
\hline 5 & FOB-USP & $\mathrm{F}$ & 10,83 & 13,66 \\
\hline 6 & FOB-USP & M & 11,5 & 13,16 \\
\hline 7 & FOB-USP & M & 11,16 & 13,41 \\
\hline 8 & FOB-USP & $\mathrm{F}$ & 12 & 14,5 \\
\hline 9 & FOB-USP & M & 13,5 & 14,91 \\
\hline 10 & FOB-USP & $\mathrm{F}$ & 11,33 & 12,75 \\
\hline 11 & FOB-USP & M & 12,16 & 13,5 \\
\hline 12 & FOB-USP & $\mathrm{F}$ & 12 & 14,58 \\
\hline 13 & FOB-USP & $\mathrm{F}$ & 11,25 & 13,5 \\
\hline 14 & FOB-USP & M & 13,16 & 14,75 \\
\hline 15 & FOB-USP & M & 13,66 & 15,08 \\
\hline 16 & FOB-USP & $\mathrm{F}$ & 12,08 & 13,66 \\
\hline 17 & FOB-USP & $M$ & 11,25 & 12,66 \\
\hline 18 & FOB-USP & M & 11,5 & 12,66 \\
\hline 19 & FOB-USP & M & 10,66 & 12,16 \\
\hline 20 & FOB-USP & $M$ & 12,75 & 15,33 \\
\hline 21 & FOB-USP & $\mathrm{F}$ & 13,91 & 15,5 \\
\hline 22 & FOB-USP & $M$ & 12,25 & 13,66 \\
\hline 23 & FOB-USP & M & 9,41 & 11 \\
\hline 24 & FOB-USP & $\mathrm{F}$ & 15 & 16,08 \\
\hline 25 & FOB-USP & $\mathrm{F}$ & 14,25 & 16,33 \\
\hline
\end{tabular}

FOB-USP = Faculdade de Odontologia de Bauru - Universidade de São Paulo $\mathrm{F}=$ Gênero femininoM = Gênero masculino 
TABELA 2 - Idade dos pacientes pertencentes ao grupo Controle 1 no início e no final do período de observação

\begin{tabular}{|c|c|c|c|c|}
\hline$N^{o}$ & Origem & Gênero & Idade ao início & Idade ao final \\
\hline 1 & BGC & $\mathrm{M}$ & 12,16 & 14,08 \\
\hline 2 & BGC & M & 12,08 & 14,16 \\
\hline 3 & BGC & $\mathrm{M}$ & 12,08 & 14,5 \\
\hline 4 & BGC & M & 12,08 & 14 \\
\hline 5 & BGC & M & 12,25 & 14 \\
\hline 6 & $B G C$ & $M$ & 12,08 & 14,08 \\
\hline 7 & BGC & $M$ & 12,16 & 14,25 \\
\hline 8 & $B G C$ & M & 12,16 & 14,33 \\
\hline 9 & BGC & $\mathrm{F}$ & 12,08 & 14,08 \\
\hline 10 & $B G C$ & $\mathrm{~F}$ & 12 & 14 \\
\hline 11 & BGC & $\mathrm{F}$ & 12 & 14 \\
\hline 12 & $B G C$ & $M$ & 12,25 & 14 \\
\hline 13 & $B G C$ & M & 12,08 & 14 \\
\hline 14 & $B G C$ & $F$ & 12,33 & 14,25 \\
\hline 15 & $B G C$ & M & 12 & 14 \\
\hline 16 & $B G C$ & $M$ & 12,08 & 14 \\
\hline 17 & $B G C$ & M & 12,16 & 14,25 \\
\hline 18 & $B G C$ & $F$ & 12,25 & 14 \\
\hline 19 & BGC & $M$ & 12 & 14 \\
\hline 20 & $B G C$ & M & 12 & 14,16 \\
\hline
\end{tabular}

BGC = Burlington Growth Centre, Faculdade de Odontologia da Universidade de Toronto $F=$ Gênero femininoM = Gênero masculino 
TABELA 3 - Idade dos pacientes pertencentes ao grupo 2 (aparelho Extrabucal) no início e no final do período de tratamento

\begin{tabular}{|c|c|c|c|c|}
\hline$N^{\circ}$ & Origem & Gênero & Idade ao início & Idade ao final \\
\hline 1 & FOB-USP & $\mathrm{F}$ & 11,08 & 12,16 \\
\hline 2 & FOB-USP & $\mathrm{F}$ & 10,25 & 11,08 \\
\hline 3 & FOB-USP & $M$ & 10,16 & 11,5 \\
\hline 4 & FOB-USP & $\mathrm{F}$ & 10,83 & 12,16 \\
\hline 5 & FOB-USP & $\mathrm{F}$ & 12 & 13,41 \\
\hline 6 & FOB-USP & $\mathrm{F}$ & 10,58 & 11,83 \\
\hline 7 & FOB-USP & $M$ & 11,83 & 13,5 \\
\hline 8 & FOB-USP & $M$ & 10,33 & 12,08 \\
\hline 9 & FOB-USP & $M$ & 11 & 11,83 \\
\hline 10 & FOB-USP & $\mathrm{F}$ & 10,58 & 11,91 \\
\hline 11 & FOB-USP & $\mathrm{F}$ & 8,41 & 9,91 \\
\hline 12 & FOB-USP & $\mathrm{M}$ & 8,5 & 10 \\
\hline 13 & FOB-USP & $\mathrm{F}$ & 10,58 & 12,33 \\
\hline 14 & FOB-USP & $\mathrm{F}$ & 9,58 & 11,16 \\
\hline 15 & FOB-USP & $\mathrm{F}$ & 9,33 & 10,75 \\
\hline 16 & FOB-USP & $F$ & 9,58 & 12,58 \\
\hline 17 & FOB-USP & $\mathrm{M}$ & 11 & 12,08 \\
\hline 18 & FOB-USP & $F$ & 9,33 & 11 \\
\hline 19 & FOB-USP & $\mathrm{F}$ & 9 & 10,25 \\
\hline 20 & FOB-USP & $\mathrm{F}$ & 10,66 & 12,25 \\
\hline 21 & FOB-USP & M & 10,83 & 12,33 \\
\hline 22 & FOB-USP & $M$ & 10 & 11,58 \\
\hline 23 & FOB-USP & $\mathrm{M}$ & 10,16 & 12,75 \\
\hline 24 & FOB-USP & $\mathrm{F}$ & 10 & 11,58 \\
\hline 25 & FOB-USP & $M$ & 11,5 & 13,66 \\
\hline
\end{tabular}

FOB-USP $=$ Faculdade de Odontologia de Bauru - Universidade de São Paulo $F=$ Gênero femininoM = Gênero masculino 
TABELA 4 - Idade dos pacientes pertencentes ao grupo Controle 2 no início e no final do período de observação

\begin{tabular}{|c|c|c|c|c|}
\hline$N^{\circ}$ & Origem & Gênero & Idade ao início & Idade ao final \\
\hline 1 & BGC & $\mathrm{M}$ & 9,08 & 12,16 \\
\hline 2 & $B G C$ & $F$ & 9,08 & 12,08 \\
\hline 3 & BGC & $\mathrm{F}$ & 9,08 & 12,25 \\
\hline 4 & $B G C$ & $\mathrm{~F}$ & 9,08 & 12 \\
\hline 5 & $B G C$ & $M$ & 9,16 & 12,16 \\
\hline 6 & $B G C$ & $\mathrm{~F}$ & 9 & 12,16 \\
\hline 7 & $B G C$ & M & 9,16 & 12,08 \\
\hline 8 & $B G C$ & M & 9 & 12,25 \\
\hline 9 & $B G C$ & M & 9,08 & 12,08 \\
\hline 10 & $B G C$ & $M$ & 9 & 12 \\
\hline 11 & $B G C$ & $M$ & 9,08 & 12,16 \\
\hline 12 & $B G C$ & M & 9 & 12,08 \\
\hline 13 & $B G C$ & M & 9,16 & 12,08 \\
\hline 14 & $B G C$ & M & 9 & 12,16 \\
\hline 15 & $B G C$ & $\mathrm{~F}$ & 9,33 & 12,25 \\
\hline 16 & $B G C$ & M & 9,16 & 12 \\
\hline 17 & $B G C$ & $\mathrm{~F}$ & 9,08 & 12,08 \\
\hline 18 & $B G C$ & M & 9 & 12,16 \\
\hline 19 & $B G C$ & M & 9 & 12,25 \\
\hline 20 & $B G C$ & M & 9,33 & 12,08 \\
\hline 21 & $B G C$ & $\mathrm{~F}$ & 9,16 & 12,33 \\
\hline 22 & $B G C$ & $M$ & 9,16 & 12 \\
\hline 23 & $B G C$ & $\mathrm{~F}$ & 9,16 & 12,08 \\
\hline 24 & $B G C$ & $M$ & 9 & 12 \\
\hline 25 & $B G C$ & $M$ & 9,08 & 12 \\
\hline 26 & $B G C$ & $\mathrm{~F}$ & 9,08 & 12,25 \\
\hline 27 & $B G C$ & $M$ & 9 & 12,08 \\
\hline 28 & $B G C$ & $M$ & 9,08 & 12,16 \\
\hline 29 & BGC & $M$ & 9,08 & 12,16 \\
\hline 30 & BGC & $M$ & 9 & 12 \\
\hline 31 & $B G C$ & $M$ & 9,08 & 12 \\
\hline
\end{tabular}

$B G C=$ Burlington Growth Centre, Faculdade de Odontologia da Universidade de Toronto $F=$ Gênero femininoM = Gênero masculino 


\section{Aparelho de Herbst}

\begin{tabular}{c|c|c|c|c|c|c|c}
\hline \multicolumn{5}{|c|}{ T1 } & \multicolumn{3}{c}{ T2 } \\
\hline S.N.A & S.N.B & A.N.B & N.A.Pog & S.N.A & S.N.B & A.N.B & N.A.Pog \\
\hline 78,4 & 77,3 & 1 & $-3,4$ & 79,9 & 78,3 & 1,6 & $-1,8$ \\
\hline 80,8 & 77,8 & 2,9 & 4,4 & 81,1 & 80,8 & 0,3 & 0,5 \\
\hline 85,3 & 78,1 & 7,2 & 14,1 & 91,2 & 81,6 & 9,6 & 17,9 \\
\hline 81,4 & 75,2 & 6,2 & 12,6 & 82,3 & 76,6 & 5,8 & 11,3 \\
\hline 76,9 & 70,2 & 6,8 & 10,3 & 76,5 & 71,6 & 4,9 & 5,9 \\
\hline 88 & 82,2 & 5,8 & 7,8 & 83,6 & 79,1 & 4,5 & 6,4 \\
\hline 77,2 & 72 & 5,2 & 7,4 & 75,7 & 73,6 & 2,1 & 1,4 \\
\hline 81,2 & 78,4 & 2,8 & 3,5 & 82,2 & 79 & 3,1 & 4,1 \\
\hline 83,8 & 77,2 & 6,6 & 14,4 & 86 & 78,5 & 7,5 & 16,9 \\
\hline 83,9 & 76,5 & 7,4 & 16,7 & 85,5 & 79,6 & 5,8 & 11,3 \\
\hline 85,3 & 76,4 & 8,9 & 16,5 & 82,9 & 79,2 & 3,7 & 6,2 \\
\hline 75,8 & 73,6 & 2,2 & 1 & 76,2 & 74,8 & 1,4 & $-1,7$ \\
\hline 81,2 & 75 & 6,2 & 10,8 & 78,8 & 74,9 & 3,9 & 4,7 \\
\hline 81,7 & 76 & 5,7 & 10,5 & 80,7 & 76,5 & 4,2 & 6,8 \\
\hline 88,6 & 82,6 & 6 & 11,5 & 89 & 83,6 & 5,4 & 10,2 \\
\hline 81,3 & 77,6 & 3,7 & 0,1 & 84,2 & 80 & 4,2 & 2 \\
\hline 78,1 & 72,5 & 5,6 & 7,1 & 78,4 & 75,4 & 3 & 2,1 \\
\hline 80,4 & 73,4 & 7 & 15,4 & 81,7 & 75,8 & 5,9 & 13,5 \\
\hline 78,9 & 75,2 & 3,6 & 6,6 & 79,2 & 77,1 & 2,1 & 3,9 \\
\hline 83,7 & 76,4 & 7,3 & 15,6 & 86,3 & 81 & 5,2 & 10,4 \\
\hline 89 & 81,8 & 7,3 & 12,9 & 83,9 & 78,6 & 5,3 & 10,9 \\
\hline 83,5 & 77,4 & 6,2 & 10,9 & 84,3 & 79,1 & 5,1 & 9,6 \\
\hline 81,6 & 75,6 & 6 & 8,9 & 81,6 & 76,9 & 4,6 & 6,7 \\
\hline 80,2 & 76,4 & 3,8 & 4 & 79,2 & 78,7 & 0,5 & $-1,9$ \\
\hline 85,2 & 77,8 & 7,4 & 12,6 & 82,9 & 78 & 4,9 & 8,3 \\
\hline & & & & & & & \\
\hline
\end{tabular}




\begin{tabular}{c|c|c|c|c|c|c|c}
\hline \multicolumn{7}{|c|}{ T1 } & \multicolumn{3}{|c}{ T2 } \\
\hline Co-Gn & Co-A & PoOr.PP & PoOr.GoMe & Co-Gn & Co-A & PoOr.PP & PoOr.GoMe \\
\hline 106,4 & 81,3 & 3,3 & 23 & 110,7 & 83,6 & 2,2 & 22,4 \\
\hline 115,5 & 91,3 & 10,4 & 22,4 & 121,3 & 93,7 & 8,3 & 22 \\
\hline 110,6 & 92,1 & 0,7 & 26,8 & 117,6 & 97,8 & $-2,1$ & 28,3 \\
\hline 111,3 & 95 & 2,9 & 19,1 & 113,6 & 94,7 & 2,2 & 19,3 \\
\hline 106,1 & 84 & 7,8 & 22,5 & 114,3 & 86,3 & 3,4 & 22,8 \\
\hline 102,9 & 83,8 & $-1,6$ & 22,6 & 108 & 85,3 & $-2,2$ & 24,7 \\
\hline 116,7 & 95,6 & $-0,7$ & 18,1 & 120,3 & 94 & $-0,3$ & 16,7 \\
\hline 117,5 & 87 & 2,7 & 31,1 & 123,2 & 90,4 & 2,3 & 27,8 \\
\hline 120,4 & 102,1 & $-0,5$ & 16,9 & 127 & 106,5 & $-1,6$ & 17,1 \\
\hline 105,6 & 84,4 & $-2,3$ & 31,4 & 115,3 & 89,8 & $-1,5$ & 29 \\
\hline 119,1 & 99 & 8 & 13 & 121,1 & 94,9 & 4,1 & 16,6 \\
\hline 106,3 & 82,2 & 1,4 & 24,4 & 116,9 & 89,3 & 1,5 & 23,1 \\
\hline 107,9 & 86,2 & 0 & 26,7 & 112,5 & 84,3 & -4 & 30,8 \\
\hline 113,7 & 91,3 & 5,6 & 20,1 & 120,3 & 95,4 & 5,2 & 19,2 \\
\hline 129,7 & 100,9 & 2,3 & 20,3 & 135,1 & 104,8 & 1,1 & 19,8 \\
\hline 114 & 92,7 & 1,7 & 18,4 & 120,6 & 97,5 & 3,2 & 17,7 \\
\hline 113,6 & 94,6 & 6,1 & 22,3 & 118,8 & 95,3 & 6,4 & 20,6 \\
\hline 114,8 & 97,9 & 1,1 & 29,7 & 121 & 101,1 & 2,7 & 26,7 \\
\hline 119,9 & 98,3 & 5,1 & 24,3 & 125,7 & 101,7 & 0,4 & 24,7 \\
\hline 117,2 & 98,2 & 1,5 & 18 & 121,4 & 96,9 & $-1,2$ & 17,6 \\
\hline 115,7 & 91,8 & 4,5 & 26,3 & 118,6 & 92,2 & 1,3 & 29,2 \\
\hline 107,7 & 89,1 & 3,1 & 18 & 114,9 & 92,6 & 2,9 & 18,1 \\
\hline 108,2 & 85,6 & 1,8 & 26,8 & 112,1 & 87,3 & 2,1 & 26,3 \\
\hline 108,6 & 87,8 & 5 & 13,5 & 110,9 & 86,8 & 5 & 11,6 \\
\hline 112,5 & 92,2 & 5,2 & 15,6 & 114,6 & 93,3 & 3,8 & 13,9 \\
\hline & & & & & & &
\end{tabular}




\begin{tabular}{c|c|c|c|c|c|c|c}
\hline \multicolumn{5}{|c|}{ T1 } & \multicolumn{3}{c}{ T2 } \\
\hline PoOr.PO & ENA-Me & N-Me & S-Go & PoOr.PO & ENA-Me & N-Me & S-Go \\
\hline 5,5 & 64,3 & 111,3 & 78,6 & 8,8 & 67,7 & 115,5 & 81,8 \\
\hline-2 & 70,7 & 115,6 & 70,4 & 1,6 & 70,8 & 119,8 & 76,9 \\
\hline 5,8 & 64,9 & 111,7 & 70,6 & 9,8 & 68,3 & 115,4 & 75,9 \\
\hline 2 & 65,8 & 114,1 & 76,2 & 5,6 & 66,8 & 118,2 & 81,8 \\
\hline 0,4 & 66,3 & 117,3 & 69,3 & 5,1 & 70,1 & 125,2 & 78,1 \\
\hline 8,4 & 56,7 & 99,7 & 69 & 11 & 60 & 107,8 & 70,4 \\
\hline 1,5 & 65 & 121,8 & 82,1 & 3,4 & 67 & 124 & 84,5 \\
\hline 6,2 & 70,6 & 122,9 & 77,4 & 4,1 & 69,6 & 124 & 78 \\
\hline 6,7 & 69,6 & 125,2 & 86,2 & 7,3 & 71,9 & 130,3 & 90,2 \\
\hline 9,4 & 66 & 115,4 & 68,2 & 8,6 & 69,6 & 118,8 & 71,8 \\
\hline$-0,4$ & 70,3 & 120,2 & 81,5 & 9,1 & 71 & 123,4 & 85,2 \\
\hline 5,6 & 63,5 & 113,5 & 69,3 & 8,3 & 65,2 & 117,9 & 73,2 \\
\hline 11 & 62,1 & 112,6 & 66,2 & 12,3 & 65,4 & 119,4 & 69 \\
\hline$-0,3$ & 67,1 & 116,4 & 71,5 & 1,2 & 73 & 123,5 & 79,5 \\
\hline$-1,1$ & 78,7 & 132,8 & 90,8 & 2,2 & 80 & 135,5 & 95,9 \\
\hline 0,6 & 58,7 & 108,1 & 69,7 & 2,8 & 61,9 & 111,4 & 74,4 \\
\hline 4,1 & 66,9 & 116,9 & 74 & 4,2 & 68,6 & 116,3 & 76,6 \\
\hline 10,9 & 72,2 & 128,6 & 77,9 & 14,8 & 74,5 & 133,7 & 85 \\
\hline$-0,7$ & 70,3 & 125 & 81,4 & 6,8 & 72,2 & 129,1 & 86,8 \\
\hline 2,8 & 65,3 & 119,4 & 77,9 & 6,1 & 66,1 & 121,6 & 85 \\
\hline 6,8 & 69,9 & 114,3 & 70,7 & 14 & 71,6 & 120,6 & 69,6 \\
\hline 2 & 64,2 & 115 & 80,8 & 6,3 & 67,3 & 120,2 & 85,4 \\
\hline 6,9 & 65 & 111,9 & 71 & 8,4 & 67,9 & 115,5 & 74 \\
\hline$-0,5$ & 60,4 & 107,8 & 75,1 & $-1,5$ & 58,6 & 105,8 & 76,2 \\
\hline 0,2 & 62,6 & 107,7 & 71,3 & 4 & 62,7 & 110 & 73,7 \\
\hline & & & & & & &
\end{tabular}




\begin{tabular}{c|c|c|c|c|c|c|c}
\hline \multicolumn{7}{c|}{ T1 } & \multicolumn{3}{c}{ T2 } \\
\hline $1 . P P$ & $1 . N A$ & 1 -NA & $1 . N B$ & $1 . P P$ & $1 . N A$ & 1 -NA & $1 . N B$ \\
\hline 118,3 & 38,2 & 8,1 & 10,8 & 112 & 29,1 & 5,4 & 24,7 \\
\hline 114,8 & 31,5 & 8,8 & 27,8 & 116,2 & 32,2 & 8,2 & 33,4 \\
\hline 119,2 & 27,5 & 5,5 & 36,3 & 115,2 & 19 & 0,3 & 40,3 \\
\hline 110 & 21,3 & 1,7 & 27 & 101,9 & 13,5 & 0,6 & 35,6 \\
\hline 118,2 & 32,1 & 6 & 26,3 & 108,2 & 20,7 & 3,7 & 31,4 \\
\hline 121,7 & 29,6 & 5,2 & 19,8 & 112,9 & 21,3 & 3 & 28,7 \\
\hline 120,6 & 32,4 & 5,7 & 23,7 & 113,2 & 27,4 & 6,6 & 34 \\
\hline 121,9 & 34,5 & 8,9 & 21,7 & 123,8 & 32,4 & 6,8 & 25,2 \\
\hline 107,9 & 14,4 & 2,3 & 31,7 & 108,6 & 11,4 & $-1,5$ & 34,9 \\
\hline 111,6 & 15,5 & 1,4 & 27,9 & 112,2 & 17 & 1,5 & 31,6 \\
\hline 124,9 & 32,9 & 8 & 27,2 & 114,2 & 25 & 8,2 & 41,2 \\
\hline 129 & 44,4 & 11,3 & 22,3 & 120,7 & 35,4 & 7,3 & 26,4 \\
\hline 98,1 & 4,2 & $-2,3$ & 23,1 & 112 & 19 & 2,5 & 27,6 \\
\hline 117 & 27,8 & 7,2 & 27 & 112 & 24,1 & 6,2 & 31,7 \\
\hline 124,2 & 30,3 & 6 & 28,7 & 122,3 & 27,4 & 4,6 & 41,2 \\
\hline 122,6 & 35,6 & 5,8 & 12,6 & 110,4 & 21,7 & 0,6 & 23,1 \\
\hline 107,8 & 25,5 & 4,7 & 22,5 & 103,9 & 23,1 & 4,9 & 27,8 \\
\hline 105,8 & 17,3 & 2,8 & 33,5 & 99,1 & 10,7 & 0,1 & 43,1 \\
\hline 111,9 & 27,1 & 6,5 & 31,7 & 113 & 28,1 & 6,9 & 37 \\
\hline 118,2 & 23,7 & 4,2 & 32,5 & 120,1 & 23,8 & 4,7 & 40,2 \\
\hline 119,2 & 29,4 & 7,1 & 37,4 & 110,9 & 20,4 & 4 & 42,9 \\
\hline 111,1 & 24,6 & 4,5 & 15,6 & 101,1 & 13,8 & 0,8 & 32,4 \\
\hline 117,8 & 29,7 & 6,4 & 28,5 & 116,5 & 28,2 & 6,6 & 35,9 \\
\hline 116 & 30,2 & 6,6 & 22 & 128,1 & 43,4 & 10,2 & 30,9 \\
\hline 126,3 & 34,6 & 7,6 & 35,9 & 119,7 & 29,4 & 6,4 & 41,1 \\
\hline
\end{tabular}




\begin{tabular}{c|c|c|c|c|c|c|c}
\hline \multicolumn{7}{c|}{$\mathrm{T} 1$} & \multicolumn{3}{c}{$\mathrm{T} 2$} \\
\hline $1-\mathrm{NB}$ & $1 . \mathrm{GoMe}$ & $\underline{6}-\mathrm{PP}$ & 6 -GoMe & 1 -NB & $1 . \mathrm{GoMe}$ & $\underline{6}-\mathrm{PP}$ & 6 -GoMe \\
\hline$-0,3$ & 85,6 & 21,2 & 27,7 & 3,5 & 98,8 & 20,7 & 30,1 \\
\hline 4,8 & 94,7 & 24,1 & 26,4 & 6,8 & 99,4 & 23,6 & 28,6 \\
\hline 6,3 & 104,2 & 21,6 & 27,9 & 8,4 & 107,5 & 22,8 & 31,2 \\
\hline 3,9 & 102,4 & 22,9 & 29,6 & 6,3 & 111,4 & 22,6 & 30,6 \\
\hline 5,3 & 96,6 & 21,2 & 27,2 & 6,5 & 102,7 & 24,1 & 28,7 \\
\hline 2,4 & 92,5 & 17,2 & 26,3 & 4,5 & 99 & 19 & 26,7 \\
\hline 5,5 & 103,3 & 22,6 & 31 & 6,9 & 113,9 & 23,6 & 31 \\
\hline 3,7 & 83,4 & 22,8 & 28,6 & 6,1 & 86,8 & 22,1 & 29,1 \\
\hline 6,3 & 108,5 & 23,9 & 32 & 6,6 & 109,7 & 24,5 & 33,1 \\
\hline 5,5 & 90,2 & 21,2 & 28,8 & 8,3 & 94,7 & 22,8 & 30,2 \\
\hline 7,2 & 103,1 & 21,5 & 31,8 & 9,4 & 115 & 21,2 & 32,8 \\
\hline 3,1 & 94,3 & 19,4 & 27,2 & 5,2 & 97,9 & 19,4 & 28,5 \\
\hline 3,1 & 88,7 & 20,5 & 27,2 & 5,4 & 91,6 & 21,9 & 27,7 \\
\hline 5 & 97,8 & 21,7 & 27,7 & 7,7 & 103,7 & 24,6 & 29,9 \\
\hline 6,9 & 98,3 & 27,4 & 35,5 & 10,7 & 110,7 & 27,2 & 37 \\
\hline$-0,1$ & 89,2 & 20,1 & 23,6 & 2,8 & 97,8 & 20,4 & 25,4 \\
\hline 3,6 & 97,3 & 21,1 & 27,8 & 6,2 & 103 & 23,2 & 27,3 \\
\hline 7,2 & 101,2 & 21,5 & 33,2 & 8,3 & 111,2 & 20,7 & 35,4 \\
\hline 6,1 & 101 & 22,7 & 33 & 7,7 & 109,1 & 22,1 & 34,9 \\
\hline 7,5 & 105,7 & 21,1 & 30,8 & 8,2 & 112,7 & 21,4 & 35,1 \\
\hline 8,3 & 104 & 23,5 & 27,6 & 8 & 107,2 & 23,9 & 27,9 \\
\hline 1,5 & 94,2 & 20,6 & 28,5 & 5 & 109,2 & 20,6 & 29,5 \\
\hline 6,2 & 97,7 & 20,5 & 29,2 & 10,1 & 103,8 & 20,5 & 30,5 \\
\hline 1,9 & 101,6 & 21,1 & 26,2 & 5,3 & 110 & 20,4 & 25,8 \\
\hline 7,4 & 110,8 & 21,3 & 29 & 9 & 118 & 21,5 & 28,1 \\
\hline
\end{tabular}




\begin{tabular}{c|c|c|c|c|c|c|c}
\hline \multicolumn{7}{c}{ T1 } & \multicolumn{3}{c}{ T2 } \\
\hline 1-PP & 1 -GoMe & 6-SperpPO & 6 -SperpPO & 1-PP & 1 -GoMe & 6-SperpPO & 6 -SperpPO \\
\hline 28,8 & 38,5 & 43,5 & 39,5 & 29 & 39,1 & 47 & 47,9 \\
\hline 30,1 & 40,2 & 48 & 46 & 31,1 & 39,6 & 50,1 & 57,2 \\
\hline 28 & 40,2 & 54,2 & 52,2 & 28,9 & 41,2 & 58,3 & 60,6 \\
\hline 28,5 & 41,6 & 46,9 & 44,3 & 29,4 & 39,9 & 49,6 & 50,7 \\
\hline 28 & 39,4 & 47,1 & 44,3 & 31,2 & 39,5 & 48,7 & 50,8 \\
\hline 22,1 & 34,9 & 50,9 & 46,9 & 25,1 & 35,2 & 54,8 & 52,2 \\
\hline 26,9 & 43,1 & 49,7 & 49,1 & 28,2 & 41,1 & 50,7 & 54,1 \\
\hline 29,5 & 39,6 & 49,9 & 48,8 & 28,7 & 40 & 48,1 & 53,9 \\
\hline 31,2 & 42,9 & 56,6 & 54,4 & 31,4 & 43 & 56,3 & 59 \\
\hline 25,6 & 39,4 & 55,7 & 52,3 & 27,5 & 40,9 & 55,9 & 59,4 \\
\hline 31,4 & 44,8 & 50,3 & 47,3 & 33,8 & 41,4 & 55,2 & 56,5 \\
\hline 25,8 & 38,6 & 47,7 & 46 & 27 & 37,6 & 50,2 & 53,7 \\
\hline 28,4 & 36,2 & 53,7 & 53,3 & 27,7 & 37,5 & 51 & 52,7 \\
\hline 28,5 & 42,9 & 48,9 & 46,1 & 32,4 & 43,5 & 50,3 & 55 \\
\hline 31,2 & 51,4 & 52,4 & 50,1 & 30,9 & 49,8 & 53,1 & 57,7 \\
\hline 24,6 & 36,5 & 47,8 & 46,3 & 26,7 & 36,4 & 50,3 & 53,9 \\
\hline 29 & 39,4 & 48,4 & 44,6 & 30,8 & 37,2 & 48,2 & 50,4 \\
\hline 28,1 & 42,4 & 62 & 59 & 30,4 & 41,6 & 66,4 & 66,3 \\
\hline 27,4 & 46,3 & 54,4 & 52,3 & 27,6 & 45,2 & 57,3 & 60,3 \\
\hline 26,8 & 43,1 & 54,4 & 53,1 & 25,7 & 43,1 & 57,8 & 60,1 \\
\hline 31,3 & 40,1 & 55,2 & 51,4 & 35,1 & 38 & 57,7 & 59,5 \\
\hline 28 & 41,9 & 45,5 & 42 & 29,5 & 40,1 & 50,8 & 53,2 \\
\hline 28,4 & 40,9 & 49,8 & 48,5 & 28,6 & 40,6 & 51,2 & 55,4 \\
\hline 27,1 & 37,3 & 45,5 & 44,5 & 26,5 & 36,7 & 42,6 & 48,6 \\
\hline 27,2 & 39,5 & 52,3 & 49,9 & 28,5 & 36,3 & 51,4 & 55,4 \\
\hline & & & & & & &
\end{tabular}




\begin{tabular}{c|c|c|c|c|c|c|c}
\hline \multicolumn{5}{|c|}{ T1 } & \multicolumn{5}{c}{ T2 } \\
\hline 1-SperpPO & 1-SperpPo & $\underline{6}$. PP & $6 . G$ Ge & 1-SperpPO & 1-SperpPo & $\underline{6}$. PP & $6 . \mathrm{GoMe}$ \\
\hline 72,7 & 63,5 & $-113,2$ & $-86,1$ & 77,4 & 73,5 & $-110,3$ & $-92,3$ \\
\hline 80,4 & 72,5 & $-102,6$ & $-77,5$ & 83,8 & 82,1 & $-108,7$ & $-83,7$ \\
\hline 86,3 & 77,8 & -97 & $-82,6$ & 89,6 & 84,8 & $-98,2$ & $-82,2$ \\
\hline 76,7 & 70,7 & $-103,3$ & $-86,9$ & 78,8 & 76,4 & $-106,9$ & $-89,6$ \\
\hline 77,6 & 67,5 & $-105,4$ & $-85,9$ & 78,4 & 73,8 & $-101,5$ & $-87,9$ \\
\hline 81,5 & 72,1 & $-94,9$ & $-90,1$ & 81 & 76,8 & $-104,2$ & $-91,8$ \\
\hline 81,9 & 74,7 & $-92,9$ & $-90,6$ & 82,5 & 79,8 & $-98,2$ & $-94,2$ \\
\hline 83,5 & 74,4 & $-103,7$ & $-85,1$ & 84,3 & 79 & $-110,3$ & $-92,3$ \\
\hline 91,3 & 85,2 & $-96,6$ & $-89,8$ & 94,5 & 90,5 & $-101,7$ & $-86,6$ \\
\hline 83,3 & 77,3 & $-100,8$ & $-84,2$ & 85,7 & 84,4 & $-105,8$ & $-85,7$ \\
\hline 92,3 & 78,2 & $-101,1$ & $-93,3$ & 95 & 90,6 & $-107,6$ & -98 \\
\hline 83,1 & 72,3 & $-103,3$ & $-86,1$ & 84,2 & 80,3 & $-105,6$ & $-89,6$ \\
\hline 78,3 & 75,2 & $-101,1$ & $-85,3$ & 79,7 & 77 & $-107,7$ & $-88,7$ \\
\hline 83,7 & 73,7 & $-100,9$ & $-83,8$ & 86,7 & 82,1 & $-104,3$ & -86 \\
\hline 88,7 & 80,2 & $-95,4$ & $-84,7$ & 92,7 & 90,3 & $-103,5$ & $-85,8$ \\
\hline 80 & 69,7 & $-97,6$ & $-81,5$ & 81,8 & 78,3 & $-103,9$ & $-85,7$ \\
\hline 80,3 & 71,7 & $-100,7$ & $-79,4$ & 80,9 & 78,1 & $-110,4$ & $-86,9$ \\
\hline 90,7 & 84,3 & $-106,8$ & $-86,2$ & 95,2 & 93,6 & $-113,7$ & $-91,4$ \\
\hline 85,6 & 80,1 & $-97,1$ & $-82,5$ & 90 & 87,7 & $-101,8$ & $-81,9$ \\
\hline 88 & 80,7 & $-93,5$ & $-82,3$ & 89,3 & 85,3 & $-92,1$ & $-86,4$ \\
\hline 91,3 & 82,6 & -108 & $-83,7$ & 91,3 & 87,3 & $-111,9$ & $-86,5$ \\
\hline 78,5 & 67,7 & $-99,9$ & -88 & 82,6 & 79,5 & $-107,3$ & $-90,4$ \\
\hline 81,2 & 73,5 & $-105,3$ & $-83,9$ & 84 & 81,2 & $-109,7$ & $-85,7$ \\
\hline 79,2 & 69,8 & $-97,5$ & $-89,1$ & 80,4 & 74,9 & $-101,8$ & $-94,1$ \\
\hline 85,1 & 75,2 & $-101,1$ & -90 & 85,3 & 81,3 & $-103,3$ & $-92,2$ \\
\hline
\end{tabular}


$\mathrm{T} 1$

$\mathrm{T} 2$

\begin{tabular}{c|c|c|c|c|c|}
\hline sobressaliência & relação molar & ângulo nasolabial & sobressaliência & relação molar & ângulo nasolabial
\end{tabular}

\begin{tabular}{c|c|c|c|c|c}
\hline 9,2 & 2,1 & 103,3 & 3,9 & $-2,6$ & 92,6 \\
\hline 7,9 & 1,2 & 103,4 & 1,7 & -8 & 116,8 \\
\hline 8,5 & 1,1 & 120 & 4,8 & $-4,2$ & 111 \\
\hline 6 & 1,2 & 127,8 & 2,4 & $-3,1$ & 125,2 \\
\hline 10,1 & 1,3 & 109,2 & 4,6 & $-3,1$ & 121,8 \\
\hline 9,4 & 2,1 & 86 & 4,2 & 0,6 & 92,6 \\
\hline 7,2 & $-0,2$ & 114,7 & 2,7 & $-4,5$ & 112,1 \\
\hline 9,1 & $-0,6$ & 118,3 & 5,3 & $-7,5$ & 112,6 \\
\hline 6,1 & 1,2 & 118,5 & 4 & -4 & 123 \\
\hline 6 & 1,4 & 109,3 & 1,3 & $-5,3$ & 112,3 \\
\hline 14,1 & 1,5 & 110,4 & 4,4 & -3 & 117,6 \\
\hline 10,8 & 0,4 & 112,6 & 3,9 & $-5,4$ & 108,2 \\
\hline 3,1 & $-1,4$ & 116,2 & 2,7 & $-4,2$ & 112 \\
\hline 10 & 2,2 & 111 & 4,6 & $-5,5$ & 103,7 \\
\hline 8,5 & 0,3 & 112,3 & 2,4 & $-6,2$ & 116,2 \\
\hline 10,3 & 0,8 & 99,3 & 3,5 & $-4,9$ & 93,8 \\
\hline 8,6 & 3,1 & 114,3 & 2,8 & $-3,6$ & 116,6 \\
\hline 6,4 & 1,1 & 112,8 & 1,6 & $-2,1$ & 117,4 \\
\hline 5,5 & 1,7 & 116,7 & 2,3 & $-4,2$ & 115,1 \\
\hline 7,3 & 0,9 & 115,3 & 4 & $-3,3$ & 108,4 \\
\hline 8,7 & 2 & 108,2 & 4 & $-3,9$ & 110,6 \\
\hline 10,8 & 2,2 & 123 & 3,1 & $-3,9$ & 128,3 \\
\hline 7,7 & $-0,7$ & 106,7 & 2,8 & $-6,2$ & 107,9 \\
\hline 9,4 & 0,3 & 114 & 5,5 & $-7,3$ & 109,8 \\
\hline 9,9 & 1,5 & 94,1 & 4 & $-5,1$ & 104,2 \\
\hline
\end{tabular}




\begin{tabular}{|c|c|c|c|}
\hline \multicolumn{2}{|c|}{ T1 } & \multicolumn{2}{|c|}{$\mathrm{T} 2$} \\
\hline Ls-PrnPog' & Li-PrnPog' & Ls-PrnPog' & Li-PrnPog' \\
\hline$-4,6$ & $-3,8$ & $-5,9$ & $-3,9$ \\
\hline 1,2 & 2,2 & $-0,7$ & 3,4 \\
\hline 1 & 2,1 & $-1,4$ & 1,2 \\
\hline 0,1 & 0 & $-1,9$ & $-0,3$ \\
\hline$-0,7$ & 1,6 & $-6,4$ & $-1,4$ \\
\hline 0,5 & $-0,4$ & 0,6 & $-0,4$ \\
\hline$-0,8$ & 2,4 & 0 & 3,5 \\
\hline$-4,2$ & 1,8 & $-4,1$ & 2,8 \\
\hline-2 & $-0,5$ & $-2,4$ & $-0,7$ \\
\hline$-1,4$ & 1,2 & $-4,1$ & 1,7 \\
\hline$-0,8$ & 2,2 & $-2,9$ & 3,4 \\
\hline$-2,2$ & $-1,3$ & $-4,8$ & $-1,7$ \\
\hline$-1,2$ & $-0,1$ & $-0,6$ & 0,6 \\
\hline$-1,1$ & 0 & $-2,7$ & 1,1 \\
\hline 0,8 & 0,7 & $-1,6$ & 1 \\
\hline$-3,5$ & $-5,9$ & $-6,3$ & $-4,4$ \\
\hline$-0,2$ & $-1,6$ & $-2,9$ & $-0,9$ \\
\hline 1 & 2,2 & $-1,7$ & 1,1 \\
\hline$-2,6$ & 0,2 & $-3,1$ & 1,9 \\
\hline 1,8 & 5,1 & $-0,9$ & 5,4 \\
\hline 3,8 & 1,9 & 0,8 & 2,3 \\
\hline 2 & 0,3 & -1 & 0,6 \\
\hline$-0,5$ & $-0,5$ & $-3,3$ & 1,6 \\
\hline$-4,5$ & $-2,2$ & $-6,5$ & -1 \\
\hline$-1,2$ & 0,9 & $-1,1$ & 3 \\
\hline
\end{tabular}




\section{Grupo Controle 1}

\begin{tabular}{c|c|c|c|c|c|c|c}
\hline \multicolumn{5}{|c|}{ T1 } & \multicolumn{4}{c}{ T2 } \\
\hline S.N.A & S.N.B & A.N.B & N.A.Pog & S.N.A & S.N.B & A.N.B & N.A.Pog \\
\hline 90,5 & 83,4 & 7,1 & 13,5 & 91,6 & 84,6 & 7 & 13 \\
\hline 88,6 & 84,8 & 3,8 & 5,8 & 83,6 & 80,1 & 3,5 & 4,8 \\
\hline 78,7 & 72,5 & 6,2 & 9,4 & 77,7 & 74,3 & 3,4 & 2,6 \\
\hline 83,1 & 79,1 & 4 & 5,6 & 84,3 & 79,5 & 4,8 & 6,1 \\
\hline 84,9 & 81,8 & 3,1 & 1,6 & 85,8 & 83,9 & 1,9 & $-2,6$ \\
\hline 83,8 & 83,2 & 0,6 & $-1,3$ & 85,3 & 83,6 & 1,7 & 0,7 \\
\hline 88,8 & 82,5 & 6,3 & 13,5 & 87,1 & 80,7 & 6,4 & 12,1 \\
\hline 83,9 & 79,9 & 3,9 & 8,3 & 81,5 & 78,1 & 3,4 & 6,4 \\
\hline 79,8 & 76,1 & 3,7 & 3,8 & 79,5 & 75,6 & 3,9 & 3,9 \\
\hline 87,4 & 81,2 & 6,1 & 9,4 & 86 & 81,5 & 4,5 & 6,4 \\
\hline 77,1 & 75 & 2,1 & 1,7 & 80,2 & 76,8 & 3,4 & 3,4 \\
\hline 79,5 & 76,7 & 2,7 & 1,4 & 79,5 & 76,4 & 3,1 & 2,3 \\
\hline 75,2 & 73,5 & 1,7 & $-0,3$ & 76,4 & 74,6 & 1,8 & $-1,2$ \\
\hline 79,5 & 75,2 & 4,2 & 6,1 & 79,1 & 76,1 & 3 & 2,5 \\
\hline 78,9 & 72,2 & 6,8 & 10,3 & 80,9 & 73,6 & 7,2 & 12 \\
\hline 77,8 & 73,4 & 4,4 & 7,7 & 77,5 & 73,1 & 4,4 & 7,1 \\
\hline 79,9 & 76,3 & 3,7 & 5,3 & 78,9 & 75,4 & 3,5 & 4,4 \\
\hline 76,6 & 72,7 & 3,9 & 6,5 & 79,6 & 75,1 & 4,5 & 8 \\
\hline 80,1 & 78,6 & 1,4 & 2,7 & 80 & 78 & 2 & 1,5 \\
\hline 73,9 & 69,7 & 4,1 & 4,8 & 73,3 & 70,4 & 2,9 & 1,2 \\
\hline
\end{tabular}




\begin{tabular}{c|c|c|c|c|c|c|c}
\hline \multicolumn{7}{|c|}{ T1 } & \multicolumn{3}{c}{ T2 } \\
\hline Co-Gn & Co-A & PoOr.PP & PoOr.GoMe & Co-Gn & Co-A & PoOr.PP & PoOr.GoMe \\
\hline 121,8 & 98 & $-0,6$ & 16,6 & 125,8 & 101,6 & 0 & 16,3 \\
\hline 109,9 & 89,1 & 4,2 & 20 & 117,5 & 93,8 & 6,1 & 17,5 \\
\hline 110,8 & 88,7 & 3 & 20,8 & 119,6 & 91,8 & 4,1 & 17,8 \\
\hline 109,2 & 80,1 & $-0,7$ & 34,6 & 112,8 & 84,4 & 0,2 & 31,4 \\
\hline 109,1 & 87,2 & 2,2 & 18,4 & 112,4 & 87,5 & -2 & 18,1 \\
\hline 120,6 & 94,9 & $-0,1$ & 23,1 & 127,1 & 98,7 & $-0,4$ & 21,6 \\
\hline 104,4 & 88,9 & $-1,3$ & 19,1 & 110,5 & 92,4 & -1 & 17,6 \\
\hline 104,7 & 87,5 & 1,9 & 18,7 & 113,1 & 90,1 & 0,2 & 20 \\
\hline 115,3 & 91,4 & $-0,9$ & 23,6 & 117,3 & 92,5 & $-1,4$ & 23,5 \\
\hline 114,9 & 91,9 & 6,2 & 16,6 & 117,6 & 93,1 & 4,6 & 15 \\
\hline 111,3 & 89,9 & 1,8 & 19,2 & 119,4 & 96,6 & 4,3 & 16,2 \\
\hline 116,4 & 91,2 & $-2,9$ & 25,4 & 117,2 & 91,8 & $-1,2$ & 23,5 \\
\hline 113,3 & 85,3 & 1,7 & 25,1 & 122,1 & 91,8 & 2,3 & 23,4 \\
\hline 116,7 & 93,6 & $-1,2$ & 27,6 & 120,6 & 99,2 & 3 & 20 \\
\hline 112,9 & 92,7 & $-1,1$ & 27,1 & 114,5 & 95,4 & $-2,5$ & 23,9 \\
\hline 112,6 & 94,3 & 3,2 & 22,9 & 116,5 & 97 & 1,5 & 25 \\
\hline 108 & 87,2 & 2,4 & 20,7 & 119 & 94,5 & $-0,4$ & 21,9 \\
\hline 112 & 89,8 & 1 & 25,2 & 118,2 & 93,4 & $-1,6$ & 25,4 \\
\hline 108,5 & 87,4 & 6 & 14,9 & 114,1 & 91,6 & 5,9 & 18,2 \\
\hline 104,8 & 82 & 2,6 & 22,3 & 105,2 & 81,6 & 0 & 24,4 \\
\hline
\end{tabular}




\begin{tabular}{c|c|c|c|c|c|c|c}
\hline \multicolumn{9}{|c|}{$\mathrm{T} 1$} & \multicolumn{3}{c}{$\mathrm{T} 2$} \\
\hline PoOr.PO & ENA-Me & N-Me & S-Go & PoOr.PO & ENA-Me & N-Me & S-Go \\
\hline 6,1 & 66,7 & 117,4 & 82,9 & 0,9 & 68,1 & 121,6 & 87,4 \\
\hline 8,3 & 55,8 & 98,3 & 66,2 & 4,1 & 60,2 & 111,5 & 72,1 \\
\hline 9,1 & 66,8 & 119,6 & 77,9 & 4,9 & 70,6 & 126,6 & 85,5 \\
\hline 14,2 & 69,9 & 116,7 & 69,8 & 10,3 & 70,9 & 119,6 & 72,2 \\
\hline 2,1 & 61,9 & 105,3 & 77,8 & 1,6 & 62,1 & 105,1 & 81,6 \\
\hline 6,4 & 61,9 & 114,1 & 76,5 & 5,4 & 68,2 & 124 & 84,6 \\
\hline 9,1 & 56,9 & 102,9 & 74,5 & 4,5 & 58,5 & 110,6 & 78,6 \\
\hline 7,7 & 57,8 & 104,9 & 72,2 & 5 & 61,8 & 114,2 & 74,5 \\
\hline 13 & 61,3 & 117,4 & 75,2 & 14,1 & 62,7 & 120,7 & 77,8 \\
\hline 0,2 & 63,7 & 109,3 & 76,6 & $-0,9$ & 64,4 & 112,9 & 80,2 \\
\hline 4,1 & 64,8 & 115,4 & 76,1 & 2,5 & 69,4 & 121,2 & 85,9 \\
\hline 11,2 & 62,8 & 114,7 & 75,1 & 7,5 & 63,3 & 117,5 & 74,2 \\
\hline 12,3 & 66,7 & 121,2 & 77 & 8,4 & 70,1 & 127,5 & 81,5 \\
\hline 11,3 & 69,2 & 121,6 & 79,7 & 7,3 & 66,7 & 122,1 & 83,8 \\
\hline 9,2 & 63,1 & 114,5 & 68,2 & 6,2 & 63,1 & 116,9 & 70,8 \\
\hline 8,8 & 65,3 & 116 & 72,7 & 8,4 & 66,9 & 119,6 & 75,9 \\
\hline 8 & 61,8 & 111,4 & 73,1 & 9,2 & 65,7 & 120,4 & 78,9 \\
\hline 9,3 & 65,1 & 117,7 & 69,8 & 9,5 & 68,8 & 124,4 & 77,9 \\
\hline 3 & 59 & 106,9 & 71 & 1,4 & 64 & 112,2 & 74,9 \\
\hline 8,6 & 63,5 & 114,3 & 72,4 & 8,3 & 66,1 & 117,3 & 73,9 \\
\hline
\end{tabular}




\begin{tabular}{c|c|c|c|c|c|c|c}
\hline \multicolumn{7}{|c|}{ T1 } & \multicolumn{3}{c}{ T2 } \\
\hline $1 . P P$ & $1 . N A$ & $1-N A$ & $1 . N B$ & $1 . P P$ & $1 . N A$ & 1 -NA & $1 . N B$ \\
\hline 112 & 13,8 & 1,7 & 30,2 & 120,7 & 22 & 3,7 & 30,7 \\
\hline 105,8 & 16,2 & 1,2 & 21,5 & 104,6 & 14,2 & 0,2 & 17,2 \\
\hline 106 & 17,6 & 2,2 & 27,7 & 101,4 & 16,3 & 4,1 & 20,3 \\
\hline 107,1 & 20,5 & 2,3 & 24,4 & 106,7 & 18,4 & 1,6 & 24,6 \\
\hline 111,2 & 26 & 5,9 & 20 & 108,8 & 22,7 & 5,8 & 20,9 \\
\hline 111,5 & 24,5 & 3,1 & 16,8 & 111 & 21,3 & 4,7 & 17,9 \\
\hline 107,7 & 13,2 & 1 & 33,6 & 104,3 & 8,8 & $-0,8$ & 29,7 \\
\hline 113,1 & 23,4 & 3,8 & 32,6 & 116,7 & 25 & 3,3 & 26,4 \\
\hline 101,1 & 13,6 & 0,6 & 21 & 93,3 & 6,4 & $-0,2$ & 17,3 \\
\hline 114,8 & 25 & 5,5 & 29,5 & 113,6 & 25 & 5,9 & 28,5 \\
\hline 105,7 & 19,6 & 2,5 & 25,2 & 102,4 & 17 & 1,1 & 25,1 \\
\hline 113,7 & 25,5 & 5,9 & 24,4 & 115,4 & 26,1 & 6,3 & 22,8 \\
\hline 100,8 & 15,2 & 2,5 & 19,9 & 107,2 & 20,8 & 4,5 & 18,4 \\
\hline 103,6 & 18,4 & 3,2 & 19,5 & 102,8 & 18,2 & 3,1 & 19,6 \\
\hline 115,2 & 23,1 & 4 & 31,3 & 120,8 & 26,6 & 4,7 & 31 \\
\hline 100,8 & 14,9 & 0,2 & 20,9 & 102,1 & 15,9 & 0,7 & 25,5 \\
\hline 95,3 & 8,6 & 1,3 & 15,8 & 96,6 & 9 & 0,6 & 11,8 \\
\hline 106 & 19 & 2,5 & 32,3 & 108 & 18,7 & 1,6 & 30 \\
\hline 115,1 & 29,9 & 5,9 & 28,5 & 107,4 & 24,4 & 4,9 & 26,2 \\
\hline 95,2 & 12,1 & $-0,8$ & 19 & 105,4 & 23,4 & 1,7 & 18,5 \\
\hline
\end{tabular}




\begin{tabular}{c|c|c|c|c|c|c|c}
\hline \multicolumn{5}{|c|}{$\mathrm{T1}$} & \multicolumn{3}{c}{$\mathrm{T} 2$} \\
\hline 1-NB & $1 . \mathrm{GoMe}$ & $\underline{6}-\mathrm{PP}$ & 6 -GoMe & 1-NB & 1.GoMe & $\underline{6}-\mathrm{PP}$ & 6 -GoMe \\
\hline 6,9 & 103 & 24,3 & 32,3 & 6,6 & 102,6 & 25,7 & 32,5 \\
\hline 2,3 & 91,5 & 18,5 & 24 & 1,4 & 86,8 & 19,8 & 27 \\
\hline 6,1 & 101,7 & 19,5 & 31,5 & 4,8 & 96,7 & 23,3 & 33,1 \\
\hline 4,2 & 87,9 & 19,5 & 29,5 & 4,5 & 89,4 & 21,3 & 31,2 \\
\hline 2,3 & 97,3 & 23,1 & 24,3 & 1,5 & 100,5 & 25,7 & 24,3 \\
\hline 0 & 87,5 & 21,9 & 24,3 & 1,3 & 88,7 & 22,7 & 27,5 \\
\hline 4,8 & 107,6 & 18,9 & 28,3 & 4,6 & 103,9 & 20,6 & 28,8 \\
\hline 4,8 & 106,3 & 17,8 & 28 & 4,1 & 97,9 & 21,2 & 29 \\
\hline 2,7 & 94,5 & 19,8 & 26,4 & 2 & 92,2 & 21,1 & 27,4 \\
\hline 6,3 & 103,1 & 21,8 & 28,7 & 5,1 & 104,8 & 23,2 & 28 \\
\hline 2,5 & 100,2 & 24,3 & 28 & 2,9 & 102,5 & 25,7 & 31,5 \\
\hline 2,3 & 96,5 & 21,4 & 27,2 & 2,9 & 94,2 & 22,9 & 25,8 \\
\hline 2 & 89,2 & 22,4 & 29,1 & 2,4 & 88,1 & 24,5 & 30 \\
\hline 4,1 & 92,1 & 22,5 & 29,1 & 1,7 & 94,9 & 22,4 & 31,1 \\
\hline 6,9 & 99,8 & 20,2 & 30,1 & 7,6 & 102,7 & 21,2 & 30,7 \\
\hline 2,4 & 93,3 & 20,4 & 30,3 & 3,7 & 97,3 & 21,8 & 31,1 \\
\hline 0,5 & 89,6 & 20 & 27 & $-0,2$ & 86,2 & 22,9 & 28,3 \\
\hline 5,6 & 103 & 21,6 & 27,7 & 5,4 & 101,6 & 24,1 & 30,4 \\
\hline 3,8 & 103,9 & 18,3 & 26,7 & 3,5 & 101,1 & 22 & 28 \\
\hline 2,2 & 95,1 & 20,3 & 28,8 & 2,2 & 95,1 & 22,7 & 29,3 \\
\hline
\end{tabular}




\begin{tabular}{c|c|c|c|c|c|c|c}
\hline \multicolumn{7}{c}{ 11 } & \multicolumn{3}{c}{ T2 } \\
\hline 1-PP & 1-GoMe & 6-SperpPO & 6 -SperpPO & 1-PP & 1-GoMe & 6 -SperpPO & 6 -SperpPO \\
\hline 29,9 & 41,5 & 62,4 & 59,6 & 29,4 & 43,4 & 64 & 62,7 \\
\hline 26,3 & 31,7 & 55,4 & 53 & 27 & 35,4 & 57,8 & 55,5 \\
\hline 30 & 40,8 & 51,4 & 50,5 & 31,5 & 43,8 & 54,3 & 52,6 \\
\hline 27,9 & 41,1 & 49,9 & 48,9 & 27,4 & 42,6 & 52,8 & 51,8 \\
\hline 28,6 & 37,1 & 41,9 & 39,4 & 29,3 & 38,4 & 40,2 & 38,5 \\
\hline 26,7 & 36,6 & 53,9 & 48,5 & 28,7 & 41,6 & 54,9 & 53,7 \\
\hline 25,9 & 36,5 & 49,6 & 47,7 & 24,8 & 37,3 & 52,1 & 51,8 \\
\hline 25,2 & 36,2 & 51,3 & 50,4 & 25,7 & 38,7 & 51,9 & 52,1 \\
\hline 29,4 & 35,4 & 55,1 & 53,1 & 30,8 & 36,5 & 56,3 & 54,2 \\
\hline 27,9 & 40,2 & 49,6 & 47,8 & 28,1 & 40,3 & 50,1 & 48,2 \\
\hline 30 & 38,1 & 50,6 & 50,5 & 31,4 & 40,3 & 53,2 & 53,5 \\
\hline 29 & 37,5 & 51,8 & 50,4 & 29,1 & 38,8 & 53,7 & 48,8 \\
\hline 30,7 & 37 & 54,6 & 52,2 & 31,6 & 39,4 & 55,7 & 52,4 \\
\hline 31 & 39,8 & 52 & 50,6 & 30,9 & 39,4 & 54,7 & 55,5 \\
\hline 26,9 & 40 & 56,1 & 53,7 & 25,1 & 41,7 & 57,9 & 55,2 \\
\hline 28,8 & 38,8 & 50,7 & 50,6 & 29,4 & 40,6 & 51,2 & 50,2 \\
\hline 28,8 & 36,8 & 50,2 & 48 & 31,5 & 38,4 & 55,2 & 53,5 \\
\hline 28,5 & 38,8 & 52,7 & 48,3 & 30 & 41,6 & 55,4 & 50,6 \\
\hline 24,7 & 35,4 & 50,2 & 49,6 & 28,1 & 38,7 & 49,1 & 49,1 \\
\hline 28 & 38 & 48,3 & 45,7 & 28,5 & 39,3 & 47,1 & 43,5 \\
\hline
\end{tabular}




\begin{tabular}{c|c|c|c|c|c|c|c}
\hline \multicolumn{7}{|c|}{$\mathrm{T} 1$} & \multicolumn{3}{c}{ T2 } \\
\hline 1-SperpPO & 1 -SperpPo & 6.PP & $6 . G o M e$ & 1-SperpPO & 1-SperpPo & $6 . P P$ & $6 . G o M e$ \\
\hline 94,6 & 89,5 & $-98,8$ & $-89,6$ & 96 & 88,3 & $-93,1$ & $-89,9$ \\
\hline 81,3 & 77,8 & $-99,3$ & $-88,8$ & 82,6 & 78,8 & $-101,9$ & $-95,4$ \\
\hline 84,4 & 79,6 & $-106,3$ & $-88,4$ & 83,4 & 79,3 & $-106,3$ & $-90,7$ \\
\hline 77,2 & 74 & $-104,5$ & $-82,1$ & 79,1 & 75,7 & $-100,7$ & $-80,6$ \\
\hline 74,2 & 67,1 & $-99,6$ & $-82,1$ & 71,8 & 65,9 & $-100,7$ & -88 \\
\hline 84,7 & 81 & $-105,3$ & $-95,3$ & 93,8 & 88 & $-101,9$ & -90 \\
\hline 77,1 & 73,1 & $-98,9$ & $-89,1$ & 77,8 & 74,5 & $-96,7$ & $-91,5$ \\
\hline 80,6 & 76,6 & $-97,9$ & $-86,7$ & 80,1 & 76,2 & $-94,2$ & $-85,1$ \\
\hline 84,1 & 81,2 & $-107,5$ & $-89,8$ & 83,1 & 80 & $-105,1$ & $-82,9$ \\
\hline 83,2 & 76 & $-101,2$ & $-88,3$ & 82,8 & 75,9 & $-99,9$ & -92 \\
\hline 78,5 & 75,8 & $-98,7$ & $-87,6$ & 81,3 & 78,3 & $-97,1$ & $-86,6$ \\
\hline 83,5 & 76,7 & $-102,9$ & $-92,3$ & 85 & 77,6 & $-95,6$ & $-86,1$ \\
\hline 77,1 & 74,2 & $-102,2$ & $-88,4$ & 80,2 & 75,4 & $-101,3$ & $-90,2$ \\
\hline 82,9 & 78,1 & $-97,4$ & $-86,2$ & 84,9 & 79,5 & $-95,5$ & $-83,3$ \\
\hline 84,9 & 78,9 & $-98,9$ & $-87,3$ & 87,7 & 80,8 & -97 & $-84,4$ \\
\hline 76,7 & 73 & -104 & $-83,6$ & 77,5 & 74,5 & $-101,6$ & $-91,1$ \\
\hline 79,3 & 73,9 & $-108,5$ & $-91,8$ & 82,3 & 76,9 & $-100,2$ & $-89,7$ \\
\hline 79,6 & 77,3 & $-101,8$ & -91 & 81,7 & 79,1 & $-100,9$ & $-88,3$ \\
\hline 82 & 78,1 & $-105,7$ & $-89,9$ & 78,9 & 75 & $-103,6$ & $-90,1$ \\
\hline 69,5 & 67,4 & $-104,9$ & $-93,3$ & 68,5 & 65,7 & $-104,2$ & $-92,2$ \\
\hline
\end{tabular}




\begin{tabular}{c|c|c|c|c|c}
\hline & \multicolumn{2}{|c|}{$\mathrm{T} 1$} & \multicolumn{3}{c}{ T2 } \\
\hline sobressaliência & relação molar & ângulo nasolabial & sobressaliência & relação molar & ângulo nasolabial \\
\hline 5,1 & 1,3 & 110,3 & 7,7 & $-0,2$ & 91,4 \\
\hline 3,5 & 1 & 123,7 & 3,8 & 0,8 & 127,4 \\
\hline 4,8 & $-1,1$ & 145 & 4,1 & 0,2 & 142,5 \\
\hline 3,2 & $-0,9$ & 131,2 & 3,4 & $-1,2$ & 125,1 \\
\hline 7,1 & 1,7 & 90,9 & 5,9 & 0 & 102,9 \\
\hline 3,7 & 3,6 & 102,8 & 5,8 & $-0,6$ & 103,5 \\
\hline 4 & 0,6 & 128 & 3,3 & -1 & 118,9 \\
\hline 4 & $-0,8$ & 133,8 & 3,9 & $-1,1$ & 112,1 \\
\hline 2,9 & 0,3 & 122,7 & 3,1 & 0,9 & 119 \\
\hline 7,2 & 1 & 102 & 6,9 & 0,9 & 112,2 \\
\hline 2,7 & $-1,2$ & 125,3 & 3 & $-1,2$ & 126,4 \\
\hline 6,8 & -1 & 101,5 & 7,4 & 3,3 & 113,3 \\
\hline 2,9 & 0,6 & 119,4 & 4,8 & 1,1 & 125,9 \\
\hline 4,8 & $-0,2$ & 107,9 & 5,4 & $-1,8$ & 122,1 \\
\hline 6 & 0,9 & 112,5 & 6,9 & 1,3 & 139 \\
\hline 3,7 & $-1,4$ & 121,5 & 3 & -1 & 100,6 \\
\hline 5,4 & 0,2 & 106,1 & 5,4 & $-0,4$ & 94,7 \\
\hline 2,3 & 2,4 & 125,2 & 2,6 & 2,6 & 139,3 \\
\hline 3,9 & $-0,5$ & 112 & 3,9 & $-1,4$ & 107,5 \\
\hline 2,1 & 0,7 & 111,3 & 2,8 & 1,3 & 97,1 \\
\hline
\end{tabular}




\begin{tabular}{c|c|c|c}
\hline \multicolumn{2}{|c|}{ T1 } & \multicolumn{2}{c}{ T2 } \\
\hline Ls-PrnPog' & Li-PrnPog' & Ls-PrnPog' & Li-PrnPog' \\
\hline 0,3 & 2,6 & 0,2 & 3 \\
\hline$-2,8$ & $-2,7$ & $-3,7$ & $-2,1$ \\
\hline 1,1 & 1,6 & $-4,6$ & $-4,5$ \\
\hline$-3,2$ & $-2,5$ & $-4,3$ & $-4,2$ \\
\hline$-2,6$ & $-4,1$ & $-2,2$ & $-3,6$ \\
\hline$-2,3$ & $-0,9$ & -3 & $-3,7$ \\
\hline$-2,5$ & $-1,5$ & -3 & $-2,2$ \\
\hline$-5,2$ & $-2,8$ & $-4,4$ & $-2,8$ \\
\hline$-7,1$ & $-4,6$ & $-7,5$ & $-4,4$ \\
\hline$-1,5$ & $-0,3$ & 0 & 1,1 \\
\hline$-5,8$ & $-6,4$ & $-5,8$ & $-5,2$ \\
\hline$-4,2$ & -3 & $-1,6$ & 0,8 \\
\hline$-3,7$ & $-2,7$ & $-3,9$ & $-2,1$ \\
\hline$-2,4$ & $-1,8$ & $-0,9$ & $-1,6$ \\
\hline 0,6 & 1,2 & $-1,4$ & -1 \\
\hline$-0,9$ & $-1,4$ & $-1,8$ & $-2,6$ \\
\hline 0,4 & 0,9 & $-4,9$ & $-2,6$ \\
\hline$-1,3$ & $-1,6$ & $-2,2$ & $-2,7$ \\
\hline$-2,2$ & 2,1 & $-0,5$ & 0,8 \\
\hline$-5,7$ & $-3,5$ & $-8,9$ & -5 \\
\hline
\end{tabular}




\section{Aparelho Extrabucal}

\begin{tabular}{c|c|c|c|c|c|c|c}
\hline \multicolumn{9}{|c|}{ T1 } & \multicolumn{4}{c}{ T2 } \\
\hline S.N.A & S.N.B & A.N.B & N.A.Pog & S.N.A & S.N.B & A.N.B & N.A.Pog \\
\hline 81,1 & 73,8 & 7,3 & 13 & 81 & 75,9 & 5,1 & 9,2 \\
\hline 81,9 & 76,6 & 5,3 & 10,4 & 83,3 & 77,4 & 5,9 & 12,3 \\
\hline 80 & 72,8 & 7,2 & 15,8 & 80,3 & 74,8 & 5,5 & 10,3 \\
\hline 82,2 & 79 & 3,2 & 2,1 & 81,1 & 79 & 2 & $-1,6$ \\
\hline 81,7 & 75 & 6,7 & 10,4 & 83 & 76,2 & 6,7 & 10,9 \\
\hline 81,7 & 76,2 & 5,4 & 11 & 79,4 & 76,3 & 3,1 & 6,2 \\
\hline 75,3 & 70,5 & 4,8 & 10,4 & 76,1 & 72,6 & 3,5 & 8,2 \\
\hline 77,9 & 71,9 & 6 & 11,5 & 76,4 & 71,7 & 4,7 & 7,8 \\
\hline 78,5 & 74,7 & 3,8 & 10,3 & 76,6 & 73,2 & 3,4 & 7,8 \\
\hline 84,2 & 78,2 & 6 & 11,1 & 83,5 & 78,1 & 5,4 & 8,5 \\
\hline 88,8 & 78,2 & 10,6 & 21,1 & 85,8 & 78 & 7,8 & 15,4 \\
\hline 80 & 74,2 & 5,9 & 11,9 & 79,3 & 73,8 & 5,5 & 10,8 \\
\hline 81,7 & 75,7 & 6 & 10,9 & 79,5 & 74,6 & 5 & 7,9 \\
\hline 75 & 72,2 & 2,8 & 3,5 & 75,8 & 72,8 & 3 & 2,6 \\
\hline 75,8 & 69,9 & 5,8 & 10,4 & 74,3 & 70,2 & 4,1 & 6,8 \\
\hline 82,7 & 77,7 & 4,9 & 7,9 & 82,3 & 78,9 & 3,4 & 5,5 \\
\hline 92,7 & 81,4 & 11,3 & 23,9 & 87,5 & 77,5 & 10 & 20,6 \\
\hline 78,7 & 73,9 & 4,8 & 6,9 & 80,1 & 76,7 & 3,4 & 3,7 \\
\hline 80,7 & 70,6 & 10,1 & 20,9 & 80,7 & 71 & 9,8 & 22,3 \\
\hline 79,5 & 73 & 6,4 & 12,1 & 75 & 72,8 & 2,2 & 3,8 \\
\hline 80,8 & 72,5 & 8,3 & 19,6 & 77,9 & 72,5 & 5,4 & 12 \\
\hline 82,6 & 77,6 & 5 & 11 & 81,9 & 78,6 & 3,3 & 6,9 \\
\hline 80,2 & 75,3 & 4,9 & 9,1 & 79,5 & 75,7 & 3,8 & 7,1 \\
\hline 82,6 & 74,7 & 7,8 & 14 & 80,6 & 74,1 & 6,5 & 10,7 \\
\hline 85 & 75,4 & 9,6 & 20,5 & 84,8 & 75,8 & 9 & 19,5 \\
\hline
\end{tabular}




\begin{tabular}{|c|c|c|c|c|c|c|c|}
\hline \multicolumn{4}{|c|}{$\mathrm{T} 1$} & \multicolumn{4}{|c|}{$\mathrm{T} 2$} \\
\hline Co-Gn & Co-A & PoOr.PP & PoOr.GoMe & Co-Gn & Co-A & PoOr.PP & PoOr.GoMe \\
\hline 110,3 & 89,1 & 3,2 & 25,6 & 117,1 & 91,5 & 2,5 & 25,8 \\
\hline 118,2 & 90,5 & 10 & 33,5 & 118,5 & 93,9 & 10,8 & 29,6 \\
\hline 103,5 & 85,8 & 6,5 & 26,3 & 108,8 & 85,5 & 2,6 & 30,5 \\
\hline 115,8 & 88,4 & 2,5 & 23,5 & 124,1 & 91,5 & 1,1 & 23 \\
\hline 108 & 83,1 & 5,6 & 30,5 & 111,1 & 85,5 & 7 & 28,7 \\
\hline 108,8 & 88 & 6,8 & 27,1 & 110,9 & 87 & 5,8 & 27 \\
\hline 116,5 & 91,9 & 2 & 30,3 & 120,9 & 93,4 & $-0,9$ & 33,7 \\
\hline 101,6 & 80,1 & 4,5 & 32,4 & 104,5 & 80,6 & 0,1 & 31,9 \\
\hline 111,4 & 88,3 & 2,8 & 31,2 & 113,4 & 90,6 & 0,4 & 31,5 \\
\hline 107,7 & 88 & 4,6 & 22,4 & 111,3 & 90,1 & 1 & 23,3 \\
\hline 107,1 & 88,4 & 4 & 29,4 & 115,3 & 90,3 & $-3,9$ & 34,3 \\
\hline 108,3 & 88,8 & 1,9 & 27,7 & 113,1 & 92,6 & 0,6 & 27,5 \\
\hline 100,4 & 84 & 8,4 & 20,4 & 101,2 & 84,9 & 5,5 & 20,8 \\
\hline 107,6 & 83 & 8,7 & 16,1 & 114,4 & 89,1 & 6,4 & 20,3 \\
\hline 104,3 & 86 & 5,8 & 19,9 & 107,3 & 85,7 & 0,7 & 20,7 \\
\hline 114,2 & 87,9 & 4,5 & 28,1 & 112,6 & 86,6 & 5,4 & 28,8 \\
\hline 113,4 & 94,7 & 7,6 & 31,9 & 120,7 & 99 & 2,1 & 30,7 \\
\hline 107,3 & 81,7 & 8,4 & 27,2 & 114,9 & 85,2 & 4,6 & 29 \\
\hline 104,1 & 88,1 & 8,4 & 29,4 & 101,9 & 86,4 & 4,3 & 32,6 \\
\hline 110,2 & 89,8 & 5,4 & 26,3 & 112,5 & 88,5 & 4,6 & 24,8 \\
\hline 105 & 86,7 & 1,3 & 31,8 & 108,6 & 85,2 & $-0,3$ & 30,5 \\
\hline 106,8 & 83,8 & 0 & 31,1 & 110,1 & 83,2 & $-0,1$ & 30,8 \\
\hline 102,9 & 81 & 8,2 & 29,1 & 106,7 & 82 & 6 & 29,7 \\
\hline 110,8 & 91,4 & $-0,4$ & 34,7 & 115,4 & 91,4 & 2,5 & 29,4 \\
\hline 98,3 & 83,9 & 3,4 & 25,6 & 106,1 & 88,4 & 0,8 & 26,9 \\
\hline
\end{tabular}




\begin{tabular}{c|c|c|c|c|c|c|c}
\hline \multicolumn{9}{|c}{$\mathrm{T} 1$} & \multicolumn{3}{c}{$\mathrm{T} 2$} \\
\hline PoOr.PO & ENA-Me & N-Me & S-Go & PoOr.PO & ENA-Me & N-Me & S-Go \\
\hline 8,7 & 70,5 & 120,9 & 76 & 11,2 & 73,7 & 127,7 & 84 \\
\hline 6 & 82 & 128,8 & 77,3 & 4,5 & 82,3 & 130,1 & 79,7 \\
\hline 5,3 & 68 & 111,5 & 62,1 & 11,6 & 68,4 & 114,5 & 67,1 \\
\hline 6,8 & 64,5 & 113,5 & 71,6 & 5,3 & 69,3 & 124,1 & 78,3 \\
\hline 6,6 & 72,5 & 115,6 & 68,6 & 5,7 & 71,8 & 116,5 & 70,1 \\
\hline 2,7 & 66,7 & 110,8 & 65,3 & 4,8 & 66,4 & 112,3 & 65,3 \\
\hline 6,7 & 69,6 & 126,5 & 75,5 & 7 & 75,8 & 135,9 & 79,3 \\
\hline 7,5 & 71,7 & 115 & 71,8 & 13,6 & 73,1 & 118,9 & 73,3 \\
\hline 8,4 & 67,4 & 119,2 & 65,8 & 12,6 & 68,2 & 121,6 & 66,9 \\
\hline 3,9 & 63,5 & 110,5 & 72,3 & 7,2 & 65,6 & 114,1 & 75,6 \\
\hline 9,9 & 69,5 & 114,2 & 66,7 & 14,2 & 71,4 & 121,1 & 70,5 \\
\hline 7,8 & 65,8 & 116,3 & 67,6 & 10,8 & 66,2 & 119,5 & 69,7 \\
\hline 0 & 60,5 & 103,7 & 66,7 & 1,1 & 58,8 & 105,5 & 70,4 \\
\hline$-0,9$ & 63,9 & 112 & 68,4 & 1,5 & 68,6 & 118,9 & 72,9 \\
\hline 6,6 & 61,4 & 113,2 & 70,9 & 8,7 & 62,5 & 117,5 & 74 \\
\hline 10,5 & 69,2 & 118,1 & 71,5 & 8,6 & 70 & 120,7 & 75,6 \\
\hline 5,7 & 74,7 & 115,1 & 68,1 & 7,8 & 75,7 & 126,8 & 72,1 \\
\hline 3,6 & 67,2 & 114,7 & 67,2 & 9,1 & 69,7 & 118,1 & 72,4 \\
\hline 4,3 & 70,3 & 117,2 & 68,5 & 8,7 & 72,1 & 120,4 & 70 \\
\hline 8,4 & 69,5 & 117,7 & 71,3 & 7,3 & 71,1 & 122,5 & 74,1 \\
\hline 11,1 & 69,1 & 118,6 & 65,6 & 16,7 & 67,6 & 121,2 & 67,8 \\
\hline 5,2 & 65,9 & 112,9 & 64,4 & 7,5 & 68,6 & 117,4 & 66,6 \\
\hline 8,9 & 65,4 & 109,4 & 64,5 & 9,8 & 67,3 & 113,3 & 69 \\
\hline 10,1 & 66,7 & 116,2 & 69,8 & 4,9 & 68,6 & 121,9 & 72,9 \\
\hline 12,4 & 63,8 & 105,3 & 69,2 & 11,5 & 67,8 & 111,2 & 70,7 \\
\hline
\end{tabular}




\begin{tabular}{c|c|c|c|c|c|c|c}
\hline \multicolumn{7}{c|}{ T1 } & \multicolumn{3}{c}{ T2 } \\
\hline $1 . P P$ & $1 . N A$ & 1 -NA & $1 . N B$ & $1 . P P$ & $1 . N A$ & 1 -NA & $1 . \mathrm{NB}$ \\
\hline 108,8 & 21,1 & 1,6 & 25,9 & 106,1 & 20 & 2 & 27 \\
\hline 109,2 & 29 & 7,4 & 30,5 & 110,9 & 28,9 & 5 & 29,6 \\
\hline 106,5 & 17,7 & 2,1 & 25 & 108,9 & 20,2 & 3 & 30,5 \\
\hline 115,6 & 28,2 & 5,9 & 28,7 & 117,1 & 29 & 7,5 & 24,4 \\
\hline 107,2 & 20,7 & 4,1 & 32,6 & 106,3 & 19,4 & 1,4 & 29,5 \\
\hline 116,1 & 28,7 & 5,2 & 25,8 & 114,4 & 27,3 & 6,4 & 23,8 \\
\hline 115 & 24,6 & 6,5 & 23,8 & 120,7 & 30,3 & 9,4 & 24 \\
\hline 115,3 & 34,4 & 7,8 & 28,4 & 112,4 & 30,3 & 6 & 21 \\
\hline 116,2 & 27,3 & 4,7 & 38,5 & 110,8 & 22,9 & 4 & 32,8 \\
\hline 108,8 & 20 & 1,6 & 26,8 & 110,8 & 21,8 & 1,7 & 24,5 \\
\hline 107,8 & 13,5 & $-0,9$ & 40,6 & 111,3 & 15,8 & 1,1 & 37,6 \\
\hline 107 & 17,8 & 2,7 & 23 & 105,5 & 15,9 & 1,5 & 22 \\
\hline 117,5 & 32,4 & 7 & 18,4 & 117,3 & 33,1 & 7,5 & 17,5 \\
\hline 115,1 & 30,5 & 7,6 & 26,8 & 112 & 27,4 & 6,8 & 24,3 \\
\hline 111,5 & 23 & 3,5 & 25,2 & 115,9 & 26,8 & 4,5 & 22,9 \\
\hline 106,2 & 20,9 & 5,1 & 30,6 & 107 & 23,2 & 6,9 & 32 \\
\hline 117 & 22,8 & 5,1 & 42,6 & 114,8 & 17,6 & 3 & 40,6 \\
\hline 115,7 & 33,5 & 7,9 & 24,6 & 113 & 28,5 & 6,3 & 23,2 \\
\hline 115,6 & 26,6 & 5,7 & 38,5 & 113,6 & 24,3 & 4,8 & 37,2 \\
\hline 97,8 & 12,6 & 2,3 & 28,9 & 100,7 & 18 & 7,2 & 22,6 \\
\hline 117,3 & 25,4 & 6,8 & 41,2 & 116 & 26,2 & 7,9 & 34,9 \\
\hline 121,9 & 29,6 & 7,2 & 39,1 & 119,5 & 28,9 & 7 & 36,6 \\
\hline 113,9 & 29,4 & 7 & 25,4 & 113,6 & 29,4 & 7,3 & 23,7 \\
\hline 111,8 & 21,9 & 1,4 & 25,9 & 114,6 & 24,1 & 4 & 29,2 \\
\hline 113,2 & 22,2 & 5,8 & 44,5 & 113,4 & 19,5 & 3,7 & 40,7 \\
\hline
\end{tabular}




\begin{tabular}{c|c|c|c|c|c|c|c}
\hline \multicolumn{5}{|c|}{$\mathrm{T} 1$} & \multicolumn{3}{c}{$\mathrm{T} 2$} \\
\hline 1 -NB & $1 . \mathrm{GoMe}$ & $\underline{6}-\mathrm{PP}$ & 6 -GoMe & 1 -NB & $1 . \mathrm{GoMe}$ & $\underline{6}-\mathrm{PP}$ & 6 -GoMe \\
\hline 5,4 & 96,8 & 20,9 & 30,6 & 5,6 & 97,7 & 20,7 & 33,3 \\
\hline 8,1 & 92,1 & 24,7 & 31,4 & 8,3 & 93,1 & 24,9 & 32,3 \\
\hline 4,4 & 90,6 & 20,5 & 25,7 & 6,7 & 94,1 & 20,5 & 28,8 \\
\hline 4,3 & 98,4 & 19,7 & 27,4 & 3,5 & 94,3 & 23,2 & 30 \\
\hline 5,5 & 96,7 & 21,8 & 27,6 & 5,4 & 93,6 & 20,4 & 28,9 \\
\hline 4,3 & 90 & 20,8 & 26,6 & 4,9 & 87 & 19,2 & 27,7 \\
\hline 6,9 & 86 & 23 & 31,4 & 7 & 84,3 & 25 & 34,6 \\
\hline 6 & 96,6 & 22,1 & 28,3 & 4,9 & 91,6 & 20,5 & 29,8 \\
\hline 6,3 & 99,5 & 20,8 & 26,1 & 5,2 & 96,3 & 19,7 & 27,5 \\
\hline 5,1 & 97 & 20,1 & 27,2 & 4,3 & 96,6 & 22,2 & 29,2 \\
\hline 8,7 & 103,6 & 20,1 & 28,4 & 8,7 & 99,4 & 22 & 30,4 \\
\hline 4,7 & 90 & 20,8 & 27,4 & 4 & 89,9 & 19,1 & 29,3 \\
\hline 1,6 & 90,4 & 17,7 & 23,5 & 2,6 & 92,1 & 18,1 & 24,4 \\
\hline 4,4 & 100,3 & 21,5 & 26,6 & 4,2 & 96,1 & 23,1 & 28,5 \\
\hline 4,8 & 96,9 & 16,7 & 30 & 4,3 & 96,4 & 17,5 & 31,5 \\
\hline 7,4 & 97,6 & 21,4 & 29,2 & 7,2 & 97,4 & 22,6 & 30,2 \\
\hline 9,2 & 100,2 & 22,6 & 31,9 & 11,1 & 100,6 & 23,2 & 34,3 \\
\hline 5,4 & 91,5 & 19,5 & 26 & 5,1 & 88,6 & 20,3 & 28,8 \\
\hline 11 & 101,8 & 20 & 28,8 & 9,6 & 100,8 & 19,4 & 31,2 \\
\hline 5,8 & 98,4 & 21,4 & 29,2 & 5,6 & 92,6 & 22,7 & 30,9 \\
\hline 10,2 & 104,6 & 21,3 & 29,7 & 10,1 & 100,4 & 17,3 & 31,4 \\
\hline 8 & 100,7 & 23,2 & 25 & 7,5 & 98,6 & 22,9 & 27,7 \\
\hline 4,9 & 88,6 & 16,1 & 29,1 & 4,3 & 87,6 & 17,9 & 30 \\
\hline 4,2 & 89,6 & 19 & 28,3 & 5,4 & 93,3 & 22,3 & 29,6 \\
\hline 11,2 & 114 & 17,4 & 30,8 & 12,4 & 108,1 & 20,4 & 31,9 \\
\hline
\end{tabular}




\begin{tabular}{c|c|c|c|c|c|c|c}
\hline \multicolumn{5}{c|}{ T1 } & \multicolumn{3}{c}{ T2 } \\
\hline 1 -PP & 1 -GoMe & 6-SperpPO & 6 -SperpPO & 1-PP & 1 -GoMe & $\underline{6}$-SperpPO & 6 -SperpPO \\
\hline 29,8 & 41,8 & 48,3 & 45,6 & 32,4 & 44,2 & 49,2 & 50,9 \\
\hline 36,1 & 47,6 & 50,7 & 48,2 & 36,7 & 47,8 & 49,6 & 51,3 \\
\hline 28,9 & 38,5 & 46,8 & 44,4 & 30,7 & 39,3 & 49,5 & 51,2 \\
\hline 28,1 & 39,8 & 50,4 & 48,6 & 29,5 & 42,6 & 52,2 & 53,4 \\
\hline 30,1 & 40 & 45,6 & 44,1 & 29,8 & 41,3 & 44,9 & 47,3 \\
\hline 26,8 & 38,4 & 48,8 & 47,6 & 28,8 & 40,4 & 48,3 & 52,9 \\
\hline 30,7 & 43,7 & 53,3 & 53,3 & 31,7 & 47,7 & 55,6 & 59,5 \\
\hline 29,5 & 39,9 & 42,8 & 38,6 & 30,1 & 40,3 & 43 & 42,9 \\
\hline 30 & 40,2 & 49,6 & 51,5 & 31,1 & 39,1 & 48,1 & 55,3 \\
\hline 27,3 & 39 & 53,5 & 52,1 & 29,2 & 39,3 & 54,1 & 55 \\
\hline 30,9 & 41,4 & 55,7 & 53,8 & 31,3 & 43,1 & 51,9 & 56,9 \\
\hline 29,1 & 40,5 & 51,4 & 49,5 & 30,1 & 41,5 & 50,7 & 53,6 \\
\hline 25,7 & 36,8 & 38,1 & 35,9 & 26,7 & 38,1 & 36,4 & 37,7 \\
\hline 26,5 & 36,6 & 43,7 & 43,3 & 30,4 & 40,5 & 44,3 & 47 \\
\hline 27 & 39 & 48,7 & 47,8 & 26,1 & 40 & 47,9 & 50,1 \\
\hline 32,5 & 40,5 & 58,1 & 57,5 & 32,7 & 41,4 & 58,1 & 59,1 \\
\hline 31,5 & 43,6 & 57,8 & 56,3 & 31,1 & 46,6 & 58,1 & 61,4 \\
\hline 29,6 & 41,1 & 43,4 & 40,7 & 31,5 & 41 & 45,9 & 48,1 \\
\hline 30,5 & 43 & 47,3 & 45,4 & 31 & 44,6 & 46,7 & 47,4 \\
\hline 32,4 & 41,3 & 48,2 & 46,3 & 33,5 & 43,4 & 46,6 & 48,7 \\
\hline 30,7 & 42 & 54 & 52,1 & 31,4 & 42 & 52,2 & 57,9 \\
\hline 28,3 & 40,9 & 46,3 & 45,2 & 29,2 & 42,2 & 49,2 & 51,5 \\
\hline 26,4 & 37,1 & 52,6 & 52 & 28,2 & 38 & 53 & 54,5 \\
\hline 26,7 & 39,9 & 52,7 & 50,6 & 27,3 & 40,2 & 52,9 & 53,3 \\
\hline 29,8 & 39,4 & 51,5 & 49 & 30,7 & 41,9 & 51,6 & 53,6 \\
\hline & & & & & & & \\
\hline
\end{tabular}




\begin{tabular}{c|c|c|c|c|c|c|c}
\hline \multicolumn{5}{c}{$\mathrm{T} 1$} & \multicolumn{3}{c}{ T2 } \\
\hline 1-SperpPO & 1 -SperpPo & 6.PP & 6. GoMe & 1-SperpPO & 1 -SperpPo & 6.PP & $6 . \mathrm{GoMe}$ \\
\hline 81,5 & 75,1 & $-102,1$ & $-82,8$ & 83,2 & 79,4 & $-104,4$ & $-84,5$ \\
\hline 86,4 & 79,4 & $-112,9$ & $-76,4$ & 86,5 & 81 & $-112,8$ & $-76,2$ \\
\hline 80,1 & 73 & $-111,9$ & $-83,7$ & 83,1 & 79,5 & $-105,6$ & $-77,3$ \\
\hline 82,5 & 76,8 & $-106,9$ & $-85,6$ & 86,7 & 80 & $-102,5$ & $-79,9$ \\
\hline 78,7 & 71,3 & $-109,8$ & $-79,3$ & 78,1 & 73,1 & $-115,7$ & $-80,1$ \\
\hline 81,2 & 73,4 & $-106,3$ & $-85,5$ & 83,7 & 78,1 & $-115,5$ & $-82,3$ \\
\hline 84,6 & 77,8 & $-97,1$ & $-75,6$ & 88,5 & 80,8 & $-98,5$ & $-75,8$ \\
\hline 78,2 & 68,3 & $-112,7$ & $-81,2$ & 78,8 & 71,2 & $-114,8$ & $-76,6$ \\
\hline 82,7 & 78,8 & $-109,9$ & $-79,6$ & 82,7 & 79,1 & $-118,7$ & $-86,7$ \\
\hline 81,7 & 77,3 & $-98,4$ & $-84,8$ & 83,2 & 78,8 & $-99,9$ & $-85,8$ \\
\hline 88,2 & 83,1 & $-105,9$ & $-80,5$ & 88 & 84,5 & $-110,3$ & $-78,8$ \\
\hline 81,4 & 75,5 & $-102,6$ & -83 & 83 & 78 & $-108,1$ & $-82,1$ \\
\hline 75,1 & 62,5 & $-111,8$ & $-82,9$ & 74,8 & 64 & $-117,3$ & $-85,2$ \\
\hline 77,5 & 70,6 & $-106,8$ & $-87,2$ & 80 & 73,2 & $-107,4$ & $-80,5$ \\
\hline 80 & 73,3 & $-106,6$ & $-89,4$ & 80,4 & 74,6 & -99 & $-83,6$ \\
\hline 88,8 & 84,3 & $-101,8$ & -80 & 89,2 & 84,7 & $-107,9$ & $-78,6$ \\
\hline 94,1 & 83,3 & $-108,7$ & $-81,5$ & 95,5 & 88,5 & $-109,4$ & $-77,6$ \\
\hline 77,3 & 68,7 & $-112,9$ & -84 & 79,3 & 73,6 & $-108,7$ & $-78,2$ \\
\hline 84,2 & 75,5 & $-112,4$ & $-89,2$ & 84,6 & 75,7 & $-116,1$ & $-89,9$ \\
\hline 80,2 & 74,8 & $-106,3$ & $-84,5$ & 80 & 75,6 & $-108,9$ & $-82,3$ \\
\hline 88,8 & 80,3 & -106 & $-79,2$ & 88,8 & 83,3 & $-88,5$ & $-79,7$ \\
\hline 81,3 & 75,5 & $-103,6$ & $-79,4$ & 83,2 & 79,2 & $-96,3$ & $-78,2$ \\
\hline 84,9 & 76,6 & $-104,5$ & $-79,4$ & 85,2 & 77,2 & $-98,9$ & $-82,3$ \\
\hline 82,6 & 75,1 & $-103,5$ & $-81,6$ & 85,4 & 77,5 & $-105,5$ & $-81,7$ \\
\hline 85,6 & 78,9 & $-105,7$ & $-90,3$ & 85,9 & 82,4 & -106 & $-85,4$ \\
\hline & & & & & & &
\end{tabular}


\begin{tabular}{l|l|l|l|l|l}
\hline sobressaliência & relação molar & ângulo nasolabial & sobressaliência & relação molar & ângulo nasolabial \\
\hline
\end{tabular}

\begin{tabular}{c|c|c|c|c|c}
\hline 6,4 & 1,7 & 116,2 & 3,8 & $-2,8$ & 121,9 \\
\hline 7 & 1,4 & 93,5 & 5,5 & -3 & 105,7 \\
\hline 7,1 & 0,7 & 97,1 & 3,6 & -3 & 93,3 \\
\hline 5,7 & $-0,3$ & 97,5 & 6,7 & $-2,5$ & 97,9 \\
\hline 7,4 & $-0,1$ & 117,5 & 5 & $-4,1$ & 103,2 \\
\hline 7,8 & $-0,5$ & 103,6 & 5,6 & $-6,1$ & 107,5 \\
\hline 6,8 & $-1,5$ & 106,7 & 7,7 & $-5,5$ & 99,3 \\
\hline 9,9 & 2,1 & 113,6 & 7,6 & $-2,7$ & 111,1 \\
\hline 3,9 & -4 & 126,2 & 3,6 & $-9,3$ & 121,5 \\
\hline 4,4 & 0,3 & 100,1 & 4,4 & $-2,1$ & 99,3 \\
\hline 5,1 & $-0,2$ & 104,2 & 3,5 & $-6,3$ & 117,3 \\
\hline 5,9 & 0,7 & 117,5 & 5 & $-4,6$ & 109,9 \\
\hline 12,6 & 0,6 & 111 & 10,8 & -3 & 112,6 \\
\hline 6,9 & $-1,3$ & 108,5 & 6,8 & $-4,3$ & 110,5 \\
\hline 6,7 & $-0,9$ & 95,4 & 5,8 & $-3,5$ & 104,9 \\
\hline 4,5 & $-0,7$ & 93,5 & 4,5 & $-2,7$ & 87,2 \\
\hline 10,8 & $-0,5$ & 94 & 7 & $-5,2$ & 93,3 \\
\hline 8,6 & 1,3 & 96,9 & 5,7 & $-3,8$ & 99 \\
\hline 8,7 & $-0,2$ & 115,5 & 8,9 & $-3,7$ & 119,5 \\
\hline 5,4 & 1 & 106,3 & 4,4 & $-3,7$ & 100 \\
\hline 8,5 & $-0,6$ & 99,7 & 5,5 & $-4,1$ & 103,5 \\
\hline 5,8 & $-0,7$ & 104,7 & 4 & $-3,8$ & 103,8 \\
\hline 8,3 & $-0,8$ & 125,9 & 8 & $-2,8$ & 124,6 \\
\hline 7,5 & 0 & 130,1 & 7,9 & $-2,5$ & 114,8 \\
\hline 6,7 & 0,6 & 112,2 & 3,5 & $-4,2$ & 99,7 \\
\hline
\end{tabular}




\begin{tabular}{|c|c|c|c|}
\hline \multicolumn{2}{|c|}{ T1 } & \multicolumn{2}{|c|}{$\mathrm{T} 2$} \\
\hline Ls-PrnPog' & Li-PrnPog' & Ls-PrnPog' & Li-PrnPog' \\
\hline$-1,5$ & 2,7 & $-1,8$ & 1,7 \\
\hline 1,4 & 1,9 & $-0,7$ & 3,4 \\
\hline 3,1 & 6,4 & 0,5 & 6 \\
\hline$-0,1$ & 0,9 & $-2,8$ & 0,8 \\
\hline 0,1 & 1,5 & $-1,9$ & 0,9 \\
\hline 0,7 & 2,6 & -1 & 1,8 \\
\hline$-0,5$ & 4,1 & $-1,4$ & 3,7 \\
\hline 1,1 & 4,1 & $-1,7$ & 1,8 \\
\hline$-1,5$ & 0,7 & $-3,9$ & $-0,5$ \\
\hline 1,7 & 2,6 & 0,1 & 2,4 \\
\hline 1,2 & 2,9 & $-0,8$ & 2,4 \\
\hline 1,3 & 2,9 & $-0,1$ & 0,9 \\
\hline 2 & 1,1 & 0,4 & 3,4 \\
\hline 2,1 & 3,2 & 0,5 & 2,2 \\
\hline$-1,8$ & $-0,4$ & $-2,5$ & 0 \\
\hline 0,3 & 3,9 & $-1,6$ & 3,7 \\
\hline 4,9 & 5,5 & 4,8 & 6,2 \\
\hline 3,2 & 2,4 & 1 & 1,7 \\
\hline 3,6 & 6 & 4,3 & 4 \\
\hline$-1,2$ & 3,2 & -3 & 1,7 \\
\hline 3,1 & 7,7 & $-0,9$ & 5,7 \\
\hline 0,7 & 5,3 & $-2,3$ & 3,3 \\
\hline 0,1 & 3,9 & $-0,5$ & 1,9 \\
\hline$-1,4$ & 1,4 & $-2,4$ & 0,4 \\
\hline 5,4 & 9,7 & 5,7 & 9,9 \\
\hline
\end{tabular}




\section{Grupo Controle 2}

\begin{tabular}{|c|c|c|c|c|c|c|c|}
\hline \multicolumn{4}{|c|}{ T1 } & \multicolumn{4}{|c|}{$\mathrm{T} 2$} \\
\hline S.N.A & S.N.B & A.N.B & N.A.Pog & S.N.A & S.N.B & A.N.B & N.A.Pog \\
\hline 88,8 & 82,7 & 6 & 11,8 & 90,2 & 83,3 & 6,9 & 13,2 \\
\hline 82,8 & 76,4 & 6,4 & 11,3 & 83,9 & 77,7 & 6,1 & 10,1 \\
\hline 83,5 & 80,3 & 3,2 & 4,5 & 87,5 & 83,8 & 3,6 & 5,5 \\
\hline 78,6 & 72,2 & 6,3 & 9,3 & 78,6 & 72,4 & 6,2 & 9,3 \\
\hline 81,3 & 80,2 & 1 & 2 & 81,3 & 80,6 & 0,5 & 0,8 \\
\hline 88,8 & 81,9 & 6,8 & 12 & 89 & 82,9 & 6,1 & 11,1 \\
\hline 82,7 & 78,3 & 4,3 & 6,9 & 83 & 78,9 & 4 & 5,9 \\
\hline 83,4 & 77,6 & 5,8 & 5,8 & 84,7 & 78,3 & 6,4 & 7,7 \\
\hline 82,3 & 81,3 & 0,9 & $-1,2$ & 82,4 & 80,6 & 1,7 & $-0,3$ \\
\hline 80,6 & 76,7 & 3,9 & 6,7 & 84,3 & 80 & 4,3 & 7 \\
\hline 76 & 73,7 & 2,3 & 0,8 & 77,3 & 74,7 & 2,6 & 1,4 \\
\hline 80,1 & 76,1 & 4 & 5,3 & 79,8 & 76,1 & 3,7 & 4 \\
\hline 87 & 80,7 & 6,2 & 10,4 & 87,3 & 81 & 6,1 & 9,6 \\
\hline 76 & 74,4 & 1,6 & 0,2 & 77 & 74,9 & 2 & 1,5 \\
\hline 79,5 & 76,7 & 2,7 & 2,7 & 79,5 & 76,7 & 2,7 & 1,5 \\
\hline 75,4 & 72,5 & 2,8 & 2,3 & 75,2 & 73,4 & 1,8 & 0 \\
\hline 78,8 & 73,7 & 5,1 & 9 & 79,2 & 73,8 & 5,3 & 8,5 \\
\hline 78,4 & 74,5 & 3,8 & 5,6 & 79,3 & 75 & 4,1 & 6 \\
\hline 79 & 76,1 & 2,8 & 3 & 79 & 76,7 & 2,2 & 1,6 \\
\hline 73,5 & 70,6 & 3 & 5,9 & 74 & 71 & 3 & 5,9 \\
\hline 77,6 & 71,4 & 6,2 & 9,8 & 78,7 & 72,1 & 6,7 & 10,2 \\
\hline 82,5 & 77,5 & 5 & 9,9 & 81,1 & 76,8 & 4,2 & 7,9 \\
\hline 76,4 & 72,9 & 3,5 & 6 & 77,6 & 73,3 & 4,2 & 7,4 \\
\hline 77,6 & 74,1 & 3,5 & 4,1 & 77,9 & 74,1 & 3,8 & 5,1 \\
\hline 79,4 & 75,5 & 3,8 & 5,7 & 79,8 & 76,1 & 3,7 & 5,3 \\
\hline 80,2 & 73,9 & 6,2 & 8,9 & 80,2 & 75,1 & 5 & 5,5 \\
\hline 76 & 71,7 & 4,3 & 7,5 & 76,5 & 72,5 & 3,9 & 6,6 \\
\hline 77,8 & 72,6 & 5,1 & 10,1 & 77,8 & 73,4 & 4,3 & 8 \\
\hline 85,4 & 80 & 5,3 & 9,1 & 85 & 79,2 & 5,7 & 10,1 \\
\hline 79 & 78,1 & 0,9 & 1,2 & 79,9 & 78,5 & 1,3 & 2,5 \\
\hline 84,9 & 79,5 & 5,3 & 6,7 & 84,9 & 79,6 & 5,2 & 5,9 \\
\hline
\end{tabular}




\begin{tabular}{|c|c|c|c|c|c|c|c|}
\hline \multicolumn{4}{|c|}{ T1 } & \multicolumn{4}{|c|}{$\mathrm{T} 2$} \\
\hline Co-Gn & Co-A & PoOr.PP & PoOr.GoMe & Co-Gn & Co-A & PoOr.PP & PoOr.GoMe \\
\hline 119,3 & 96,8 & $-1,5$ & 17,3 & 121,3 & 97,8 & $-0,7$ & 16,7 \\
\hline 108,4 & 88,1 & 2,7 & 24,7 & 111,6 & 89,7 & 2 & 25,5 \\
\hline 106,7 & 86,8 & 4,8 & 19,8 & 109,2 & 88,6 & 4,3 & 19,9 \\
\hline 107,3 & 86 & 0,1 & 22,8 & 110,3 & 88,3 & 2,6 & 21 \\
\hline 108,7 & 87,2 & 1,8 & 21,3 & 115,6 & 92,3 & 1,4 & 20,5 \\
\hline 106,9 & 86,8 & 0,8 & 20,7 & 109,4 & 87,5 & 0 & 21,9 \\
\hline 105,7 & 78,9 & 1,1 & 34,1 & 108,3 & 79,8 & $-0,2$ & 34,4 \\
\hline 111,8 & 84,5 & $-1,4$ & 27,2 & 114,2 & 86,7 & $-1,9$ & 27,3 \\
\hline 114,5 & 87,4 & 8,4 & 15,7 & 117,3 & 89,9 & 7,6 & 15,3 \\
\hline 103 & 82,2 & 3,6 & 23,4 & 105,9 & 83,8 & 3,4 & 22,5 \\
\hline 104,1 & 84,3 & 5 & 22,5 & 109,2 & 88 & 4,5 & 21,3 \\
\hline 111,2 & 89,5 & $-2,7$ & 23,6 & 114,7 & 91,1 & $-1,1$ & 23,6 \\
\hline 110,1 & 88,3 & 5,8 & 17,2 & 113,9 & 91,1 & 6,1 & 16,7 \\
\hline 107,8 & 86,7 & 2,2 & 19,9 & 110,9 & 89,6 & 1,8 & 19,2 \\
\hline 113,6 & 89,4 & 0,3 & 23,8 & 116 & 90,9 & $-2,4$ & 25,1 \\
\hline 108,1 & 82,7 & 2,9 & 24,6 & 112,8 & 85 & 1,8 & 25 \\
\hline 111,3 & 91,1 & 5,4 & 21 & 114,6 & 93,1 & 4,6 & 21,8 \\
\hline 112,7 & 91,4 & 1,8 & 25,2 & 116 & 93,2 & $-0,6$ & 27,1 \\
\hline 107,7 & 85,2 & 6,8 & 20,1 & 111,9 & 87,8 & 6,4 & 19,1 \\
\hline 105,7 & 82,2 & 2,7 & 28,7 & 108,7 & 84,6 & 1,1 & 29,6 \\
\hline 109,1 & 88,5 & $-0,4$ & 27,4 & 112,5 & 92,3 & -1 & 27,1 \\
\hline 113,1 & 93,3 & 3,4 & 19,4 & 116,6 & 94,7 & 4,6 & 19,6 \\
\hline 108,4 & 90 & 3,4 & 24,7 & 112 & 93,7 & 3,2 & 23,1 \\
\hline 105 & 81,9 & 3,8 & 24,1 & 107,9 & 84,4 & 7 & 20,9 \\
\hline 107,2 & 87,2 & 1,6 & 22 & 107,8 & 87,2 & 2,2 & 20,9 \\
\hline 106,9 & 85 & 2,1 & 24,4 & 110,9 & 86,7 & 5,2 & 19,5 \\
\hline 109,3 & 87,6 & 2,4 & 26,5 & 111,5 & 89,4 & 1,2 & 25,4 \\
\hline 104,8 & 88,4 & 0,5 & 25,2 & 108,6 & 89,9 & $-0,6$ & 25,9 \\
\hline 108,4 & 89,7 & $-0,8$ & 22,2 & 110,3 & 91,7 & $-0,5$ & 21,8 \\
\hline 106,8 & 85,6 & 6,9 & 16,2 & 108,2 & 87,1 & 6,1 & 15 \\
\hline 116,1 & 94,8 & 5,9 & 19,3 & 119,6 & 98 & 6 & 16,7 \\
\hline
\end{tabular}




\begin{tabular}{|c|c|c|c|c|c|c|c|}
\hline \multicolumn{4}{|c|}{$\mathrm{T} 1$} & \multicolumn{4}{|c|}{$\mathrm{T} 2$} \\
\hline PoOr.PO & ENA-Me & $\mathrm{N}-\mathrm{Me}$ & S-Go & PoOr.PO & ENA-Me & $\mathrm{N}-\mathrm{Me}$ & S-Go \\
\hline 7,5 & 63,2 & 113,3 & 79,9 & 6,3 & 66,1 & 116,6 & 82,3 \\
\hline 6,7 & 63,6 & 107,6 & 65,4 & 5,9 & 64,3 & 110 & 67,3 \\
\hline 8,4 & 54,1 & 98,4 & 62,7 & 8,3 & 55,4 & 98,3 & 65,4 \\
\hline 10,6 & 65,1 & 115,9 & 74 & 9,3 & 66,5 & 119,1 & 77,3 \\
\hline 5,3 & 59,4 & 108 & 73,6 & 4,5 & 60,7 & 111,5 & 77 \\
\hline 5,7 & 58 & 102,1 & 68,9 & 6,1 & 60,6 & 106,2 & 71,4 \\
\hline 13,8 & 67,9 & 113 & 65,9 & 14,1 & 69,4 & 115,8 & 68,8 \\
\hline 14,1 & 62,3 & 114,2 & 72 & 13,1 & 63,5 & 117,1 & 74,5 \\
\hline$-1,8$ & 60,2 & 109 & 72 & $-1,9$ & 61,7 & 112,4 & 74,6 \\
\hline 9,2 & 61 & 106,6 & 69 & 8,6 & 61 & 106 & 71,9 \\
\hline 6,8 & 56,4 & 101,8 & 60,6 & 4,8 & 58,2 & 104,9 & 64,4 \\
\hline 13,2 & 58,2 & 113,5 & 73 & 13 & 60,8 & 116,8 & 74,9 \\
\hline 1,1 & 62 & 107 & 73,4 & 0,3 & 63,3 & 108,8 & 75,9 \\
\hline 6,4 & 63,2 & 112,5 & 74,3 & 4,3 & 64,6 & 115,1 & 75,9 \\
\hline 9,3 & 61,7 & 111,7 & 71,1 & 10,9 & 62,6 & 114,3 & 74,5 \\
\hline 11 & 65,6 & 117,1 & 74 & 12,1 & 66,6 & 120,8 & 76,7 \\
\hline 4,3 & 65,7 & 113,4 & 68,6 & 3,4 & 67,6 & 117 & 70,3 \\
\hline 9,2 & 65,7 & 116,2 & 75,1 & 10,9 & 68,6 & 120,6 & 78,9 \\
\hline 5,2 & 61,8 & 108,6 & 68 & 4,1 & 62,9 & 111,5 & 71,4 \\
\hline 10 & 61,3 & 115,4 & 64,2 & 11,6 & 62,9 & 118,7 & 66,4 \\
\hline 9,7 & 63,7 & 113,4 & 66,9 & 9,2 & 63,1 & 114,4 & 68 \\
\hline 3,1 & 65,3 & 112,4 & 74,4 & 3,9 & 68,8 & 117,2 & 76,1 \\
\hline 7,6 & 63,1 & 112,9 & 69,9 & 8,6 & 65 & 115,5 & 72,3 \\
\hline 4,3 & 64,1 & 112,3 & 71 & 0,2 & 65,8 & 115,5 & 72,9 \\
\hline 9,6 & 59,9 & 107,8 & 69,4 & 8,2 & 61,4 & 110,7 & 72,4 \\
\hline 1,6 & 63,5 & 108,5 & 66,5 & $-1,7$ & 64,7 & 110,6 & 69,7 \\
\hline 10,9 & 65,6 & 115,6 & 68,6 & 9,5 & 65,1 & 117,3 & 69,5 \\
\hline 8,2 & 60,5 & 110,4 & 68,1 & 8,3 & 62,6 & 114,6 & 70,8 \\
\hline 9,8 & 59 & 106,3 & 72,4 & 8,2 & 59,8 & 108,6 & 74,3 \\
\hline 4,1 & 59,5 & 104,3 & 68,8 & 3,1 & 59 & 106,5 & 70,7 \\
\hline 4,3 & 61,7 & 110,8 & 77 & 2,5 & 62,6 & 114 & 79,5 \\
\hline
\end{tabular}




\begin{tabular}{|c|c|c|c|c|c|c|c|}
\hline \multicolumn{4}{|c|}{$\mathrm{T} 1$} & \multicolumn{4}{|c|}{$\mathrm{T} 2$} \\
\hline 1.PP & 1.NA & 1-NA & 1.NB & 1.PP & 1.NA & 1-NA & 1.NB \\
\hline 112,3 & 14,6 & 2,5 & 31,1 & 112 & 13,9 & 1,8 & 30,3 \\
\hline 116,9 & 26,2 & 4,3 & 26,7 & 117,3 & 25,8 & 4,9 & 25,6 \\
\hline 106,4 & 19,1 & 1,6 & 17,9 & 105,9 & 16,8 & 1,3 & 20,7 \\
\hline 106,6 & 16,9 & 1,7 & 26,4 & 106 & 17,5 & 2,1 & 27,5 \\
\hline 113,2 & 27,1 & 4,4 & 21,4 & 112,2 & 25,7 & 4,5 & 19,5 \\
\hline 122,8 & 27,2 & 3,1 & 40,1 & 119 & 23 & 2,7 & 38,7 \\
\hline 105,7 & 19,5 & 1,2 & 26,1 & 106,7 & 20,2 & 2 & 24,8 \\
\hline 102,6 & 11,6 & $-0,9$ & 25,3 & 101,7 & 8,4 & $-2,1$ & 26,6 \\
\hline 119,8 & 34,3 & 7,4 & 23,2 & 117,8 & 30,8 & 6,6 & 22 \\
\hline 106,5 & 20,7 & 2,8 & 28,8 & 105,5 & 17,8 & 2,2 & 26 \\
\hline 109,2 & 27,6 & 4,3 & 23 & 108,7 & 25,7 & 3,9 & 24 \\
\hline 104,4 & 15,4 & 0,2 & 19,9 & 101,5 & 13,8 & 0,5 & 20,8 \\
\hline 114,8 & 23,8 & 4,4 & 28,3 & 114,8 & 24,7 & 5,2 & 29,2 \\
\hline 106,4 & 22,5 & 2,9 & 24,5 & 105,7 & 19,8 & 2,5 & 25,1 \\
\hline 111,8 & 24,5 & 4,8 & 23,6 & 113,4 & 25,3 & 5,7 & 24,2 \\
\hline 102,2 & 17,5 & 2,2 & 17,8 & 100,9 & 15,3 & 2,4 & 19,7 \\
\hline 112 & 24,2 & 4,4 & 30,6 & 113,5 & 25 & 4,8 & 30,9 \\
\hline 102,1 & 17,5 & 2,7 & 17,2 & 103,3 & 18,2 & 3,1 & 19,1 \\
\hline 108,4 & 24,5 & 4,3 & 21,7 & 107,5 & 23,4 & 4,7 & 21,6 \\
\hline 106,2 & 20,4 & 4,4 & 23,2 & 105,1 & 19,1 & 4,2 & 25,5 \\
\hline 113,6 & 23,2 & 4,3 & 28,7 & 115 & 23,1 & 4 & 31 \\
\hline 116,9 & 28,1 & 4,9 & 26,2 & 115,4 & 28,5 & 6,4 & 28,8 \\
\hline 102,5 & 18,7 & 1,9 & 23,4 & 101 & 15,4 & 0,4 & 21,2 \\
\hline 107,6 & 23,9 & 3,7 & 23,7 & 108,6 & 24,7 & 4,2 & 25,1 \\
\hline 94,6 & 7,8 & 0,6 & 14,7 & 95,1 & 8,4 & 1,1 & 15,6 \\
\hline 116,6 & 27,6 & 4,7 & 27,7 & 114 & 25,3 & 4,5 & 28,2 \\
\hline 101 & 16,7 & 2,1 & 29,1 & 105,1 & 18,6 & 2,4 & 31,7 \\
\hline 116,9 & 30,2 & 3,2 & 31,7 & 119,2 & 32 & 6,7 & 32,5 \\
\hline 114,2 & 22,3 & 0,6 & 22,4 & 115,4 & 23,3 & 1,5 & 23,4 \\
\hline 115,7 & 32,6 & 6,4 & 29,1 & 115,1 & 30,2 & 5,9 & 28,5 \\
\hline 106,1 & 17,9 & 1,7 & 28,5 & 104,5 & 15,7 & 0,7 & 29 \\
\hline
\end{tabular}




\begin{tabular}{c|c|c|c|c|c|c|c}
\hline \multicolumn{7}{|c|}{$\mathrm{T} 1$} & \multicolumn{3}{c}{$\mathrm{T} 2$} \\
\hline $1-\mathrm{NB}$ & $1 . \mathrm{GoMe}$ & $\underline{6}-\mathrm{PP}$ & 6 -GoMe & 1 -NB & $1 . \mathrm{GoMe}$ & $\underline{6}$-PP & 6 -GoMe \\
\hline 6,5 & 103,8 & 21,7 & 31,2 & 6,8 & 103,1 & 23,8 & 32,1 \\
\hline 3,6 & 95 & 19,6 & 27 & 3,7 & 92,7 & 20,4 & 27,4 \\
\hline 1,6 & 89,2 & 16,1 & 23,4 & 2,1 & 91 & 18 & 23,8 \\
\hline 5,8 & 100 & 19,2 & 30,1 & 6 & 101,4 & 19,4 & 31,3 \\
\hline 1,6 & 93 & 18,3 & 27,1 & 1,2 & 91,5 & 19,3 & 28,6 \\
\hline 7,7 & 110 & 17,3 & 27,9 & 7,6 & 107 & 19,1 & 28,9 \\
\hline 3,8 & 88,8 & 18,1 & 28,3 & 4,1 & 88,1 & 19,1 & 29,2 \\
\hline 3 & 94,3 & 18,7 & 27,2 & 3,3 & 94,4 & 20,1 & 27,7 \\
\hline 2,6 & 94,6 & 18,8 & 25,5 & 2,9 & 93,8 & 19,6 & 26,6 \\
\hline 4,5 & 100,8 & 18,1 & 26,9 & 4,4 & 96,5 & 18,8 & 26,6 \\
\hline 2,7 & 96,2 & 16,9 & 22,8 & 2,8 & 97,7 & 18,9 & 23,5 \\
\hline 2,1 & 94 & 18,2 & 26 & 2,6 & 94,4 & 19,5 & 26,3 \\
\hline 5,3 & 100,7 & 20,1 & 27,7 & 6,1 & 102,6 & 21,4 & 28,4 \\
\hline 2,4 & 100 & 21,8 & 28,3 & 2,4 & 100,1 & 24 & 28 \\
\hline 1,5 & 94,9 & 20,1 & 26,1 & 2,2 & 96,2 & 21,2 & 27 \\
\hline 1,3 & 87,6 & 21,7 & 28,6 & 1,9 & 89 & 22,3 & 29 \\
\hline 6,5 & 101,3 & 22,3 & 28 & 7,2 & 101,2 & 23,4 & 28,9 \\
\hline 2,4 & 89,3 & 20,6 & 28,6 & 3,8 & 91,6 & 22,1 & 29 \\
\hline 2,4 & 93,5 & 19,6 & 24,6 & 2,5 & 94 & 21,9 & 25,1 \\
\hline 4,5 & 88,9 & 19,3 & 25,7 & 4,9 & 91,6 & 20,4 & 26,8 \\
\hline 6,3 & 97,4 & 19,8 & 29,3 & 6,8 & 99,5 & 20,1 & 30 \\
\hline 4,6 & 99,6 & 20,8 & 28,5 & 5,3 & 101,8 & 21 & 29,4 \\
\hline 2,8 & 94,9 & 19,1 & 28,6 & 2,4 & 93,5 & 20,2 & 30 \\
\hline 3,7 & 95,5 & 19,7 & 26,9 & 3,9 & 97 & 21,3 & 27,5 \\
\hline 0,6 & 88,1 & 18,3 & 26,3 & 0,5 & 89,3 & 19,7 & 26,8 \\
\hline 4,5 & 98,2 & 20,4 & 27 & 5,3 & 99,5 & 22 & 28,1 \\
\hline 5,4 & 100,2 & 21 & 27,4 & 5,5 & 102,5 & 21,5 & 27,6 \\
\hline 5,1 & 104,4 & 16,7 & 28,1 & 5,4 & 104,4 & 17,7 & 28,9 \\
\hline 3,1 & 94,5 & 16,7 & 27,4 & 4,6 & 95,8 & 18 & 27,4 \\
\hline 3,3 & 103,7 & 17,8 & 26,6 & 3,7 & 103,8 & 18,2 & 26,6 \\
\hline 4 & 101,4 & 18,8 & 26,6 & 3,9 & 102,5 & 20,5 & 26,7 \\
\hline & & & & & & & \\
\hline
\end{tabular}




\begin{tabular}{c|c|c|c|c|c|c|c}
\hline \multicolumn{5}{|c|}{ T1 } & \multicolumn{3}{|c}{ T2 } \\
\hline 1-PP & 1 -GoMe & $\underline{6}$-SperpPO & 6 -SperpPO & 1-PP & 1 -GoMe & 6 -SperpPO & 6 -SperpPO \\
\hline 28 & 40,1 & 59,4 & 57,3 & 29,5 & 41,2 & 61,8 & 59,5 \\
\hline 26 & 36,1 & 47,7 & 47,2 & 26,6 & 37,6 & 48,5 & 48,1 \\
\hline 24,7 & 31,2 & 51,8 & 50,3 & 25,9 & 31,5 & 54,6 & 52,4 \\
\hline 28,8 & 39,9 & 48,7 & 47,7 & 29,8 & 40,6 & 51 & 50,1 \\
\hline 24,7 & 37,6 & 47,8 & 47,6 & 24,9 & 38,4 & 49,8 & 51,5 \\
\hline 21,8 & 37,2 & 49,3 & 48,4 & 23,4 & 38,6 & 52,3 & 51,7 \\
\hline 27,3 & 40,3 & 48,3 & 46,6 & 27,7 & 40,9 & 49,5 & 48,3 \\
\hline 27,1 & 35,6 & 54,6 & 53,8 & 27,7 & 36,1 & 54,8 & 55,2 \\
\hline 23,8 & 36,7 & 41,7 & 42,2 & 24,4 & 38,2 & 43,2 & 43,9 \\
\hline 25,8 & 35,3 & 47,9 & 46,4 & 26,8 & 35,4 & 48,5 & 47 \\
\hline 25,7 & 33,1 & 45,5 & 44,8 & 26,4 & 34,2 & 46,8 & 45,9 \\
\hline 26,6 & 34,8 & 52,3 & 49,5 & 29 & 35,3 & 54,7 & 52,6 \\
\hline 26,7 & 39,3 & 46,6 & 44,7 & 27,6 & 40 & 48,9 & 47,1 \\
\hline 28,4 & 37,1 & 50 & 49,6 & 29,8 & 38 & 50,5 & 50,4 \\
\hline 28,6 & 37 & 50,6 & 49,2 & 28,9 & 37,4 & 51,6 & 50,2 \\
\hline 29,4 & 36 & 51,4 & 48,1 & 30,5 & 36,9 & 54,3 & 51,8 \\
\hline 30,5 & 39,1 & 53,8 & 52,5 & 30,4 & 40,6 & 55,6 & 54,5 \\
\hline 29,8 & 38,7 & 51,6 & 49,6 & 30,7 & 39,6 & 51,9 & 50,4 \\
\hline 28,3 & 34,8 & 51,2 & 50 & 29,8 & 35,2 & 52,2 & 51,2 \\
\hline 28,7 & 36,3 & 47,6 & 47 & 29,6 & 37,2 & 50 & 49,6 \\
\hline 26,8 & 39 & 53,5 & 51,4 & 26,8 & 39,9 & 55,8 & 53,4 \\
\hline 27,1 & 40,5 & 50,1 & 48 & 28,4 & 41,4 & 51,9 & 49,6 \\
\hline 27,1 & 38,6 & 46,3 & 45,2 & 28,5 & 38,7 & 50,1 & 49,8 \\
\hline 26,4 & 38,7 & 48,1 & 46,8 & 27,5 & 39,4 & 49,5 & 48,4 \\
\hline 27,7 & 36,4 & 48,9 & 46,4 & 28,6 & 36,7 & 49,9 & 47,7 \\
\hline 23,8 & 38,9 & 42 & 41,3 & 25,6 & 39,6 & 44,4 & 44,8 \\
\hline 29,6 & 38 & 50,5 & 46,1 & 28,7 & 38,6 & 52,3 & 47,9 \\
\hline 22,9 & 37,3 & 49,5 & 49,2 & 23,2 & 38 & 50 & 52,9 \\
\hline 23,3 & 36 & 48,2 & 46,6 & 24,4 & 37 & 49,2 & 47,5 \\
\hline 25,4 & 35 & 48,4 & 47,7 & 24,7 & 35,3 & 49,9 & 49,3 \\
\hline 27,3 & 36,2 & 46,6 & 45,7 & 28,2 & 36,9 & 48,1 & 48 \\
\hline & & & & & & & \\
\hline
\end{tabular}




\begin{tabular}{c|c|c|c|c|c|c|c}
\hline \multicolumn{7}{c}{ T1 } & \multicolumn{5}{c}{ T2 } \\
\hline 1-SperpPO & 1-SperpPo & $\underline{6} . \mathrm{PP}$ & $6 . \mathrm{GoMe}$ & 1 -SperpPO & 1 -SperpPo & $\underline{6} . \mathrm{PP}$ & $6 . \mathrm{GoMe}$ \\
\hline 92,2 & 87,6 & $-96,5$ & $-89,6$ & 94,1 & 89,1 & $-98,4$ & $-89,6$ \\
\hline 81,8 & 73 & $-105,9$ & $-86,8$ & 82,6 & 73,7 & $-102,9$ & $-86,7$ \\
\hline 79,2 & 75,2 & $-102,5$ & $-87,9$ & 80,8 & 77,2 & $-99,9$ & $-88,6$ \\
\hline 81,3 & 76,9 & $-112,7$ & $-90,7$ & 83,9 & 79,2 & $-107,1$ & $-88,7$ \\
\hline 78,7 & 74,7 & $-101,2$ & $-89,4$ & 80,1 & 76,1 & $-99,3$ & $-87,5$ \\
\hline 79,8 & 76,3 & $-94,3$ & $-82,5$ & 81 & 78,3 & $-93,4$ & $-83,2$ \\
\hline 75,8 & 72,9 & $-108,7$ & $-82,1$ & 76,8 & 73,7 & $-105,5$ & $-82,1$ \\
\hline 80,1 & 76,4 & $-101,7$ & $-82,6$ & 81 & 77,4 & $-102,6$ & $-83,1$ \\
\hline 76,7 & 70,7 & $-103,6$ & $-83,8$ & 78,1 & 72 & $-103,6$ & $-81,9$ \\
\hline 75 & 71,7 & $-101,2$ & $-87,1$ & 75,5 & 72,3 & $-100,2$ & $-89,1$ \\
\hline 74,9 & 70,8 & $-103,7$ & $-86,3$ & 75,9 & 71,7 & $-105,8$ & $-88,9$ \\
\hline 81,2 & 77,9 & $-104,6$ & $-88,7$ & 83,7 & 80,7 & $-107,1$ & $-89,6$ \\
\hline 80,9 & 73,6 & $-104,6$ & $-87,8$ & 82,7 & 75,5 & $-101,9$ & $-88,2$ \\
\hline 77,8 & 75,4 & $-99,7$ & $-85,6$ & 78,4 & 75,7 & $-98,8$ & $-87,4$ \\
\hline 82 & 75,3 & $-104,6$ & $-89,3$ & 83,3 & 76,5 & $-103,1$ & $-91,9$ \\
\hline 74,3 & 70,4 & $-104,1$ & $-86,9$ & 76,9 & 73,8 & $-102,3$ & $-88,2$ \\
\hline 84,9 & 80 & $-103,2$ & $-87,7$ & 85,9 & 80,8 & $-101,9$ & $-86,2$ \\
\hline 81,6 & 76,2 & $-99,8$ & -86 & 82,6 & 77,7 & $-97,8$ & $-86,1$ \\
\hline 81,2 & 75,6 & $-103,3$ & $-84,4$ & 81,3 & 76,2 & $-102,9$ & $-85,7$ \\
\hline 76,2 & 72,3 & $-104,9$ & $-83,4$ & 77,7 & 74,4 & $-102,5$ & $-81,9$ \\
\hline 82,9 & 76,8 & -102 & -88 & 84,7 & 78,7 & $-99,2$ & $-87,3$ \\
\hline 84,1 & 77,4 & $-103,9$ & $-87,6$ & 86,7 & 79,9 & $-104,8$ & -85 \\
\hline 73,4 & 69,8 & $-107,8$ & $-88,7$ & 76,2 & 72,5 & $-104,5$ & $-84,3$ \\
\hline 76,4 & 72 & $-101,6$ & $-82,1$ & 77,7 & 72,4 & $-101,5$ & $-85,4$ \\
\hline 77,4 & 72,6 & $-104,8$ & $-90,8$ & 78,9 & 73,6 & $-107,8$ & $-91,6$ \\
\hline 73,8 & 65,9 & $-100,3$ & $-84,1$ & 74,6 & 69 & $-97,9$ & $-84,6$ \\
\hline 77,1 & 74,6 & $-108,2$ & -91 & 79,1 & 76,8 & $-102,9$ & -91 \\
\hline 83,2 & 76,3 & $-100,5$ & $-81,8$ & 85,5 & 78,2 & $-98,5$ & $-79,5$ \\
\hline 79,3 & 75,2 & -101 & $-90,1$ & 80,7 & 76,5 & $-102,1$ & -90 \\
\hline 80,4 & 76,1 & $-106,8$ & $-88,2$ & 81,7 & 77,8 & $-105,8$ & $-89,6$ \\
\hline 80,5 & 75,4 & $-104,3$ & $-90,8$ & 81,6 & 77,4 & $-99,6$ & $-92,7$ \\
\hline & & & & & & &
\end{tabular}




\begin{tabular}{|c|c|c|c|c|c|}
\hline \multicolumn{3}{|c|}{ T1 } & \multicolumn{3}{|c|}{$\mathrm{T} 2$} \\
\hline sobressaliência & relação molar & ângulo nasolabial & sobressaliência & relação molar & ângulo nasolabial \\
\hline 4,5 & 0,4 & 120,1 & 5 & 1,1 & 112 \\
\hline 8,8 & $-1,1$ & 126,1 & 8,9 & $-1,2$ & 126,9 \\
\hline 3,9 & $-0,2$ & 122,8 & 3,6 & 0,7 & 123,5 \\
\hline 4,3 & $-1,2$ & 132,7 & 4,7 & $-1,1$ & 143,3 \\
\hline 4 & $-1,7$ & 114,9 & 4 & $-3,3$ & 104,5 \\
\hline 3,5 & 0 & 100,9 & 2,6 & $-0,3$ & 99,2 \\
\hline 2,8 & $-0,6$ & 130,3 & 3,1 & $-0,8$ & 130,9 \\
\hline 3,6 & $-0,8$ & 120 & 3,5 & $-2,3$ & 103,1 \\
\hline 5,9 & $-1,6$ & 119,9 & 6 & $-1,5$ & 118 \\
\hline 3,3 & $-0,4$ & 128,3 & 3,2 & $-0,4$ & 118,9 \\
\hline 4,1 & $-1,2$ & 120,3 & 4,1 & $-1,2$ & 119,3 \\
\hline 3,2 & 0,8 & 122,6 & 2,9 & 0,3 & 122,6 \\
\hline 7,2 & 0,9 & 107,6 & 7,2 & 0,9 & 103,1 \\
\hline 2,4 & $-1,2$ & 119,5 & 2,6 & $-1,2$ & 124,7 \\
\hline 6,6 & $-0,8$ & 108,8 & 6,7 & $-0,9$ & 102,5 \\
\hline 4,8 & 1,5 & 118,5 & 3 & 0,6 & 119,3 \\
\hline 4,9 & 0 & 112,7 & 5,1 & $-0,2$ & 114,6 \\
\hline 5,3 & 0,6 & 112,9 & 4,8 & 0 & 108,7 \\
\hline 5,5 & $-0,6$ & 120,7 & 5,1 & $-0,4$ & 120,3 \\
\hline 3,8 & $-1,2$ & 122,2 & 3,3 & $-1,2$ & 130,1 \\
\hline 6,1 & 0,3 & 128,2 & 6 & 0,8 & 113,9 \\
\hline 6,7 & 0,1 & 120 & 6,7 & 0,4 & 124,3 \\
\hline 3,5 & $-0,6$ & 120,9 & 3,6 & $-1,2$ & 121,4 \\
\hline 4,4 & 0 & 127,6 & 5,3 & $-0,3$ & 115,6 \\
\hline 4,7 & 0,5 & 108,4 & 5,2 & 0,2 & 106,5 \\
\hline 7,8 & $-0,7$ & 111 & 5,5 & $-1,2$ & 108,5 \\
\hline 2,5 & 1,7 & 117,9 & 2,3 & 2,2 & 123,9 \\
\hline 6,9 & $-1,1$ & 118,1 & 7,3 & -4 & 128,5 \\
\hline 4 & 0,2 & 119,3 & 4,1 & 0,3 & 117,3 \\
\hline 4,2 & $-0,5$ & 119,4 & 3,9 & $-0,5$ & 113 \\
\hline 5 & $-0,5$ & 98,1 & 4,1 & $-1,2$ & 97,7 \\
\hline
\end{tabular}




\begin{tabular}{|c|c|c|c|}
\hline \multicolumn{2}{|c|}{$\mathrm{T} 1$} & \multicolumn{2}{|c|}{$\mathrm{T} 2$} \\
\hline Ls-PrnPog' & Li-PrnPog' & Ls-PrnPog' & Li-PrnPog \\
\hline 1,4 & 3 & 0,4 & 2,6 \\
\hline$-0,5$ & 0 & $-0,8$ & $-0,5$ \\
\hline$-0,8$ & $-1,3$ & $-2,3$ & $-2,4$ \\
\hline 1 & $-0,4$ & 1 & 1,3 \\
\hline$-2,3$ & 0,5 & $-4,1$ & $-0,9$ \\
\hline$-0,9$ & 1 & $-2,3$ & $-0,2$ \\
\hline$-3,3$ & $-2,9$ & $-3,2$ & $-2,6$ \\
\hline$-3,1$ & $-3,2$ & $-2,7$ & $-3,8$ \\
\hline$-0,8$ & $-2,6$ & $-0,2$ & $-2,2$ \\
\hline$-2,8$ & 0 & $-2,9$ & $-0,2$ \\
\hline$-3,7$ & $-2,2$ & -5 & $-4,4$ \\
\hline$-7,9$ & $-5,2$ & $-7,2$ & $-4,6$ \\
\hline 0 & 0,6 & $-1,1$ & $-0,1$ \\
\hline$-6,9$ & $-5,3$ & $-5,9$ & $-6,3$ \\
\hline-5 & $-3,6$ & $-4,3$ & -3 \\
\hline$-2,9$ & $-1,4$ & $-3,6$ & $-2,5$ \\
\hline-2 & $-0,9$ & -1 & 0,4 \\
\hline$-1,6$ & $-0,6$ & $-2,2$ & $-1,5$ \\
\hline$-2,9$ & $-3,2$ & $-3,7$ & $-4,3$ \\
\hline$-3,5$ & $-3,7$ & $-5,8$ & $-4,7$ \\
\hline$-0,7$ & $-0,3$ & 0,4 & 1 \\
\hline$-2,2$ & 0,2 & $-3,2$ & $-0,9$ \\
\hline$-3,5$ & $-3,8$ & $-1,2$ & $-1,7$ \\
\hline-3 & $-1,3$ & $-4,2$ & -3 \\
\hline$-1,6$ & $-0,7$ & 0 & 0,6 \\
\hline$-2,7$ & $-6,1$ & $-3,4$ & $-5,4$ \\
\hline$-2,5$ & $-2,3$ & $-1,5$ & $-1,7$ \\
\hline$-0,5$ & $-1,8$ & $-1,2$ & $-0,8$ \\
\hline-3 & $-1,9$ & $-0,6$ & $-2,2$ \\
\hline$-3,5$ & $-0,9$ & $-2,3$ & 1,6 \\
\hline$-0,4$ & $-1,3$ & $-1,7$ & -1 \\
\hline
\end{tabular}

